Florida International University FIU Digital Commons

\title{
The Viceroyalty of Miami: Colonial Nostalgia and the Making of an Imperial City
}

John K. Babb

Florida International University, jbabb002@fiu.edu

DOI: 10.25148 /etd.FIDC000725

Follow this and additional works at: https:// digitalcommons.fiu.edu/etd

Part of the Cultural History Commons, Latin American History Commons, and the United States History Commons

\section{Recommended Citation}

Babb, John K., "The Viceroyalty of Miami: Colonial Nostalgia and the Making of an Imperial City" (2016). FIU Electronic Theses and Dissertations. 2598.

https://digitalcommons.fiu.edu/etd/2598 


\section{FLORIDA INTERNATIONAL UNIVERSITY}

Miami, Florida

THE VICEROYALTY OF MIAMI:

COLONIAL NOSTALGIA AND THE MAKING OF AN IMPERIAL CITY

A dissertation submitted in partial fulfillment of

the requirements for the degree of

DOCTOR OF PHILOSOPHY

in

HISTORY

by

John K. Babb

2016 
To: Dean John Stack

Green School of International and Public Affairs

This dissertation, written by John K. Babb, and entitled The Viceroyalty of Miami: Colonial Nostalgia and the Making of an Imperial City, having been approved in respect to style and intellectual content, is referred to you for judgment.

We have read this dissertation and recommend that it be approved.

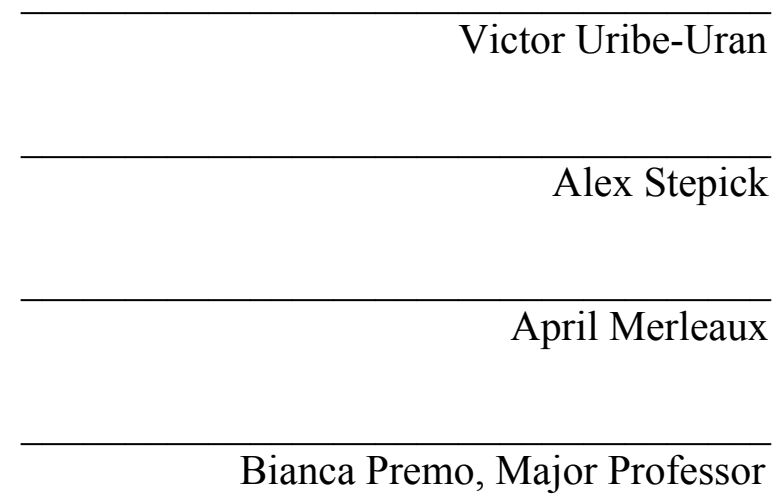

Date of Defense: July 1, 2016.

The dissertation of John K. Babb is approved.

Dean John Stack

Green School of International and Public Affairs

Andrés G. Gil

Vice President for Research and Economic Development and Dean of the University Graduate School

Florida International University, 2016 


\title{
ABSTRACT OF THE DISSERTATION
}

THE VICEROYALTY OF MIAMI:

\section{COLONIAL NOSTALGIA AND THE MAKING OF AN IMPERIAL CITY}

\author{
by \\ John K. Babb \\ Florida International University, 2016 \\ Miami, Florida \\ Professor Bianca Premo, Major Professor
}

This dissertation argues that the history of Miami is best understood as an imperial history. In a series of thematic chapters, it demonstrates how the city came into existence as a result of expansionism and how it continued to maintain imperial distinctions and hierarchies as it incorporated new people, beginning as a colonial frontier prior to the nineteenth century and becoming an imperial center of the Americas in the twentieth century.

In developing an imperial analysis of the city, "The Viceroyalty of Miami" pays particular attention to sources that elite imperialists generated. Their papers, publications, and speeches archive the leading and often loudest voices directing the city's capitalist development and its future. This focus on the elite shows both their local power over the city and their global vision for it, putting local history into dialogue with newer scholarly approaches to global urban cities.

Though imperialists worked to portray the area as untamed during the Spanish colonial period, taming nature became paramount in subsequent eras, especially during the late-nineteenth and early-twentieth century with the 
environmental transformation of south Florida. City founders intentionally introduced plants from the Americas and around the world that created an elite tropical culture in Miami, a consequence of overseas imperial acquisitions in 1898 in tropical parts of the world. Spanish revival architecture worked as the means of establishing U.S. sovereignty over a formerly contested frontier, but selfcontained suburban development inaugurated persistent problems of metropolitan management. Finally, once imperialists laid claim to the soil and the building that sat upon it, they turned to the air, making Miami a projected site of U.S. power through aviation. In light of the four substantive chapters, the Epilogue recasts our understanding of ideological migration before and after 1959 as the final stage of Miami's transformation from a colonial frontier to an imperial city. 


\section{TABLE OF CONTENTS}

CHAPTER

PAGE

INTRODUCTION .........................................................

CHAPTER I. South Florida's Unbroken Colonial Frontier.......................14

CHAPTER II. Growing a Tropical City: Naturalists, Plant Immigrants,

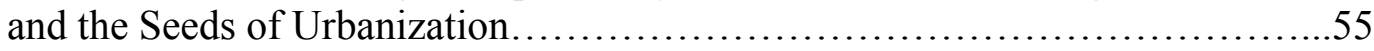

CHAPTER III. Ages-Old Materials Taking on New Forms:

The Aesthetics and Consequences of Capitalist Suburban Development.........107

CHAPTER IV. Empire's Ascent: Planes, Markets, and the

Air-merican Century ..................................................... 153

EPILOGUE. Return of the Gaze: The Imperial City Beckons its Subjects......189

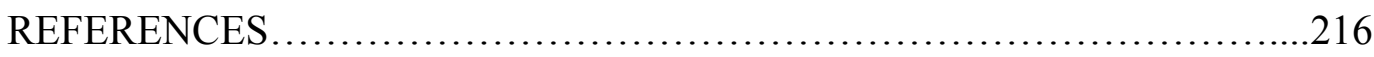

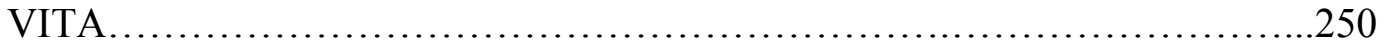




\section{LIST OF FIGURES}

FIGURE

PAGE

Figure 2.1 Unidentified storefront in Miami, dating from the 1900-1910s. Used with permission of HistoryMiami. The sign explains Henry Perrine's introduction, the fact that sisal grew wild as far north as Jupiter, and the image shows the finished cordage fibers from the sisal agave..... 70

Figure 2.2 Evidence of extensive sisal production south of Miami, dating from 1910s.

Figure 2.3 Example of Pollock Avocado from George B. Cellon's 1907 catalogue.

Figure 2.4 Example of Trapp Avocado from George B. Cellon's 1907 catalogue.

Figure 2.5 Example of Mulgoba Mango from George B. Cellon's 1907 catalogue, the origin of the Haden variety that now dominates the world's commercial market.

Figure 2.6 Leticia Southerland (left) and unnamed port inspector at Miami receiving the packaged ceibo tree from Argentina via PanAm airmail (undated, but possibly 1933)

Figure 2.7 Example of Southerland's media coverage in this January 27, 1933 edition of La razón in Buenos Aires. 98

Figure 3.1 Entrance to W.J. Bryan Estate, Miami, Florida, 1930s....

Figure 3.2 Winter Home, Mr. John H. Hanan, Miami, Florida, August Geiger, Architect.

Figure 3.3 House of Mr. Carl G. Fisher, Miami, FLA. August Geiger, Architect.

Figure 3.4 A Unique Congregational Church, Cocoanut Grove, FLA............123

Figure 3.5 Miami (New York: Montray Corporation, Oct. 1921)..............128

Figure 3.6 Douglas Entrance, Coral Gables, Florida, Dade County

Newsdealers Supply, Co., 1943, State Archives of Florida, Florida Memory....134

Figure 3.7 William A. Fishbaugh, View of a House in Hialeah, Florida, June 8, 1926, State Archives of Florida, Florida Memory. 
Figure 4.1 Frank B. Davis, Winged Aircraft Flown by Howard Gill Miami, Florida, 1911, State Archives of Florida, Florida Memory.

Figure 4.2 Seaplane in Flight, with Miami-Bimini-Nassau route listed on tail, and Columbus on the nose. January 17, 1922, State Archives of Florida,

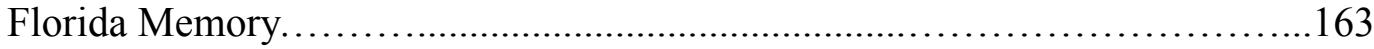

Figure 4.3 Airship Akron Leaving for Cuba with Bomber Escort, Jan. 7, 1933, State Archives of Florida, Florida Memory.....

Figure 4.4 Soldiers Performing Training Exercises on the Beach during WWII - Miami Beach, Florida, 1942-45, State Archives of Florida, Florida Memory

Figure 4.5 A Soldier Sizes Up Hawk Missiles at the Base in Everglades National Park, March 1963, Miami News Collection, HistoryMiami, 1994-370-885 185

Figure E.1 Cuban Football Team - Miami, Florida, 1928, State Archives of Florida, Florida Memory...................................................................196

Figure E.2 Fidel Castro at Teatro Flagler, Miami, November 1955.............199 


\section{INTRODUCTION}

This dissertation argues that the history of Miami is best understood as an imperial history. In a series of thematic chapters, it demonstrates how the city came into existence as a result of expansionism and how it continued to maintain imperial distinctions and hierarchies as it incorporated new people, beginning as a colonial frontier prior to the nineteenth century and becoming an imperial center of the Americas in the twentieth century. ${ }^{1}$ A long process of attempted settlement in south Florida involved shared meanings and repertoires of rule linking sixteenth-century Spanish and nineteenth-century U.S. colonial activities in the area. Though imperialists worked to portray the area as untamed during this earlier period, taming nature became paramount in subsequent eras, especially during the late-nineteenth and early-twentieth century with the environmental transformation of south Florida. City founders intentionally introduced plants from the Americas and around the world that created an elite tropical culture in Miami by the early-twentieth century, a consequence of overseas imperial acquisitions in 1898 in tropical parts of the world. During this and later decades, not only the natural but also the built environment naturalized empire in the city. Spanish revival architecture worked as the means of establishing U.S. sovereignty over a formerly contested frontier, but self-contained suburban development inaugurated persistent problems of metropolitan management. Finally, once imperialists laid claim to the soil and the building that sat upon it, they turned to

${ }^{1}$ This is based on the definition of empire in Jane Burbank and Frederick Cooper, Empires in World History: Power and the Politics of Difference (Princeton, NJ: Princeton University Press, 2011), 8. 
the air, making Miami a projected site of U.S. power through aviation. In light of the four substantive chapters, the epilogue recasts our understanding of ideological migration before and after 1959 as the final stage of Miami’s transformation from a colonial frontier to an imperial city.

\section{Key Terms}

The dissertation draws on several concepts that help highlight the imperial dimensions of Miami's past. Thinking with “the imperial," as historian Paul Kramer conceptualizes it, helps make connections over long distances of time and space, and exposes how asymmetries of power are created and maintained. In terms of the connections between imperial analysis and cities, Kramer suggests, “An imperial-urbanist scholarship would allow historians to see American cities as the hubs of imperial systems, centers of rule-making, consumption, and productive power defined both by their capacity to incorporate hinterlands of widely varying breadth - from the subregional to the global - and by struggles over the terms of that incorporation."

Building in part from Kramer's suggestion, this dissertation reveals Miami as an imperial city, a hub of imperial systems especially with respect to Latin America and the Caribbean. Viewing the city's history through the analytic of empire demonstrates how diverse activities in the city - Spanish attempts to map and name places around it; the incorporation of mango trees; the first commercial

\footnotetext{
${ }^{2}$ Paul A. Kramer, "Power and Connection: Imperial Histories of the United States in the World," Review Essay, American Historical Review, Vol. 116 (2011): 1355.
} 
flights from Miami to Cuba in the early-twentieth century - formed interrelated components of a whole story.

The title, which evokes the Spanish concept of a "viceroyalty," a parallel but subjugated kingdom in an expanding early modern empire, likewise captures the incorporative dynamics of Miami as a center of imperial power. Though the term is used ironically - Miami was never a colonial capital like Lima or Mexico City, far from it - the title intentionally invites a long distance comparison over time to the previous centers of Spanish imperial power in the Americas.

Two additional concepts that add to the imperial understanding of Miami involve the movement of people, capital, and goods between Miami and the Americas. Chapter four develops a concept related to Miami’s significance for military and commercial aviation termed "airgemony," a constellation of coercive, clandestine, and, at times, overt mechanisms of air dominance designed to limit competition and enforce acquiescence to U.S. power. The utilization by the U.S. national security state of Cuban exiles to fight the Cold War and the subsequent local and national political power they achieved through violent anticommunism is assessed in the epilogue. As a complement to historian Mae Ngai's argument that Mexican and Filipino migrant farm laborers constituted imported colonial subjects, elite Latin Americans in Miami exhibited a form of "imperial subjectivity." 3 Capital flight and ideological migration to Miami resulted not from a pursuit of democracy and freedom but from a rejection of nation and a return to the safety of empire.

\footnotetext{
${ }^{3}$ Mae Ngai, Impossible Subjects: Illegal Aliens and the Making of Modern America (Princeton, NJ: Princeton University Press, 2004), 94-95.
} 


\section{Historiography}

Three major areas of scholarship on Miami in different ways informed the research on imperialism that guides this dissertation. First, work on the history of race relations makes clear the foundational hierarchies of difference in the city that unequally restricted access to capital, land, housing, and opportunity, and had long-lasting effects on patterns of urban development. Migration scholarship clearly demonstrates the significance of the post-1959 migrations of Cubans and other Caribbean and Latin American migrants, but normally without engagement with the scholarship of race relations prior to 1959. The third area of scholarship considers the globalization of Miami and attempts to explain its status predominantly in light of geopolitical events of the 1990s. Sustained analysis of the themes considered in this dissertation renders more fully visible the continuities that span the narrated divide of 1959. Miami understood as an imperial city ultimately brings greater conceptual clarity to conflicting labels of the city as a tourist paradise, a Jim Crow city of the New South, a Cuban city, the capital of Latin America, a postmodern city, a global city, or a world city.

Some of the most important scholarship on Miami centers on the issues of race and its relationship to capitalism, which lays the groundwork for this dissertation's consideration of the tandem emergence of speculative urban development and U.S. hemispheric imperialism. The late urban historian Raymond Mohl contributed much to the study of black Bahamians and Jews in Miami as well as to better understanding the segregationist housing policies and 
racism of white Miamians. ${ }^{4}$ Melanie Shell-Weiss further explores the black Bahamian, Jewish, and pre-1960 Hispanic populations in Miami in terms of labor, including in discussions of the agricultural, construction, and service sectors. ${ }^{5}$

Nathan Connolly builds from Mohl's work to more closely consider the capitalist imperatives of often-violent continued segregation that enriched white Miamians and created a small black middle-class that profited from sustained racist housing policies. ${ }^{6}$ Chanelle Rose critically contributes to the study of civil rights in Miami through an analysis of the city's tourist industry. She shows that white Miamians' collective desire to cater to less-than-white Hispanic tourists made the policies of Jim Crow segregation difficult to sustain and black Miamians seized opportunities to challenge the color line. ${ }^{7}$

${ }^{4}$ Raymond A. Mohl, "The Origins of Miami's Liberty City," Florida Environmental and Urban Issues, Vol. 12 (Jul., 1985): 9-12; "Black Immigrants: Bahamians in Early Twentieth-Century Miami," Florida Historical Quarterly, Vol. 65, No. 3 (Jan. 1987): 271-297; Mohl, "Shadows in the Sunshine: Race and Ethnicity in Miami," Tequesta, Vol. 49 (1989): 63-80; Mohl, "Whitening Miami: Race, Housing, and Government Policy in Twentieth-Century Dade County," Florida Historical Quarterly, Vol. 79, No. 3 (Win., 2001): 319-345; Mohl, South of the South: Jewish Activists and the Civil Rights Movement in Miami, 1945 1960 (Gainesville, FL: University Press of Florida, 2004).

${ }^{5}$ Melanie Shell-Weiss, Coming to Miami: A Social History (Gainesville, FL: University Press of Florida, 2009).

${ }^{6}$ N.D.B. Connolly, A World More Concrete: Real Estate and the Remaking of Jim Crow South Florida (Chicago, IL: University of Chicago Press, 2014); see also, Connolly, "By Eminent Domain: Race and Capital in the Building of an American South Florida," (PhD diss., University of Michigan, 2008).

${ }^{7}$ Chanelle Nyree Rose, The Struggle for Black Freedom in Miami: Civil Rights and America's Tourist Paradise, 1896-1968 (Baton Rouge, LA: Louisiana State University Press, 2015); see also, Rose, "Neither Southern nor Northern: Miami, Florida and the Black Freedom Struggle in America's Tourist Paradise, 18961968," (PhD diss., University of Miami, 2007). 
In addition to these works, another strain of scholarship focuses on migration to Miami. Critically, this work has privileged the post-1959 period, emphasizing the transformative contributions of Cubans and others Caribbean and Latin American migrants. Important revisions to the standard narrative of Cubans arriving after the Revolution highlighted political and cultural links between Miami and Havana forged early on in the twentieth century. ${ }^{8}$ While also foundational to this dissertation, some of the migration scholarship occludes or undervalues continuities between post-1959 and earlier eras, especially the Jim Crow period addressed in the works discussed in the previous paragraph. ${ }^{9}$

A third line of inquiry into the city's past and present underscores Miami's status as a postmodern, global, world city. Again, in this scholarship as in the work on migration, rupture and dissonance are the major narratives. Presentist concerns in these works would make it seem that the city emerged as a chaotic urban dystopia at a recent point in time. The earlier history of the city and the

${ }^{8}$ Paula Harper, "Cuba Connections: Key West, Tampa, and Miami, 1870 to 1945," Journal of Decorative and Propaganda Arts, Vol. 22 (1996): 278-291; Francis J. Sicius, "The Miami-Havana Connection: The First Seventy-Five Years," Tequesta, Vol. 58 (1998): 4-45; Louis A. Pérez Jr., "Between Encounter and Experience: Florida in the Cuban Imagination," Florida Historical Quarterly, Vol. 82, No. 2 (Fall, 2003): 170-190; Shell-Weiss, Coming to Miami; Christina D. Abreu, Rhythms of Race: Cuban Musicians and the Making of Latino New York City and Miami, 1940-1960 (Chapel Hill, NC: University of North Carolina Press, 2015).

${ }^{9}$ Alejandro Portes and Alex Stepick, City On the Edge: The Transformation of Miami (Berkeley, CA: University of California Press, 1993); Maria Cristina Garcia, Havana USA: Cubans and Cuban Americans in South Florida, 1959-1994 (Berkeley, CA: University of California Press, 1997). 
ways that past shaped more recent developments are far from view, and the city seemingly appeared from nowhere. ${ }^{10}$

Scholarship on other imperial cities provides a guide for reconciling both the contributions of the above three lines of inquiry into the city's past and an account that takes Miami's own past seriously, as more than a backdrop for sudden, dizzying change. In particular, this dissertation seeks to position Miami within a relatively recent and growing body of scholarship that questions the neat divisions between foreign and domestic histories through imperial analyzes of urban and suburban spaces. ${ }^{11}$

\section{Sources}

In developing an imperial analysis of the city, "The Viceroyalty of Miami" pays particular attention to sources generated by elite imperialists. Their papers, publications, and speeches archive the leading and often loudest voices directing the city's capitalist development and its envisioned future. The analysis of the imperial gaze begins with Spain and the "discovery" of the New world and ends

${ }^{10}$ Saskia Sassen and Alejandro Portes, "Miami: A New Global City?" Contemporary Sociology, Vol. 22, No. 4 (Jul., 1993): 471-477; John Beverley and David Houston, "Notes on Miami," boundary 2, Vol. 23, No. 2 (Sum., 1996): 1946; Ramón Grosfoguel, "World Cities in the Caribbean: The Rise of Miami and San Juan," Review (Fernand Braudel Center), Vol. 17, No. 3 (Sum., 1994): 351 381.

${ }^{11}$ Two representative examples of this new imperial-urban scholarship are Kornel S. Chang, Pacific Connections: The Making of a U.S.-Canadian Borderlands (Berkeley, CA: University of California Press, 2012), and Andrew Friedman, Covert Capital: Landscapes of Denial and the Making of U.S. Empire in the Suburbs of Northern Virginia (Berkeley, CA: University of California Press, 2013). 
in the contemporary United States by drawing from sources as diverse as a sixteenth-century Spanish-language captivity narrative to Miami’s Spanishlanguage media of the twenty-first century.

This focus on the elite shows both their local power over the city and their global vision for it, bridging scholarship on Miami from one or the other perspective. For example, the dissertation examines the scrapbooks of an elite social club of property owners on Miami Beach in the 1920s-1930s called the Committee of 100. From the committee's records, daily life for the city's elite comes into view as does the significant role they played in promoting and securing the city as a center of commerce in the Americas. The papers of Miami Beach Garden Club President Leticia Southerland show her efforts to forge cultural links throughout the hemisphere during her expeditions to find orchid specimens to display at her annual Tropical Flower Show of the 1930s. Read together, the writings of naturalists Henry Perrine, David Fairchild, Wilson Popenoe, and Charles Torrey Simpson clarify the human intentions that shaped the city as a tropical paradise. George Merrick's personal papers chart the real estate boom of the 1920s and provide insights into the vision he and others held for Miami's suburbs as inspired by Spanish colonial precedent. The First National Bank of Miami records further document the capital accumulation of the city's leading financial institution from the early-twentieth century onward and its role in internationalizing Miami's banking sector through offshore banking in the Bahamas in the 1960s-1970s. 
Declassified documents from the Central Intelligence Agency, the Federal Bureau of Investigation, and the White House demonstrate committed efforts by state powers to control and intervene in the politics of Cuba in Miami and on the island as well as the supervision of clandestine operations conducted from Miami in Guatemala, Cuba, Nicaragua and elsewhere. Federal congressional documents cover efforts to first settle south Florida in the nineteenth century, establish tropical plant research stations in Miami, and build up and maintain the city's aviation infrastructure.

National trade journals show Miami's importance for architecture and aviation. Nationally distributed films also showed Miami's leading role as both a military and commercial aviation center in the 1930s-1940s. In addition to researched local newspapers, national news coverage in papers like the New York Times from the $1910 \mathrm{~s}$ on challenges perceptions of the city as a dwindling tourist town prior to 1959 and adds layers to elite sources that helps cut through the dominant narratives of the city's ahistorical "emergence" in the second half of the twentieth century.

\section{Organization}

The chapters are organized and analyzed by theme rather than in a strictly chronological manner, and some overlap exists chronologically between the chapters. Placing emphasis on certain themes necessarily means other categories of analysis fall from view, but in the end, the selection and organization of material was not arbitrary. Each theme illuminates a unique facet of imperialism. 
The colonial theme delineates the process of taking ownership of territory as a necessary prerequisite of imperial expansion. The tropical theme highlights how a local elite cultivated a commodified "tropics" based on a growing need for imperial control of nature on a global scale. The theme of Spanish revival architecture reflects the appropriation of previous articulations of colonial rule as a means of dominating a new, expanding urban space. The theme of aviation demonstrates the significance of flight as a technology of power to control space on a global scale.

The first chapter argues that colonialism as a category of analysis links over four hundred years of history from the first arrival of Europeans to south Florida to the late-nineteenth century arrival of wealthy North Americans. Encounters with resistant indigenous peoples and harsh, impenetrable landscapes limited the impact of colonial settlement and contributed to the understanding of the area, shared by sixteenth-century Spanish and nineteenth-century U.S. observers alike, as too difficult to inhabit and not worth the effort. South Florida persisted as a colonial frontier while the far reaches of the North American continent to the west became settled. Finally, decades after railways crossed the continent east to west, the arrival of a train, dispossession of indigenous lands, and subsequent capital investment created the conditions necessary for urban development, the final stage of colonial conquest.

Chapter two backtracks to highlight the significant career of Henry Perrine, a medical doctor from New Jersey who served as a U.S. consul in Mexico in the 1820 s and 1830 s. His interest in tropical plants and their potential market 
and medicinal values for U.S. commerce eventually led him to consider south Florida as a site of tropical plant agricultural production and research. Perrine's life and work ended when Amerindians set fire to his house, symptomatic of south Florida's frontier status, but Perrine's legacy informed later generations in the reestablishment of tropical plant research facilities in Miami at the end of the nineteenth century coordinate with the imperial acquisition of tropical territories in 1898. The over 14,000 unique tropical plants introduced to Miami's gardens by the United States Department of Agriculture resulted in a complete environmental transformation of the area from rocky pineland and grassland to tropical fruit trees and palms, the basis for the celebrated tropical culture that coalesced among Miami's elite winter residents, and still one of the most widely promoted attributes of the city.

Along with the introduced tropical landscape, chapter three considers the appropriated architectural aesthetic built in Miami, sourced predominantly from colonial Spanish America. This aesthetic naturalized dense settlement by gestures to an imagined Spanish past. Miami builders and developers bridged the gap between a new city and an imagined ancient tradition. The fantasies in concrete, though, elided certain fundamental problems of suburban civic design. Severely segregated by race and class, the self-contained model suburbs of the 1920s caused long-lasting problems of community, municipal, and county management, leading to drastic solutions of government restructuring that continue to this day.

Chapter four demonstrates the early and sustained significance of the airplane for Miami and how it connected the city to the Caribbean and Latin 
America, eventually leading to U.S. hemispheric hegemony in the Cold War era. Private, commercial, and military aviation thrived in Miami at different points throughout the twentieth century, and the city helped project and maintain U.S. air power in the region. The chapter develops the concept of "airgemony," as an analytical device to describe the ways in which U.S. military and commercial interests intended to control foreign markets and forestall potential competitors. Miami's advanced aviation infrastructure also facilitated strategies of counterairgemony, from air pirates fleeing U.S. jurisdiction to the terrorists aboard planes on $9 / 11$.

The epilogue positions the dramatic population increase in Miami of Cuban and other Latin American migrants within the context of the previous chapters. It argues that careful consideration of the themes of colonialism, the tropics, architecture, and aviation better explains why Miami became the preferred "capital of Latin America." White Miamians consistently sought to control trade with Latin America, forged cultural links with elites in the region, and provided the political space of exile for generations of disaffected Cubans and others before and after 1959. Cuban exile politics after 1959 received unprecedented federal support and attention as a consequence of the Cold War, and the local and national political power gained by exiled Cubans grew out of Cold War imperatives. In the end, the result of this long imperial history is the constructed image of elite pan-Latin culture in Miami, an image which serves the interest of U.S. imperialism, attracting capital flight from struggling national 
economies into the city and providing a counter-example to failing state policies abroad. 


\section{CHAPTER I}

\section{South Florida's Unbroken Colonial Frontier}

A deep reservoir of historical memory and meaning bridges Spain's colonial rule in the Americas with Miami's past, present, and envisioned future. This chapter excavates the layers of colonial meaning that lay beneath the city of Miami, particularly the strata left from the various imperial activities from the fifteenth to the nineteenth centuries. The history of Miami cannot be understood without first reconciling the legacy and influence of Spain, real and imagined, that later captured the romantic hearts and rational minds of U.S. imperialists. As they ascended to power in the late-nineteenth century, Americans sought context and established precedent to undergird their activities that a nostalgic understanding of Spain and Spanish America served well to provide. Miami, a capitalist curiosity at the end of the nineteenth century in search of mythical foundations, likewise gestured to the Spanish past of Florida as the means to naturalize and legitimize U.S. territorial sovereignty over North America's southeastern frontier. The lopsided Imperial War of 1898, in which Miami’s early boosters actively lobbied for participation, formalized the transfer from Spain to the United States of colonial territory on a global scale. The end of the war symbolically and materially signaled the waxing of one empire and the waning of another.

Spain initially formulated the mechanisms for establishing and maintaining sovereignty in the New World based on experiences gained in the reconquest of Iberia, a centuries-long process that culminated in the unification of the kingdoms of Aragon and Castile within a decade of Columbus's voyage. Just 
as Catholic Spain required the submission of its Muslim and Jewish enemies in the Old World, bureaucrats and missionaries at the vanguard of the New World civilizing project sought to determine and then exploit the willingness of encountered Amerindians to submit to Spain's authority. ${ }^{1}$ The accumulation of knowledge concerning Amerindian cultures paralleled the accumulation of the New World's precious metals and natural resources. New European players who entered the scene to compete with Spain's preeminence likewise privileged knowledge of the regions and its people as a source of colonial power. The countless maps and narratives produced in order to approximate the New World directly contributed to the cohesion of Western epistemology and modernity, as acquired knowledge and attempted categorizations of an alien, non-Western Other dialectically constructed an understanding of a Western Self. ${ }^{2}$ Colonialism's historical arch thus traversed the acts of translating, naming, knowing, possessing, and producing space. In material form, colonialism involved the sequential

\footnotetext{
${ }^{1}$ Irene Silverblatt, Modern Inquisitions: Peru and the Colonial Origins of the Civilized World (Durham, NC: Duke University Press, 2004); Stuart B. Schwartz, All Can Be Saved: Tolerance and Salvation in the Iberian Atlantic World (New Haven, CT: Yale University Press, 2009); Ida Altman, Emigrants and Society: Extremadura and America in the Sixteenth Century (Berkeley, CA: University of California Press, 1989).

${ }^{2}$ Fernando Coronil, "Beyond Occidentalism: Toward Nonimperial Geohistorical Categories," Cultural Anthropology Vol. 11, No. 2 (Feb. 1996): 51-87; Tzvetan Todorov, The Conquest of America: The Question of the Other, trans. by Richard Howard (Norman, OK: University of Oklahoma Press, 1999); Walter D. Mignolo, The Darker Side of the Renaissance: Literacy, Territoriality, and Colonization (Ann Arbor, MI: University of Michigan Press, 2003); Jorge Cañizares-Esguerra, How to Write the History of the New World: Histories, Epistemologies, and Identities in the Eighteenth-Century Atlantic World (Palo Alto, CA: Stanford University Press, 2002); Mark Thurner, History's Peru: The Poetics of Colonial and Postcolonial Historiography (Gainesville, FL: University Press of Florida, 2011).
} 
building of forts, missions, towns, and, finally, cities. Informed by renewed interest in classics like Saint Augustine's The City of God, Renaissance Europeans understood cities as the highpoint of civilization and the best means to guard against pagan barbarians, an understanding that found its fullest expression in the New World. ${ }^{3}$

The United States, the first nation forged out of the colonial order, rearticulated the learned behaviors and experiences of its European predecessors as it sought to affect its own territorial sovereignty. Colonialism, regardless of national provenance, was a continuous, unbroken process in the New World. It was not, as narratives devoted to one colonial project or another tend to suggest, a series of discrete, disconnected periods with different hegemonic actors devoid of a common history. History does not repeat, but it can and does accumulate. The creation of forts, towns, and then cities like Miami followed colonial repertoires of rule that linked colonial Spanish America to its nineteenth-century U.S. derivation. Rather than reading the expansion of U.S. sovereignty over Florida and other new territories as exceptional, a reading primarily attributable to

\footnotetext{
${ }^{3}$ Richard M. Morse, "A Prolegomenon to Latin American Urban History," The Hispanic American Historical Review, Vol. 52, No. 3 (Aug., 1972): 359-394; Morse, "Latin American Cities: Aspects of Function and Structure," Comparative Studies in Society and History, Vol. 4, No. 4 (July 1962): 473-493; Morse, "Some Characteristics of Latin American Urban History," The American Historical Review, Vol. 67, No. 2 (Jan., 1962): 317-338; City and Society in Colonial Latin America, edited by Louisa Schell Hoberman and Susan Migden Socolow (Albuquerque, NM: University of New Mexico Press, 1986); Richard Kagan, Urban Images of the Hispanic World, 1493-1793 (New Haven, CT: Yale University Press, 2000); Alejandra B. Osorio, Inventing Lima: Baroque Modernity in Peru's South Sea Metropolis (New York: Palgrave Macmillan, 2008).
} 
Frederick Jackson Turner, this chapter positions the long colonial history of south Florida within a broad current of scholarship that in different ways privileges the multicultural, contested terrain of the North American frontier and the American West. ${ }^{4}$ The frontier status of south Florida persisted long after the nominal transfer of territorial control from Spain to the United States. Spain's colonization of south Florida, and the assignations of meaning onto the area as a result of colonization, directly informed nineteenth-century pursuits by U.S. citizens of claimable land and the attendant violent struggles against resistant Amerindian cultures. Spanish law provided the jurisprudence for U.S. claims to land in south Florida, while several centuries worth of European narratives about south

${ }^{4}$ Frederick Jackson Turner, "The Significance of the Frontier in American History," American Historical Association, Annual Report for the Year 1893 (Washington, DC: Government Printing Office, 1894), 199-227; one of Jackson Turner's graduate students at Wisconsin, Herbert Bolton, provided an early critical expansion of the original thesis, in Bolton, "The Epic of Greater America," American Historical Review, Vol. 38, No. 3 (Apr., 1933): 448-474; more sustained critical reappraisals of the frontier thesis include Patricia Nelson Limerick, The Legacy of Conquest: The Unbroken Past of the American West (New York: W.W. Norton, 1987); Richard White, The Middle Ground: Indians, Empires, and Republics in the Great Lakes Region, 1650-1815 (Cambridge, UK: Cambridge University Press, 1991); David J. Weber, The Spanish Frontier in North America (New Haven, CT: Yale University Press, 1992); Kerwin Lee Klein, Frontiers of Historical Imagination: Narrating the European Conquest of Native America, 1890-1990 (Berkeley, CA: University of California Press, 1997); Robert V. Hine and John Mack Faragher, The American West: A New Interpretive History (New Haven, CT: Yale University Press, 2000); Alan Taylor, American Colonies: The Settling of North America (New York: Penguin, 2002), A Companion to the American West, edited by William Deverell (Maiden, MA: Blackwell, 2004); Untaming the Frontier in Anthropology, Archaeology, and History, edited by Bradley J. Parker and Lars Rodseth (Tuscon, AZ: University of Arizona Press, 2005); Stephen Aron, "Returning the West to the World," $O A H$ Magazine of History, Vol. 20, No. 2 (Mar., 2006): 53-60; a critical examination of these and other debates about the frontier can be found in Jeremy Adelman and Stephen Aron, "From Borderlands to Borders: Empires, Nation-States, and the Peoples in Between in North American History," Forum Essay, American Historical Review, Vol. 104, No. 3 (Jun., 1999): 814-841. 
Florida's barbarous Amerindian inhabitants accumulated over time to shape the conventional wisdom of a contested colonial frontier for new coming settlercolonists. Only with the capital accumulation and technological advancements of the Gilded Age did south Florida emerge from its four-centuries-old colonial condition as the instant-city of Miami. Miami's twentieth-century role in the maintenance of asymmetries of power with respect to Latin America likewise meant that the arrival of modernity to south Florida also carried with it its dark obverse, coloniality, despite the formal end of colonialism. ${ }^{5}$

\section{What's in a Name? The Long Journey from La Florida to Florida and}

\section{Mayaimi to Miami}

The earliest extant human structure in south Florida dates loosely and debatably from $500 \mathrm{BCE}$ to $900 \mathrm{CE}$. Suggestive of a ceremonial or residential form, the geometrically perfect stone circle measures 38 feet in diameter, with a series of postholes positioned between the foundational pieces that possibly once supported vertical or arched structural elements. Discovered in 1998, the sophisticated design and required labor leave open questions regarding the comparable lack of complexity in North American indigene cultures compared to Mesoamerican and Andean contemporaries. Pre-contact migratory circuits linking

\footnotetext{
${ }^{5}$ For more on the concept of coloniality, see the work of the Modernity/Coloniality/Decoloniality project at Duke University and the University of North Carolina-Chapel Hill in the collected volume Globalization and the Decolonial Option, edited by Walter D. Mignolo and Arturo Escobar (New York: Routledge, 2010), and in Coloniality at Large: Latin America and the Postcolonial Debate, edited by Mabel Moraña, Enrique Dussel, and Carlos A. Jáuregui (Durham, NC: Duke University Press, 2008).
} 
the Yucatan, Cuba, and the Florida peninsula may explain the statistical outlier, but such speculation remains merely that. ${ }^{6}$ Even if, at one time, south Florida served as a crossroads linking disparate cultures, by the time Europeans "discovered" Florida and other areas of the New World, the situation became equally new for the millions of Amerindians and Africans enslaved in the service of alien gods, kings, and meanings. ${ }^{7}$

South Florida remained a frontier of the emergent colonial order despite continued attempts to subdue its resistant inhabitants. Bartolomé de las Casas reported that several failed slave raids launched from Cuba predated the official surveys of the peninsula, first made on the east coast by Juan Ponce de León in 1513, followed by Hernando de Soto's charting of the peninsula's west coast, and Pánfilo de Narváez's raids on the peninsula in $1528 .{ }^{8}$ Targets of such slave raids constituted exemplary populations of indios bárbaros (barbaric Indians), a

\footnotetext{
${ }^{6}$ Robert S. Carr, "Majority Opinion on the Miami Circle," Archaeology, Vol. 52, No. 6 (Nov.-Dec., 1999): 10-11; the dissenting view that the circle is far less ancient is maintained by Jerald T. Milanich, "Much Ado About a Circle," Archaeology, Vol. 52, No. 5 (Sept.-Oct., 1999): 22-25; see also, Siobhan Morrissey, "A Circle Kept Unbroken: Eminent Domain Saves Rare U.S. Archaeological Site," American Bar Association Journal, Vol. 86, No. 8 (Aug., 2000): 24-25.

${ }^{7}$ See, for instance, José Rabasa, "Thinking Europe in Indian Categories, Or, 'Tell Me the Story of How I Conquered You,"' in Coloniality at Large, 43-76, and James Lockhart, The Nahuas After Conquest: A Social and Cultural History of the Indians of Central Mexico, Sixteenth through the Eighteenth Centuries (Palo Alto, CA: Stanford University Press, 1994). For the newness of the situation from the perspective of Amerindians in early colonial Virginia, see James H. Merrell, "The Indians' New World: The Catawba Experience," William and Mary Quarterly, Third Series, Vol. 41, Issue 4 (Oct., 1984): 537-565.

${ }^{8}$ Bartolomé de las Casas, "Of the Provinces of Florida," A Brief Account of the Destruction of the Indies (London: R. Hewson, 1689).
} 
category used in Spanish colonial praxis to denote those cultural groups in the New World that would not easily submit to the requirements of the Catholic king and mission system. These groups lived, as many did, on the periphery of the Spanish colonial world, violently resistant to the equally violent incursions made by colonists less familiar with the difficult terrain who often died or retreated to areas more firmly under Spanish control. Florida was not alone as a colonial frontier. Regions in Chile, the north of New Spain in what is now the U.S. southwest, and other areas persisted as peripheral frontiers into the eighteenth century and beyond. ${ }^{9}$

The creation process of knowledge about the New World and its edges unfolded, importantly, not only according to the dictates of European systems of knowing. Acts of translation incorporated Amerindian knowledge into the Western corpus even as European observers simultaneously objectified and worked to erase the origins and originators of that knowledge. ${ }^{10}$ Details of the various cultures, environs, and place names in south Florida principally came not from Ponce de León or de Soto, but from the detailed memoir of a shipwrecked creole adolescent captive-turned-ethnographer Hernando de Escalante Fontaneda. Ill-fated voyages from the Caribbean heading north to the peninsula occurred regularly because of the shallow subterranean continental shelf and reefs

\footnotetext{
${ }^{9}$ See, for example, David J. Weber's superb account of the dynamics at play on several eighteenth-century Spanish American borderlands, Bárbaros: Spaniards and Their Savages in the Age of Enlightenment (New Haven: Yale University Press, 2005), as well as Contested Ground: Frontiers on the Northern and Southern Edges of the Spanish Empire, edited by Donna J. Guy and Thomas E. Sheridan (Tuscon, AZ: University of Arizona Press, 1998).

${ }^{10}$ Mignolo, The Darker Side of the Renaissance, 199.
} 
bordering the visible peninsular landmass, with sea levels abruptly changing in depth from several hundred to less than five feet. Escalante explained that the name Martires (Martyrs) given to the barrier islands south of the mainland came from the many Spanish men who had suffered trying to navigate them. The Martyrs also appeared, at a distance, to resemble the specter of men in distress. U.S. mapmakers in the nineteenth century erroneously transliterated the westernmost of these islands, grimly named Cayo hueso (Bone Key), as Key West. The Spanish transliterated cayo for key from the Taíno parent-language word for island, cairi, found in dialects throughout the Bahamas, Cuba, and the northern Caribbean when Columbus arrived, and the name Lucayos for the Bahamas, relayed by Escalante, referred to the island-dwelling people there, whose populations completely disappeared during the sixteenth century from disease, warfare, and enslavement. ${ }^{11}$ Two towns located on the Martyrs, with possible cultural links to the Taíno, also reflected in name a definite pessimism; Guarugunbe, which Escalante translated as a pueblo de llanto (town of weeping), and Cuchiyaga, or the town where there had been suffering. ${ }^{12}$ Escalante's spatial meaning making for future colonists imbued south Florida as formidable, perilous, and resistant to colonial penetration.

\footnotetext{
${ }^{11}$ For an in-depth study of the Lucayos. see William F. Keegan, The People Who Discovered Columbus: The Prehistory of the Bahamas (Gainesville, FL: University of Florida Press, 1992).

${ }^{12}$ Memoir of Don D'Escalante Fontaneda Respecting Florida, Written in Spain, about 1575, originally translated to English by Buckingham Smith at Washington, DC (1854), revised and reprinted by the Historical Association of Southern Florida and the University of Miami (Coral Gables, FL: Parker Art Printing, 1944) 11-12.
} 
North of the Martyrs, Escalante traveled to the kingdom of Carlos ${ }^{13}$ composed of a large territorial district from the Lake of Mayaimi (Lake Okeechobee) to the southwestern extent of the peninsula. Mayaimi signified a large lake surrounded by many inhabited settlements, the principal settlement on the lake named Guacata. ${ }^{14}$ Although Escalante named many cultures and areas throughout the peninsula, including the first known reference to a large town called Tampa on the peninsula's west coast, he spent the majority of his seventeen-year captivity with Carlos, the young king who mockingly took the name as an appropriate translation of his own upon hearing of Charles $\mathrm{V}^{15}$ Escalante gave comparatively brief impressions of the smaller, linguistically distinct communities along the coast northeast, east, and southeast of the lake that he called Ais, Jeaga, and Tequesta respectively, all of which paid tribute to Carlos. Escalante did not count the Tequesta, Ais, or Jeaga dialects among the four he spoke, but he knew of another captor among the Tequesta, Don Pedro Biscaíno, in reference to his birthplace on the Spanish coast of the Bay of Biscay, who shipwrecked and became captured on the northernmost key where the river mouth settlement of the Tequesta met the bay. The names Biscayne Bay and Key

\footnotetext{
${ }^{13}$ Noted also as Callos, Calusa, or Caloosa.

14 “llamase laguna de mayaimi porques muy grande y en Redondes ai muchos pueblozuelos." Ibid., 57. Seminoles later mistranslated the meaning of Mayaimi as "sweetwater" when the city of Miami was established.

${ }^{15}$ Robert E. McNicoll, "The Caloosa Village Tequesta: A Miami of the Sixteenth Century," Tequesta, Vol. 1, No. 2, (1941): 11, footnote 3; see also, John H. Hann, Indians of Central and South Florida, 1513-1763 (Gainesville, FL: University Press of Florida, 2003).
} 
Biscayne originated from Don Pedro, who later translated for Pedro Menéndez de Aviles. Don Pedro escaped accusations of treason, managed to flee to Spain, and was named to the office of Keeper of the Swans for the court of Phillip II. The accusation of treason apparently came from Escalante along with an unnamed mulatto captor, and he jibed that the entire area would already have been conquered if Biscaíno were more of a man. Escalante warned that these communities in south Florida, skilled in archery and fishing, would never submit to the Spanish Christianizing mission. He recommended killing them all without hesitation, a cold calculation repeated centuries later in south Florida by U.S. forces in pursuit of Seminoles. ${ }^{16}$

Contested claims on the peninsula and piratical attacks from rivals to Spanish dominion in the New World resulted, in part, from the fiercely resistant inhabitants like the Tequesta and Caloosa and their ability to forestall initial settlement. News of the reinforcement provisions being sent with Jean Ribault to the French Huguenot settlement of Fort Caroline alarmed Phillip II, who ordered that Pedro Menéndez de Aviles set sail from Cuba, where he led the defeat and murder of the entire settlement. This formalized Spanish control of the peninsula under his captaincy-generalship at the presidio de San Augustín (fort of Saint Augustine) in $1565 .{ }^{17}$ Because of the prevailing winds that forced sailing vessels to exit the Caribbean to the north along its east coast and the narrow, treacherous

\footnotetext{
${ }^{16}$ Memoir, 16-22.

${ }^{17}$ John T. McGrath, The French in Early Florida: In the Eye of the Hurricane (Gainesville, FL: University of Florida Press, 2000).
} 
straits between the peninsula and the Bahamas, Florida waters contained the losses of spectacular amounts of silver and gold streaming from Upper Peru and New Spain on the way back to Cádiz. The emerging multi-imperial system built from the processes of naming and knowing initiated with individuals like Escalante, and that knowledge directly contributed to the relative success of taking possession of new and disputed lands.

Lost revenue and the potential for lost territory spurred the tighter supervision and fortification of the Florida coastline, but never on the scale or consistency seen elsewhere in Spanish America. ${ }^{18}$ A royal degree, or cédula, dated September 2, 1569, listed the names of 70 men and their sons who lived in the presidios of Carlos, Cabo de los Martires (End of the Martyrs), and Tequesta, but without a further breakdown of the number and names living at each fortified location. Many of the listed men had served in the war party that defeated the French at Saint Augustine. Among the inventoried items brought from Havana to the presidios were lead, gun powder, nails, hammers, axes, pipes of wine, water, corn, shirts, shoes, pants, salt, flour, copper, match, arcabuz (musket) powder, and iron. ${ }^{19}$ The arsenal inventory suggested that authorities took seriously Escalante's

${ }^{18}$ Paul E. Hoffman, The Spanish Crown and the Defense of the Caribbean, 15351585: Precedent, Patrimonialism, and Royal Parsimony (Baton Rouge, LA: Louisiana State University Press, 1980); Amy Turner Bushnell, The King's Coffer: Proprietors of the Spanish Florida Treasury, 1565-1702 (Gainesville, FL: University of Florida Press, 1981).

19 "Presidios de Carlos y Cabo de los Martires," 2 September 1569, made by Rodrigo Carreño, notary, and given by Pedro Menéndez Marques. Archivo General de Indios, cuaderno 941, no. 5, Cuentos de Pedro Menéndez Marques. Copied and deposited at Charlton W. Tebeau Research Library, HistoryMiami, MS Box 39. 
warning about the need to kill the unwilling Tequesta. Governor Menéndez de Aviles made some inroads with the Tequesta, however, on his frequent voyages between Saint Augustine and Cuba, and he installed two Jesuit brothers, surnamed Villareal and Rogel, as leaders of the mission effort on Biscayne Bay by 1567. Menéndez de Aviles also met with the young Caloosa leader, Carlos, on one of his trips. The two leaders agreed to terms of mutual interest that ended with Carlos giving the governor his sister, Antonia, to marry. Antonia came from an elite Tequesta family, a connection that helped forge alliances between the Tequesta and Spanish. The Tequesta, more so than the Caloosa, acceded to Spanish power and cooperated in giving safe haven to shipwrecked voyagers on Biscayne Bay, refusing to hand them over to Carlos to be held in captivity or sacrificed. The governor and Carlos, in fact, held each other in mutual distrust, a fact that led to Carlos's eventual execution at Saint Augustine by Franciscan Father Alfonso de Reynoso, the spiritual counterpart to Menéndez. ${ }^{20}$

Committed efforts to colonize south Florida failed, as the small Tequesta mission complex lay abandoned by the 1580 s. The framed meaning of south Florida as a region of resistant Amerindians, though, continued. Escalante Fonataneda's memoir remained a crucial source of information regarding the area. The most widely circulated New World literature reproduced Escalante's words in various forms, including in Richard Hakluyt's Divers Voyages Touching the Discovery of America and the Islands Adjacent (1582), Garcilaso de la Vega's La

${ }^{20}$ Robert E. McNicoll, "The Caloosa Village Tequesta: A Miami of the Sixteenth Century,” Tequesta, Vol. 1, No. 2 (1941): 13-20. 
florida del inca (1608), and Andres Gonzales Barcia's Ensayo cronológico, para la historia general de la florida (1723).

Other captivity narratives concerning south Florida furthered Escalante's view of the region and reinforced the understanding of Florida's frontier status on the margins of European colonial projects. More than a century after Escalante's captivity, Jamaican-born Quaker merchant Jonathan Dickinson published his captivity narrative at Philadelphia (1699). Dickinson, his family, and ten enslaved men, women, and children shipwrecked in the territory of the Ais, north of Biscayne Bay and the Tequesta along the coast. Three enslaved adults named Jack, Caesar, Quenza, and an enslaved child, Cajoe, died of exposure during the ordeal, in addition to Dickinson's relative, Benjamin Allen. Spanish soldiers rescued the party and gave them safe passage to Saint Augustine and then on to Charles Town (Charleston) and eventually to their original destination of Philadelphia. ${ }^{21}$ Dickinson's characterization of the cultures his party encountered as cannibalistic and inhumane reproduced and reiterated, by then, a well-known understanding of the region, but it also suggested the lack of "civilizing" achieved on the nearly two-centuries-old Spanish frontier. Another captivity narrative published after Dickinson's, written by a black servant known as Briton Hammon, likewise highlighted the cruelty and barbarity of the southeastern Florida

${ }^{21}$ Jonathan Dickinson, God's Protecting Providence, Man's Surest Help and Defence, in Times of the Greatest Difficulty, and most Eminent Danger. Evidenced in the Remarkable Deliverance of Robert Barrow, with divers other Persons, from the Devouring Waves of the Sea, amongst which they suffered Shipwrack: and also, From the cruel Devouring Jaws of the Inhumane Canibals of Florida (Philadelphia: Society of Friends, 1699). 
Amerindians, including the grim detail that he was held in a dungeon for over four years. $^{22}$

The profusion and increased diversity of voices that relayed knowledge of colonial south Florida signaled a shifting reality in which multiple imperial interests vied for the power to name and to know as they saw fit. The accumulation of resources and labor in service of those competing powers further contributed to the making of the modern world. The dynamics of colonial south Florida expose the myopia of addressing English, Dutch, Danish, or French imperial designs in the New World as autonomous from the Spanish example. All kingdoms and individuals operated as part of an interconnected system, and this system was, writes historian Eliga Gould, "fundamentally asymmetric, with Spain, as the senior and historically preeminent member, often holding the upper hand." ${ }^{, 23}$ According to historian Edmund Morgan, even the paradigmatic English colonist John Smith at Jamestown envisioned himself as a latter-day Hernando

${ }^{22}$ Breton Hammon, A Narrative of the Uncommon Sufferings, and Surprizing Deliverance of Briton Hammon, a Negro Man,--Servant to General Winslow, of Marshfield, in New-England; Who Returned to Boston, After Having Been Absent Almost Thirteen Years. Containing an Account of the Many Hardships He Underwent from the Time He Left His Master's House, in the Year 1747, to the Time of His Return to Boston.--How He Was Cast Away in the Capes of Florida;--The Horrid Cruelty and Inhuman Barbarity of the Indians in Murdering the Whole Ship's Crew;---The Manner of His Being Carry'd by Them Into Captivity. Also, an Account of His Being Confined Four Years and Seven Months in a Close Dungeon,---and the Remarkable Manner in Which He Met with His Good Old Master in London; Who Returned to New-England, a Passenger in the Same Ship (Boston: Green Russel, 1760).

${ }^{23}$ Eliga H. Gould, "Entangled Histories, Entangled Worlds: The EnglishSpeaking Atlantic as a Spanish Periphery," American Historical Review, Vol. 112, No. 3 (Jun., 2007): 765. 
Cortez, and Smith continually based his actions in Virginia on his understanding of the Spanish example. ${ }^{24}$

\section{From Knowing to Owning: The Primitive Beginnings of Civilized Capitalism}

The abundant specie of the New World fueled the market expansion of, and integration with, the Old World. ${ }^{25}$ The navigational circuits that linked Spain and the Americas depended on safe passage along Florida's coastline. The peninsula's geographical obstacles and resistant inhabitants facilitated the illicit and then sustained market entry of Spain's competitors. Enslaved populations that worked agricultural and mining enterprises also traveled in bondage along Florida's coast to unfamiliar environments and certain deaths. Florida bore witness to, and participated in, the roots (and routes) of racialized divisions of labor and the modes of production and accumulation anterior and inherent to global capitalism's development.

Piracy provided the first sustained means of primitive accumulation for the participants in the Atlantic system not subject to the Spanish and Portuguese thrones. Walter Raleigh, Francis Drake, and countless other privateers plied the many channels, bays, and islands of the Caribbean, the Florida peninsula, and

${ }^{24}$ Edmund S. Morgan, American Slavery, American Freedom: The Ordeal of Colonial Virginia (New York: W.W. Norton, 1975), 77.

25 The significance of the New World's discovery for global capitalism's development is not news. Adam Smith and Karl Marx, among many others, came to this realization. For an informed and contentious debate on the subject, see Steve J. Stern and Immanuel Wallerstein, Forum: "Feudalism, Capitalism, and The World System in the Perspective of Latin America," and Responses, American Historical Review, Vol. 93, No. 4 (Oct., 1988). 
Gulf of Mexico in search of the Spanish galleon. ${ }^{26}$ European men held no monopoly on the practice, and noted African, creole, and multiethnic pirates, as well as female pirates, made successful careers on the high seas. Pirate memoirs and fictional accounts sold wildly in the seventeenth and eighteenth centuries, with Florida often providing the exotic setting for the genre's best works, including in Captain Charles Johnson's A General History of the Pyrates (1724). According to Johnson's first-hand account, the West Indies and Florida contained the highest rate of pirate "infestation" for many reasons, including geography and the difficulty experienced by Spanish Men of War in pursuit of smaller sloops through the inlets, keys, protected harbors, and bays. The Peace of Utrecht in 1717 , among many other provisions, transferred Spain's monopoly on the slave trade, the Asiento, to England. Thus the period witnessed the dramatic rise of that nation's commerce and trade in the region, an addition to the tried and true target

${ }^{26}$ Marcus Rediker, “'Under the Banner of King Death': The Social World of Anglo-American Pirates, 1716 to 1726," William and Mary Quarterly, Vol. 38, No. 2 (Apr., 1981): 203-227; Spanish reactions and counterstrategies against piracy are found in Amy Turner Bushnell, "How to Fight a Pirate: Provincials, Royalists, and the Defense of Minor Ports during the Age of Buccaneers," Gulf Coast Historical Review, Vol, 5, No. 2 (1990): 18-35; further reading in Rediker, Between the Devil and the Deep Blue Sea: Merchant Seamen, Pirates, and the Anglo-American Maritime World, 1700-1750 (Cambridge: Cambridge University Press, 1987); Peter Linebaugh and Marcus Rediker, The Many-Headed Hydra: Sailors, Slaves, Commoners, and the Hidden History of the Revolutionary Atlantic (London: Verso, 2000); Kris Lane, Pillaging the Empire: Piracy in the Americas, 1500-1750 (Armonk, NY: M.E. Sharpe, 1998); a revisionist history of Caribbean piracy as slow to form compared to the practice in the Old World is found in Carla Gardina Pestana, "Early English Jamaica without Pirates," William and Mary Quarterly, Vol. 71, No. 3 (Jul., 2014): 321-360. 
for all buccaneers, Spanish vessels containing "the Riches of Potosi. ${ }^{27}$ From Captain Johnson came notorious names like Blackbeard as well as the origins of myths such as that of the Black Caesar, an African apprentice or freed slave of Blackbeard who spent his career along the southeastern Florida coast within the protective waters of Biscayne Bay and Key Largo.

By the eighteenth century, Spain began to lose its preeminence in the Atlantic system due to the steadier economies of scale achieved through slavedriven enterprise in English and French Caribbean and North American colonies, periodized by historian Ira Berlin as that of the plantation generations. ${ }^{28}$ Slavery as an institution accompanied Columbus at the outset, and any comparative judgments regarding the brutality or totality of slavery in any one time and place versus another misses the point. Slavery developed in the context of an Atlantic system that implicated everyone and absolved no one, except, of course, the human victims, whose frames of reference and meaning were often stolen along with their bodies. The descendants of every participant nation share in the

${ }^{27}$ Captain Charles Johnson, A General History of the Pyrates, from Their Rise and Settlement in the Island of Providence, to the present Time, (London: T. Warner, 1724) 25-28. Another significant work of pirate literature, first published in Dutch and subsequently in English, German, and Spanish translations, is A.O. Exquemelin, The Buccaneers of America (1678), which followed the exploits of Henry Morgan at Panama.

${ }^{28}$ Ira Berlin, Many Thousands Gone: The First Two Centuries of Slavery in North America (Cambridge, MA: Harvard University Press, 1998). 
ignominy of a Black Legend, which was discursively constructed by rivals and critics as the moral bankruptcy of Spain alone. ${ }^{29}$

Having said that, Spanish Florida never developed into a slave society comparable to South Carolina, Virginia, Jamaica, Saint-Domingue, Cuba, or Brazil, and its persistence as a frontier territory composed of free and enslaved blacks, missionized and "barbaric" Amerindians, and Europeans of varying stations provided the spaces outside the strictures of plantation life sought and enjoyed by the escaped and disenfranchised. Historian Jane Landers cogently argues that the formal legal personhood recognized in enslaved and free alike distinguished Spanish Florida from its northern neighbors and their demands for written proof of freedom at every turn, an impossible requirement for most to meet. The category of esclavos reales (royal slaves) did not exist in English racial labor hierarchies, but royal slaves in Spanish colonies, including in Florida, enjoyed a relative degree of autonomy because they were the property of the crown itself as opposed to an individual, which conferred definite legal protections from abuse, and even allowed for the purchase and sale of property in the form of land as well as enslaved men and women of their own. ${ }^{30}$ From the

${ }^{29}$ Gabriel B. Paquette, Enlightenment, Governance, and Reform in Spain and its Empire, 1759-1808 (London: Palgrave Macmillan, 2008) 46-54; CañizaresEsguerra, How to Write the History of the New World, 132-134; see also, Rereading the Black Legend: The Discourses of Religious and Racial Difference in the Renaissance Empires, edited by Margaret R. Greer, Walter D. Mignolo, and Maureen Quilligan (Chicago: University of Chicago Press, 2007).

${ }^{30}$ Jane G. Landers, Black Society in Spanish Florida (Urbana, IL: University of Illinois Press, 1999), Landers, "Black Community and Culture in the Southeastern Borderlands," Journal of the Early Republic, Vol. 18, No. 1 (Spr., 1998): 117134; see also María Elena Díaz, The Virgin, the King, and the Royal Slaves of El 
perspective of North American slaveholders, the close proximity of Florida's frontier and Spain's implicit acceptance of slaves' legal personhood threatened the security of their private, human property, and so they justified violations of Spain's territorial sovereignty over Florida as acts of protecting private property.

The English invasion and temporary occupation of Havana and permanent occupation of Saint Augustine in 1763 coincided with the end of the Seven Years' War. Previous incursions into Spanish domains never resulted in a transfer of territorial control. It took centuries of pirating and then human slavery for England to succeed in its ventures, and the accumulated capital finally contributed to its ability to challenge Iberian preeminence. Because of the known differences between legal systems, hundreds of black and Amerindian refugees fled from Florida to Cuba with the Spanish clerical and political class when England assumed formal control of the peninsula. ${ }^{31}$

The twenty-one years of English rule from 1763 to 1784 most importantly resulted in the peninsula's division into two districts; West Florida, composed of the coastal areas from the Mississippi River north of New Orleans east to the Apalachicola River, and East Florida, which constituted the majority of the peninsular landmass that became the U.S. state of Florida. Vain attempts to

Cobre: Negotiating Freedom in Colonial Cuba, 1670-1780 (Palo Alto, CA: Stanford University Press, 2001).

${ }^{31}$ Jane Landers, "An Eighteenth-Century Community in Exile: The 'Floridanos' in Cuba," New West Indian Guide, Vol. 70, No. 1/2 (1996): 39-58; John Jay TePaske, The Governorship of Spanish Florida, 1700-1763 (Durham, NC: Duke University Press, 1963); for the militarization of Cuba partially in response to the loss of Florida, see Sherry Johnson, The Social Transformation of EighteenthCentury Cuba (Gainesville, FL: University Press of Florida, 2001). 
repopulate the peninsula after the exodus of Amerindians and Spaniards to Cuba included an unrealized colonization scheme for Biscayne Bay in 1773, known as the Cape Florida Society, in reference to the northernmost key, Cape Florida, also called Key Biscayne. After William Gerard De Brahm completed his survey of East Florida's coast in his role as Surveyor-General for the Southern District of North America, three large land tracts along the mainland coast of Biscayne Bay were granted, from north to south, to John Augustus Ernst (20,000 acres), Samuel Touchett (20,000 acres), and the Earl of Dartmouth William Legge (40,000 acres). Plans for colonization included the recruitment of French Protestant families to rent the land from the Earl in perpetuity, with the goal of growing any variety of commodities available, including indigo, cotton, silk, and wine. Bylaws outlined a measure of equality for all white subscribers to the society and free parcels of land were intended to attract willing participants from varying social classes, and any enslaved purchased to work the land had to be provided adequate housing and would be shared as communal property. Swiss promoters with links to De Brahm also recruited willing Swiss, Scottish, Irish, and English colonists, but unproductive correspondence between De Brahm and society members dissuaded the latter of the inclination, with plans ceased by the end of 1773 and the grants rescinded to Spain along with the Floridas as part of the 1783 Treaties of Paris and Versailles, which marked the formal end of the American Revolution. ${ }^{32}$

${ }^{32}$ Roland E. Chardon, "The Cape Florida Society of 1773," Tequesta, Vol. 35 (1975): 1-36. 
Over the course of the following century that saw Florida's territorial control change hands three times, speculative, unrealized claims on the land that would become the city of Miami came and went before it received the attention and capital investment required to transform a colonial frontier into a burgeoning metropolis.

\section{Sovereignty at a Price: Speculative Claims and Capital's Late Conquest of}

\section{South Florida}

The accumulated knowledge of several centuries and the accumulated capital from exploitative labor regimes accelerated the expansion of colonial settlements further into previously contested frontier spaces like Florida. Territorial acquisition by treaty naturalized U.S. sovereignty over disparate lands in the minds of policy makers and on the maps that guided them. On the ground, the many cultures already inhabiting lands understood as their own experienced the violent force of that naturalizing process; the same violence thrust upon Caribbean, Andean, and Mesoamerican cultures. ${ }^{33}$ From Florida to the Great Lakes and from Puerto Rico to the Philippines, "westward expansion" is, in truth, the colonial history of the United States. The North American frontier and its nineteenth-century pioneers, then, shared a history and common terrain of meaningful experience with sixteenth-century conquistadors and missionaries. The objectification and violent struggle against cultures constructed as the Other in pursuit of a continent-wide usurpation of land and resources manifested a

${ }^{33}$ Mark Rifkin, Manifesting America: The Imperial Construction of U.S. National Space (New York: Oxford University Press, 2012). 
"destiny" already known to the Spanish American world for centuries. From the late-eighteenth century onward, the increased frequency of speculative claims to land in south Florida and the continued confrontation and warfare waged against Amerindian occupants of the land intensified, but did not replace, outmode, or materially change the mechanisms and means of colonial rule.

The successful revolution of the thirteen North American colonies against England brought the newly minted nation into conflict with its wartime ally Spain over the territorial limits of West Florida and the other southeastern territory previously under English control, as well as to determine the limits and extent of commerce along the Mississippi River. The 1795 Treaty of Friendship, Limits, and Navigation between Spain and the United States, also known as Pinckney's Treaty or the Treaty of San Lorenzo de El Escorial, became the first of several significant treaties between the two imperial nations regarding territorial boundaries. ${ }^{34}$

Despite the friendliness implied in the 1795 treaty, West Florida remained a disputed territory between Spain and the U.S. until rebels from Georgia territory invaded the Spanish garrison at Baton Rouge and declared an independent republic in 1810. As a political gesture to Spain, President James Madison refused to recognize the republic and instead argued that the territory be included as part of the 1803 Louisiana Purchase. The coastal region south of Baton Rouge

${ }^{34}$ Treaties and other International Acts of the United States of America, edited by Hunter Miller, Vol. 2, Doc. 1-40: 1776-1818 (Washington, DC: Government Printing Office, 1931). See also Samuel Flagg Bemis, Pinckney's Treaty: America's Advantage from Europe's Distress, 1783-1800 (Westport, CT: Praeger, 1960). 
remained as part of Spanish West Florida until 1813, when James Wilkinson invaded Mobile and forced the surrender of the resource-strapped Spanish garrison commander Simon de Herrera. ${ }^{35}$ The Second Spanish Period was characterized by a lack of funding and resources to defend against encroachments from the north, especially after Napoleon invaded the Iberian Peninsula in 1808 and placed his brother Joseph on the throne, which he held until 1814.

Apologists for violations of Spanish sovereignty over Florida repeatedly used the lack of Spain's control as the justifiable pretext for invasion. Negotiations pertinent to Florida's future had already begun at Washington in 1810 between Spain's Luis de Onís and John Quincy Adams. Onís repeatedly lobbied to anyone who would listen that the sale of Louisiana from France to the United States was invalid because of Napoleon's violation of the San Ildefonso Treaty between Spain and France. U.S. citizens held a lengthy list of complaints of property damage against Spain dating from at least 1802, mostly in the form of lost human property. The terms of the negotiations between Adams and Onís then regarded Florida, property reimbursements, and western territory. In pursuit of runaway slaves who escaped to Florida to seek protection with the Seminoles, who also were attempting to escape U.S. forces in Georgia, Andrew Jackson invaded in 1818 and captured Fort Barrancas at Pensacola. Ferdinand VII, restored to the Spanish throne, suspended negotiations when he heard of Jackson's illegal acts. President James Monroe publicly condemned Jackson in view of the political fallout it engendered, but Quincy Adams applauded Jackson

${ }^{35}$ J.C.A. Stagg, Borderlines in Borderlands: James Madison and the SpanishAmerican Frontier, 1776-1821 (New Haven, CT: Yale University Press, 2009). 
and vigorously defended him. In a collection of Jackson's letters written during the conflict, no doubt released to quiet U.S.-Spanish relations, Quincy Adams explained that the continued hostilities of "Negro banditti" and Seminoles in Florida in supposed collusion with English agitators, and Spain's inability to stop them, warranted Jackson's intervention. Jackson's motives were founded in the "purest patriotism" of self-defense. The existence of a "Negro Fort" proved, in his mind, that Florida was a derelict territory "open to the occupancy of every enemy civilized and savage, of the United States, and serving no other earthly purpose than as a post of annoyance to them." Spain had to either "place a force in Florida adequate to the protection of her engagements, or cede to the United States a province, of which she retains nothing but the nominal possession." ${ }^{36}$ How a U.S. province nominally under Spanish possession would function did not receive explicit mention, but the hypothetical arrangement reflected, in microcosm, the overlapping and reinforcing colonial histories of the Americas. In defense of the continued use and secured ownership of enslaved labor, Jackson, Quincy Adams, and others defended the right to continued colonial expansion, a right bestowed to them by Spain and a right in need of protection within U.S. and Spanish jurisdictions.

The Transcontinental Treaty, later known as the Adams-Onís Treaty, eventually received the backing of the two sides and was signed in 1819 . The

${ }^{36}$ Memoirs of General Andrew Jackson, together with the Letter of Mr. Secretary Adams, in Vindication of the Execution of Arbuthnot and Ambrister, and the other Public Acts of Gen. Jackson, in Florida, (Bridgeton, N.J.: Simeon Sigfried, 1824) 29-33; see also, James W. Covington, "Migration of the Seminoles into Florida, 1700-1820,” Florida Historical Quarterly, Vol. 46, No. 4 (Apr., 1968): 340-357. 
United States agreed to repay its own citizens for claims against Spain up to $\$ 5$ million (thus, gave no direct payment to Spain), while Spain gave up all claims to territory east of the Mississippi. Spain received a guaranteed northern boundary for Texas, which had never been previously determined, south of the Rio Colorado but north of the Rio Grande, based on a survey done by a mission priest from New Spain, José Antonio Pichardo, a survey later disputed by U.S. invaders. The United States also received its first definite claim to access of the Pacific Ocean in Oregon, hence the transcontinental component of the treaty name. ${ }^{37}$ Adams, in a diary entry dated February 22, 1819, summarized the significance: "The acquisition of the Floridas has long been an object of earnest desire to this country. The acknowledgment of a definite line of boundary to the South Sea [Pacific Ocean] forms a great epoch in our history. ${ }^{, 38}$

Manifest destiny from sea to shining sea first required a "definite" acknowledgement of U.S. power from its imperial predecessor in Spain. Quincy Adams rendered the acquisition of Florida as explicitly bound up with this "great

${ }^{37}$ Philip Coolidge Brooks, "Spain's Farewell to Louisiana, 1803-1821," The Mississippi Valley Historical Review, Vol. 27, No. 1 (Jun., 1940): 27-41; Brooks, Diplomacy and the Borderlands: The Adams-Onis Treaty of 1819 (Berkeley, CA: University of California Press, 1939); Brooks and Felix Calleja, "Pichardo's Treatise and the Adams-Onís Treaty," Hispanic American Historical Review, Vol. 15, No. 1 (Feb., 1935): 94-99.

${ }^{38}$ Quoted in Frederick Cubberly, "John Quincy Adams and Florida," Florida Historical Quarterly, Vol. 5, No. 2 (Oct., 1926): 92. Don Luis de Onís likewise memorialized his efforts in his Memoir upon the Negotiations between Spain and the United States, which led to the Treaty of 1819, Translated by Tobias Watkins (Washington, DC: E. De Kraft, 1821). De Onís maintained friendly correspondence with Thomas Jefferson, digitally available through the Library of Congress, and those letters are worth reading. 
epoch" of U.S. history. The Adam-Onís Treaty provided Quincy Adams with crucial experience as the author of U.S. expansion. Within a year of the treaty's 1822 finalization, President James Monroe gave his seventh annual message to Congress. In what became the policy guide to justify U.S. imperialism in Latin America, and most likely written by Quincy Adams, Monroe reminded all Americans that it was from Spain that "we derive our origin.", ${ }^{39}$ The Monroe Doctrine can, in fact, be read as a retooled version of Quincy Adams's defense of Jackson invading Florida. Spanish American independence movements could not be stopped because Spain lacked adequate forces to defend its interests, the same conclusion reached in the case of Florida that required Jackson's intervention. Attempts to protect private property on the southeastern frontier resulted in a cohesive doctrine of intervention throughout the hemisphere. U.S. imperialism and the mechanisms of territorial expansion took shape, then, in the act of acquiring Florida. Appropriately, the southeastern extreme of the peninsula would later become the city of utmost strategic importance to U.S. imperial interests in the Americas.

Florida's acquisition by the United States did not foreclose Spain's colonial precedent previously established on the peninsula. Part of the treaty stipulations of Adams-Onís involved Spain agreeing to not grant any more titles to land in East Florida after 1818. The U.S. Congress created a land commission

${ }^{39}$ President Monroe's Message at the Commencement of the First Session of the Eighteenth Congress, 2 December 1823; see also, Worthington Chauncey Ford, John Quincy Adams: His Connection with the Monroe Doctrine (Cambridge, MA: J. Wilson, 1902), and Jay Sexton, The Monroe Doctrine: Empire and Nation in Nineteenth-Century America (New York: Hill and Wang, 2011). 
of three members, appointed by the president, to adjudicate any claims to land made under Spanish jurisdiction, as well as to give new titles to land if none previously existed. Alexander Hamilton, second son of the Federalist leader, served as one of the three commissioners appointed by James Monroe. Hamilton made the case in 1822 that claims to land should be dealt with by two separate commissions for East and West Florida to expedite the process. He estimated that as many as 1,200 Spanish claims and 500 British claims required the commission's attention. Hamilton joined Davis Floyd and William W. Blair in Saint Augustine by 1823 to begin the work for East Florida claims. The difficulty of the work resided in the fact that no clear Spanish code was apparent to judge the validity of claims. Hamilton eventually persuaded the commission that the Laws of the Indies (book 4, title 12) provided the most appropriate jurisprudence. Additional difficulties arose from the fact that, after 1815, the final Spanish governor of East Florida, José Coppinger, began a "jubilee” distribution of land titles in anticipation of Spain losing the territory to the United States. Millions of acres were promised in the interim, the first of many speculative real estate bonanzas in Florida. Land titles and other documents, again counter the terms of Adams-Onís, steadily left Saint Augustine for Havana aboard Spanish vessels, which prompted Andrew Jackson, awarded the territory's inaugural governorship for his unscrupulous efforts, to confiscate the remaining documents.

Disagreements then proceeded between the appointed keeper of the archives, William Reynolds, and Hamilton over their safety and security. Hamilton resigned from his post due to the mounting frustrations, but the Supreme Court, in 
a series of cases throughout the 1830s-40s, sided with Hamilton and agreed that the Laws of the Indies offered the appropriate jurisprudence for the claims. ${ }^{40}$ The Supreme Court retained the jurisprudence of the Laws of the Indies in considering claims to property ranging from the mid-nineteenth century southwest to the colonial Philippines of $1910 .{ }^{41}$ Hamilton, in attempting to do his job on a lowly territorial frontier, ended up providing the precedent for a globe-spanning U.S. imperial regime, a precedent established and passed down by its imperial predecessor in Spain.

One of the jubilee land grants made before Spain transferred control to the United States covered Biscayne Bay and the Miami River. In 1813, Juan Xavier de Arrambide y Gorecoechea received 90,000 acres, a massive grant, beginning at the New River (Fort Lauderdale) south to Key Largo that he intended to use as a sawmill and resin production facility. Arrambide left his native Cuba and took up residence northwest of Key Biscayne on the north side of the Miami River to pursue these ends, but he soon left because of the hostile Amerindians and Black Seminoles (marooned former enslaved or their descendants). Arrambide sold his grant to Archibald Clark in 1817, but a Joseph

${ }^{40}$ George C. Whatley and Sylvia Cook, "The East Florida Land Commission: A Study in Frustration," Florida Historical Quarterly, Vol. 50, No. 1 (Jun., 1971): 39-52; see also, Sidney F. Ansbacher and Joe Knetsch, "Negotiating the Maze: Tracing Historical Title Claims in Spanish Land Grants and Swamp and Overflowed Lands Act," Journal of Land Use \& Environmental Law, Vol. 17, No. 2 (Spr., 2002): 351-373.

${ }^{41}$ For California, see United States v. Ritchie (1854), and for the Philippines, see Tiglao v. Insular Government of the Philippine Islands (1910). For New Mexico, see Laura E. Gomez, Manifest Destinies: The Making of the Mexican American Race (New York: New York University Press, 2008). 
Delespine made a second claim for the same land. Confusingly, the land commission at Saint Augustine approved both claims. Clark never petitioned the Superior Court of East Florida for validation, the normal procedure for disputed claims, and so his claim became null and void. Delespine did petition the court only after the five-year statute of limitations had elapsed. The court still approved his claim, but the United States district attorney appealed, and the Supreme Court found the claim to be invalid because Havana never had authority to grant so much land per the Laws of the Indies, the land had not been properly surveyed, and Delespine did not petition in time. The land reverted to the federal domain as a result, which reopened the area for new claims. ${ }^{42}$ U.S. territorial control and the jurisprudence of private property rights built upon Spanish precedent, and that precedent either confirmed or denied legitimate access to lands in south Florida and elsewhere.

Seminole resistance to expansive designs on Florida proved the major obstacle to territorial settlement, the same problem that faced Spanish missions in the previous centuries with respect to the Tequesta, Caloosa, and other cultures. Many of those groups left to Cuba to remain under Spanish jurisdiction, both after 1763 and again after 1819, but reports of "Spanish Indians" in south Florida lingered on into the twentieth century. ${ }^{43}$ Seminoles constituted the remnants of

${ }^{42}$ Henry S. Marks, “A Forgotten Spanish Land Grant in South Florida," Tequesta, Vol. 20 (1960): 51-55. See also United States v. Heirs of Joseph Delespine (1838).

${ }^{43}$ William C. Sturtevant, "Chakaika and the 'Spanish Indians': Documentary Sources Compared with Seminole Tradition,” Tequesta, Vol. 13 (1953): 35-73. 
Cherokee, Chactaw, Creek and other culture groups that refused U.S. removal attempts and initiated the first of the Seminole Wars, joined by bands of marooned former slaves from Georgia and elsewhere that sought refuge in Florida. In 1835, the second attempted removal aimed to eliminate those remaining communities, with the majority living around Tampa. Only about onethird of the leaders agreed to the terms of the second removal, which resulted in the second and most brutal of the Seminole Wars. The difficult terrain of the sawgrass wetlands and mangrove hammocks of south Florida provided Seminoles with the bases of attack and protection to ward off the U.S. Army and Navy. ${ }^{44}$

One of the most notorious strategies employed by U.S. forces involved the use of Cuban bloodhounds, bred to capture runaway slaves on the island and purchased from slaveholders there, to pursue Seminoles in the foreboding country. Such savage tactics make clear the shared strategies of rule that linked Spanish and U.S. colonial projects. Illustrations of Seminole women being eaten by the bloodhounds scandalized the nation, and opponents of Zachary Taylor's 1848 presidential campaign relived those gruesome images to highlight his significant role in the conflict. ${ }^{45}$ Several notable U.S. military men died as a result of the superior ambush tactics used by the Seminoles, including Major Francis Langhorne Dade at Tampa in 1835 (Dade County being his namesake). By 1836, all of the structures in southeast Florida had been burned down and many white

\footnotetext{
${ }^{44}$ James W. Covington, "Migration of the Seminoles into Florida, 1700-1820," Florida Historical Quarterly, Vol. 46, No. 4 (Apr., 1968): 340-357.

${ }^{45}$ See, for example, William Lloyd Garrison and H.C. Wright, "The Bloodhound Candidate," The Liberator, 30 June 1848, Issue 26.
} 
settlers killed. Fort Dallas, erected near the mouth of the Miami River by a gang of enslaved men under the direction of land speculator Richard Fitzpatrick, proved a feeble base of support for the struggling U.S. forces and was overrun by the Seminoles, and the lighthouse on Key Biscayne, the Cape Florida Light commissioned in 1825, was destroyed. By 1842, the defeated U.S. forces retired from the fight and submitted to allow the remaining Seminoles to stay in southwestern Florida, the former domain of the Caloosa and Carlos, on an informal reservation. ${ }^{46}$ Many of the veterans who saw the loss of the Seminole Wars would find success in the Mexican-American War of 1848. The strategies of encounter and warfare against Amerindians on territorial frontiers like Florida framed and informed other encounters and wars against nations like Mexico and cultures in the West like the Lakota or Comanche. The meaningful articulation and forceful acquisition of one borderland, then, resulted from earlier articulations on previously established frontiers.

Historical memories gleaned from the Seminole Wars proved wideranging and long lasting. The radical implications of supposedly uncivilized, barbaric Amerindians defeating an organized U.S. armed force inspired a young Friedrich Engels, in a letter to a friend, to write a three-verse poem, entitled Florida, written from the perspectives of the Spirit of the Earth, a Seminole, and a White Man, with the latter's death filling the poignant final line. ${ }^{47}$ As increasingly

\footnotetext{
${ }^{46}$ Nathan D. Shappee, "Fort Dallas and the Naval Depot on Key Biscayne, 18361926," Tequesta, Vol. 21 (1961): 13-40.

${ }^{47}$ Friedrich Engels to Friedrich Graeber, "Florida," 20 January 1839, Bremen, Germany, accessible via Marxist Internet Archive.
} 
numerous and hostile white settlers forced Black Seminoles out of Key Biscayne to the Bahamas, they set up the conditions that made it possible to memorialize Key Biscayne, in the twentieth century, as the southernmost port of exit on the Underground Railroad. ${ }^{48}$ Complicated and contradictory as it appeared, Florida was both a slave state (by 1845) and a frontier space where autonomous communities of Amerindians and emancipated blacks maintained their freedom. After the war, such contradictions remained, as northern progressive whites like Harriet Beecher Stowe settled in Florida to initiate programs of black education and interracial harmony because of its supposedly less extreme racial divisions. ${ }^{49}$ The realities of a contested frontier, the same realities that faced Spain in its attempted administration of the peninsula, persisted long after the formal acquisition of the territory by the United States.

The duty of warfare against the Seminoles fell to private citizens with the Armed Occupation Act of 1842 passed by the U.S. Congress. The act intended to populate the frontier portions of East Florida not yet settled, which focused on Biscayne Bay and more generally the south of the peninsula. As was the case with the Spanish mission of Tequesta in the sixteenth century, the act stressed the need to bear arms to fight aggressive Seminoles. The construction of new forts throughout the territory likewise reproduced strategies of Spanish rule, many of

\footnotetext{
${ }^{48}$ Rosalyn Howard, Black Seminoles in the Bahamas (Gainesville, FL: University of Florida Press, 2002).

${ }^{49}$ Harriet Beecher Stowe, Palmetto-leaves (Boston: J.R. Osgood and Company, 1873). For Florida's admission as a slave state, see Franklin A. Doty, "Florida, Iowa, and the National 'Balance of Power,' 1845," Florida Historical Quarterly, Vol. 35, No. 1 (Jul., 1956): 30-59.
} 
which were literally built on the sites of crumbling presidios. In the absence of effective occupancy, the network of lighthouses found all along the eastern seaboard and throughout the Gulf of Mexico gave the impression of control in sparsely occupied lands. Cape Florida Light was one of the earliest commissioned by the federal government because, again as we have already seen, the navigational channels were so treacherous between the Gulf of Mexico, the east coast of the peninsula, and the Bahamas. The thriving wreckage industry based at Key West declined precipitously with the construction of lighthouses, and damages done to lighthouses often involved disgruntled wreckers. Fort Dallas and the Cape Florida Light were rebuilt after the temporary cessation of the Seminole conflicts. The U.S. Navy maintained the lighthouse despite Florida's participation in the Civil War as a member of the Confederacy, and one attack on the structure during the war came from confederate sympathizers. South Florida witnessed little other action during the war and afterwards, and the fort fell into disrepair. The only real development resultant from the Armed Occupation Act involved the uptick in the production of an otherwise toxic plant called arrowroot or coontie, first cultivated by Black Seminoles and learned by the fledgling white settlers in the area primarily as a means of survival. ${ }^{50}$

Several claimants bought and sold the Fort Dallas property before being purchased by Julia Tuttle, who had intentions of homesteading in south Florida, motivated in part by the Homestead Act of 1862 and its generous acreage

${ }^{50}$ Nathan D. Shappee, "Fort Dallas and the Naval Depot on Key Biscayne, 18361926," Tequesta, Vol. 21 (1961): 13-40; Joe Knetsch and Paul S. George, "A Problematical Law: The Armed Occupation Act of 1842 and Its Impact on Southeast Florida," Tequesta, Vol. 53 (1993): 63-80. 
provisions. Julia Tuttle's father, Ephraim Sturtevant, homesteaded on Biscayne Bay before her in the 1870s and became a leading figure in the state's short-lived Reconstruction policies. Tuttle decided to permanently move to south Florida after her husband's death in 1886 . Her husband's father partnered the merchant and grain commission firm Hewitt \& Tuttle in Cleveland that first hired a young John D. Rockefelller. Rockefeller and Julia Tuttle shared a long-standing friendship, both being congregants of the Euclid Avenue Baptist Church in Cleveland. As Standard Oil greatly expanded in the 1860s and 1870s, Tuttle remained close to Rockefeller. When she decided to permanently move to Florida, she wrote to Rockefeller and petitioned him to put in a good word with his former Standard Oil cofounder, Henry Flagler, whose resort and railroad venture had by the 1880s built tracks and luxurious hotels on the northeast coast of Florida at Jacksonville and Saint Augustine. ${ }^{51}$

Convinced that Florida's east coast lacked only his benefaction in order to develop, Flagler reveled in the Spanish past of the peninsula, naming his flagship resort at Saint Augustine the Ponce de Leon Hotel (now Flagler College), designed in a Spanish Renaissance style reminiscent of Andalusia. Tuttle likewise celebrated the Spanish legacy in her rebuilt Fort Dallas estate complete with decorative Spanish floor tiles she had recovered from a wrecked vessel off Biscayne Bay. The Cleveland connection, which included former Clevelanders William and Mary Brickell whose property lay opposite Julia Tuttle's Fort Dallas property on the river mouth's south bank, convergent with harsh freezes in the

${ }^{51}$ Edward W. Akin, "The Cleveland Connection: Revelations from the John D. Rockefeller - Julia D. Tuttle Correspondence," Tequesta, Vol. 42 (1982): 57-61. 
winter of 1894-95 that ruined much of the state's citrus crop, produced the founding myth of the city of Miami. A persistent advocate to extend Flagler's Florida East Coast (FEC) Railroad to Biscayne Bay, Tuttle sent the magnate a crate of orange blossoms and fruit to prove that the settlement's lower latitude dulled the bite of the northern frosts, a proposal further induced by her promise of choice lots for development to be donated by herself and the Brickells for a new resort and train depot. Flagler established Palm Beach in the north of Dade County with the Royal Poinciana Hotel by 1894, so the extension south to Miami did not overextend the enterprise too much. ${ }^{52}$

Tuttle and Flagler also both understood the locational significance of Biscayne Bay and its strategic position to emerging Latin American markets. The 1905 U.S. takeover of the failed French canal project in Panama would urge Flagler to extend the railroad from Miami to Key West. The arrival of the railroad to Biscayne Bay in 1896 prompted the formal incorporation of Miami as a city, with 162 of the 400 signees for incorporation being men of color. Not suggestive of any measure of racial camaraderie or equality, the black voters in Miami went to the polls, under threat of job loss or worse, to support their railroad bosses, in particular the soon-to-be mayor of the city John Sewell, who made a name for himself as a gang labor leader that supported Flagler's rail and hotel march to Miami. $^{53}$

\footnotetext{
${ }^{52}$ Ruby Leach Carson, “Miami: 1896-1900,” Tequesta, Vol. 16 (1956): 3-13.

${ }^{53}$ N.D.B. Connolly, A World More Concrete: Real Estate and the Remaking of Jim Crow South Florida (Chicago: University of Chicago Press, 2014), 20-21.
} 
The FEC and its interested parties immediately clashed with the "antis" or anti-corporate founders of the city. Self-described "anti" and city charter signee Isidor Cohen explained that debates often culminated, "in fist fights with an occasional display of knives. ${ }^{\text {} 54}$ This corporate/anti-corporate conflict played out, as we will see in Chapter 2, between conservationist and commodity-oriented naturalists, embodied in the men of Charles Torrey Simpson and David Fairchild. The new century's dawn, though, did not arrive before the United States, in sublimating a genuine, multiethnic Cuban liberation movement fomented in Florida and supported by its citizens, declared war against its imperial predecessor.

The Spanish-American War of 1898 mobilized the newborn city for the effort, and 7,000 troops crowded the hastily built barracks at the old Fort Dallas site as well as at Flagler's newest resort, the Royal Palm Hotel, outnumbering the roughly 1,500 local residents. The troops were later remembered more for the harassment of local women, terror and violence brought upon the segregated black neighborhoods, and the brutal murder of at least one young black man while on their tour of duty. Local settlers feared Spanish incursions into Biscayne Bay because Spanish sponge divers in Cuba and the Keys were experts of south Florida's difficult waters, but those fears never materialized. The Cocoa, the first Spanish ship captured by the U.S. Navy after the explosion of the Maine, came from Havana to port in Miami, and large crowds reportedly greeted the captured crew, buying all manner of war paraphernalia off the captives as they boarded an

${ }^{54}$ Isidor Cohen, Historical Sketches and Sidelights of Miami, Florida (Miami: privately printed by the author, 1925) 24-25. 
FEC train to prison camps in northern Florida. ${ }^{55}$ Over the course of the nineteenth century, the United States had acquired the tools of colonial rule and territorial expansion through experience as well as engagement with Spain's established precedent. The 1898 Treaty of Paris, the last territorial treaty between Spain and the U.S., poetically concluded and reiterated the shared colonial history of the two empires. Spain was "gone" from the Western hemisphere, but its legacy lived on in efforts to consolidate the image and explain the position of the U.S. as a global power.

\section{Conclusion: The Reclaimed Empire}

Upon hearing of the capitalist's death in 1913, one of Henry Flagler's many admirers wrote that he had fulfilled a vision and executed "a dream of reclaimed empire for the enjoyment of mankind $[\ldots .$.$] it raises to a high and$ honorable place the individual accomplishment and emphasizes individual capacity, taste, and virtue, and belies the universal mediocrity of a socialist philosophy and ever nerves the human heart to successful and worthy endeavor." $" 56$ If there is anything "exceptional" about U.S. imperialism, it is this driving notion underlying the quoted passage: every individual could reclaim their own empire. No longer the exclusive patrimony of kings and popes, the global

${ }^{55}$ Cohen, Historical Sketches and Sidelights, 35-36.

${ }^{56}$ Charles Eugene Clark, A Tribute to the Life and Memory of that Princely American, the Late Henry M. Flagler, Through whose Splendid Efforts in Reclamation, Railways, Hotel and City Building, Florida, the Land of the Palm and Pine, was largely made Possible, and Habitable, and a Nation's Playground (Covington, KY: privately printed by the author, 1914) 6-7, emphasis added. 
American Empire of the twentieth century, part and parcel of Miami's history, expanded as a consequence of individual, private pursuits of property and capital. The cross and sword of Spanish conquest begot the ledgers and trade terms of the American conquest, and the Jesuit and Franciscan missionaries in search of souls unleashed financial missionaries beholden to a secular gospel of commerce and democracy in search of profit. ${ }^{57}$

On the eve of Miami's "magic" twentieth-century development, the frontier foundations below the fledgling new city's surface had witnessed four centuries of imperial efforts to bring the supposed greatness of Western Civilization to the peninsula's untamed subtropical south. Only the particular hubris of the Gilded Age and its attendant material advances, it seemed, could finally fulfill the dream of forging a metropolis out of the frontier wilderness, achieving the final and highest order of colonial rule. At the end of the nineteenth century, the United States, healed enough from its internal war and positioned favorably in the shifting, globalizing financial landscape, looked to Latin America and the wider world with the same lustful gaze that Spain once held fixed in its direction. ${ }^{58}$ From the beginning, Miami's pioneer settlers envisioned the city's

${ }^{57}$ Emily S. Rosenberg, Financial Missionaries to the World: The Politics and Culture of Dollar Diplomacy, 1900-1930 (Durham, NC: Duke University Press, 2004).

${ }^{58}$ For the unifying forces of the nation-state experienced during the Gilded Age, see, for instance, Alan Trachtenberg's The Incorporation of America: Culture and Society in the Gilded Age (New York: Hill \& Wang, 1982). For the rise of American Empire during the Gilded Age with respect to Latin America, see Walter LeFeber, The New Empire: An Interpretation of American Expansion, 1860-1898 (Ithaca, NY: Cornell University Press, 1963), Greg Grandin, Empire's Workshop: Latin America, the United States, and the Rise of the New Imperialism 
future growth as dependent on its increased interaction with Latin America.

Spectacular as the prediction now seems, Julia Tuttle, in a recollected 1896

interview with Ethan V. Blackman, boldly outlined her vision for the potential

future of the city:

"It will not be many years hence when Miami will be the most important port on the Atlantic Coast in the South. The time will come when the harbor and its approach will be dredged to a depth that will allow the deep sea-going vessels to anchor. Not only will this bring in the coastwise steamers, whose captains now cast longing eyes toward Miami as they pass, but the South American vessels will finally ply between their home ports and Miami, and Miami will become the great center of the South American trade. Vessels from all ports of the world will call at Miami, making Miami the greatest commercial center in all the south land. This may seem far-fetched to you, but as surely as the sun rises and sets all of this will come true." 59

From the District of Columbia to California, Spain's colonial legacy and its significance for U.S. history cannot be overstated. Nineteenth-century writers like Washington Irving and historian William H. Prescott inaugurated

(New York: Metropolitan Books, 2006), and Louis A. Pérez, Jr., Cuba in the American Imagination: Metaphor and the Imperial Ethos (Chapel Hill, NC: University of North Carolina Press, 2008). For Latin America's increasing reliance on U.S. capital and the economic issues engendered, see Carlos Marichal, A Century of Debt Crises in Latin America: From Independence to the Great Depression, 1820-1930 (Princeton: Princeton University Press, 1989). The significance of overseas territorial acquisition for the growth of the U.S. State is analyzed from a variety of perspectives in Colonial Crucible: Empire in the Making of the American State, edited by Alfred W. McCoy and Francisco A. Scarano (Madison, WI: University of Wisconsin Press, 2009); see also, Karl Polyani, The Great Transformation: The Political and Economic Origins of Our Time (Boston: Beacon Press, 2001) for an analysis of the global financial restructuring of the late-nineteenth century, the growing market imperative, and the favorable positioning of the United States and northern Europe.

${ }^{59}$ Ethan V. Blackman, Miami and Dade County, Florida: Its Settlement, Progress and Achievement (Washington, DC: Victor Rainbolt, 1921) 59. 
Hispanophilic studies in the United States, and later generations of artists, architects, and scholars expanded and enriched the study and historical memory of the New World's Spanish past while simultaneously delegitimizing the perceived decadence and decay of contemporary Spain. ${ }^{60}$ U.S. territorial expansion to Florida and to western North America reanimated colonial experiences Spain first enacted as it naturalized and named for itself south Florida's spaces. Miami pioneers and city planners both strategically and unreflexively repeated their imperial spatial project as a meaningful framework for urban design and aesthetics in pursuit of a unique regional vernacular, discussed below in Chapter 3. The romance and rise of the American tropics, though, bore the fruit of Miami's initial urban growth in its transition from a colonial frontier to an imperial city, the subject of Chapter 2 .

2013 marked the $500^{\text {th }}$ anniversary of Juan Ponce de León's “discovery” of Florida. Quincentennial commemorations came in many forms, ranging from Florida Lottery scratch-off tickets with treasure chests and stylized images of the Spanish explorer to historical documentaries on local public television stations. In Miami, the anniversary prompted a gala event at the Freedom Tower, a 1925 replica of Seville's Giralda Tower, that featured two very appropriate guests of honor, the Prince and Princess of Asturias. The heirs to the Spanish throne wined and dined with members of Miami's elite, they helped kick off the thirtieth annual

${ }^{60}$ Richard L. Kagan, "Prescott's Paradigm: American Historical Scholarship and the Decline of Spain," American Historical Review, Vol. 101, No. 2 (Apr., 1996): 423-446; Ricardo D. Salvatore, "Imperial Revisionism: US Historians of Latin America and the Spanish Colonial Empire (ca. 1915-1945)," Journal of Transnational American Studies, Vol. 5, No. 1 (2013). 
Miami Book Fair International, they accepted gifts of keys to the city as well as reproduced Florida maps from the sixteenth century, and they spoke of Florida's storied relationship with its former metropole. "Without the Spanish presence, we could not understand today's Florida," said Prince Felipe, "and we cannot imagine today's United States without its Spanish legacy."

${ }^{61}$ Maria Perez, "Spanish Royalty in Miami to Celebrate 500-year Link to Florida," Miami Herald, Nov. 18, 2013. 


\section{CHAPTER II}

\section{Growing a Tropical City: Naturalists, Plant Immigrants, and the Seeds of Urbanization}

Plants operated as part of a conscious strategy from the 1830s through the 1920s to signal south Florida and Miami as a particular kind of environmenttropical, but not overbearingly so, free of burdensome social problems, and open for business. Doctors, scientists, business leaders, and government officials remade south Florida in this image as they developed the city for agriculture, tourism, and settlement. City boosters, plant explorers, farmers, and gardeners introduced a wide variety of new plants into the area, displacing the native vegetation and ushering in an era of sustained urban development. In the process of growing the city's tropicality, connections developed between south Florida, the Caribbean, and Latin America. Human activity intended to shape the city as part of the tropics, then, bore considerable and durable fruit.

Henry Perrine, a medical doctor and U.S. consul in Mexico in the 1820s1830s, inaugurated the work of tropical plant introduction in south Florida and prompted investment in agricultural research at the national level. With the formal incorporation of Miami in 1896, tropical plant research and production mirrored and reinforced the growth of the city. Plant explorers and naturalists like David Fairchild and Wilson Popenoe, working in the service of state and capital, scoured the globe for tropical seeds and cultivars intended to bolster and expand domestic agricultural production capacity in south Florida, California, Hawaii, and 
elsewhere. ${ }^{1}$ The plant "immigrants" that traveled back from globetrotting explorations found safe haven in Miami's nurseries and gardens. The United States Department of Agriculture's experimental gardens in Miami, first established in 1898, nurtured the steady stream of exotic plants that arrived via the USDA's Bureau of Foreign Seed and Plant Introduction, an institutional outcropping of the nation's imperial acquisitions at the turn of the century. Local nurserymen and women in Miami discovered best practices for tropical agriculture, which then emanated to other research stations in the USDA system as successful experiments became replicable and predictable. U.S. multinational corporations and state agencies like the USDA revolutionized global food production, but the work done in Miami is largely overlooked as a harbinger of that revolutionary process. ${ }^{2}$

By the 1920s, a tropical culture coalesced amongst the white capitalist class that called Miami a winter home. Tropical flowers such as orchids and plants such as palm trees and bougainvillea decorated planned communities and beautified tea and dinner fetes, with Miami Beach Garden Club President Leticia Southerland's Tropical Flower Show the exclamation point of each winter season.

\footnotetext{
${ }^{1}$ Amanda Harris, Fruits of Eden: David Fairchild and America's Plant Hunters (Gainesville, FL: University Press of Florida, 2015); Frederic Rosengarten, Jr., Wilson Popenoe: Agricultural Explorer, Educator, and Friend of Latin America (Lawai, HI: National Tropical Botanical Garden, 1991).

${ }^{2}$ Stuart McCook, for example, offers a useful overview of the institutional growth of the USDA nationally and globally, yet he neglects to mention the Miami experimental gardens that predated the list of research stations he provides in McCook, "'The World Was My Garden': Tropical Botany and Cosmopolitanism in American Science, 1898-1935," in Colonial Crucible: Empire in the Making of the Modern American State (Madison, WI: University of Wisconsin Press, 2009), edited by Alfred McCoy and Francisco Scarano, 499-507.
} 
The rapid transformation from pineland and alluvial grassland to a tropical city was not without its critics, perhaps none more articulate and pointed than naturalist Charles Torrey Simpson. Simpson, though, espoused both the discourse of conservation and the detailed instructions to remake south Florida into a tropical paradise, a tension highlighted in this chapter's final section. As natural as the tropical landscape now appears to Miami's inhabitants and visitors, the initiation and growth of tropical Miami is historically locatable and was contingent upon human intention. Miami's tropical landscape bloomed as a reflection of the city's and the nation's increased interest and interaction with the world.

\section{Geographical Precursors to a Tropical Transformation}

The Florida Plateau juts out from the North American continental plate and into the Caribbean basin on a slowly-descendent grade of elevation from the heights of the Appalachian Mountains, with the sand found along the 1,350-mile coastline originating from those mountains' erosion and glacial crawl to lower ground. As the world oceans fluctuated on the scale of geologic time, a peninsula atop the plateau emerged, disappeared, and reemerged from below a shallow lakebed dating to the relatively recent past, some 120,000 years ago. The watery cover between the land and sun over time deposited oolitic limestone along the southeastern terminus of the peninsula, which resulted in an elevated limestone ridge between the shore on the east and the lower-elevation, seasonally flooded grasslands to the west. No wider than ten miles from west to east, the limestone 
ridge extends over 80 miles from north to south, with stones occasionally protruding above the otherwise sandy soil. The ridge nurtured one of three distinct ecological zones; a rich pineland forest bordered on the shore by thickly interwoven, hardwood mangrove hammocks, and on the west by the sawgrass wetlands replenished by Lake Okeechobee on its southward drainage path to the sea. Freshwater rivers continue the drainage path from the lake to the ocean in a southeasterly orientation. The most prominent of these drainage rivers, the Miami River, spills out into the large, semi-enclosed Biscayne Bay, the largest protected bay on the Florida's east coast, where barrier islands, or keys, begin to break away from the mainland, forming a south-by-westerly crescent of protective islands where the open ocean, a warmer sea, and the peninsula converge.

Prevailing currents push warm winds in a clockwise motion from the southeastern entrance of the Caribbean around and back to the northeast where the peninsula terminates and out to the open ocean. These warmer, more humid winds abut the cooler, drier air swept down from the distant Rocky Mountain range. The strength of the cold mountain air significantly diminishes as it reaches the peninsula's southern extreme, which contributes, along with the latitudinal proximity to the equator, to a semi-tropical climate characterized by drier winters from approximately November to April, and rainier summers from May to October, with little intermediate seasonal change compared to the northern and southern temperate zones but also with less dramatic seasonal precipitation change compared to the tropics. The climatic and geographical conditions 
permitted the successful introduction of non-native flora and fauna and the promotion of south Florida as an American tropical region.

\section{A Thin Slice of The New World's Natural History}

Evidenced by Gonzalo Fernández de Oviedo’s monumental Historia general y natural de las Indias, islas y Tierra-Firme del Mar Oceano (1535), the discovery of the New World required new vocabularies and new knowledges to better approximate the environments, flora, and fauna encountered along the path of imperial conquest, just as knowledge of the people inhabiting those encountered places mattered for maintenance of colonial power that we saw in chapter one. Efforts to write the natural history of the New World resulted in taxonomical revolutions for the science of the Old World. Monoliths of Western natural science like von Humboldt and Darwin constructed their grand theories of biological distribution and evolution in situ during their firsthand encounters with the New World. ${ }^{3}$ The constant stream of exotic plants that flowed into the imperial botanical gardens and hothouses of Europe proffered objects of study for generations of scientific observers including Linnaeus. The Columbian Exchange constituted a global redistribution of plants, animals, and bacteria, as significant for the gastronomy and agricultural practices of Europe, Africa, and Asia as for

\footnotetext{
${ }^{3}$ Jorge Cañizares-Esguerra, Nature, Empire, and Nation: Explorations of the History of Science in the Iberian World (Palo Alto, CA: Stanford University Press, 2006); Visions of Empire: Voyages, Botany, and Representations of Nature (Cambridge, UK: Cambridge University Press, 1996), edited by David Philip Miller and Peter Hanns Reill; Londa Schiebinger, Plants and Empire: Colonial Bioprospecting in the Atlantic World (Cambridge, MA: Harvard University Press, 2004).
} 
the Americas. Flowers, fruits, vegetables, and spices, as much as silver and gold, fueled the increased interaction and growing mutual dependence of once distant places and first traced out the circuits and contours of globalization. ${ }^{4}$ U.S. and European imperial activities in the nineteenth and twentieth centuries accelerated those processes, expanded the geographical scope of global biological transfers, and increasingly relied on scientific knowledge and institutions in what environmental historian Stuart McCook appropriately characterizes as a NeoColumbian Exchange. ${ }^{5}$

Constructs of race and racial difference fundamentally relied on an understanding and valuation of climates and environments. European observers ascribed climate-based racial inferiority to Africans, Asians, and Amerindians living in the torrid zones. ${ }^{6}$ Despite the persistence of environmental determinism well into the twentieth century, countervailing narratives of the tropics began to emerge in the nineteenth century as U.S. and European tourism industries began to sell the tropics and warmer climates as places of racial betterment and healthful

\footnotetext{
${ }^{4}$ Alfred J. Crosby, The Columbian Exchange: Biological and Cultural Consequences of 1492 (Wesport, CT: Greenwood, 1972); Crosby, Ecological Imperialism: The Biological Expansion of Europe 900-1900 (New York: Cambridge University Press, 2004).

${ }^{5}$ Stuart McCook, "The Neo-Columbian Exchange: The Second Conquest of the Greater Caribbean, 1720-1930," Latin American Research Review, Vol. 46, Special Issue: Contemporary Debates on Ecology, Society, and Culture in Latin America (2011): 11-31.

${ }^{6}$ Gary Y. Okihiro, Pineapple Culture: A History of the Tropical and Temperate Zones (Berkeley, CA: University of California Press, 2009), 5-22.
} 
recovery for overcivilized and frostbitten northern whites. ${ }^{7}$ South Florida embodied a certain vanguard of such reinterpretations because of its sparse population and the need to lure potential colonial settlers. In particular, the work of one man, a doctor from New Jersey and U.S. Consul in Campeche, Mexico, conferred positive attributes of the tropics onto south Florida in order to expand commodity production for the United States.

\section{Dr. Henry Perrine's Tropical Florida Legacy}

Henry Perrine, a medical doctor from New Jersey trained at New York University, began his career as a public servant in 1827 as U.S. Consul at Campeche, Tabasco, and surrounding Gulf ports of Mexico, a post he held for a decade. His reputation as a serious man of science grew significantly during his stay in Mexico. Instead of using his medical expertise as a means of wealth accumulation, Perrine medically treated poor and rich alike in Mexico in order to gain local knowledge about tropical plants in exchange for his services.

Government officials in Mexico and elsewhere were highly suspicious of foreigners who inquired to any degree about local agricultural practices and plant species, as they rightly saw in those inquiries the sources of competition for their natural monopolies, but Perrine's medical practice mostly shielded him from such

${ }^{7}$ Catherine Cocks, "The Pleasures of Degeneration: Climate, Race, and the Origins of the Global Tourist South in the Americas," Discourse, Vol. 29, No. 2 \& 3 (Spr. and Fall 2007): 215-235. 
suspicions. ${ }^{8}$ The U.S. Treasury Department's request, initiated by imperiallyminded President John Quincy Adams, to all of its foreign consuls to find any useful plants that could be introduced to the U.S. mostly fell on deaf ears, with the exception of Perrine. A Treasury Circular from 1827 summed up Perrine's significance, as it stated that, "Dr. H. Perrine appears to be the only American Consul who has unreservedly devoted with his head, heart, and hands to the subject of introducing tropical plants in the United States and his voluminous manuscripts alone exhibit a great amount of labor and research which promises to be highly beneficial to our common country." ${ }^{.9}$ His letters and correspondence with agricultural societies, scientific communities, as well as with state and federal government officials circulated widely in the U.S. during his time in Mexico. ${ }^{10}$

In the process of his correspondence, Perrine garnered federal government support for agricultural research for the first time in the nation's history. Never before had federal appropriations been made for agricultural research or production, as no department of agriculture yet existed. Perrine's successful petition for reimbursement in exchange for his years of service in the form of land

${ }^{8}$ See letter by Manuel Ortiz and Estevan Valay de Gonzales from the Ayuntamiento de Campeche, Dr. Henry Perrine, Tropical Plants (Washington, DC: Congressional Printing Office, 1838), 46-47; and "Obstacles in the Collection of Information and Plants in and from Mexico," Ibid., 55-59.

${ }^{9}$ Treasury Department Circular, September 7, 1827. Quoted in T. Ralph Robinson, "Henry Perrine: Pioneer Horticulturalist of Florida," Tequesta, Vol. 1, No. 3 (1941): 17.

${ }^{10}$ Congress ordered 5,000 copies of Dr. Henry Perrine, Tropical Plants to be distributed to various states. 
in what he called "tropical Florida" represented the first federal investment in agricultural research, and the first time anyone characterized south Florida as tropical. Perrine contributed substantially to the history of south Florida and to the history of agricultural research in the United States.

One of the many letters collected and printed by the U.S. Congress to highlight Perrine's work succinctly captured the vision he held for south Florida and the national implications he foresaw in his own work. In the context of increasing division between northern and southern states along the axis of enslaved labor, the northerner in Perrine stressed the less labor-intensive crops from Mexico as a solution to the South's labor problems: "The introduction of valuable vegetables to the industry of the South, is a sure and speedy remedy for its existing distress. With the fibres [sic] of one exotic vegetable [cotton], our Southern States have hitherto furnished a material of clothing of a great proportion of the human race; and with the fibres of other exotic vegetables, they may hereafter supply the materials for thread, twine, and cordage, cambric and canvass, and diversified manufactures, to a great majority of the civilized world." 11 Perrine privileged the introduction of fibrous agaves known as Henequen, Pita, and a variety he called Sisal after the Mexican port town, but which others understood as an aloe. The latter's full contemporary taxonomical name is agave sisalana Perrine as a lasting reminder of his contribution to tropical plant science. According to Perrine, the entire world's tropical plants could realize

\footnotetext{
${ }^{11}$ Henry Perrine, "To the intelligent friends of the Union," October 4, 1832, New York Farmer, reprinted in Dr. Henry Perrine, Tropical Plants, 40-41.
} 
their full potential in the United States: "There are thousands [of tropical plants] whose varied productions are still more profitable, in proportion to the capital employed, which once within the range of American enterprise, industry, intelligence, and ingenuity will become converted into mines of vegetable wealth, of which their barbarous native countries have never even dreamed." ${ }^{, 2}$ White free labor, with its intellectual and enterprising advantages so rendered, would achieve the dual goal of increased agricultural diversity for U.S. producers and decreased reliance on enslaved labor.

This grand agricultural revolution hinged on the establishment of south Florida as the intermediary between tropical plants in their native state and their ultimate destination throughout the U.S. South. "The foregoing considerations demand the immediate establishment of a nursery of tropical plants at or near Cape Florida," Perrine wrote. ${ }^{13}$ South Florida afforded distinct advantages for tropical plant research because its climate related closer to the Caribbean than the southern states:

The climates of the northern and southern halves of the peninsula of Florida are different in kind or distinct in character [.... St. Augustine resembles Charleston and New Orleans, in the humidity of its winter and the transitions of its temperature. Cape Florida resembles Matanzas [Cuba] and Campeachy [sic], in the dryness of its winter and the uniformity of its temperature. The southern half of Florida has also the perpetual trade winds, the daily sea and nightly land breeze, and the rainy summer of the islands of Cuba, Hayti [sic], Jamaica, and Puerto Rico, and of the whole peninsula of Yucatan. Hence

${ }^{12}$ Ibid., 41.

${ }^{13}$ Ibid., 42. 
it combines all the phenomena of a tropical climate, viz: a constant aerial current to the west; an alternate land and sea breeze; a delicious dry, and a refreshing wet season; and a great uniformity of temperature throughout the year. But tropical Florida, as it may now be called, must be blessed with a still greater equality of temperature than either the islands of the West Indies or the peninsula of Yucatan [....] Its happy equilibrium must be sustained by a friend peculiarly its own - the great Gulf stream, which cherishes the shores it embraces with the heat which its brings from the equatorial seas [....] The whole extent, then, of southern Florida must present unparalleled advantages for vegetable cultivation. ${ }^{14}$

Although important naturalists like William Bartram predated Perrine's writings regarding Florida, Perrine popularized the use of "tropical Florida" to describe south Florida for the U.S. reading public. ${ }^{15}$

From Mexico, Perrine sent whatever he could to Charles Howe, the port inspector and postmaster of Indian Key, south of Cape Florida, so that Howe could begin the work of an introduction garden in Perrine's absence. Perrine sent bananas and cocoa-palms to Howe to prove his argument about south Florida's tropical climate. Under the right conditions, bananas and coconuts self-propagate at exceptional rates with little additional care needed. In a letter to the secretary of the Treasury Department, dated September 12, 1833, Perrine enumerated the great

${ }^{14}$ Ibid., 40-44, emphasis added.

${ }^{15}$ Bartram only traveled as far south as Cape Canaveral. William Bartram, Travels through North \& South Carolina, Georgia, East \& West Florida, The Cherokee Country, The Extensive Territories of the Muscogulges, or Creek Confederacy, and the Country of the Chactaw: Containing An Account of the Soil and Natural Productions of those Regions, Together with Observations on the Manners of the Indians, Embellished with Copper Plates (Philadelphia, PA: James and Johnson, 1791). 
variety of tropical plants he sent to south Florida for experiments. ${ }^{16}$ Howe faced the same problems in propagating plants that many other colonial settlers of south Florida experienced that we saw in chapter one, namely the fiercely resistant and tactically superior Seminoles and so-called "Spanish Indians," most likely descendants of the Tequesta. Reports from Howe to Perrine throughout the 1830s lamented the need to periodically abandon the experimental plantings due to sustained Seminole attacks. ${ }^{17}$

${ }^{16}$ Henry Perrine, "Extract of a postscript to a letter to the Secretary of the Treasury," September 12, 1833, Dr. Henry Perrine, Tropical Plants, 47. Nutritive roots: Jatropha manihot (cassava), two varieties; Marantha indica and alloui, two species; Arum sagitifolium (arrowleaf elephant's ear); Dioscorea alata (purple yam), sativa and bulbifera (air potato), three species; Alstroemeria edulis (tussac) and latifola (Peruvian lilly), two species; phaseolus tuberosus (root or sago), two or three varieties. - Edible fruits: Persea gratisima (avocado); Mangifera domestica (mango); Anacardium occidentale (cashew); Annona squamosa (sugar apple) and Muricata (custard apple); Chrysophyllum cainito (star apple) and oliviforme (satinleaf); Lucuma bomplandia; Mammea Americana (mammee apple); Tamarindus occidentalis (tamarind); Melicocca bijuga (Spanish or Mexican lime); Moringa pterigosperma (horseradish tree); Malpighia mourelia (Barbados cherry). - Coloring materials: Bixa orellana (achiote); Curcuma Americana (leren); Cactus cochenillifera (prickly-pear cactus). - Oils: Moringa pterigosperma (ben oil); Alfonsia oleifera (American oil palm); Jatropha curcas (Barbados nut or curcas). - Cortical fibres: Hibiscus tiliaceus (sea hibiscus); corchorus siliquosus (slippery burr). - Capsular fibres: Gossypium, two species kidney and nankin cotton. - Odors: Vanilla aromatic; Hibiscus abelmoschus (musk mallow). -Foliaceous fibres: Agave Sisalana; two varieties of Henequen; Furcroea foetida, or B. pita. - Drink: Agave Americana, or maguey de pulque; Coffea Arabica; Theobroma cacao. - Naval timber trees: Piscidia erythrina (Jamaican dogwood or Florida fishpoison tree); Cedrela odorata (Spanish cedar). Smoking: Tobacco, various varieties of its native country.

17 "Extracts of letters from Charles Howe, Inspector and Postmaster at Indian Key, Tropical Florida, to Doctor Henry Perrine, at Washington City," September 2, 1837 in Dr. Henry Perrine, Tropical Plants, 59. 
After years of lobbying on his own behalf, the U.S. Congress granted Perrine south Florida land in 1838 for his services to the nation. ${ }^{18}$ In addition, the Florida state legislature approved an act of incorporation for the Tropical Plant Company, cosigned by Perrine and Howe. News of the approved land and business grants prompted Perrine to move on to his grant in 1838 along with his wife, son, and daughter. Because of continued hostilities with south Florida Amerindians, the Perrines settled on Indian Key off the mainland. For eighteen months, Perrine busied himself with propagations and new plant introductions, but he would not live long enough to fully realize the fruits of his labor. In the early hours of August 7, 1840, a band of Amerindians arrived on the key and set fire to the Perrine house and all other buildings on the island. Perrine's wife, daughter, and son managed to escape, but they discovered Dr. Perrine's charred remains the following day and buried them on Matecumbe Key at the base of one of the sisal agaves Perrine sent for introduction. ${ }^{19}$ His son and several other families from western New York reoccupied the Perrine grant in the 1870s. Descendants of Perrine, Charles Howe, and interested parties from the Florida East Coast (FEC) Railroad later argued over the full extent of the grant and the rightful heirs, with the FEC and Flagler eventually attaining rights to build the

\footnotetext{
18 "An act to encourage the introduction and promote the cultivation of tropical plants in the United States," U.S. Congress, 25th Congress, Session 2, Chapter 188, Statute 2, Jul. 7, 1838.

${ }^{19}$ T. Ralph Robinson, "Henry Perrine: Pioneer Horticulturalist of Florida," Tequesta, Vol. 1, No. 3 (1941): 18-19. See also Henry E. Perrine, The True Story of Some Eventful Years in Grandpa's Life (Buffalo, NY: Privately printed by author, 1885); Kaye Edwards Carter, Henry Perrine: Plant Pioneer of the Florida Frontier (Lake Buena Vista, FL: Tailored Tours, 1998).
} 
railroad through the property from Miami to Homestead and on to the Keys. Perrineville, fifteen miles southwest of Miami, became a small town later shortened in name to Perrine, later further divided into East and West Perrine along strictly racial lines, with the area east of the FEC tracks exclusively white and the area west exclusively black. ${ }^{20}$

The celebrated local variety of citrus known as the Key lime descended from Perrine's introduction of the Mexican or Spanish lime. Sisal agave, date and coconut palms, mangos, and avocado, among others, grew wild in the upper keys and on the south Florida mainland for years, silent memorials to Perrine. Perrine's death, continued war against Seminoles and other south Florida Amerindians, lack of sustainable transportation, and the prospect of other frontiers further west combined to delay the work of plant introduction and as well as to forestall dense colonial settlement in south Florida until the 1890s. Perrine's work to fully realize tropical Florida commenced once more only after the establishment of the Land Grant college system and the formal establishment of the Department of Agriculture both in 1862, and later with the creation of the USDA Foreign Seed and Plant Introduction section in 1898, concurrent with the imperial acquisition of globe-spanning territories in the torrid zone.

${ }^{20}$ Susan Oltman Fink, "Politics and Prayer in West Perrine, Florida: Civic Social Capital and the Black Church," (PhD diss., Florida International University, 2005). 


\section{The Romance and Rise of Miami as a Tropical City}

In a Department of Agriculture report from 1892, the special agent in charge of fiber investigations, Charles Richard Dodge, described the extent of sisal agave production in south Florida. From the New River to the Keys, sisal agave plantations dotted the lower east coast of the peninsula, and Dodge counted over 100,000 wild and cultivated sisal plants on his reconnaissance (Fg. 2.1-2.2). "During the past forty or fifty years," Dodge wrote, "sisal enthusiasts have endeavored to carry out Dr. Perrine's work of establishing this industry in Florida." ${ }^{21}$ With its formal incorporation as a city in 1896, Miami’s initial growth depended on its advertised potential for tropical plant production, and the USDA played a pivotal role in the introduction and maintenance of new plant material for local experimental and commercial plantings. ${ }^{22}$

${ }^{21}$ Charles Richard Dodge, "Report of the Special Agent in Charge of Fiber Investigations," Report of the Secretary of Agriculture, 32nd Congress, Second Session, House of Representatives, Executive Document 1, Part 6 (Washington, DC: Congressional Printing Office, 1893), 361.

${ }^{22}$ For more on the early promotion of south Florida agricultural settlement, see, "Transcriptions of The Homeseeker: A Monthly Publication of the Model Land Company," introduced by Patrick Scott, Broward Legacy, Vol. 29, No. 1 (2009): 4-21; William E. Brown, Jr. and Karen Hudson, "Henry Flagler and the Model Land Company," Tequesta, Vol. 56 (1996) 44-78; and for more on the USDA and its research in south Florida, see R.J. Griesbach, 150 Years of Research at the United States Department of Agriculture: Plant Introduction and Breeding (Beltsville, MD: USDA Agricultural Research Service, 2013). 


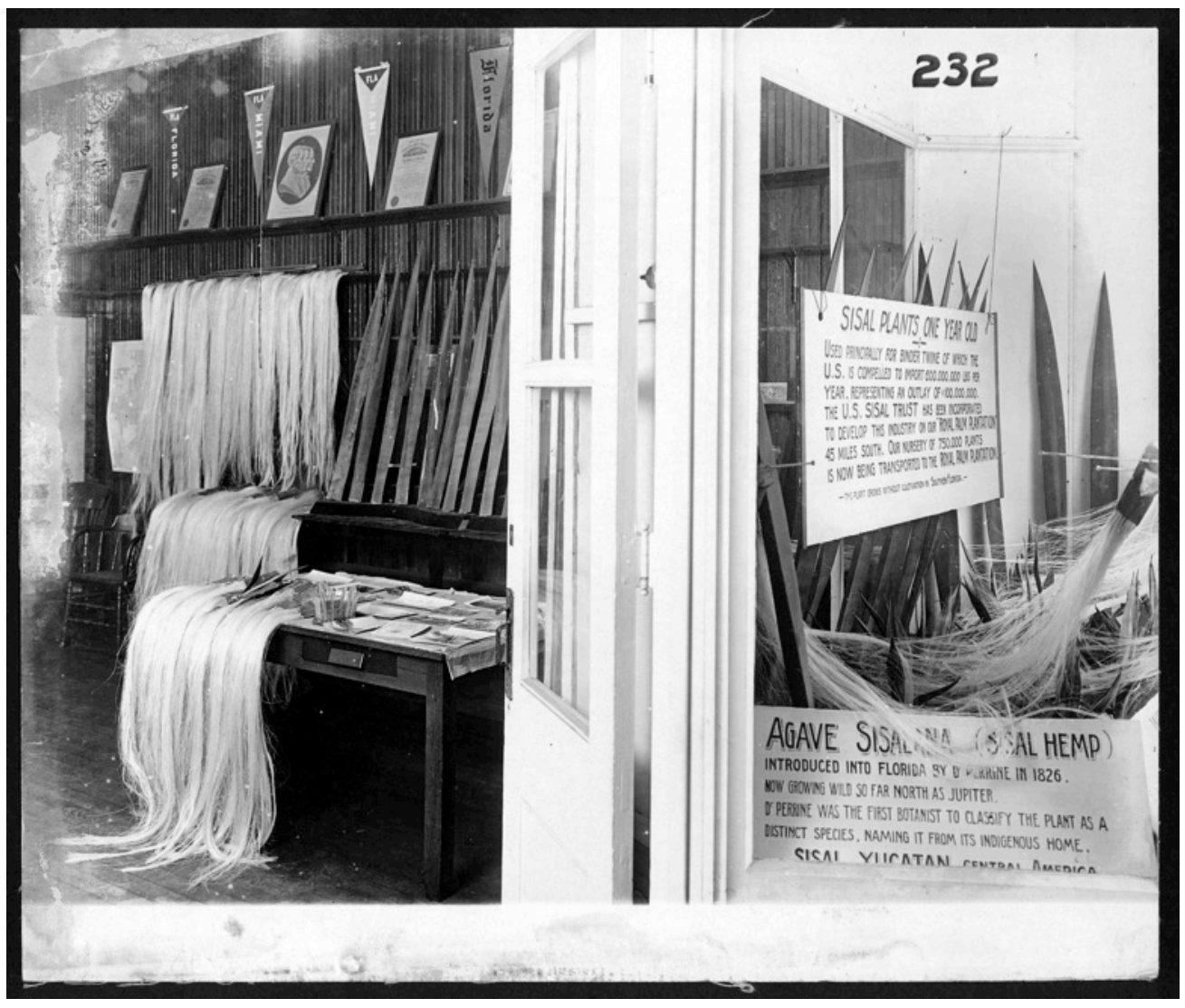

Figure 1.1 Unidentified storefront in Miami, dating from the 1900-1910s. Used with permission of HistoryMiami. The sign explains Henry Perrine's introduction, the fact that sisal grew wild as far north as Jupiter, and the image shows the finished cordage fibers from the sisal agave. 


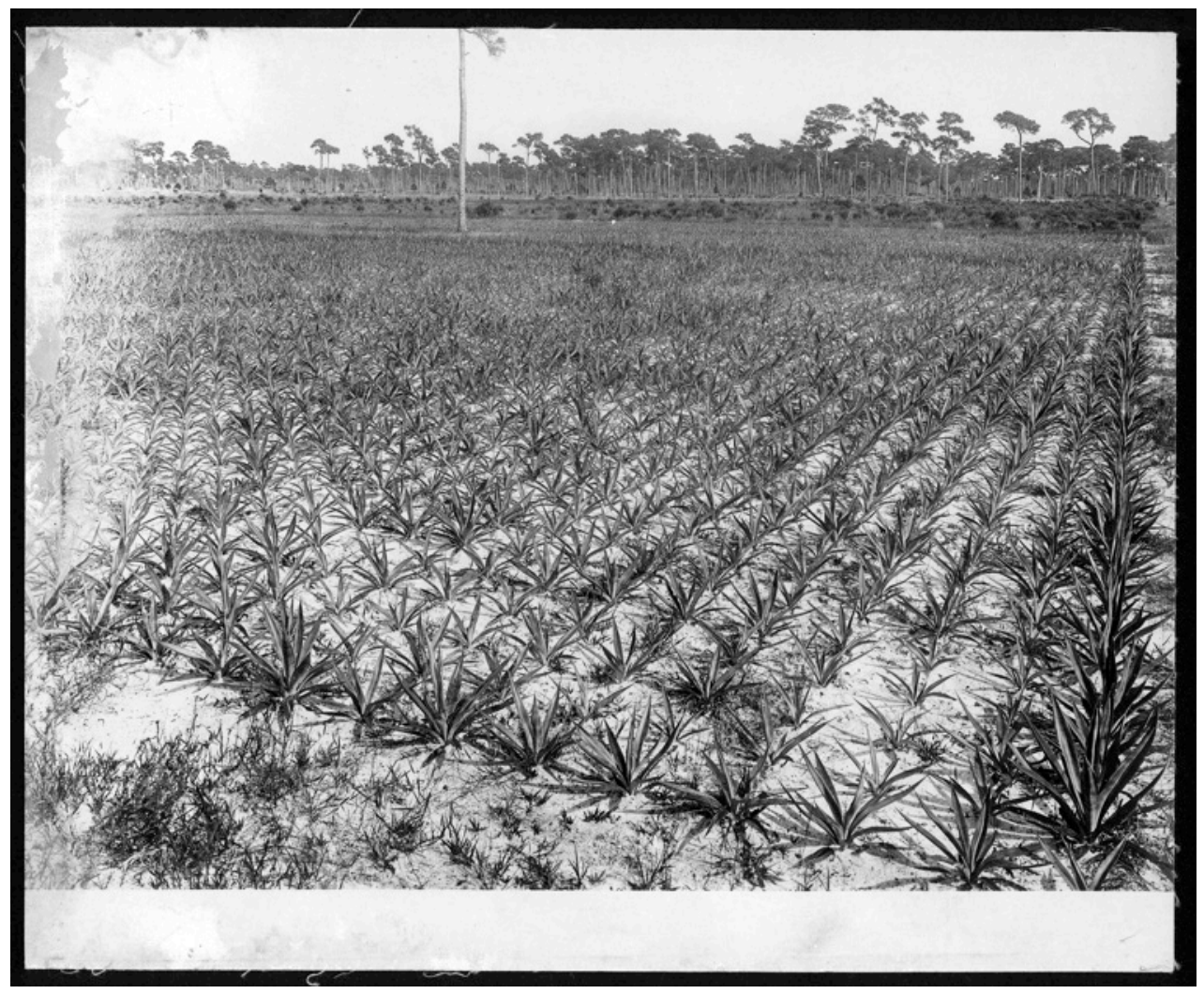

Figure 2.2 Evidence of extensive sisal production south of Miami, dating from 1910s. Used with permission of HistoryMiami.

The USDA's Section of Foreign Seed and Plant Introduction received its first allotment of $\$ 2000$ in 1898 , and a young plant explorer then traveling in Australia with his wealthy benefactor received word that he was to head the new unit. $^{23}$ David Fairchild, future son-in-law of Alexander Graham Bell and brotherin-law to National Geographic editor Gilbert Grosvenor, possessed a peculiar mix of having many friends in high places and a pioneer spirit undoubtedly rooted in his Kansas birthplace. Fairchild received continued support for his global plant explorations from capitalists Barbour Lathrop of Chicago and later Allison V.

${ }^{23}$ Knowles A. Ryerson, "The History of Plant Exploration and Introduction in the United States Department of Agriculture," Proceedings of the International Symposium on Plant Introduction, November 30-December 2, 1966 (Tegucigalpa, Honduras: Escuela Agricola Panamericana, 1967), 6-7. Ryseron replaced Fairchild as the head of plant introduction at the beginning of 1928. 
Armour of San Francisco. With the continental frontier eulogized by Frederick Jackson Turner in 1893 and nominally closed, Fairchild and his assembled band of experimental botanists and plant explorers sought new frontiers and new modes of exploration (new for the United States, anyways) to better understand, so as to better control and predict, the tropical world and acquire what a recent biographical title for Fairchild calls the "fruits of Eden." 24 Fairchild chose a site for the USDA's first tropical plant introduction garden on Brickell Avenue in 1898, encouraged by a small land donation from Mary Brickell and an initial investment from Henry Flagler of \$1000. Mostly absent from Miami until his retirement there in 1928, Fairchild entrusted the day-to-day operations of the test garden to Edward Simmonds, a Londoner and former employee of Kew Gardens. ${ }^{25}$ Waxing nostalgic about that early test site, Fairchild wrote, "Of the romance which gathered about that little clearing I could speak in general and passionate terms for it was one of the most interesting places in the world to me then and remains a memory of wonderful days spent with new plants which grew into trees that have been destroyed to make room for an apartment house."26 The romance of tropical plant research and production in south Florida flourished in

${ }^{24}$ Amanda Harris, Fruits of Eden: David Fairchild and America's Plant Hunters (Gainesville, FL: University Press of Florida, 2015). I am not primarily concerned with Fairchild as an individual as much as how he connects with Miami and its tropical experimental gardens.

${ }^{25}$ David Fairchild, "Some Plant Reminiscences of Southern Florida," Tequesta, Vol. 2 (1941): 8-15.

${ }^{26}$ Ibid., 9. 
increased tension with the growth of urban and suburban Miami, further explored below in chapter three.

Fairchild tapped as one of his explorers the son of a successful California agricultural speculator responsible for introducing Moroccan Medjool dates into that state. Frederic Wilson Popenoe, who dropped his first name following in the fashion of Thomas Woodrow Wilson, spent the better part of twenty years from the early 1900 s to the late 1910 s traveling throughout the Americas and the Caribbean for the USDA primarily in search of superior avocado cultivars. He then distributed the choicest specimens to south Florida, California, Hawaii, Cuba, Puerto Rico, Honduras, Guatemala, the Philippines, and elsewhere. His publications, including Manual of Tropical and Subtropical Fruits (1920), provided more information on the proper techniques and procedures to handle and grow avocados and other fruits like mango than any other publication written for the U.S. scientific community. ${ }^{27}$ Years later, Popenoe remarked on south Florida in a way that harkened back to Henry Perrine, saying, "There is something in the air in Florida which literally smells of the tropics, something which my tropical soul has always missed in California." 28

In Miami and Dade County, a few local commercial growers discovered through trial and error best practices to grow Popenoe's introduced specimens of

${ }^{27}$ Wilson Popenoe, Manual of Tropical and Subtropical Fruits, Excluding the Banana, Coconut, Pineapple, Citrus Fruits, Olive, and Fig (New York: Macmillan, 1920).

${ }^{28}$ Quoted in Frederic Rosengarten, Jr., Wilson Popenoe: Agricultural Explorer, Educator, and Friend of Latin America (Lawai, HI: National Tropical Botanical Garden, 1991), 35-36. 
avocado and mango. Of those, William Krome in Homestead and George Cellon in Miami succeeded where many other locals failed in propagating the cultivars sent from Popenoe and others, and Popenoe quoted Krome and Cellon extensively in his Manual. ${ }^{29}$ Fairchild later attributed to Cellon the first commercially grown avocado tree to bear fruit in the United States, a full decade before fruit bore on California's introduced trees, and Popenoe explained that Cellon's methods directly informed proper cultivation techniques for Florida and California growers. ${ }^{30}$ Cellon's seed and tree catalogue, begun in 1907, featured striking images of his choicest varieties, the first such commercial images of avocado and mango published in the U.S. (Fg. 2.3-2.5). ${ }^{31}$

Wilson Popenoe recorded data from Cellon and Krome on the market rates and destinations of Trapp and Pollock avocado varieties shipped from south Florida in the 1910s that illustrated the region's early production capacity relative to California. Philadelphia, Boston, New York, and Washington represented the major consumer markets, with additional shipments made to Chicago and Seattle, among other cities. At the time of Popenoe's writing in 1920, California's avocado production had not advanced to permit commercial shipments to the east

${ }^{29}$ Popenoe, Manual of Tropical and Subtropical Fruits, 25, 30, 34-35, 48-49, 54.

${ }^{30}$ David Fairchild, "Personal Recollections of George B. Cellon, Horticultural Pioneer of South Florida," Proceedings of the Florida State Horticultural Society, Vol. 54 (1945): 205-209; Carl W. Campbell and Robert J. Knight, Jr., "The Kromes, Pioneers in the Tropical Fruit Industry of Florida," Proceedings of the Florida State Horticultural Society, Vol. 111 (1998): 294-295; Popenoe, Manual of Tropical and Subtropical Fruits, 40-41.

${ }^{31}$ George B. Cellon, Descriptive List of Commercial Varieties of Tropical Fruit Trees (Miami: Privately printed by author, 1907). 
coast. Depending on the size of the south Florida Trapp and Pollock avocados, twenty-three to fifty-four fruits per crate brought anywhere from $\$ 5.25$ to over $\$ 36$ depending on the season, with the peak prices earned in the winter months of January and February. ${ }^{32}$ California's production capacity increased dramatically over the next two decades, while south Florida's market share declined significantly from its heights in the 1910s. From 1940-1945, Florida produced only thirteen percent of the avocados sold in the United States, while California produced seventy-three percent, with the remaining fourteen percent sourced from Cuba. $^{33}$

${ }^{32}$ Popenoe, $56-58$.

${ }^{33}$ H.S. Wolfe, L.R. Toy, and A.L. Stohl, "Avocado Production in Florida," USDA Agricultural Extension Service, Bulletin 141 (Dec., 1949), in "Fruit" Folder, Pamphlet Section "F", Charlton W. Tebeau Research Library, HistoryMiami. 


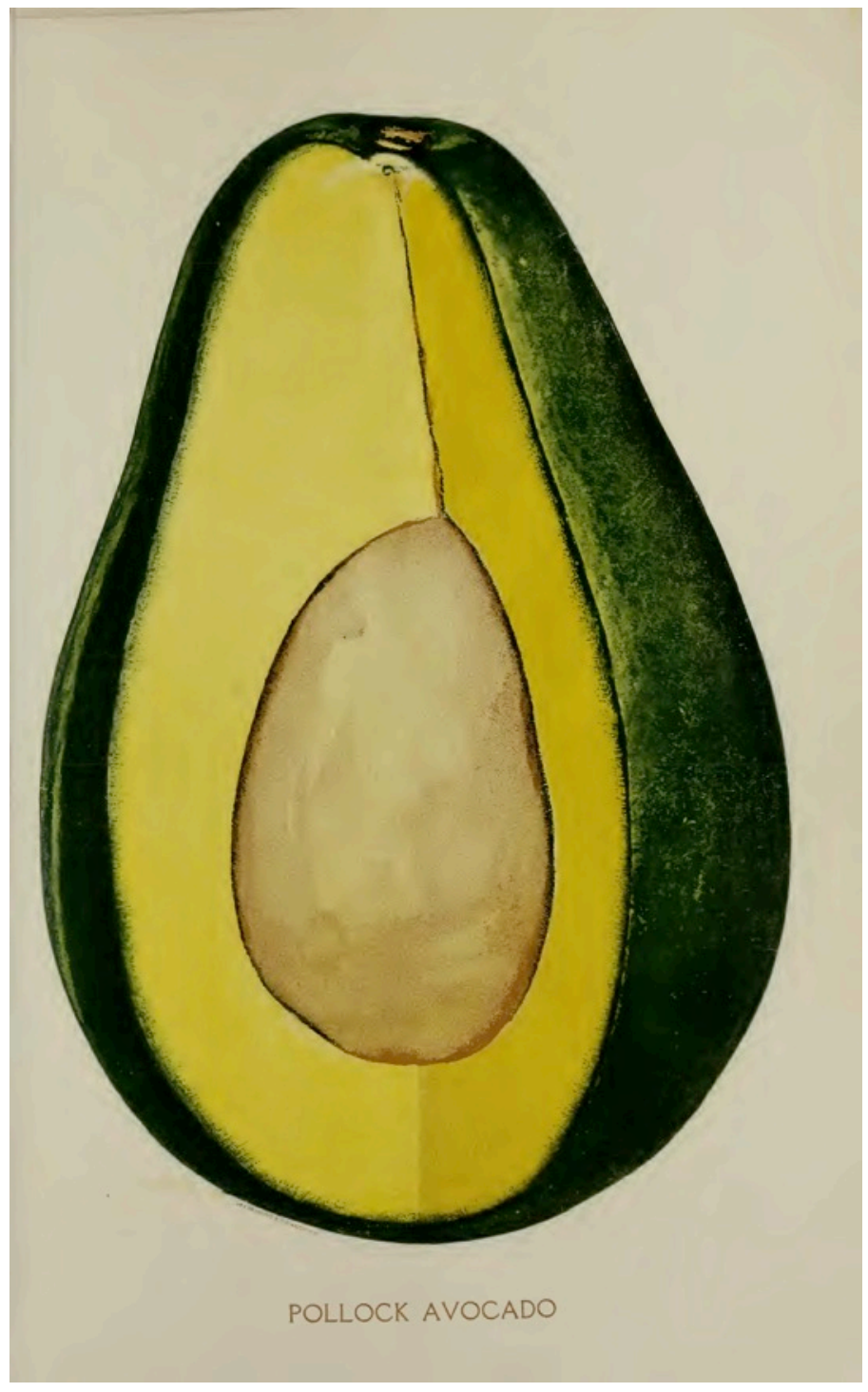

Figure 2.3 Example of Pollock Avocado from George

B..Cellon's 1907 catalogue. Public domain. 


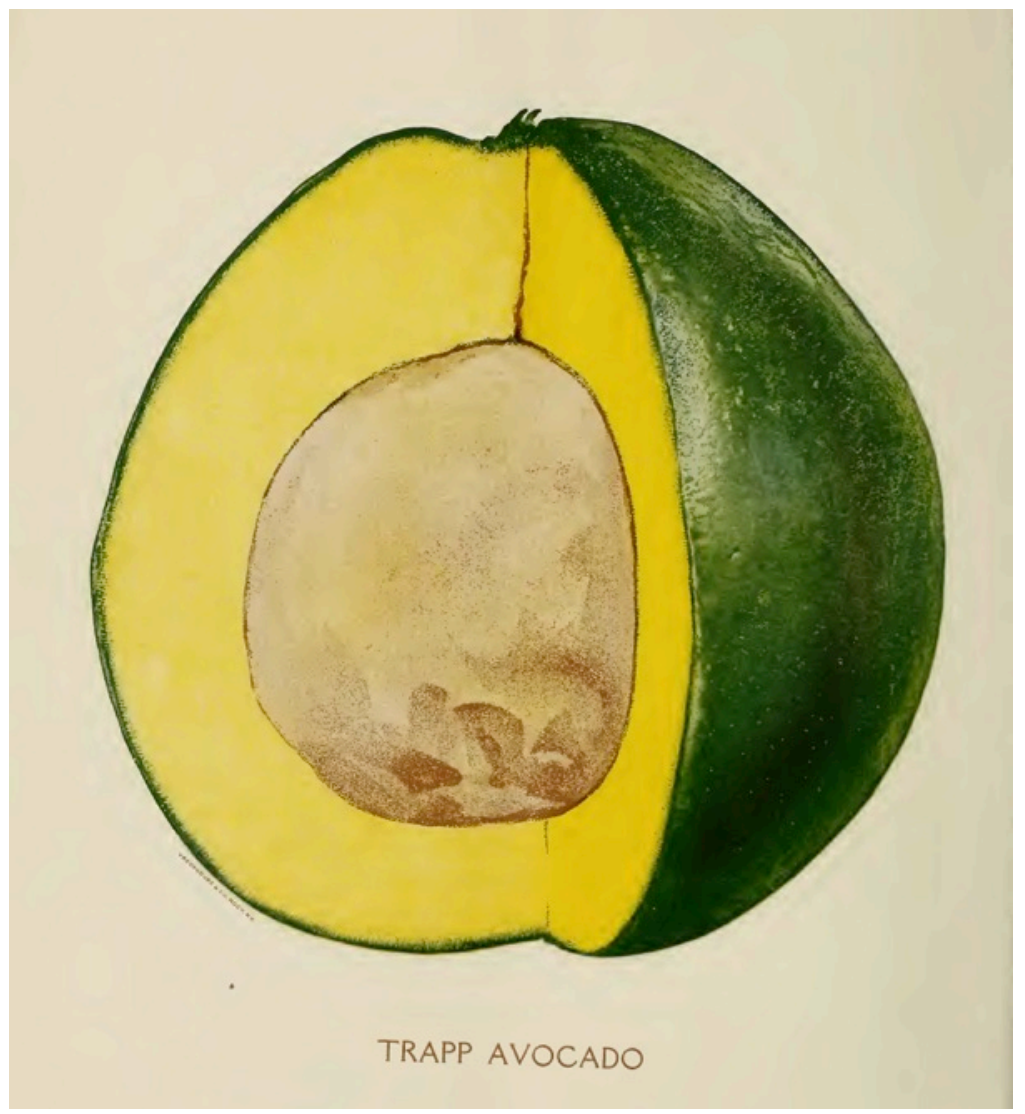

Figure 2.4 Example of Trapp Avocado from George B. Cellon's 1907 catalogue. Public Domain.

By 1910, several local families grew tropical fruit trees in and around Miami. Cellon's nursery and the USDA test garden distributed proven seedlings and bud wood out to northern Dade (in what became Palm Beach County in 1909 and Broward County in 1915) and south down to Homestead. Never a significant region for orange production, the major fruit trees introduced from the tropics included mango, avocado, grapefruit, and guava. Harold Dorn, who grew tropical fruit trees with his brother in Miami, recalled his arrival in the growing city and gave a narrated tour of the tropical plant industry in and around Miami in an oral 
history article for the Tequesta journal. ${ }^{34}$ The Peacock brothers, the Merricks, the Hicksons, and many more took advantage of favorable grapefruit prices, and Dade County held a complete monopoly on the early grapefruit market, with as much as a 1000 acres devoted to its cultivation. The display window of E.N. Brady's grocery store on the corner of Flagler Street and Miami Avenue regularly contained mango seedlings for sale. While many varieties were introduced from the West Indies and the Americas, including the Red Elevens, Turpentine, and Peach varieties, none produced the quality or consistency of fruit needed for predictable commercial growth. The introduction from India, the only area of the world where mango cultivation operated in an advanced state of propagation, of a variety known in India as Mulgoa but mistakenly called Mulgoba in south Florida provided the source of the most widely produced commercial variety of mango growing throughout the world today. A retired army captain from Wyoming, John Haden, saw the original Mulgoba in Palm Beach and brought a dozen of its fruits to his place south of Cocoanut Grove east of what is now Dixie Highway, and he planted the seeds from the fruit in a grove formation on his property. Haden died in 1903 before he could see what his work had done, but his wife Florence continued his work and named their variety in his honor after its first large fruiting season in 1910 (Fg. 2.5). ${ }^{35}$

${ }^{34}$ Harold W. Dorn, "Mango Growing Around Early Miami," Tequesta, Vol. 16 (1956): 37-53.

${ }^{35}$ Ibid., 43-44; see also, David Sturrock, Notes on the Mango (Stuart, FL: Stuart News, 1944) in "Fruit" Folder, Pamphlet Section "F", Charlton W. Tebeau Research Library, HistoryMiami; Robert J. Knight, Jr. and Raymond J. Schnell, 


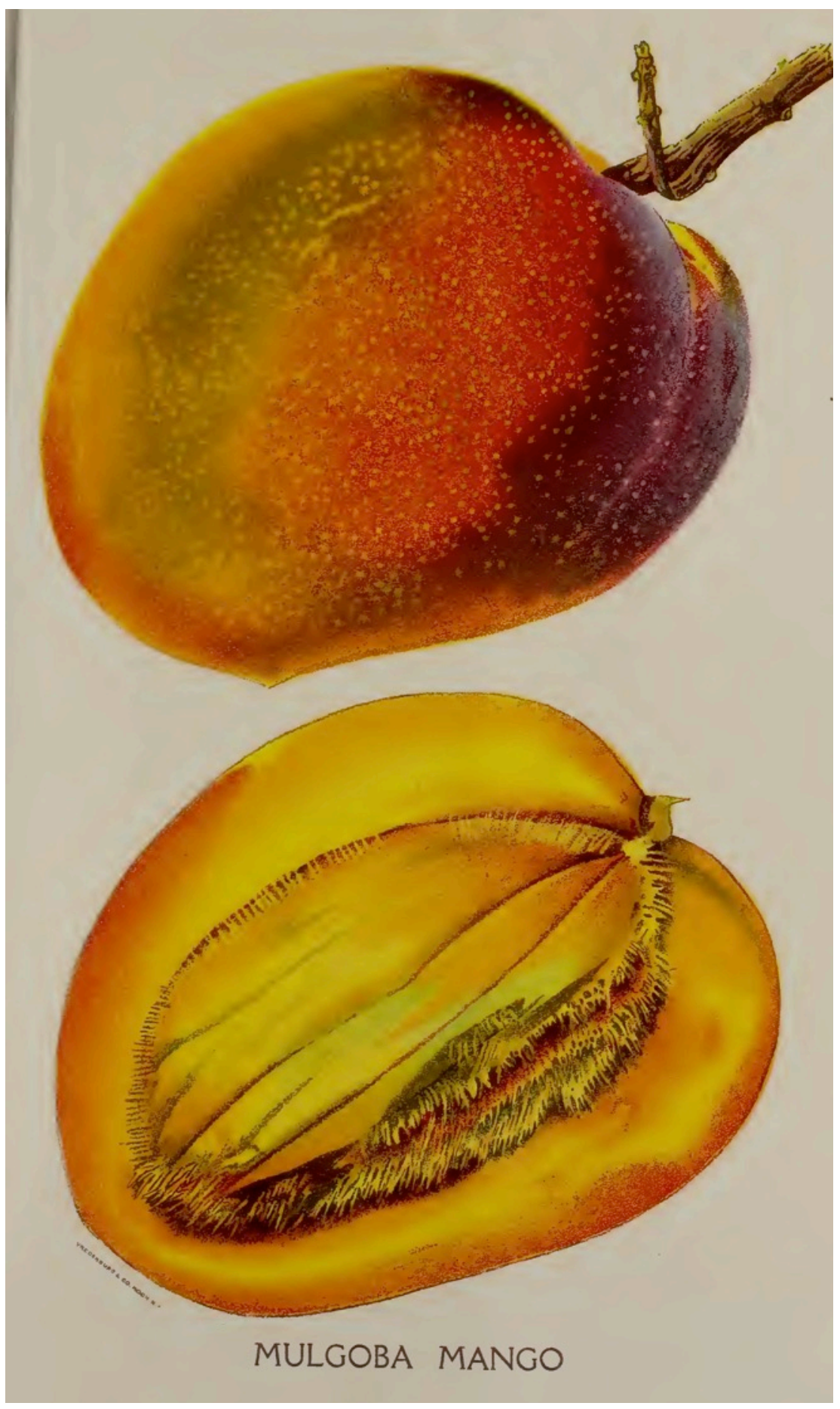

Figure 2.5 Example of Mulgoba Mango from George B. Cellon's 1907 catalogue, the origin of the Haden variety that now dominates the world's commercial market. Public domain.

"Mango Introduction in Florida and the 'Haden' Cultivar's Significance to the Modern Industry,” Economic Botany, Vol. 48, No. 2 (1994): 139-145. 
The national expansion of agricultural institutions responded to the needs of farmers, the USDA, and U.S. corporations to invest in research and development for tropical and temperate agricultural practices. The 1914 SmithLever Act, which created extension services to support the Land Grant colleges, along with the contemporary rise of 4-H clubs throughout the country, standardized production and contributed to the domestic industrial agricultural system that now proliferates and reinforced the globalization of those production standards. ${ }^{36}$ In south Florida, the Krome family established a Tropical Research and Educational Center (TREC) in partnership with the University of Florida that bolstered the region's research portfolio. ${ }^{37}$ The Brickell site reached its maximum capacity by 1914, and Charles Deering offered twenty-five acres of his Buena Vista estate, located seven miles north of the Brickell site on Miami Avenue and NE 21st Street, to extend the experiments. Deering also provided research space for the New York Botanical Garden and its director, John Kunkel Small, to grow cacti for potential use in cordage for Deering's International Harvester automatic reaper. Kunkel Small studied south Florida's tropical potential and visited there often, resulting in his Flora of Miami (1913). Popenoe and Fairchild secured a third site from Secretary of War John W. Meeks in 1920 at a decommissioned airbase south of Miami called Chapman Field, still the site of the Subtropical

\footnotetext{
${ }^{36}$ R.J. Griesbach, 150 Years of Research at the United States Department of Agriculture: Plant Introduction and Breeding.

${ }^{37}$ Campbell and Knight, Jr., "The Kromes, Pioneers in the Tropical Fruit Industry of Florida," 294.
} 
Horticultural Research Station today and only five miles from the original Perrine Grant. ${ }^{38}$

Sugar, rubber, sisal agave, grapefruit, mango, avocado, and many other tropical plant migrants grew in Miami by 1920. A great amount of labor, predominantly underpaid and overworked black American and Bahamian labor, and capital became invested into clearing the coastal mangrove hammocks, the rocky pineland, and draining the alluvial prairie Everglades for production of these and other tropical products. ${ }^{39}$ More familiar crops like tomatoes, eggplant, beans, and peppers, colloquially known as Florida's famous four, as well as fruits like strawberries, competed for land and resources with the tropical migrants. ${ }^{40}$ No significant sugar cultivation occurred until the completion of the Hoover Dike

${ }^{38}$ John Kunkel Small, Flora of Miami (New York: privately printed by author, 1913); Fairchild, "Some Plant Reminiscences of Southern Florida," 8-15; Griesbach, 150 Years of Research at the United States Department of Agriculture; for an authoritative account of International Harvester's cordage fiber operations in Mexico, see Allen Wells, Yucatan's Gilded Age: Haciendas, Henequen, and International Harvester, 1860-1915 (Albuquerque, NM: University of New Mexico Press, 1985).

${ }^{39}$ For more on the scope and significance of black labor in south Florida, see Raymond A. Mohl, "Black Immigrants: Bahamians in Early Twentieth-Century Miami," Florida Historical Quarterly, Vol. 65, No. 3 (Jan., 1987): 271-297; Howard Johnson, "Bahamian Labor Migration to Florida in the Late Nineteenth and Early Twentieth Centuries," International Migration Review, Vol. 22, No. 1 (Spr., 1988): 84-103; Zora Neale Hurston, "Florida's Migrant Farm Labor," Frontiers: A Journal of Women Studies, Vol. 12, No. 1 (1991): 199-203; Marvin Dunn, Black Miami in the Twentieth Century (Gainesville, FL: University Press of Florida, 1997); Melanie Shell-Weiss, "Coming North to the South: Migration, Labor and City-Building in Twentieth-Century Miami," Florida Historical Quarterly, Vol. 84, No. 1, Special H-Florida Issue: Florida History from Transnational Perspectives (Summer, 2005): 79-99.

40 "George Merrick's personal recollections," in Folder: 1958-003, George Merrick Papers, Box 1, 1920s-30s, Charlton W. Tebeau Research Library, HistoryMiami. 
in the 1930s to hold back the seasonal flooding from Lake Okeechobee's southern shore in western Palm Beach County, the result of which was the almost complete devastation of the Everglades and the dramatic increase in wildfires throughout the region. Other devastating environmental impacts included the Tamiami Trail and canal that effectively cut the Everglades in half. The formal establishment of Everglades National Park in 1947 only managed to save about twenty percent of the original biosphere. Further canal projects throughout south Florida irrevocably changed the landscape in favor of suburban development further and further from the shore. ${ }^{41}$

Any hints of a new proposed agricultural venture met with overzealous and many times unnecessary further land clearing, as was the case when Henry Ford planned to start a rubber plantation in the Everglades in $1924 .{ }^{42}$ Ford and Thomas Edison built their winter estates near Fort Myers on the west coast of Florida, while rubber magnate Harvey Firestone became the most famous resident of Miami Beach, the site of what Wilson Popenoe once called the largest avocado plantation on earth in $1915 .^{43}$ John Collins, the owner of the plantation, reinvented

${ }^{41}$ Gail M. Hollander, Raising Cane in the 'Glades: The Global Sugar Trade and the Transformation of Florida (Chicago: University of Chicago Press, 2008); Chris Wilhelm, "Prophet of the Glades: Ernest Coe and the Fight for Everglades National Park" (PhD diss., Florida State University, 2010); Wilhelm, "For the Birds: Challenging Wilderness in the Everglades," Journal of Environmental Studies and Sciences, Vol. 3, No. 2 (Jun., 2013): 153-166.

${ }^{42}$ Greg Grandin, Fordlandia: The Rise and Fall of Henry Ford's Forgotten Jungle City (New York: Picador, 2009), 23.

${ }^{43}$ Popenoe, Manual of Tropical and Subtropical Fruits, 24. 
his barrier island property with the help of Indianapolis capitalist Carl Fischer to create the elite winter residential community. ${ }^{44}$

Miami's USDA gardens received an average of 500 new introductions per year from its inception in 1898 through the 1950s, with over 14,000 total accessions by $1957 .{ }^{45}$ Among the over 100,000 unique introductions made nationwide during Fairchild's time as chief explorer, several shaped entire regions of U.S. agricultural production. Alfalfa from Peru, cotton from Egypt, soybeans and citrus from China and southeast Asia, durum wheat from Russia, asparagus and celery from Europe, and avocados from Mexico and Guatemala stand out as noted examples. ${ }^{46}$ Fairchild personally oversaw the reintroduction from Japan of cherry blossom trees to Maryland and Washington, D.C. in 1906, providing the source of the latter's Tidal Basin attraction. ${ }^{47}$ Miami's Brickell Avenue station received and redistributed many of these and countless other varieties of plants. After the Miami station, the USDA established stations in Savannah, Georgia, Chico,

\footnotetext{
${ }^{44}$ See Polly Redford, Billion Dollar Sand Bar: A Biography of Miami Beach (Boston, MA: E.P.Dutton, 1970).

${ }^{45}$ H.F. Loomis, "Activities of the U.S. Plant Introduction Garden," USDA Agricultural Research Service (1957).

${ }^{46}$ The inventory lists from 1898 to 1942 are digitized and available online via the Hathi Trust, accessible at: catalog.hathitrust.org/record/003975952.

${ }^{47}$ See Philip Pauly, "The Beauty and Menace of the Japanese Cherry Trees: Conflicting Visions of American Ecological Independence," Isis, Vol. 87 (1996): 51-73.
} 
California, Bellingham, Washington, and Glenn Dale, Maryland, each devoted to regionally appropriate introductions and disease prevention. ${ }^{48}$

Plant introduction in south Florida had far reaching consequences. Wilson Popenoe accepted a position as chief scientist with the United Fruit Company in 1925. He established a research university near Tegucigalpa, Honduras called the Escuela Agrícola Panamericana, now referred to as Zamorano, to train the region's agricultural producers in the proper methods learned in his years with the USDA. Popenoe trained generations of Latin Americans to be better producers for the U.S. market with support and direct interest from United Fruit. He continued to collaborate with Miami's station for disease prevention and cultivation, and he maintained correspondence with the USDA and the Florida State Horticultural Society. Popenoe also established the region's premier botanical garden in Honduras near Tela, the Lancetilla Experimental Botanical Garden. ${ }^{49}$

Fairchild retired from the USDA as head of plant introduction in 1928. He moved to Miami where he built his legacy in book form with The World Was My Garden (1938), and grew his own experimental garden, The Kampong, memorialized in his The World Grows Round My Door (1947). ${ }^{50}$ From his Miami

${ }^{48}$ Ryerson, "The History of Plant Exploration and Introduction in the United States Department of Agriculture," 8-9.

${ }^{49}$ Frederic Rosengarten, Jr., Wilson Popenoe: Agricultural Explorer, Educator, and Friend of Latin America (Lawai, HI: National Tropical Botanical Garden, 1991).

${ }^{50}$ David Fairchild, The World Was My Garden: Travels of a Plant Explorer (New York: Scribners, 1938); Fairchild, The World Grows Round My Door: The Story of the Kampong, A Home on the Edge of the Tropics (Scribners, 1947); for a 
home, Fairchild continued to oversee experimental agriculture throughout the USDA system, including in the Canal Zone. ${ }^{51}$ The years of interest and study in plant breeding contributed to Fairchild's and others' held belief in the ability to control human genes and reproduction through positive and negative eugenics. Fairchild led the American Breeders' Association, and he recommended Popenoe's brother, Paul, as the new editor of the association's Journal of Heredity. Paul Popenoe's Applied Eugenics (1918) was the most successful textbook on the subject published in the United States, which led him to become a lead figure and prolific author on the subject and related subjects such as healthful marriage ${ }^{52}$ Fairchild attempted to persuade biologist Sewall Wright of the benefits of eugenics, using his travels to Ceylon and his encounter with "halfcastes" there as examples of the impending "mongrelization" threatening American whiteness, a position Wright rejected because he did not believe enough was known regarding how to assign value to genes and thus to pursue a positive eugenics program. ${ }^{53}$

complete bibliography of Fairchild, see George H. M. Lawrence, "A Bibliography of the Writings of David Fairchild," Huntia, Vol. 1 (15 Apr 1964): 79-102.

${ }^{51}$ See, for instance, Annual Reports of the Canal Zone Experiment Gardens for Fiscal Year 1933 and 1934 (Mount Hope, CZ: Panama Canal Press, 1938).

${ }^{52}$ Alexandra Minna Stern, Eugenic Nation: Faults and Frontiers of Better Breeding in America (Berkeley, CA: University of California Press, 2015), 179181.

${ }^{53}$ William B. Provine, Sewall Wright and Evolutionary Biology (Chicago: University of Chicago Press, 1988), 180. 
Experts such as Fairchild and Popenoe, and corporations such as United Fruit, contributed to the idea, first articulated with the Monroe Doctrine, that the Caribbean and Latin America formed part of the exclusive patrimony of the United States. Imperialism operated through the acquisition of tropical plants, the development of supranational standards of tropical agriculture and medicine, the dictation by U.S. companies of favorable terms for infrastructure related to increased capacity in cash-poor producing countries, and the provision of aid and expertise geared specifically for commercial production of one or more crops intended for the U.S. market. ${ }^{54}$ Miami actively participated in this agricultural imperialism as a site of introduced tropical plant research, production, and dissemination. Journalist Samuel Crowther, a collaborator with U.S. business magnates including Harvey Firestone and Henry Ford, submitted an articulate and unapologetic argument for U.S. imperialism in the region in 1929:

In and about the Caribbean Sea a new kind of empire is rising - an empire without an emperor

\footnotetext{
${ }^{54}$ For more on the links between U.S. imperial capitalist expansion and control of tropical commodities, see The Second Conquest of Latin America: Coffee, Henequen, and Oil during the Export Boom, 1850-1930 (Austin, TX: University of Texas Press, 1997) edited by Steven C. Topik and Allen Wells; John Soluri, Banana Cultures: Agriculture, Consumption, and Environmental Change in Honduras and the United States (Austin, TX: University of Texas Press, 2005); Marcelo Bucheli, Bananas and Business: The United Fruit Company in Colombia, 1899-2000 (New York: New York University Press, 2005); Paul Gootenberg, Andean Cocaine: The Making of a Global Drug (Chapel Hill, NC: University of North Carolina Press, 2008); Greg Grandin, Fordlandia: The Rise and Fall of Henry Ford's Forgotten Jungle City (New York: Picador, 2009); Stéphanie Castonguay, "Creating an Agricultural World Order: Regional Plant Protection Problems and International Phytopathology, 1878-1939," Agricultural History, Vol. 84, No. 1 (Win., 2010): 46-73; April Merleaux, Sugar and Civilization: American Empire and the Cultural Politics of Sweetness (Chapel Hill, NC: University of North Carolina Press, 2015).
} 
[.... This empire has no sovereign. It has a leader. That leader is the United States. That leadership has been gained not by armed force, but by a power greater that can be exerted by arms - the power of mutual interest $[\ldots .$.$] The sea power of the United$ States protects this economic empire from outside interference and also, to some extent, polices within its borders. Without that power the economic development might be retarded or even demolished. But it is a protective force and not a conquering force [.... It has as its ends not a great vassalage, but a great peace and prosperity. And the gradual and involuntary forming of this empire, based on the will of no one but on the interest of everyone, is something new and amazing in the history of the world. ${ }^{55}$

The simultaneous pursuit and denial of the existence of this new empire proved one of its durable features, lending support to historical arguments both for and against its existence. ${ }^{56}$ In Miami, elites wined and dined on the fruit of this new empire as it grew around their doors. The tropical culture of Miami's elite winter residents reflected and reinforced the emergence of this new empire.

${ }^{55}$ Samuel Crowther, The Romance and Rise of the American Tropics (New York: Doubleday, Doran, and Co, 1929), 2.

${ }^{56}$ The most thorough review essay and detailed working definitions of imperial with respect to U.S. history are found in Paul A. Kramer, "Power and Connection: Imperial Histories of the United States in the World," Review Essay, American Historical Review, Vol. 116 (2011): 1348-1391; The double-move of imperial pursuit and anti-imperialism exhibited in Crowther's quoted passage is the basis for historical arguments against the U.S. as an empire, best presented by Jeremi Suri in, "The Limits of American Empire: Democracy and Militarism in the Twentieth and Twenty-First Centuries," Colonial Crucible: Empire in the Making of the Modern American State (Madison, WI: University of Wisconsin Press, 2009), 523-531, edited by Alfred W. McCoy and Francisco A. Scarano. 


\section{The Propagation of Miami’s Capitalist Tropical Culture}

The tropical culture that developed among Miami's elite domesticated and normalized the growing city's exotic appearance. Despite the fact that research done in Miami directly contributed to changes in food production and consumption on a global scale, mangos and avocados never reached critical mass for export. ${ }^{57}$ The many plant immigrants, as Fairchild always called his introductions, set down roots outside local dooryards and gardens as Miami's growing population outpaced commercial agriculture. "A flood of emigration has set in from our great cities to the country," he wrote in 1906, "and the emigrants are not poor people, nor ignorant, but are in large part the wealthy and intelligent, few of whom are willing to follow in the old ways of farming and gardening. They want something new to grow, not always because they think it will be more profitable, but because they will get more amusement out of it." ${ }^{, 58}$ Ornamental and novelty tropical gardens, amusing curiosities of idle wealth, decorated Miami’s planned communities and carried on the legacy of foreign plant introduction at the local level. ${ }^{59}$

${ }^{57}$ Carl W. Campbell, "Minor Tropical Fruit Cultivars in Florida," Florida Agricultural Experiment Stations Journal, Series No. 3724 (1970): 353-356.

${ }^{58}$ David Fairchild, "Our Plant Immigrants: An Account of Some of the Results of the Work of the Office of Seed and Plant Introduction of the Department of Agriculture and of Some of the Problems in Process of Solution," National Geographic, Vol. 17, No. 4 (1906): 181; Fairchild, "Some Plant Reminiscences," 14-15.

${ }^{59}$ For more on the domestic, residential outgrowth of tropical plant research in Florida, see Alice Smart, "Fruit Trees for Florida Homes," Department of Agriculture (Tallahassee, FL: Florida Nursery and Landscape Company, 1960), in "Fruit" Folder, Pamphlet Section "F", Charlton W. Tebeau Research Library, 
In 1925, a group of wealthy property owners on Miami Beach formed a social club called the Committee of 100 (growing to over 300 members by the 1930s), which played host in ensuing winter seasons to the largest concentration of wealth in the nation. The Committee honored Harvey Firestone in 1928 for his efforts to defeat the British rubber monopoly that forestalled American enterprise in the interwar period. Firestone received a gold medal from the Committee, and he spoke about the significant aid given by the U.S. Congress and Miami's USDA experimental gardens, in which he invested thousands, to find an independent supply of rubber. The Chapman Field research station grew the seedlings of hevea brasiliensis (Brazilian rubber trees) that Firestone then sent to Liberia, the chosen site of his rubber plantations. The British laughed at Liberia as a chosen site, but Firestone indicated to the Committee that the site had begun to show "real promise" by the time of the ceremony. ${ }^{60}$ As of 2010, Liberia's major export

HistoryMiami; and Frederic B. Stresnau, Florida, My Eden: Exotic and Native Plants for Use in Tropic and Subtropic Landscape (Port Salerno, FL: Florida Classics Books, 1986).

${ }^{60}$ Clipping from his company paper, Firestone Non-Skid, of Akron, Ohio, 25 April 1928, contained in Committee of 100 Scrapbooks 1925-29, 2007-408, Box 1, Charlton W. Tebeau Research Library, HistoryMiami. The USDA Miami Station acquired the seedlings of the Brazilian rubber tree from the British Malaysian plantation industry, possibly via David Fairchild. The drama of how rubber trees initially left the Amazon to be grown in British Malaysia receives its best treatment in Warren Dean, Brazil and the Struggle for Rubber (Cambridge, UK: Cambridge University Press, 1987), 7-23; for more on Firestone and the global production of rubber, see Mark J. Finlay, Growing American Rubber: Strategic Plants and the Politics of National Security (New Brunswick, NJ: Rutgers University Press, 2013); Stephen L. Harp, A History of World Rubber: Empire, Industry, and the Everyday (New York: Wiley-Blackwell, 2015); less about rubber and more about his business ideology can be found in Harvey Firestone and Samuel Crowther, Men and Rubber: The Story of Business (New York: Doubleday, Page, and Co., 1926). 
remained rubber, first established by Firestone in 1926 and still grown on the Firestone Natural Rubber Company plantations as well as on small landholdings. ${ }^{61}$

The Committee embodied one of several local articulations of an elite tropical culture that coalesced in the Miami area of the 1920s-1930s. Kenneth L. Roberts's Sun Hunting (1920) captured in satirical book form the ascendant tropical culture in south Florida. Roberts, a regular contributor to The Saturday Evening Post and a south Florida resident, dedicated Sun Hunting to, "Juan Ponce de Leon who found in 1513 that Florida wasn't all it was cracked up to be but who liked it well enough to go back." ${ }^{62}$ The three parts of the book addressed the native and migratory "tribes" found in south Florida, including the "time killers" of Palm Beach, the "tin-canners" of the remote interior, and the "vivacious and semi-violent peoples of Miami and its purlieus." Book Three, titled "Tropical Growth," covered Miami and some of its peculiarities. It began, "Everything grows in Florida [....] Occasionally a few things get out of hand and indulge in some over-enthusiastic growing when Florida people wish they wouldn't $[\ldots]$ This is particularly true of southern Florida $[\ldots .$.$] There are only three things that$ southern Florida has never made any effort to grow. These are mountains, snow-

\footnotetext{
61 "Rubber Production in Liberia: An Exploratory Assessment of Living and Working Conditions, with Special Attention to Forced Labor," Verité (2010).

${ }^{62}$ Kenneth L. Roberts, Sun Hunting: Adventures and Observations among the Native and Migratory Tribes of Florida, including the Stoical Time-Killers of Palm Beach, the Gentle and Gregarious Tin-Canners of the Remote Interior, and the Vivacious and Semi-Violent Peoples of Miami and Its Purlieus (Indianapolis, IN: Bobbs-Merrill, 1920), front matter.
} 
storms and earthquakes. ${ }^{, 63}$ Another chapter recounted the local impact of the USDA Subtropical Research Station without naming it directly: "There are so many different varieties of fruit that if one attempted to eat every variety in one day, he would unquestionably burst with a loud majority report." ${ }^{\text {"64 Henry }}$ Perrine's inventory lists from the 1830s first introduced many of the same fruits to the United States and to south Florida, but a century of colonial settlement, expanded state and federal institutions, and capital accumulation had to elapse to fulfill his dream of tropical Florida as enjoyed by Miami's elites. ${ }^{65}$

As prevalent as tropical fruits were locally, Roberts spent an entire chapter explaining why mango in particular never achieved national commercial success: "Miami, it appears, has a monopoly on this fruit, and the catalogues rub in the bad news by adding that 'this monopoly is not only confined to the cultivation, but also to the exquisite joy of eating it, as very few find their way to the northern markets, the local demand far exceeding the supply." ${ }^{\prime 66}$ Celebrated in Miami, the Haden mango did not consistently reach national markets until commercial

${ }^{63}$ Ibid., $125-130$.

${ }^{64}$ Ibid., 134-135.

${ }^{65}$ Ibid., 135: "A partial list of fruits which are being successfully raised in Florida's southernmost county, provided by a man with a poor memory, contains avocado - or alligator pear, custard apple, mammea [sic] apple, Jamaica apple, rose apple, Bugamot, citron, banana, Barbadoes [sic] cherry, chermoyas, cecropia, Surinam cherry, carissa, Jackfruit, lime, lemon, loquat, various sorts of mangoes, fifty-seven different varieties of orange, a number of crosses between oranges and other things, grapefruit, eggfruit, dates, olives, monsterosa deliciosa, papaya, pomegranate, Japanese persimmon, sour sop, sapote, sapodillo [sic], strawberry, tomato."

${ }^{66}$ Roberts, Sun Hunting, 156-160. 
operations exclusively sourced from the Miami varieties started in Mexico and Central America. ${ }^{67}$ The vision of Miami as a tropical commodity producer resulted instead in the exquisite joys of a local tropical culture.

Sun hunting attracted one the period's leading health advocates to open a sanitarium in the subdivision of Miami Springs. Dr. John Harvey Kellogg, a friend of Henry Ford from Battle Creek, Michigan, created a quasi-religious movement based on a grain-based diet that had many devoted followers. His Miami-Battle Creek sanitarium, begun in 1930 at Glenn Curtiss's defunct Pueblo Revival hotel in Miami Springs, offered an ideal location to pursue what he called biologic living. He told the Committee of 100 that sun, orange juice, and biologic living, the ingredients of white racial betterment, were "easily attainable" in Miami. ${ }^{68}$ Clayton Sedwick Cooper, the Committee's first president and an author of many romanticized travel accounts to Spain and Latin America, wrote in a March 21, 1927 article of Burdine's, a local periodical which advertised for a store of the same name, that, "a race of men, descendants from the old Incas,

${ }^{67}$ Robert R. Alvarez, "The March of Empire: Mangos, Avocados, and the Politics of Transfer," Gastronomica, Vol. 7, No. 2 (2007): 32; Knight and Schnell, "Mango Introduction in Florida and the 'Haden' Cultivar's Significance to the Modern Industry,"; for more on the development of the mango industry along the U.S.-Mexico border, see Alvarez, Mangos, Chiles, and Truckers: The Business of Transnationalism (Minneapolis, MN: University of Minnesota Press, 2005).

${ }^{68}$ February 26, 1935. Committee of 100 Scrapbooks, 1934-35, 2007-408, Box 8, Charlton W. Tebeau Research Library, HistoryMiami; for more on Kellogg, see Brian C. Wilson, Dr. John Kellogg and the Religion of Biologic Living (Bloomington, IN: Indiana University Press, 2014); and Ruth C. Engs, "Race Betterment" and "Race Betterment National Conference" definitions in The Progressive Era's Health Reform Movement: A Historical Dictionary (Westport, CT: Greenwood Publishing Group, 2003): 275-277. 
whose religion is largely a worship of the sun," mirrored Miami, "whose wealth, likewise, is the wealth of the sun." ${ }^{, 69}$ Miami's magic growth entirely depended on perceptions, repeated ad nauseam in local and national print media, of its climatic advantages, arguments first popularized by Henry Perrine. ${ }^{70}$ Privileged access to national media coverage set Miami apart thanks to its many leading boosters, including Committee of 100 members Cyrus H.K. Curtis of Philadelphia, who owned the Saturday Evening Post, Hugh Bancroft, president of Dow Jones and publisher of the Wall Street Journal, former Ohio governor and Miami Daily News owner James M. Cox, and Frank E. Gannett, of Gannett News Service. ${ }^{11}$

One of the Committee's most exclusive annual events centered on a private gathering at Adams Key, south of Miami. Carl Fischer, the major capitalist behind Miami Beach's transformation into an elite winter haven, developed a yacht club on Adams Key to celebrate the tropical escapism offered in south Florida and opened it to his wealthy friends and neighbors by 1922 . Named after a variety of seagrape endemic to the Keys and the Caribbean, Cocolobo Cay Club's annual retreat received national media coverage. The event was "marked by informality" and, in the context of the nation's economic woes, the buffet lines were mockingly referred to as "bread lines." "Negro entertainers,"

${ }^{69}$ Clayton Sedwick Cooper, Burdine's, March 21, 1927, in Committee of 100 Scrapbooks 1925-29, 2007-408, Box 1, Charlton W. Tebeau Research Library, HistoryMiami.

${ }^{70}$ See, for instance, Victor Rainbolt, The Town that Climate Built: The Story of the Rise of a City in the American Tropics (Miami: Parker Art, 1925); and the promotional literature of George Merrick's Coral Gables, such as The Story of Coral Gables (Miami: Parker Art Printing, 1926).

${ }^{71}$ Committee of 100 Scrapbooks, 1931-32, 2007-408, Box 5. 
never named, acted out all manner of Noble Savage performances for the white millionaires in attendance, including shirtless wrestling and simulated "walking the plank" reenactments, ironically because Adams Keys was believed to be the base of a seventeenth-century black pirate discussed briefly in chapter one, the Black Caesar. Reports estimated the accumulated wealth of the gathering at north of $\$ 500$ million, with more than half of that likely constituted by Firestone's immense fortune. ${ }^{72}$ Private yachting culture expanded greatly among elites at the time, with families like the Mellons and Vanderbilts beginning and ending their annual winter trips to the Caribbean and Europe from Miami's harbors. The Biscayne Bay Yacht Club, an important early civic institution, fostered and supported interest in the exclusive form of leisure travel. ${ }^{73}$

In 1930, another noted annual winter tradition that celebrated the tropical side of life began on Miami Beach. Spearheaded by Miami Beach Garden Club President Leticia Southerland, the annual Tropical Flower Show featured orchids and other tropical flowers sourced from throughout the Caribbean and Latin America. Southerland, whose husband J. Julien was a respected judge in north Miami Beach's Bal Harbour Village, traveled throughout the region in search of the best specimens to display at her show, and she established friendly contacts and generated interest in the show and in the city of Miami among Latin American and Caribbean reading publics. Deemed "flower diplomacy" by her

\footnotetext{
${ }^{72}$ Various news clippings, Clayton Sedwick Cooper Scrapbook, Fall 1928Spr.1929, Committee of 100 Scrapbooks, 2007-408, Box 1, Charlton W. Tebeau Research Library, HistoryMiami.

${ }^{73}$ See Biscayne Bay Yacht Club records, 1909-1970, Charlton W. Tebeau Research Library, HistoryMiami.
} 
supporters, Southerland's international botanical outreach received glowing praise and privileged support from leaders of government, science, and industry as the era of Good Neighbors began in earnest. Secretary of Agriculture Arthur M. Hyde annually lifted the ban on cut flowers to allow Southerland to import orchids to Miami. ${ }^{74}$ She traveled extensively in 1931 and in subsequent years, and coverage of her trips in the local papers on her route suggested the receptive attitude to her endeavor (Fg. 2.7) ${ }^{75}$

During her 1931 trip, Southerland managed to convince Argentine officials, through her contact with U.S. Ambassador to Buenos Aires Robert Wood Bliss, to officially name the ceibo* tree, native to Argentina, as the national tree. Dr. Carlos D. Storni, Argentina's general director of agriculture, sent Southerland a copy of the tree's official designation as the national tree. She also managed to secure the export of the first ever specimen allowed out of the country and planted it on Miami Beach (Fg. 2.6). After the 1933 show, Southerland wrote Guatemalan President Jorge Ubico Castañeda to thank him for his support of the

${ }^{74}$ The historical context of flower bans and restrictions on other imported biological material is found in Peter Coates, American Perceptions of Immigrant and Invasive Species: Strangers on the Land (Berkeley, CA: University of California Press, 2007).

${ }^{75}$ Southerland's itinerary: Jamaica; Port-au-Prince, Haiti; St. John's, Antigua; Georgetown, British Guyana; Para, Fortaleza, Bahia, Río de Janeiro, and Porto Alegre in Brazil; Buenos Aires, Argentina; Santiago and Antofosgasta, Chile; Lima, Peru; Santa Elena, Ecuador; La Guaira and Maracaibo, Venezuela; Barranquilla, Colombia; Cristóbal, Canal Zone; San José, Costa Rica; San Salvador, El Salvador; Guatemala City, Guatemala; Merida and Mexico City, Mexico; and ended in Havana, Cuba, before heading back to Miami. Coverage included La razón, El mundo, and La palabra (Buenos Aires); Haiti-Journal (Port-au-Prince); Kingston Daily Gleaner (Kingston); El comercio (Lima), and others. Southerland Family Papers, 1931-62, Box 2, 1993-326-327 and 1993-411, Charlton W. Tebeau Research Library, HistoryMiami. 
show and to suggest that the "White Nun" (monja blanca) variety of orchid sent to the show be named the national flower of Guatemala. The next day the Guatemalan Congress approved her request. In Lima in 1933, Southerland visited the garden, named "La moda elegante" (elegant fashion), of Dr. José Francisco Ruíz, who informed her with regret that his best orchid specimens bloomed from May to October and so could not be included in the show's March-April run that year, but he promised to work on adjusting their blooming schedule so that they could be included in future years. Among the many supporters of the show in Miami were David Fairchild, John Kunkel Small of the New York Botanical Garden, and Charles Torrey Simpson. The President of New York City's Pan American Society, John L. Merrill, officiated the show on Southerland's behalf. ${ }^{76}$ Southerland's "Inter-American Bridge of Flowers" long outlasted her own life, and the annual Orchid Show continues each year at Fairchild Gardens in Coral Gables, likewise the home of the American Orchid Society. Her work signaled Miami's increasing visibility in Latin America and the Caribbean, also aided by the city's burgeoning airline travel to the region. Southerland's ability to acquire exotic plant specimens in Latin America destined for Miami positioned her in the company of Henry Perrine, Wilson Popenoe, and others who helped shape Miami's tropical landscape and culture.

\footnotetext{
${ }^{76}$ Clarissa Greene, "Inter-American Bridge of Flowers," All Florida Magazine, Vol. 6, No. 1 (June 1931): 13, 19, in Southerland Family Papers, 1931-62, Box 2, 1993-326-327 and 1993-411, Charlton W. Tebeau Research Library, HistoryMiami. *Some coverage mistakenly referred to the ceibo tree as a ceiba tree, a different and far more prodigious plant migrant in Miami, whose aboveground root system and wide canopy now decorates the boulevards of Coral Gables. The ceibo, also spelled seibo, is a flowering tree now considered the national flower, not the national tree, of Argentina.
} 


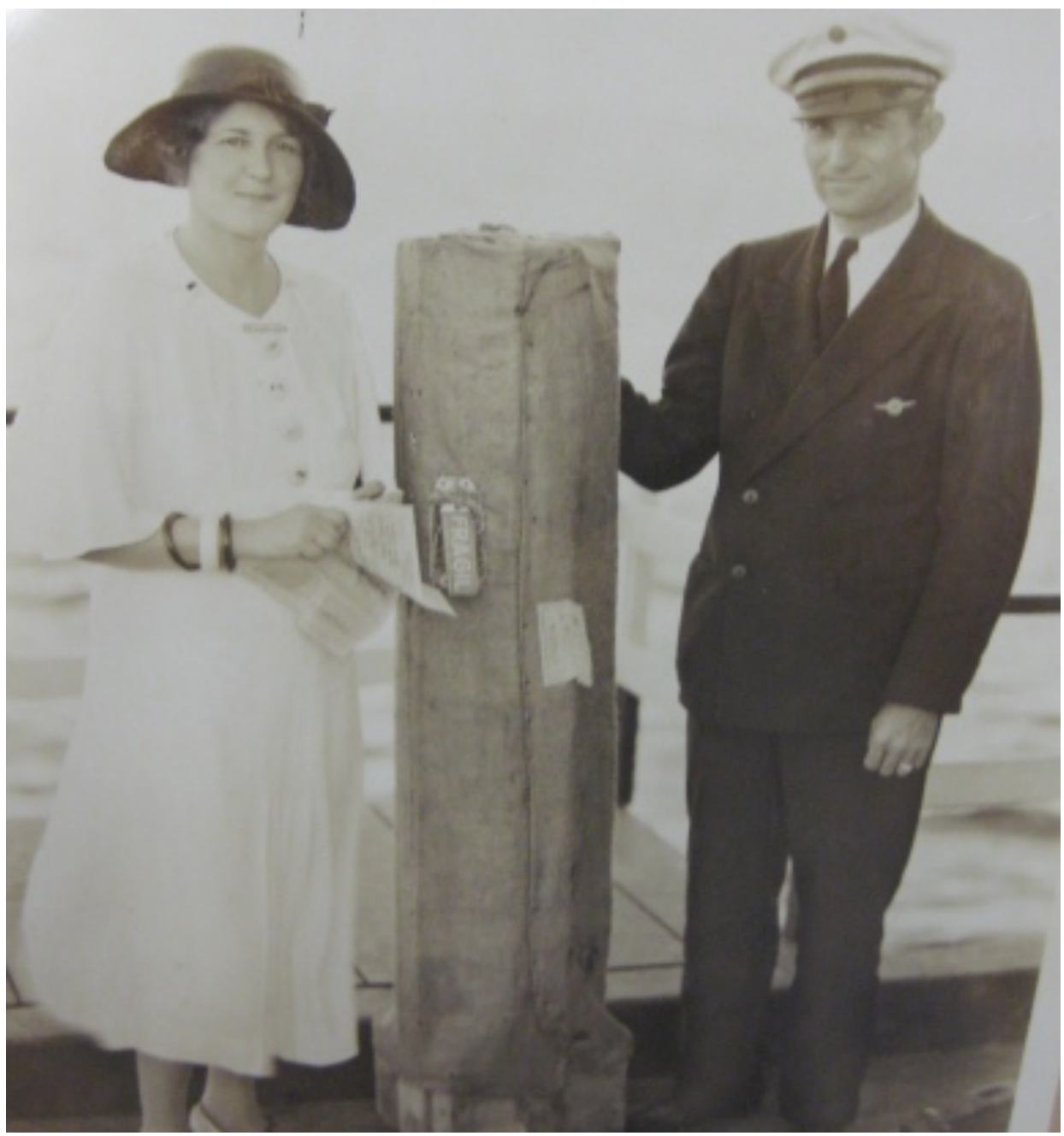

Figure 2.6 Leticia Southerland (left) and unnamed port inspector at Miami receiving the packaged ceibo tree from Argentina via PanAm airmail (undated, but possibly 1933). Copied with permission from Southerland Papers, HistoryMiami. 


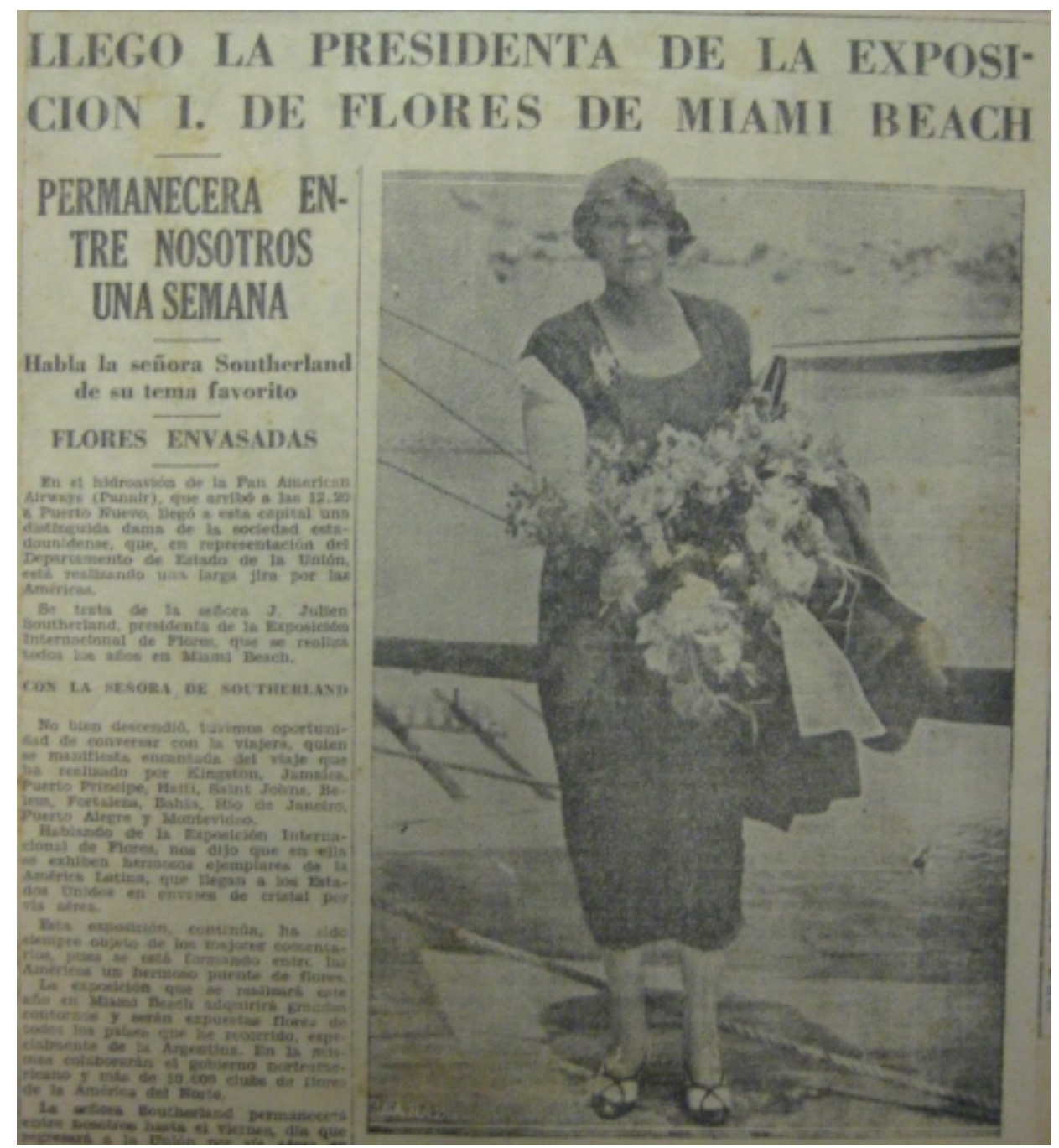

Figure 2.7 Example of Southerland's media coverage in this January 27, 1933 edition of $\mathbf{L a}$ razón in Buenos Aires. Copied with permission from Southerland Papers, HistoryMiami.

\section{Charles Torrey Simpson's Conflicted Naturalism}

Miami's celebrated tropical culture was not without its critics. Charles Torrey Simpson, a largely self-taught naturalist from Illinois who specialized in the study of snails (conchology), published several significant articles and books during his more than thirty years living and working in what he called Lower Florida. Not interested in the applicability of plants for commercial production, Simpson's brand of naturalism existed somewhat at odds with the commodity- 
oriented versions exhibited by Fairchild, Popenoe, and capitalists like Firestone and Charles Deering, though Simpson thanked the latter for his support in one of his books. Fairchild himself came to regret contributing to the rapid suburban development of south Florida, but he never exhibited the level of opposition that Simpson maintained. Simpson informed a generation of Miamians about the need to intrinsically value the natural environment, and advocated for the establishment of the Everglades National Park. Despite his stated opposition to commercialism of any kind, Simpson informed Miamians about tropical landscape architectural standards, with much of his suggested plant material stemming from the very same commercial work of the USDA and the Miami experimental gardens. This internal conflict between conservation and a landscape design aesthetic derived from tropical plant migrants never dawned on Simpson or his biographers. ${ }^{77}$ Simpson's visionary conservationism still harbored dominant notions of conquering nature and making Miami tropical through his landscape design aesthetic and years of public education.

His first book, Ornamental Gardening in Florida (1916), illustrated the conflicted discourse of exotic plant material usage while maintaining a sense of appreciation for the untouched landscape. In the introduction, Simpson seemed to share unabashedly the excitement about newly introduced plants in the hands of

\footnotetext{
${ }^{77}$ Narratives of Simpson focus exclusively on his uniqueness as a conservationist and fail to highlight the irony that he was a proponent of using exotic plants to decorate Florida homes. For an otherwise excellent biography that privileges Simpson's conservation, see Elizabeth Ogren Rothra, Florida's Pioneer Naturalist: The Life of Charles Torrey Simpson (Gainesville, FL: University Press of Florida, 1995); and likewise in Leah La Plante, "The Sage of Biscayne Bay: Charles Torrey Simpson's Love Affair with South Florida," Tequesta, Vol. 1, No. 3 (1995): 61-82. La Plante seems to just barely miss this tension.
} 
the plant explorers and experimental gardeners of Miami: "We can scarcely form the faintest conception of the enormous number of useful and ornamental trees and plants from the warmer parts of the world which will grow within the limits of this state. ${ }^{, 78}$ His vision for the future of Miami, too, appeared strikingly nonconservationist: "I can look forward with full confidence to a time in the near future when a large area within the territory covered in this work will be girdled with the finest roads bordered with beautiful tropical and semi-tropical shade trees; I can see the land filled with happy homes shaded and embowered with the glorious vegetation of the equatorial regions, a land of peace and contentment, a land of hope, of rest for the weary, a land of perennial verdure and fadeless beauty., 79

In the first chapter, titled "Laying out Grounds and Clearing Land," Simpson gave detailed instructions on how to clear out the native plants found in south Florida while at the same time advocated for the conservation of the hardwood hammocks found along the coast:

I wish it were in my power to persuade my readers who come into possession of such land to leave this glorious vegetation just as nature has created it. The small remnant of this untouched beauty is fast disappearing before the settler's fire and ax and especially before the real estate man. Mankind everywhere has an insane desire to waste and destroy the good and beautiful things that nature has

\footnotetext{
${ }^{78}$ Charles Torrey Simpson, Ornamental Gardening in Florida: A Treatise on the Decorative Plants Adapted to Florida and their Cultivation, with Suggestions for the Ornamentation of Florida Homes and Grounds (Little River, FL: Printed by the author, 1916), $\mathrm{x}$.

${ }^{79}$ Ibid., xiii.
} 
lavished upon him [....] Here in South Florida we have a lot of men who buy up land, clear off the vegetation, lay it out into lots and sell it. It seems to be their especial delight to get hold of hammock, put in a gang of ignorant Negroes, and utterly destroy the beautiful growth that it has taken centuries to create. ${ }^{80}$

Later, in a chapter titled, "The Cultivation and Care of a Garden,"

Simpson suggested that, although rapid changes to the landscape resulted from this "insane desire to waste and destroy," incremental changes, which over time amounted to the same environmental destruction, were preferable: "If one must make his home in the hammock I would advise that he cut out as little of it as possible, and that what he does cut should be done gradually [...] One can plant exotic things from time to time as he takes out the native growth."

No doubt Simpson advocated for the more cautious growth of Tropical Miami, and certainly he loved nature: "When I am lonely and depressed I wander down into it [the partially-conserved hammock] to be alone with nature, to get away from the artificialities and annoyances of civilization, to let myself become a part and parcel of it all. I feel that the dear trees are my friends and comforters; I can take counsel with them and trust them; and I always come back to the world and its duties strengthened and refreshed." ${ }^{, 82}$ But what was lost even on Miami’s most revered naturalist was that human activity, the stuff of History, shaped Miami into a tropical city. Simpson often conflated "native" and "naturalized"

\footnotetext{
${ }^{80}$ Ibid., 3-4.

${ }^{81}$ Ibid., 41.

${ }^{82}$ Ibid., 83.
} 
plant species, for example in the chapter titled, "Catalog of Indigenous and Naturalized Plants," because the latter's widespread growth hid the fact that the vast majority were either intentionally or surreptitiously introduced. His section on "Native Palms" recounted over sixteen varieties that were not native but rather, in his own words, "naturalized." 83

Simpson's other great work, In Lower Florida Wilds (1920), lamented at the outset the fact that, "To-day most of its hammocks are destroyed, the streams are being dredged out and deepened, the Everglades are nearly drained; even the pine forests are being cut down, ${ }^{, 84}$ but Simpson never fully self-reflected on the fact that he advocated as much as anyone for the introduction and proliferation of non-native plants over and above the preservation of the "wilds" he saw disappearing. Even as he argued for natural versus formal gardening and for the conservation of what nature had bestowed wherever possible, Simpson's work abstracted and reified the processes of drastic environmental change in which he took a central, if only semi-willing role. Coconut palms and mangos were only as real and natural to south Florida as the roads and buildings Simpson proposed for them to decorate.

If there is a lesson or moral to draw from Simpson, it is that humans only have limited control over the long-term, unintended consequences of a planted

${ }^{83}$ Ibid., 97; for a further exhibition of this conflated narrative style, see Charles T. Simpson, "Native and Exotic," Proceedings of 25th Annual Meeting of the Florida Horticultural Society (1912): 166-207.

${ }^{84}$ Charles Torrey Simpson, In Lower Florida Wilds: A Naturalist's Observations on the Life, Physical Geography, and Geology of the More Tropical Part of the State (New York: Putnam, 1920), v. 
palm tree. The built environment that grew up in the shade and embraced by the tropical splendor of the city's plant migrants, the other demonstrable and enduring measure of "magic" growth, is the subject of Chapter 3.

\section{Conclusion: Continued Tropical Research and The Questionable Legacy of}

\section{Plant Immigrants}

The USDA Subtropical Horticultural Research Station (known simply as the Miami Station) continues the work Henry Perrine initiated now almost two centuries ago, and only at a five-mile distance from where he intended to make good on his Tropical Plant Company. By the 1970s, the Miami Station shifted its focus from introduction to tropical plant disease prevention as well as to the cataloging and retention of proven germplasms. ${ }^{85}$ Two diseases related to orange growing, citrus canker and citrus greening, continue to occupy much of the research conducted at the Miami Station and the University of Florida's south Florida research facilities. Another recent concern is the increasing presence of diseases that affect the cacao trees, the source of chocolate. Seventy percentage of the global production takes place in West Africa in countries like Côte d'Ivoire, a neighboring country of Firestone's Liberian rubber plantations. Mars, one of the world's largest chocolate manufacturers, invested millions of dollars in the Miami station in 2008 to secure genome sequences intended to better cultivate the tree

${ }^{85}$ R.J. Griesbach, 150 Years of Research at the United States Department of Agriculture: Plant Introduction and Breeding; for more on the history and political implications of germplasm retention, see the collected essays in Seeds and Sovereignty: The Use and Control of Plant Genetic Resources (Durham, NC: Duke University Press, 1988), edited by Jack R. Kloppenburg, Jr. 
and prevent diseases. Dr. Ray Schnell, formerly the Supervisory Research Geneticist at the Miami Station, joined Mars full-time in 2012 as the Global Chocolate Director of Cacao Plant Science. ${ }^{86}$ The interaction and mutual dependence of capital and state institutions continues to be as significant today for Mars as it was a century ago for the Deering Brothers, Harvey Firestone, Henry Ford, and others in relation to the USDA Miami gardens. Schnell's move to Mars from the USDA is also reminiscent of Wilson Popenoe leaving the USDA to join United Fruit. Patterns and problems of global agricultural production suffused Miami's history for over a century, and its active role in shaping and sustaining global food production continues.

The thousands of introduced tropical plants to Miami received more critical appraisal beginning in the mid-twentieth century, including the air potato plant and the Brazilian pepper plant. ${ }^{87}$ Chief among researchers with a more critical stance regarding introduced plants was Julia F. Morton, a self-taught botanist who taught at the University of Miami from the 1940s to the 1980s. Morton prodigiously wrote about the invasive characteristics of many introduced

${ }^{86}$ Corporate Press Release for North America, "Mars, USDA-ARS, and IBM Unveil Preliminary Cacao Genome Sequence Three Years Ahead of Schedule," September 2010, accessible via www.mars.com.

${ }^{87}$ Some authoritative accounts of the problem of invasive plants and proposed solutions include Strangers in Paradise: Impact and Management of Nonindigenous Species in Florida, edited by Daniel Simberloff, Donald C. Schmitz, and Tom C. Brown (Washington, DC: Island Press, 1997); and Filling in the Gaps: Ten Strategies to Strengthen Invasive Species Management in Florida (Washington, DC: Environmental Law Institute, 2004); see also, Sharon M.L. Ewe, et al., "Foreign Exploration for Biological Control Agents of Three Invasive Plant Species from Asia," Wildland Weeds (Fall, 2006): 19-21. 
plants and became a lead figure in south Florida engaged in combatting the legacy of USDA tropical plant introductions. ${ }^{88}$ Morton helped found the Economic Botany journal, whose stated mission is to research the use of plants by people, and she led information campaigns about poisonous plants for area hospitals, schools, and ranches. ${ }^{89}$ Edward O. Wilson, a distinguished biologist and scientist of ants (myrmecology), neatly summarized the more critical view toward introduced tropical plants held by Morton and others in his forward to Strangers in Paradise, a fitting conclusion to this chapter: "Parts of South Florida look good to the uninitiated, I grant, but in the naturalist's eye it is substantially a Potemkin facade of foreign species [....] A precious and irreplaceable part of Florida's, and the nation's, heritage is disappearing [....] What is being gained in their place? A hodgepodge of species found in other parts of the world [....] Florida is being homogenized, and everyone, for all time to come, will be the poorer for it." 90 Wilson, like the other more recent critics of plant immigrants, stands in vocal opposition to a historical process of environmental change first initiated with earnest by Henry Perrine in the 1830s. Acknowledgment and serious analysis of that historical process, as found in this chapter, aids and informs the work of

${ }^{88}$ See, for instance, Julia F. Morton, "Pestiferous Spread of Many Ornamental and Fruit Species in South Florida," Proceedings of Florida State Horticultural Society, Vol. 89 (1978): 348-353; and Morton, "No One Loves the Bischofia Anymore," Proceedings of the Florida State Horticultural Society, Vol. 97 (1984): 241-244.

${ }^{89}$ Henry Fountain, “Julia Morton, 84, An Expert of Florida's Poisonous Plants," Obituary, New York Times, September 14, 1996.

${ }^{90}$ Edward O. Wilson, "Forward," Strangers in Paradise, ix-x. 
avoiding future mistakes and further degradation of south Florida's, and the nation's, environmental heritage. 


\section{CHAPTER III}

\section{"Ages-Old Material Taking on New Forms": The Aesthetics and Consequences of Capitalist Suburban Development}

Developers, architects, city planners, artists, and laborers involved in Miami's development, like the many plants used to decorate the city, arrived from somewhere else. Because it was a new urban space forged out of a frontier wilderness, Miami lacked a civic history from which to draw direct inspiration. The Spanish past of Florida, celebrated by Miami's elites, provided the natural solution. Model Spanish revival suburbs, however, created new problems of metropolitan management and civic responsibility that challenged the wisdom of planned community development. The advent of the automobile and adequate space to expand contributed to a fractured civic landscape in which a network of competing elite, single-class communities pursued lives of pleasure and selfserving morality while being supported and cared for by increasingly isolated and disorganized working class fringes.

Writings by George Merrick, his art advisers, and interested observers of Coral Gables help explain the choice of Spanish revival architecture as the dominant aesthetic for Miami's suburban growth. ${ }^{1}$ Firsthand accounts of Miami's 1920s real estate boom and bust detail the causes and outcomes of speculative

${ }^{1}$ The Story of Coral Gables (Miami: Parker Art Printing, 1926); "Millions of Capital Drawn to Miami," The New York Times, Mar. 15, 1925, 1-2; Marjory Stoneman Douglas, Coral Gables: America's Finest Suburb, Miami, Florida (Miami: Parker Arts Printing, 1926). 
development. $^{2}$ Miami's boom and bust prefigured both the Great Depression and the mid-century suburbanization of cities across the country. ${ }^{3}$ Unimaginable valuations for land provided a false sense of security and permanency for the nation's investors in Miami prospects. Optimism in investment mirrored an outlook of future greatness for the city. Miami's unwavering orientation toward the Caribbean and the Americas cemented the appropriateness of Spanish design fantasies. The appropriated tradition of Spanish architecture built of concrete and iron suggested the durability of the endeavor. Purchased building materials from crumbling edifices throughout the region and Europe concealed the illusion of authenticity. ${ }^{4}$ Eventual transitions to modernist clean lines and functionality coexisted with, but never fully replaced, the appeal of Spanish revivalism.

2 Theyre Weigall, Boom in Florida (London: Bodly Head Limited, 1931) printed in the U.S. as Boom in Paradise (New York: A.H. King, 1931); Kenneth Ballinger, Miami Millions: The Dance of the Dollars in the Great Florida Land Boom of 1925 (Miami: Franklin Press, 1936); Aretta L. Semes, "From Rising Sun to Daunting Storm: Miami in Boom and Bust, A Reminiscence," Tequesta, Vol. 58 (1998): 91-110.

${ }^{3}$ Frank B. Sessa, "Miami in 1926," Tequesta, 16 (1956): 15-35; Paul S. George, "Brokers, Binders, and Builders: Greater Miami's Boom of the Mid-1920s," Florida Historical Quarterly, 65 (July 1986): 27-51; Raymond B. Vickers, Panic in Paradise: Florida's Banking Crash of 1926 (Tuscaloosa, AL: University of Alabama Press, 2007); Barbara Miller Lane, Houses for a New World: Builders and Buyers in American Suburbs, 1945-1965 (Princeton, NJ: Princeton University Press, 2015).

${ }^{4}$ Beth Dunlop, "Inventing Antiquity: The Art and Craft of Mediterranean Revival Architecture," The Journal of Decorative and Propaganda Arts, Vol. 23, Florida Theme Issue (1998): 190-207; Nicholas N. Patricios, "Phineas Paist and the Architecture of Coral Gables, Florida," Tequesta, 64 (2004): 5-27; Margot Ammidown, "Walter DeGarmo: Fantasies in Concrete," Update, Vol. 11, No. 1 (Feb. 1984): 3-6; Jose M. Lozano, "The Last Eclectics: Walter DeGarmo and Richard Kiehnel in South Florida," Southeastern College Art Conference Review (1990): 363-371; Maurice Culot and Jean-Francois LeJeune, Miami: Architecture 
Section one examines the early built traditions in Miami prior to 1920.

Black Bahamians brought with them the techniques required to effectively use the local limestone in residential and commercial construction, learned and widely used by early lead architects Walter DeGarmo and August Geiger. Some winter estates of major capitalists in Miami built before 1920 featured Spanish design elements, but less committedly so than after 1920. Section two covers the suburbanization of the 1920s and the more consistent use of Spanish design. Rampant speculation in land values during the 1920s incentivized more and more subdivisions to be built, often under less scrupulous terms than the leading example of Coral Gables. A series of events that included a severe hurricane ended the real estate boom and financially ruined many investors. The final section assesses the legacy of suburban development and the problems it caused relating to municipal governance and the provisioning of community services. Innovative solutions of metropolitan-wide governance resulted in the 1950s.

\section{Rediscovering a Spanish Past: Origins and Iterations of an Appropriated} Style

As we saw in Chapter 1, Spain's colonial legacy in Florida framed the meaningful articulation of U.S. sovereignty over the territory by lawmakers and settlers beginning with the initial transfer of ownership in 1821. The remaining structures of old Saint Augustine provided the archaeological inspiration for a

of the Tropics (New York: Princeton Architectural Press, 1993); Hap Hatton, Tropical Splendor: An Architectural History of Florida (New York: Alfred A. Knopf, 1987); Donald W. Curl, "The Florida Architecture of F. Burrall Hoffman Jr., 1882-1980," Florida Historical Quarterly, 76 (1998): 399-416. 
regional vernacular architecture in Florida that linked the Spanish past with the U.S. present and envisioned future. Henry Flagler's Ponce de Leon hotel, a Victorian structure with Spanish Renaissance facades, demonstrated the potential value of such gestures to a Spanish past. ${ }^{5}$ His $\$ 20,000$ investment in the commission to design and exhibit a Florida building at the 1893 World's Columbian Exposition in Chicago, a result of multiple failed attempts to garner public funds for the endeavor, carried Florida's Spanish revivalism to a national stage for the first time. The building was a wood-framed copy of the Castillo de San Marcos, completed in 1695 and renamed Fort Marion after U.S. territorial control, with a thin veneer of plaster cover to complete the faux-mason appearance. ${ }^{6}$ One observer remarked that the Florida building was "distinctly southern in idea, characteristics, and material. The design is unique, original, and historic." " By "southern" the observer meant Spanish, a conflation of geography and history that many readers would have understood. The design was neither unique nor original, but its historic value as Spanish helped Florida's promoters present a unified identity for the state to the national public.

\footnotetext{
${ }^{5}$ Reiko Hillyer, "The New South in the Ancient City: Flagler's St. Augustine Hotels and Sectional Reconciliation," Journal of Decorative and Propaganda Arts, Vol. 25, The American Hotel (2005): 104-135.

${ }^{6}$ Stephen Kerber, "Florida and the World's Columbian Exposition of 1893," Florida Historical Quarterly, 66 (Jul., 1987): 25-49; Joel M. Hoffman, "From Augustine to Tangerine: Florida at the U.S. World's Fairs," Journal of Decorative and Propaganda Arts, Vol. 23, Florida Theme Issue (1998): 48-85.

${ }^{7}$ The World's Columbian Exposition, Chicago, 1893: A Full Description of the Buildings and Exhibits in All Departments, Edited by Trumbull White (Chicago and Philadelphia: International Publishing, 1893), 506.
} 
Builders and promoters of many southern states and territories, from Florida to California, appropriated an imagined and real legacy of the Spanish colonial period as a means of legitimating and naturalizing dense settlement in sparsely populated frontiers. Furthermore, the World's Columbian Exposition, originally slated for 1892 to celebrate the four-hundredth anniversary of Columbus, suggested that the romance of Spain's colonial past in the Americas was not confined to the former Spanish possessions at the nation's southern borders. By the late-nineteenth century, cities like Saint Augustine, Santa Fe, and Los Angeles saw in the Spanish past a means of achieving a unified vision for their respective cities' Anglo-American futures, in the latter cases at the expense and exclusion of large populations of resident Mexicans and Pueblos. ${ }^{8}$ South Florida lacked evidence of a Spanish presence, real as it once was, and architectural experimentation at the beginning of the twentieth century at first drew widely from various styles before a predominant Spanish revival style coalesced by 1920 .

Elite residents first experimented with elements of a Spanish aesthetic even before the city's founding in 1896, along with practices of using local building materials less specific to style. Julia Tuttle's renovation of her newly

\footnotetext{
${ }^{8}$ Reiko Hillyer, "The New South in the Ancient City: Flagler's St. Augustine Hotels and Sectional Reconciliation," Journal of Decorative and Propaganda Arts, Vol. 25, The American Hotel (2005): 104-135; Chris Wilson, The Myth of Making Santa Fe: Creating a Modern Regional Tradition (Albuquerque, NM: University of New Mexico Press, 1997); William Deverell, Whitewashed Adobe: The Rise of Los Angeles and the Remaking of its Mexican Past (Berkeley, CA: University of California Press, 2005); David J. Weber, The Spanish Frontier in North America (New Haven, CT: Yale University Press, 1992), 243-264.
} 
purchased Fort Dallas property in 1893, with salvaged Spanish tiles from a shipwreck in Biscayne Bay used as her main floor material, marked the first inkling of a pattern of appropriated Spanish materials for Miami architecture. ${ }^{9}$ Other early structures in south Florida, such as Coconut Grove pioneer Ralph Munroe's Barnacle House, illustrated the utility and novel appearance of local limestone as a distinguishable building material. The porous character of the limestone and the prevalence of marine fossils in its bedrock looked remarkably similar to submarine coral formations, and so the material was, and continues to be, mislabeled as coral rock. The Barnacle House also demonstrated the direct influence of black Bahamian migrants to the Grove. More than any other segment of the growing Miami population, black Bahamians provided the knowledge of how to use the limestone for residential and commercial construction. "These negroes," wrote George Merrick, founder of Coral Gables, "had built their homes in their own islands of the Coral rock, and they brought here their skill in masonry building $[\ldots .$.$] This knowledge of building with the native coral limestone came$ with Bahaman negroes, as did so much other valuable knowledge and experience in the building of walls, roads, other uses of the cora; and use of the land and sea." ${ }^{10}$ Merrick and his contemporary suburban planners relied heavily on Bahamian labor. By 1920, the black Bahamian population of Miami and its

\footnotetext{
${ }^{9}$ Nathan D. Shappee, "Fort Dallas and the Naval Depot on Key Biscayne, 18361926," Tequesta, 21 (1961): 35.

${ }^{10}$ George E. Merrick, "Pre-Flagler Influences on the Lower Florida East Coast," Tequesta, 1 (1941): 5.
} 
neighboring communities of Lemon City, Cutler, Perrine, and Coconut Grove totaled over 4,000 , constituting more than half of the resident black population. ${ }^{11}$

Walter DeGarmo, one of Miami’s first major architects, no doubt drew inspiration from the limestone construction of Coconut Grove. DeGarmo, whose father Charles previously served as president of Swarthmore College in Pennsylvania and then Cornell University in New York, was persuaded to move to Coconut Grove in 1903 with his family at the request of a botany professor and family friend at Cornell, John Gifford, who had taken up residence near Munroe. Walter, a graduate of civil engineering at Swarthmore and architecture at Cornell, left a lucrative draftsman position at the New York City architectural firm of John Russell Pope to join his father in Miami, and he set up his own architectural firm in downtown Miami on Avenue C. From Russell Pope DeGarmo learned the fundamentals of Beaux-Arts design, and such training provided the basis for the Spanish revival style that later characterized his work. DeGarmo's early commissions for Miami, including the original Miami City Hall and police station (1910s), and McAllister Hotel (1917), more closely resembled the exterior ornamentation of Beaux-Arts than a specific Spanish style, only fully realized with his work in Coral Gables in the 1920s. Southeasterly exposure more than anything else guided his design philosophy in his early Miami years, according to

\footnotetext{
${ }^{11}$ Raymond Mohl, "Black Immigrants: Bahamians in Early-Twentieth Century Miami," Florida Historical Quarterly, Vol. 65, No. 3 (Jan., 1987): 271-297; Howard Johnson, "Bahamian Labor Migration to Florida in the Late Nineteenth and Early Twentieth Centuries," International Migration Review, Vol. 22, No. 1 (Spr., 1988): 84-103; Melanie Shell-Weiss, "Coming North to the South: Migration, Labor and City-Building in Twentieth-Century Miami," Florida Historical Quarterly, Vol. 84, No. 1 (Summer, 2005): 79-99.
} 
his son Kenneth. Prior to the invention of electrical air conditioning, a design imperative meant to shield the afternoon sun's extremes from the west as well as south Florida rains figured prominently for DeGarmo and others. ${ }^{12}$

Charles Deering's Buena Vista estate, completed in 1912, represented an early local example of Spanish architecture. The estate, designed by New York architect Clinton McKenzie who subsequently contributed such outstanding local examples of Spanish design as the Plymouth Congregational Church (1917), reflected Charles Deering's lifelong fascination with all things Spanish. ${ }^{13}$ An avid collector of Spanish art, Charles built a castle in Sitges, south of Barcelona, called Palacio Maricel, contemporary to his estate in Buena Vista, where he intended to house his collection of art. Deering's friendship with Catalán artists Ramón Casas i Carbó and Miquel Utrillo i Morlius further encouraged his love of Spanish art, and both artists contributed to the design of his Sitges estate. The Palacio Maricel is now a museum, with some of Deering's collection on display as well as a portrait of Deering done by Casas. ${ }^{14}$ The rapid growth of Miami put pressure on the idyllic setting of Buena Vista, and so Deering selected a second site further south in what constituted the majority of the frontier town of Cutler, purchasing the Richmond Cottage and surrounding buildings. Phineas Paist, major artistic

\footnotetext{
${ }^{12}$ Margot Ammidown, "Walter DeGarmo: Fantasies in Concrete," Update, Vol. 11, No. 1 (Feb. 1984): 3-6.

${ }^{13}$ Mentioned in David Fairchild, The World Grows Round My Door (New York: Charles Scribners' Sons, 1947), 57.

${ }^{14}$ Isabell Coll Mirabent, Charles Deering and Ramón Casas: A Friendship in Art (Evanston, IL: Northwestern University Press, 2012).
} 
contributor for Coral Gables, designed a Spanish villa of limestone for Deering at the Cutler location in 1922 to supplement the wood cottage building. ${ }^{15}$

August Geiger, an architect and designer from New Haven, Connecticut, arrived in Miami in 1905 and established his own architectural firm by 1911. His designs received national attention for their employment of concrete as a building material, and his design for William Jennings Bryan's winter home, Villa Serena, was among the first to employ a specifically Spanish Colonial Revival style. Bryan's wife, Mary Baird Bryan, actively participated in the design with Geiger (Fg. 3.1). Mary traveled to Cuba for inspiration, and she acquired mosaic tiles and barrel roof tiles directly from Cuban factories for the construction. ${ }^{16}$ Located south of the Miami River on bay front land purchased from Mary Brickell, Villa Serena was one of several notable estates on Brickell Avenue in what became known as Millionaire's Row, later joined by Geiger's design for Carl G. Fisher's estate, complete with a Spanish bell tower from where Fisher could view his Miami Beach development across Biscayne Bay, the estate of Louis Comfort Tiffany, and Charles Deering's half-brother James's Villa Vizcaya. The use of Cuban building materials for Villa Serena also anticipated historian Louis Pérez's argument concerning the 1920s connection between Havana and Miami: "An odd symbiotic imperative linked Havana and Miami in an inexorable relationship:

\footnotetext{
${ }^{15}$ Emily Dietrich, Elise Brault-Hoessly, Robert Carr, and Michael Zimny, "The Charles Deering Estate," Nomination Form for National Registry of Historic Places, Jan. 1986.

16 "Bryan Home Nearly Completed," Miami Daily Metropolis, Apr. 11, 1913; "Villa Serena," Historic Preservation Report of City of Miami, Dec. 4, 2007.
} 
Havana aspired to modernity; Miami invented itself in antiquity." ${ }^{, 17}$

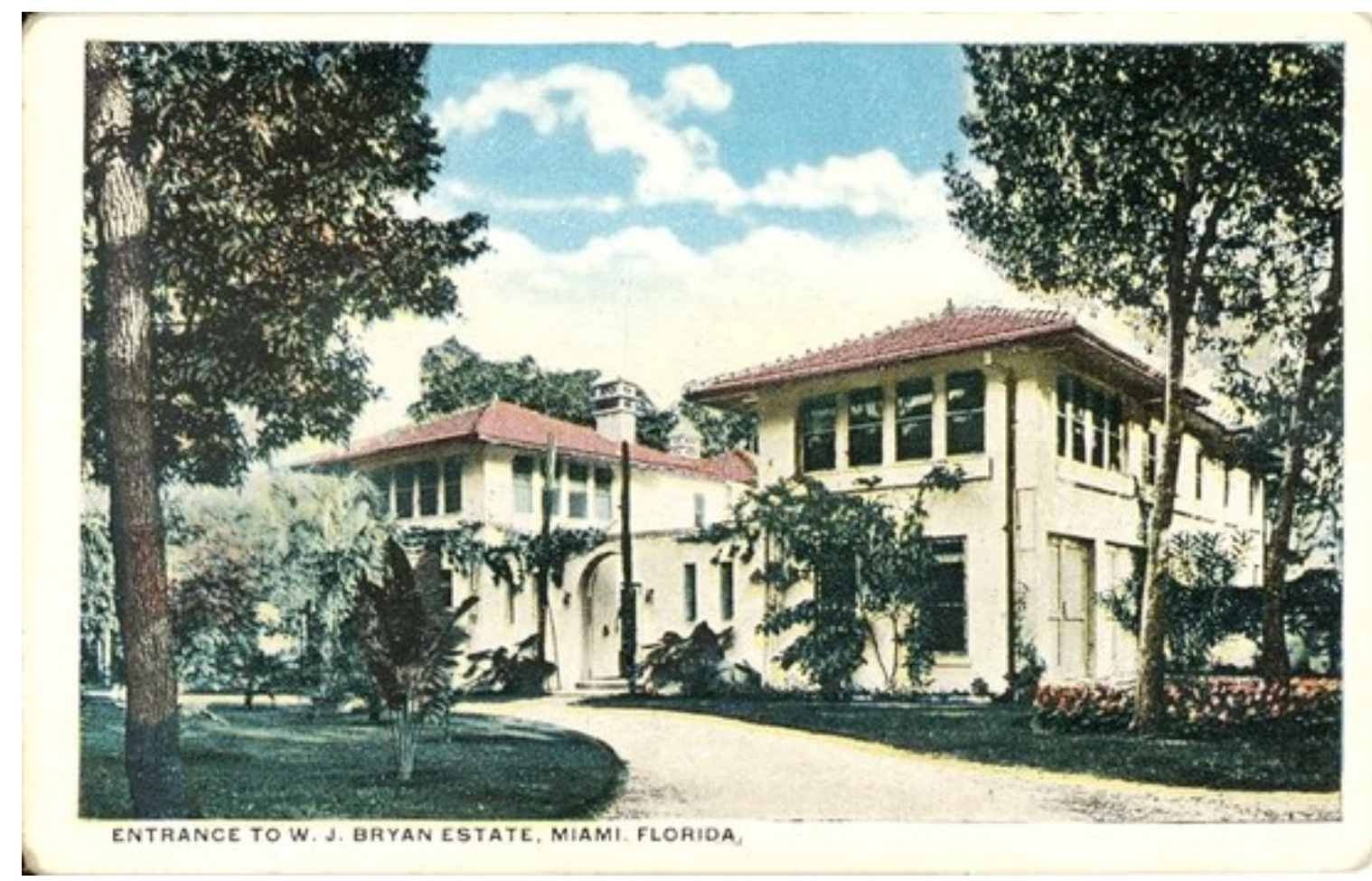

3.1 "Entrance to W.J. Bryan Estate, Miami, Florida," 1930s. Public Domain.

Geiger did not limit his designs to palatial estates. The growing city's

demands for expanded municipal services resulted in Geiger's approved design in

1916 for a new hospital building, referred to as The Alamo, now part of Jackson

Memorial Hospital's campus. The Alamo replaced an overburdened facility built

in 1909. Among the design features that signaled a Spanish inspiration were

ornate, low relief carvings on the exterior facades, an arcaded veranda, octagonal

copula, parapet gabled roofs and wall dormers, and an elaborate entrance

${ }^{17}$ Louis A. Pérez Jr., "Between Encounter and Experience: Florida in the Cuban Imagination," Florida Historical Quarterly, Vol. 82, No. 2 (Fall 2003): 178; the modern U.S. architectural influence in Cuba contemporary to Miami's invented antiquity is best covered in José A Gelabert-Navia, "American Architects in Cuba: 1900-1930," Journal of Decorative and Propaganda Arts, Vol. 22, Cuba Theme Issue (1996): 132-149. 
corridor. ${ }^{18}$ Geiger's growing practice provided opportunities for other aspiring architects, including Martin Luther Hampton, with whom Geiger designed The Alamo as well as a Caribbean inspired open-air market in Palm Beach called the Beaux-Arts Shopping Center (1916) before Hampton opened his own practice in $1917 .^{19}$

Geiger designed municipal, commercial, and residential buildings outside Miami in Palm Beach, Broward, and Dade Counties, including the Fort Lauderdale Women's Club, the Homestead School, and a bungalow for Professor R. E. Hall, superintendent of Dade County public instruction. Featured in a series of articles for a national building trade journal, The Concrete Age, the periodical credited Geiger, "with much of the concrete construction," in the Miami area, which, "continues to hold its rank in the forefront of American municipalities in the consumption of cement and therefore in permanent construction. ${ }^{, 20}$ Another article displayed floor plans for the Homestead School and the Hall bungalow along with images of the structures, "just to show the general run of his [Geiger's] work, not the most ornate or most expensive but typical solutions of the problem of designing a concrete home of moderate cost in a city full of such structures."21

18 "The Alamo," Historical Preservation Report of City of Miami, Sep. 15, 1982; see also, Margo Harakas, "Remember the Alamo," Sun-Sentinel, Apr. 14, 1997.

${ }^{19}$ Joan Mickelson, "Pioneer Architect Leaves Mark on City," Broward Legacy, Vol. 26, No. 1 (2006): 17-25.

20 "Concrete Homes at Ocean Beach, FLA," The Concrete Age, Jan. 1915, 12.

${ }^{21}$ George R. King, “A Miami Architect's Work in Concrete," The Concrete Age, Feb. 1915, 11-12. 
Less reliant on cost-effectiveness were estates Geiger designed for Carl Fisher and Hanan Shoe Company president John Hanan, featured in a 1917 issue of the San Francisco-based The Architect and Engineer of California. Hanan's estate offered a more familiar Colonial Revival style from Geiger, with white columns and unadorned facades and flat, open roofs, while Fisher's estate contained elements of Spanish Revival with barrel tiles and extensive use of arched windows with protective awnings (Fg. 3.2 and 3.3). ${ }^{22}$ Geiger's favorable coverage in national print media highlighted the significance of his work among his contemporaries like Walter DeGarmo (1905), Clinton McKenzie (1911), Edward A. Nolan (1912), Martin Luther Hampton (1915), F. Burrall Hoffman (1916), Richard Kiehnel (1917), Miami’s first female architect Marion Manley (1917), and Addison Mizner (1918), among others.

22 "Some Attractive Homes of Well Known People," The Architect and Engineer of California, Vol. 50, No. 1 (1917): 63-64. 


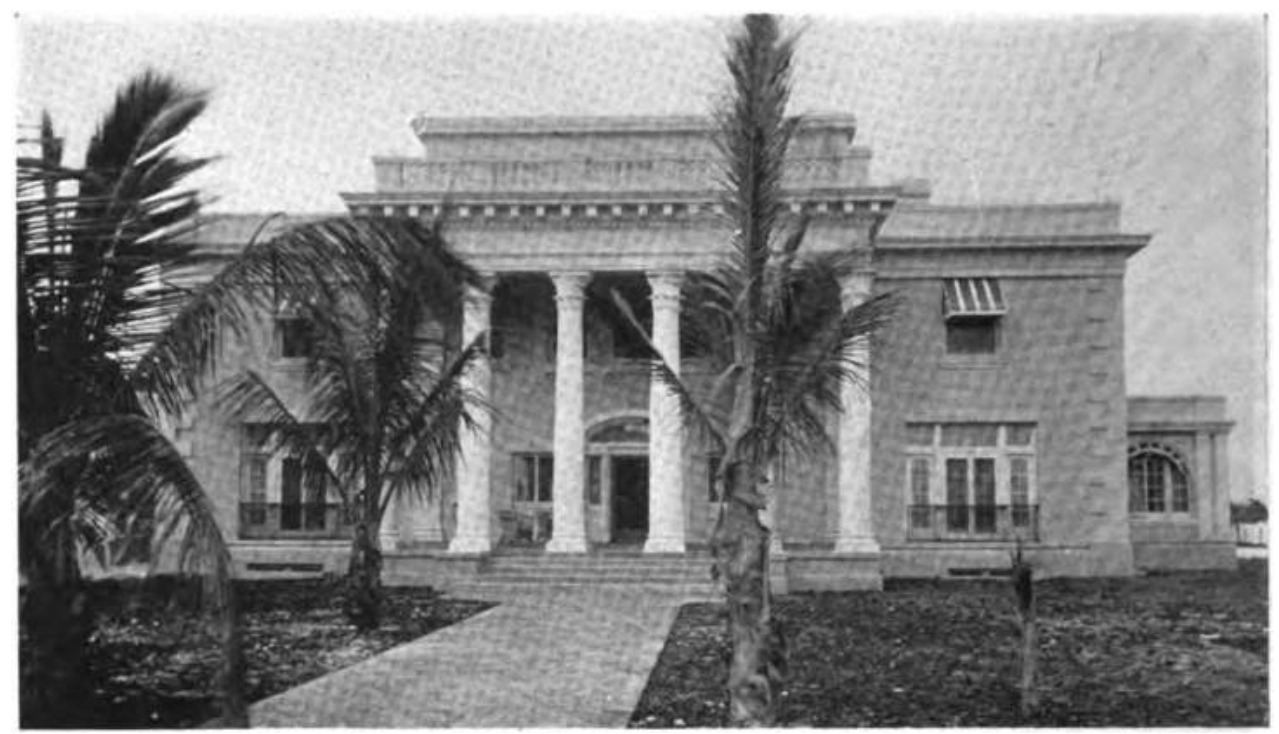

WTNTER HOME, MR, JOHW H. HANAN, MLAMI, FL.A.

Atgust Geiger, Arrhitect

Figure 3.2 "Winter Home, Mr. John H. Hanan, Miami, Florida, August Geiger,

Architect." The Architect and Engineer of California, Vol. 50, No. 1, (1917.) Public Domain.

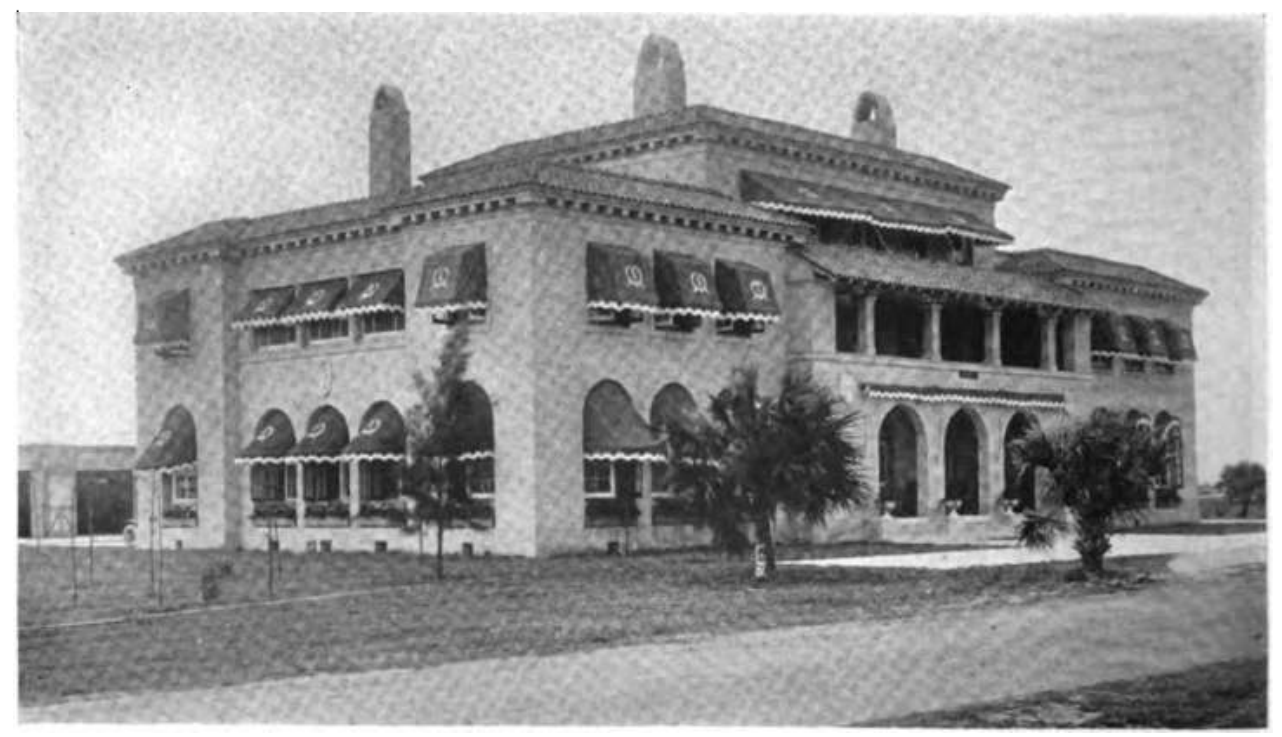

HOLSE OF MR, CARL G. FISHER, MIAM, FL.A.

Angust Griger, Architest

Figure 3.3 "House of Mr. Carl G. Fisher, Miami, FLA. August Geiger, Architect." The Architect and Engineer of California, Vol. 50, No. 1 (1917). Public Domain.

As much as August Geiger accomplished in the 1910s to position Miami on the national architectural map, two private estates by other architects have received the lion's share of credit for the Spanish and Mediterranean styles that 
flourished in the 1920s Miami suburbs. The most widely regarded, F. Burrall Hoffman's Villa Vizcaya for James Deering, drew inspiration and materials from Deering's trips to France, Spain, and Italy in the early 1910s along with his art adviser, Paul Chalfin. They sent back huge caches of buildings materials, stored in New York City warehouses prior to their final destination in Miami, and Hoffman's architectural designs were based on his encounter with the warehoused materials. Deering and Chalfin met a young Colombian landscape architect, Diego Suárez, in Venice during one of the trips, and were impressed enough to commission Suarez as lead designer of the grounds. ${ }^{23}$ In a forty-six page illustrated tour of the residence and grounds for a July 1917 issue of The Architectural Review, Paul Chalfin took Hoffman's and Suárez's absence as the opportunity to take undo credit for the design, listing himself as associate architect for the residence along with Hoffman, and listing himself as the sole designer of the grounds without mention of Suarez at all. ${ }^{24}$ Hoffman and Suarez eventually received vindication only after demanding a retraction to a 1953 New York Times retrospective that again privileged Chalfin as the main designer. ${ }^{25}$ Although inspired by Europe, Vizcaya contained sandstone and other building materials from Cuba, following the Villa Serena pattern of

\footnotetext{
${ }^{23}$ Donald W. Curl, "The Florida Architecture of F. Burrall Hoffman Jr., 18821980," Florida Historical Quarterly, Vol. 76, No. 4 (Spr., 1998): 399-416.

24 “'Vizcaya,' the Villa and Grounds: A House at Miami, Florida," The Architectural Review, Vol. 5, No. 7 (Jul., 1917): 121-167. Curl mistakenly cites this article as dating from April in his footnote 12.

${ }^{25}$ Curl, 404-406.
} 
appropriated Spanish Colonial materials imported for Miami development from throughout the Americas. ${ }^{26}$

Architectural historians often privilege Pittsburgh architect Richard Kiehnel's 1917 design of El Jardin in Coconut Grove for Pittsburgh Steel Company president John Bindley as the origin of Mediterranean Revival. Architectural critic Beth Dunlop goes so far as to credit El Jardin as, "the first building to explore the picturesque and romantic possibilities of a mixedmetaphor architecture of Mediterranean inspiration and the first in Florida to consciously employ creative crafting and coloration to make the new look old.",27 Yet, as this section makes clear, Spanish design elements factored into several buildings by Geiger and others in Miami before 1917, with origins of such design inspirations traceable to Saint Augustine, Henry Flagler, and Julia Tuttle, thus El Jardin should be understood as the culmination rather than the origination of an artistic and cultural impulse.

Perhaps the source of the confusion can be traced to Miami architect Russell T. Pancoast, who wrote in 1963 that Kiehnel came to Miami, "recognized the Mediterranean trend, accepted it eagerly and gave it impetus." 28

${ }^{26}$ Louis A. Pérez Jr., On Becoming Cuban: Identity, Nationality and Culture (Chapel Hill, NC: University of North Carolina Press, 1999), 433.

${ }^{27}$ Beth Dunlop, "Inventing Antiquity: The Art and Craft of Mediterranean Revival Architecture," Journal of Decorative and Propaganda Arts, Vol. 23, Florida Theme Issue (1998): 196.

${ }^{28}$ Russell T. Pancoast, "Miami Architecture So Far," in A Guide to the Architecture of Miami (Miami: Florida South Chapter, American Institute of Architects, 1963), 12. 
Unfortunately, Geiger is absent from Dunlop's list of architects that supposedly followed Kiehnel's lead, despite the fact that Kiehnel recognized and accepted an already-existent trend, and many histories of Miami architecture generally overlook him. ${ }^{29}$ Some notable features of El Jardin, though, included the use of chemical solutions on the exterior that encouraged mildew growth as an intended technique of instant aging, as well as deep-set frieze decorations throughout the exterior facades and along window and door treatments, and artificial veining and pores created in the limestone casts. ${ }^{30}$

The Plymouth Congregational Church, across Coconut Grove's Main Highway from El Jardin, begun in 1916 and completed in August of 1917, drew inspiration from colonial Mexico and the Catholic mission style churches (Fg. 3.4). New York architect Clinton McKenzie designed the church, likely as a result of his work for Charles Deering at Buena Vista, and McKenzie commissioned a stonemason from Spain, Felix Robom, as the builder. Robom laid the entirety of

${ }^{29}$ Dunlop, "Invented Antiquity," 198. Listed architects include Martin Luther Hampton, Phineas Paist, and Walter DeGarmo. The exception to the rule is found in Nicholas N. Patricios, Building Marvelous Miami (Gainesville, FL: University Press of Florida, 1994), 94, who correctly positions Geiger as the lead architect of the Spanish Revival style, even though he begins with The Alamo and not Villa Serena. Geiger is absent from the comprehensive A Guide to the Architecture of Miami (Miami: Florida South Chapter, American Institute of Architects, 1963). Geiger is only listed in the caption of two photos in Hap Hatton's otherwise excellent Tropical Splendor: An Architectural History of Florida (New York: Alfred A. Knopf, 1987), 58-59; Geiger is not mentioned in Jose M. Lozano, "The Last Eclectics: Walter DeGarmo and Richard Kiehnel in South Florida," Southeastern College Art Conference Review (1990): 363-371.

${ }^{30}$ Russell T. Pancoast, "Miami Architecture So Far," in A Guide to the Architecture of Miami (Miami: Florida South Chapter, American Institute of Architects, 1963), 13; "El Jardin," Historical Preservation Report of City of Miami, Dec. 14, 1982. 
the exterior stone by hand supposedly all by himself. The 375 -year-old oak and walnut front door was acquired from a monastery in the Pyrenees, complete with its original wrought iron fittings. Pastor George Spaulding and the church's board chairman George Merrick, whose father Solomon pastored the congregation in 1901, raised funds and encouraged the new house of worship's construction. ${ }^{31}$ The monumental design and material of Plymouth and other churches in Miami reflected the means and power of a local white male Protestant establishment, fully formed by the 1910s, whose spirit of capitalist competition expanded outward from churches and estates to entire planned communities by $1920 .^{32}$

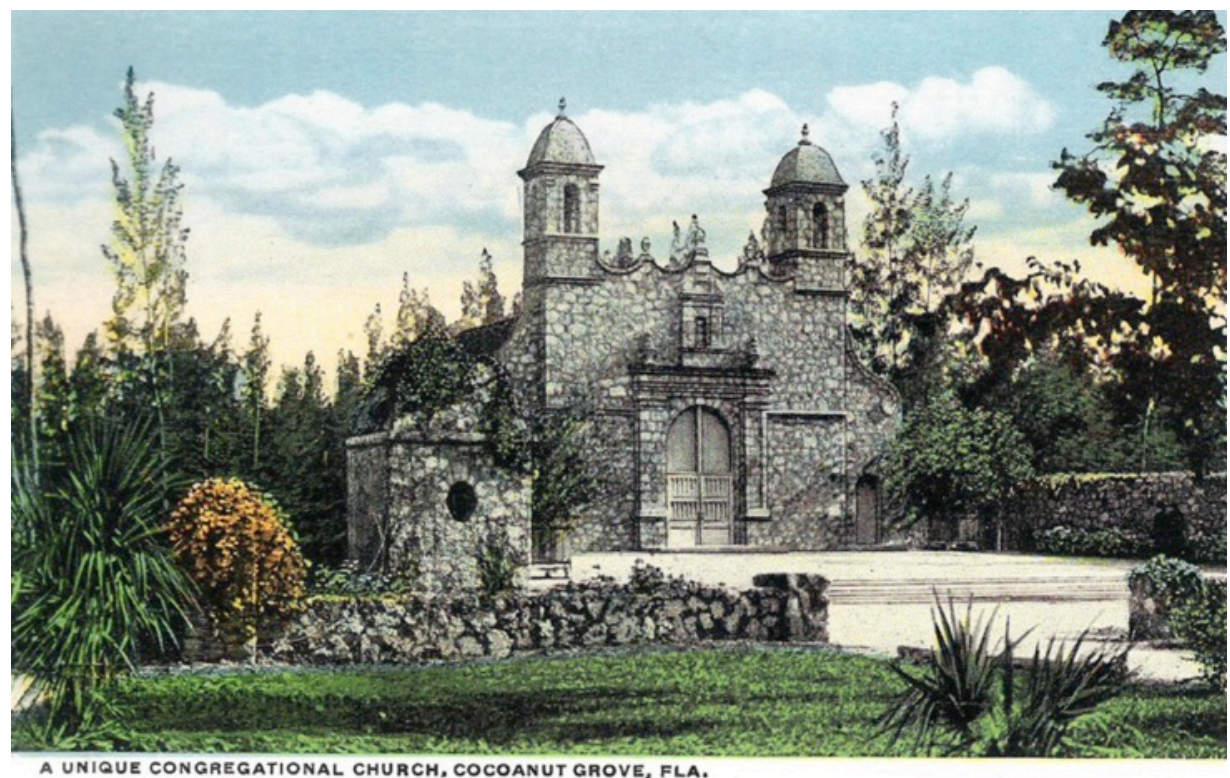

3.4 "A Unique Congregational Church, Cocoanut Grove, FLA," Postcard, 1930s. Public Domain.

31 "Plymouth Congregational Church," Historical Preservation Report of City of Miami, Nov. 19, 1982.

${ }^{32}$ How Miami so rapidly coalesced as such is recovered in Thomas A. Tweed, "An Emerging Protestant Establishment: Religious Affiliation and Public Power on the Urban Frontier in Miami, 1896-1904," Church History, Vol. 64, No. 3 (Sep., 1995): 412-437. 


\section{Subdivided and Conquered: Spanish Architecture and Speculative Development}

With an established Spanish architectural trend sourced from local limestone, the stage was set for an unprecedented real estate market expansion in Miami by 1920. Promoters of new developments used the winter estates of major capitalists built throughout the 1910s as the shining examples upon which to build their planned suburban developments. South Florida land also possessed a certain mystical, magic quality, according to Theyre Weigall, an impoverished English journalist who arrived to Miami from New York in 1925 and became a ghostwriter for George Merrick. "Nobody knew what Florida land was actually worth," he wrote of his time in Miami, "apart from the boom conditions; nobody knows even to this day." 33 Promoters deftly avoided the clear risk of investment in land of unknown value and instead they touted the rapid population growth of the city, the capital deposits in the city's leading banks, the tropical climate, and the permanent quality of the concrete construction techniques employed in residential and commercial structures. From 1900 to 1920, the population of Miami grew from 1,681 to 29,571 and that of Dade County grew from 4955 to over 42,753, and bank deposits in the six leading banks totaled over $\$ 20,000,000 .^{34}$ Those numbers seemed paltry by 1925 , however, when cleared deposits soared over $\$ 1,000,000,000$ and the population approached $100,000 .^{35}$

\footnotetext{
${ }^{33}$ Theyre Weigall, Boom in Florida (London: Bodly Head Limited, 1931$), 7$.

${ }^{34}$ The Eighteenth Decennial Census of the United States, US Bureau of the Census, Vol. 1, Part 11, Florida (Washington, DC: US Government Printing Office, 1963), 11; "Florida Population of Counties by Decennial Census: 1900 to
} 
Carl Fisher, George Merrick, Glenn Curtiss, and Earl Royce Dumont, among other capitalists, pursued planned community development in and around Miami as means of further wealth accumulation in a growing city prior to the height of the boom in 1925. Fischer's Miami Beach, Merrick's Coral Gables, the overlapping efforts of Curtiss and Dumont in Miami Springs, Curtiss's Opa Locka and Hialeah, and Dumont's Coral Villa, all signaled a new era of planned suburban growth that older communities like Lemon City, Little River, Buena Vista, Allapattah, and Coconut Grove never intended or imagined for themselves. Influenced to varying degrees by the City Beautiful movement, with its origins in Daniel Burnham's plan for Chicago and the 1893 World's Columbian Exposition, the new suburbs further consolidated the class hegemony of these and other men of capital in Miami, as the beautified suburbs materially substantiated the personal greatness of their developers in the absence of government-led public planning and development. ${ }^{36}$ Only when such private efforts stalled or failed did new approaches of metropolitan governance commence.

1990," compiled and edited by Richard L. Forstall, (Washington, DC: US Bureau of the Census, 1995); Ethan V. Blackman, Miami and Dade County, Florida: Its Settlement, Progress, and Achievements (Washington, DC: Victor Rainbolt, 1921), 23-24; Isidor Cohen, Historical Sketches and Sidelights of Miami, Florida (Miami: Privately Printed, 1925), 125-135, 192; Elliott Mackle, “Two-Way Stretch: Some Dichotomies in the Advertising of Florida as the Boom Collapsed," Tequesta, Vol. 33 (1973): 17-29.

${ }^{35}$ Frank B. Sessa, "Miami in 1926," Tequesta, Vol. 16 (1956): 20; Miami population reached 110, 637 by 1930 and Dade County population reached 142,955 by 1930, "Florida Population of Counties by Decennial Census."

${ }^{36}$ The links between private capital and the emergence of City Beautiful reforms nation-wide is found in Richard E. Foglesong, Planning the Capitalist City: The 
A series of ten advertisements in the New York Times from May to June 1921 introduced New Yorkers to the Montray Corporation and its founder Earl Royce Dumont. Dumont gained a fortune from a publishing company that printed great works of predominantly French masters, including the first English edition of Voltaire's complete works in forty-two volumes. His real estate developments began at Westbury, Long Island, including the Wheatly Villa section of that suburb, and then his company acquired developments in Hempstead, New York, the Mid Lake Park section of Lakewood, New Jersey, and had started a Montray Heights development in Glenn Falls, New York at the time of his arrival to Miami in the winter of 1918, a destination chosen because he had been working so hard and needed to recover in what he called the "Magic City Beautiful." Reinvigorated and impressed by the bustling business scene in Miami, Dumont decided to purchase land from a New York friend he happened to run into on the streets that winter. Although his wife objected to working during their vacation, Dumont insisted it was not much work and he was getting a lot of fun out of subdividing and laying out plots on his purchased property. The "snug little profit" made off this initial subdivision was rendered incidental to Dumont's enjoyment in developing the lots. The faux-news story style ad concluded with a description of an aerial photograph of Miami on display at Dumont's New York office in the Astor Trust Building on the corner of Fifth Avenue and Forty-Second Street in midtown Manhattan, with a form for interested investors to fill out to make an appointment to see the photograph and learn more about Montray's

Colonial Era to the 1920s (Princeton, NJ: Princeton University Press, 1986), 124125. 
Miami properties. ${ }^{37}$ The tagline for this and the subsequent ads read: "MIAMI and MONTRAY: Names that are united to bring happiness and prosperity to many people. 38

Dumont's selling point for lots in Miami’s fringes consistently highlighted the growth of the city and the inevitably of the city reaching his subdivisions, increasing the value of properties for investors. A promotional brochure from October 1921 summarized the arguments in the New York Times ads, with vibrant colored illustrations of Miami, the Montray properties, as well as people enjoying outdoor activities like boating and golf, and a reproduction of the aerial photograph of Miami displayed in Montray's New York office. The cover dramatically illustrated Dumont's vision, with a feminized symbol of Miami as an Art Nouveau model named Helen Moorehead rising above the city to make plain its future growth (Fg. 3.5). In a section highlighting schools and churches in Miami, the brochure stressed the moral foundation of Miami's developers: “Progress has ever been and will be Miami's watchword. Honor in all transactions is the key that has unlocked the door of opportunity and kept within Miami's area a class of people that themselves are progressive and operate on honor. Success

${ }^{37}$ Display Ad 76, The New York Times, May 26, 1921, 9.

${ }^{38}$ ibid., Display Ad 66, The New York Times, May 27, 1921, 12; Display Ad 78, The New York Times, May 31, 1921, 11; Display Ad 56, The New York Times, Jun. 6, 1921, 8; Display Ad 25; Jun. 13, 1921, 16; Display Ad 67, The New York Times, Jun. 20, 1921, 13; Display Ad 113, The New York Times, Jun. 27, 1921, 21; Display Ad 55, The New York Times, Jul. 5, 1921, 11; Display Ad 72, The New York Times, Jul. 10, 1921, 29; Display Ad 30; The New York Times, Jul. 25, $1921,6$. 
has followed, naturally." ${ }^{39}$ Honorable growth by a progressive class of church and school loving people in pursuit of clean entertainments for the whole family concealed the risk of site unseen investments by New Yorkers in Montray's office, freeing them of any lingering preoccupation about inflated prices or a real estate market bubble. The Montray ads early anticipated the criticisms of Miami's growth by 1925: "It is not a spurt; it is not a boom; it is continuous progress, which has been steady for 20 years, but more wonderfully steady and more marked during the past decade." 40

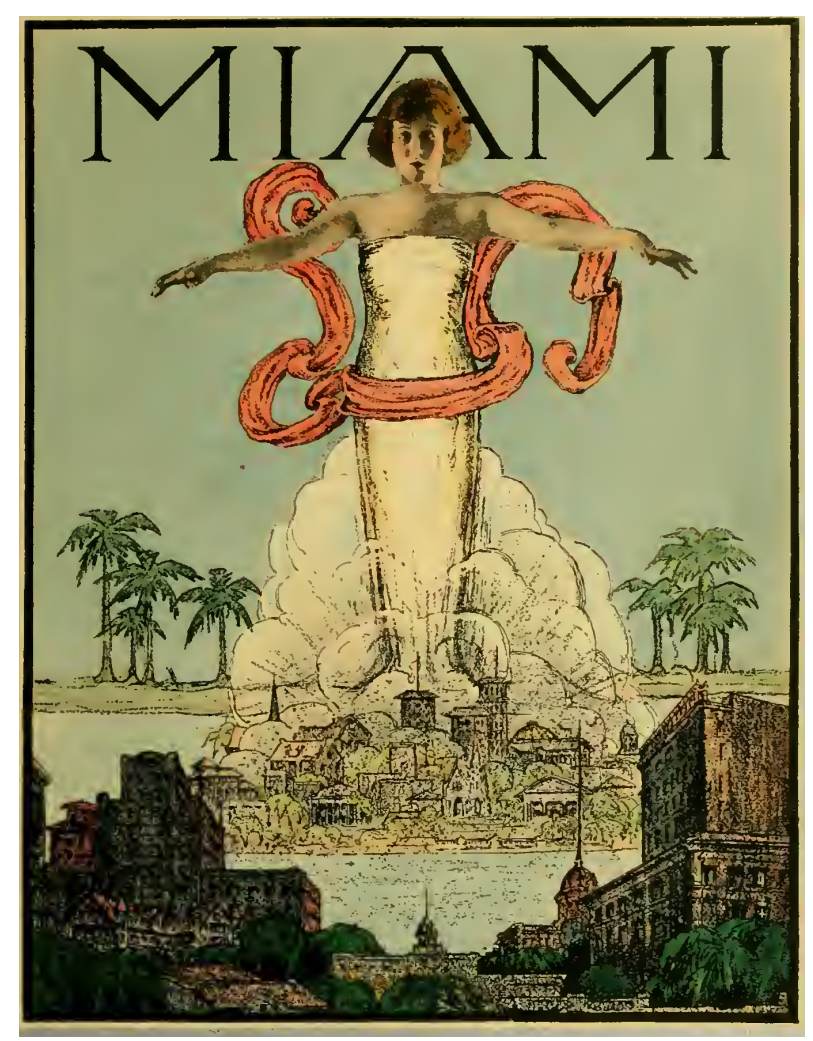

Figure 3.5 The caption under the cover illustration reads: "The spirit of Miami always rises above past achievements, lives in the present and plans for the future." Miami (New York: Montray Corporation, Oct. 1921). Public Domain.

${ }^{39}$ Miami (New York: Montray Corporation, Oct. 1921), 4.

${ }^{40}$ Display Ad 78, The New York Times, May 31, 1921, 11. 
Montray's New York promotional machinery joined Carl Fisher's lime-lit sign in Times Square, hung in the winter of 1920, that simply read, "It's June in Miami." ${ }^{41}$ Theyre Weigall described his encounter with the Miami ad blitz in New York as the push factor for his personal decision to move south. After hearing Will Rogers lament from a Broadway stage the fact that his domestic ties to New York prevented him from pursuing the Miami boom times, Weigall left the theater only to see window ads on the corner of Fifth and Forty-Second, no doubt from Montray, which proclaimed that, "One Good Investment Beats a Lifetime of Toil," accompanied by an anecdote of an investor who made $\$ 500,000$ in Miami in four weeks simply by judging correctly and investing in rising land values. ${ }^{42}$

The promise of making money in Miami real estate received a further inducement from the November 1924 Florida state elections, which amended the state constitution to abolish income and inheritance taxes. ${ }^{43}$ Accumulated wealth of one generation could then enrich subsequent generations to an unprecedented extent. Building permits in Miami reflected the optimistic investment climate. In 1923 , permits totaled $\$ 5,723,695$ for the four-month period from April to July. By

${ }^{41}$ Hap Hatton, Tropical Splendor: An Architectural History of Florida (New York: Alfred A. Knopf, 1987), 58.

${ }^{42}$ Weigall, Boom in Florida, 14-15.

${ }^{43}$ Ballinger, Miami Millions, 24. 
August 1924, permits reached $\$ 4,000,000$ for that month alone. The peak building permit total came in October 1925 , with $\$ 15,787,539$ for that 31 -day period. ${ }^{44}$

Amidst the dramatic rise in building, public faces of the boom stressed the responsible and durable growth underway. In a front-page March 15, 1925 article in the New York Times titled, "Millions of Capital Drawn to Miami," George Merrick countered rumors of Miami's boomtown reputation and also took the time to advertise his master suburb, Coral Gables. Articles that compared Miami to a Klondike gold rush or a Texas oil boom were, "simply silly, sob-sister, sensational writing." To back up his argument, Merrick, like so many of his contemporary developers and promoters, pointed to numbers: "In Coral Gables there has been expended during the past three years over $\$ 21,000,000$ in hard, cold cash. There has been nearly $\$ 30,000,000$ of realty sales made throughout thirty-eight of these United States." ${ }^{45}$ Not only was investment durable in "hard, cold cash," but also it came from investors throughout the country, lending, in Merrick's judgment, an air of credibility against accusations that it was merely a local promotional phenomenon.

Merrick's ability to attract cash to Coral Gables was mostly due to the sheer completeness of his vision for a master suburb, which began with the choice of an appropriate, appropriated style: "Just how I came to utilize the Spanish type of architecture in Coral Gables, I can hardly say, except that it always seemed to

\footnotetext{
${ }^{44}$ Ibid., 5.

45 "Millions of Capital Drawn to Miami," The New York Times, Mar. 15, 1925, 12.
} 
me to be the only way houses should be built down there in those tropical surroundings." He clarified as to why exactly it made so much sense for south Florida: "I made a trip to Mexico and Central America and was more convinced than ever of the possibilities offered by the adaptations of the Spanish and Moorish type of architecture. The gleaming white coral rock, the palm trees, tropical flowers and verdure seemed to me to provide a natural setting with which Spanish architecture alone would harmonize." ${ }^{46}$ No more natural than the introduced tropical verdure, Merrick's belief in the correctness of Spanish architecture farcically repurposed the tragedy of Spanish colonial conquest as the means of creating a master suburb. Through an appropriated Spanish style, Merrick attempted to legitimize his capitalist vision.

Merrick's Spanish architectural aesthetic received glowing praise from the former editor of House Beautiful magazine, Virginia Robie, in her introductory remarks to the promotional brochure The Story of Coral Gables (1926): "It is fitting that the Spanish style should have been the chosen one for Coral Gables. No other would so consistently blend with the country, climate and background. No other would so perfectly express the history and atmosphere of this part of the new world which Spain more than four hundred years ago made her own." ${ }^{\text {"47 }}$ The new master suburb perfectly expressed the history and atmosphere that Miami's elite constructed as the antecedent to their own capitalist enterprise. The romance

${ }^{46}$ Ibid., 2.

${ }^{47}$ Virginia Robie, "Forward," The Story of Coral Gables (Miami: Parker Art Printing, 1926), 3-4. 
of Spain's imperial rule in the Americas "four hundred years ago" helped Robie, Merrick, and others make sense of a truly modern suburban landscape.

Merrick's maternal uncle, Denman Fink, added the artistic credentials to Merrick's realized ideal. Fink, a member of the U.S. Government's Committee of Twenty-one American Artists, studied Spanish art and architecture for many years prior to his commissions for his nephew. His article in the same promotional brochure, poetically titled, “"Castles in Spain’ Made Real,” further elaborated the design imperative of Spanish architecture for Coral Gables. New England style houses and Swiss chalets in Miami struck Fink as comparable to a polar bear in a southern zoo; they simply felt out of place. While other builders in Miami attempted to simulate age-toned walls of old foreign cities, "Few and far between are the places which when completed do not cry aloud of their newness." The purely Spanish treatment in Coral Gables, in contrast, would not give any sense of "blatant newness, even from the start, for in very truth it will not be new. It will simply be ages-old material taking on new forms. ${ }^{, 48}$ Spain's imperial conquest of the Americas, the primary sources of the ages-old material, took on the new form of private, capitalist real estate development. Fink clearly articulated the vision for Miami as a realization of imperialism centuries in the making. Modern U.S. capital and colonial Spanish materials combined to create Miami as an imperial city.

Large quantities of age-old building materials, indeed, came into Coral Gables from crumbling edifices in Spain and its former colonial possessions,

${ }^{48}$ Denman Fink, “'Castles in Spain' Made Real,” The Story of Coral Gables (Miami: Parker Art Printing, 1926), 13-15. 
including over 100,000 pieces of Spanish tile sourced from Spain and Morocco. ${ }^{49}$ Samuel Crowther, the apologist for U.S. imperialism in Latin America encountered in chapter two, casually reported from Trujillo, Honduras that, "the whole town lost its red roof tiles to a spectacular intent on giving an old Spanish touch to the Florida boom.. ${ }^{50}$ In 1925, the demand for authentic Spanish materials prompted three Cuban artisans, José Escarra, Enrique Valdés, and Pedro Meliá, to open a factory in Coral Gables to produce decorative mosaic tiles for floor, wall, and ceiling treatments, as well as the signature red barrel roof tiles. ${ }^{51}$ Marjory Stoneman Douglas highlighted their significance for helping Denman Fink in building the prominent Douglas (Fg. 3.6) and Grenada entrances to Coral Gables: "Spanish masons were brought in from Cuba, men who were familiar with the idea that everything connected with every day living of people should be beautiful and worthy. ${ }^{, 52}$ Merrick's reputation as a master developer in the Spanish style led many interested parties from outside Miami to seek advice and to solicit design plans. Hamilton Holt, for example, the president of Rollins College in Winter

${ }^{49}$ Ballinger, Miami Millions, 22.

${ }^{50}$ Samuel Crowther, The Romance and Rise of the American Tropics (New York: Doubleday, 1929), 25.

${ }^{51}$ Pérez Jr., On Becoming Cuban, 433.

${ }^{52}$ Marjory Stoneman Douglas, Coral Gables: America's Finest Suburb, Miami, Florida (Miami: Parker Arts Printing, 1926), 20. 
Park, Florida, wrote Merrick to profusely thank him for arranging architectural plans for the college in the Spanish style. ${ }^{53}$

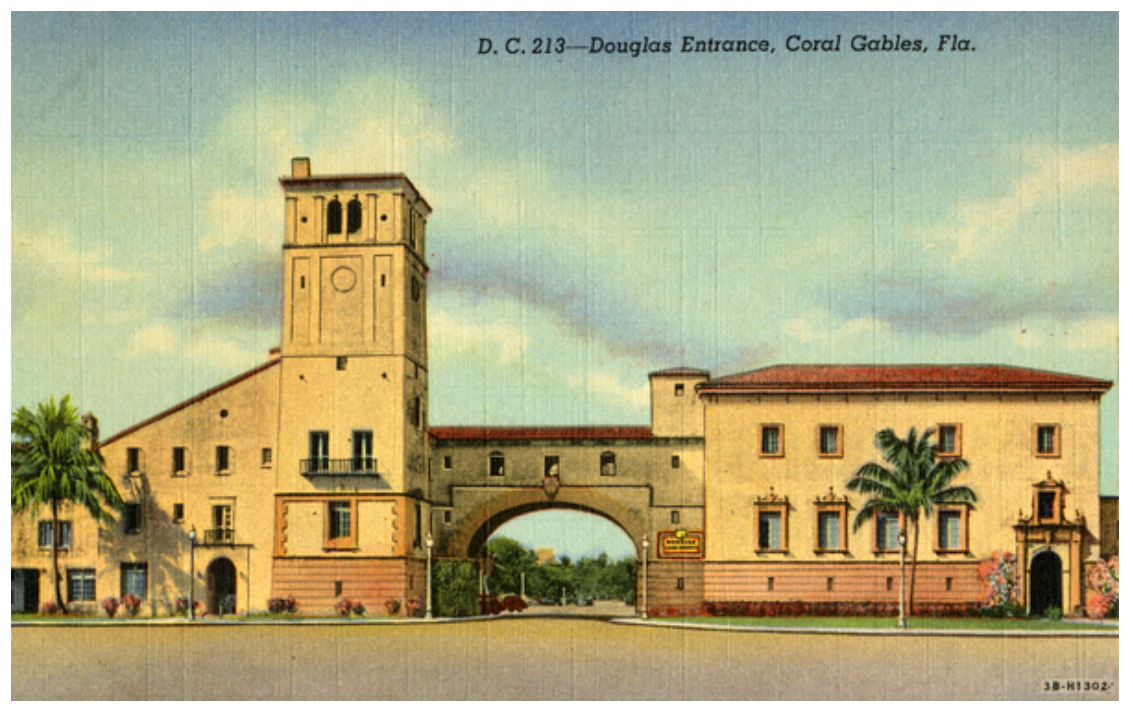

Figure 3.6 "Douglas Entrance, Coral Gables, Florida," Dade County Newsdealers Supply, Co., 1943, State Archives of Florida, Florida Memory.

Other meticulously designed suburbs in south Florida that followed versions of a Spanish style included Addison Mizner's extravagant but unfinished Boca Raton in Palm Beach County as well as aviator Glenn Curtiss's northwest Miami suburbs of Hialeah, Opa Locka, and Country Club Estates, whose name changed to Miami Springs in 1930 to reflect newly discovered fresh water wells that supplied Miami's municipal water. Curtiss contributed substantially to Miami's and the nation's aviation history, discussed in chapter four, but his partnership with a local cattle rancher named James Bright, who owned over 14,000 acres of reclaimed Everglades land in northwest Dade County, provided the land to live out fantasies of Spanish and Moorish design. Lots for Hialeah went on sale in 1921, and the architectural choice of Spanish Mission Revival or

${ }^{53}$ Letter from Hamilton Holt to George Merrick, Mar. 2, 1927, Folder 1958-003, 1-4, George Merrick Papers, Box 1, Charlton W. Tebeau Research Library, HistoryMiami. 
Pueblo Revival (Fg. 3.7) distinguished the Curtiss-Bright development from Coral Gables and other less inspired subdivisions. In addition to the unique architecture, Hialeah contained some of Miamians' most beloved entertainment venues and spectacles, including Hialeah Club racetrack and the nation's first permanent jaialai fronton. Less desirable were the gamblers and bootleggers that set up shop in Hialeah, with "Hialeah rye" becoming south Florida's most ubiquitous Prohibition-era spirit. ${ }^{54}$ In addition to racing, gambling, and distilling, Curtiss encouraged the establishment of south Florida's motion picture industry in Hialeah, and the enterprise's modest success positioned Miami as the third major site of motion picture production behind Los Angeles and New York. ${ }^{55}$

${ }^{54}$ Hap Hatton, Tropical Splendor, 65-65; see also, Gregory W. Bush, "'Playground of the USA': Miami and the Promotion of Spectacle," Pacific Historical Review, Vol. 68, No. 2, Orange Empires Issue (May, 1999): 153-172.

${ }^{55}$ Richard Alan Nelson, "Palm Trees, Public Relations, and Promoters: Boosting Florida as a Motion Picture Empire, 1910-1930," Florida Historical Quarterly, Vol. 61, No. 4 (Apr., 1983): 383-403. 


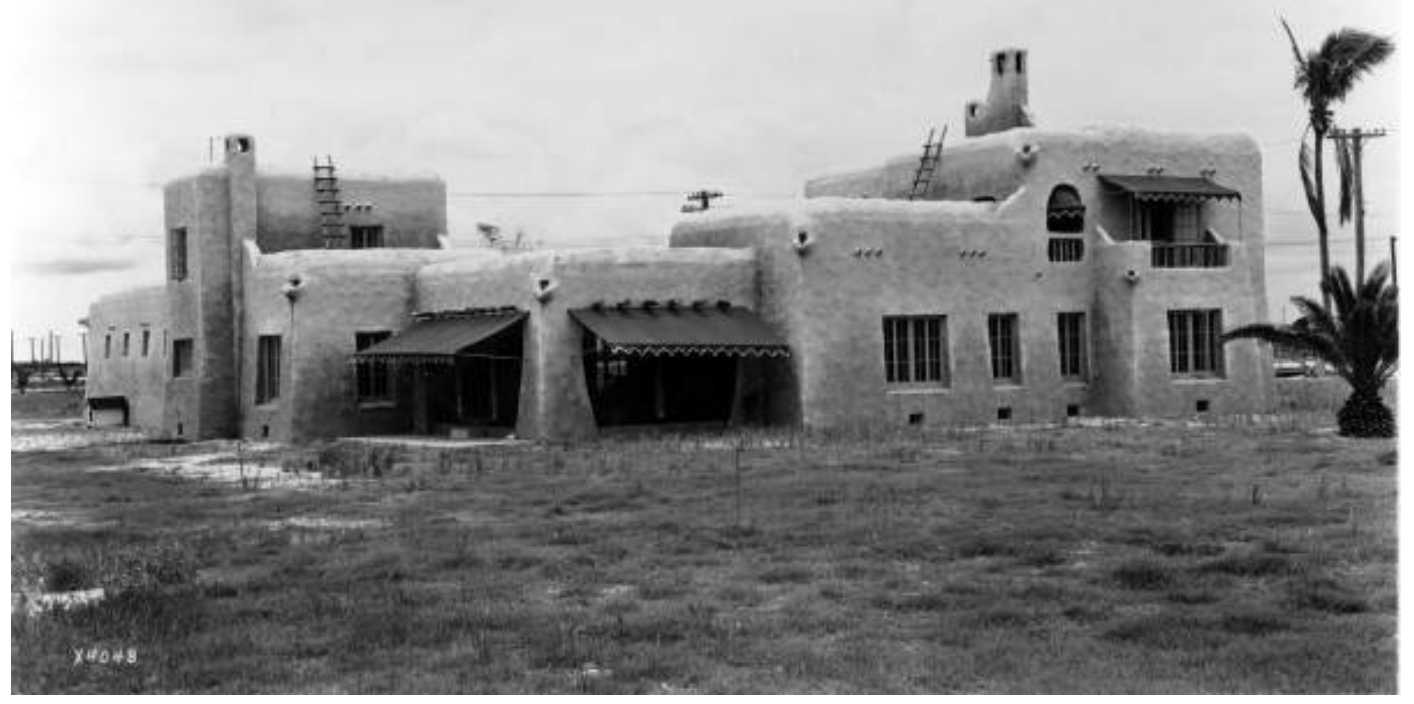

Figure 3.7 William A. Fishbaugh, "View of a House in Hialeah, Florida," June 8, 1926, State Archives of Florida, Florida Memory.

Disillusioned with the character of residents coming into Hialeah, Curtiss and Bright tried again with Country Club Estates, a development that started from the premise that no industries or big business would be allowed. Begun at the height of the boom in 1925, Country Club Estates continued the Spanish Mission style with faux-adobe walled houses of stucco and hollow structural tiles. Within twenty months, the new development had 135 homes, a golf course, and the structure of a proposed Pueblo Hotel (never opened to the public and later purchased for John Kellogg's Battle Creek-Miami Springs Sanitarium, covered in chapter two). Curtiss's many investments in Miami suburbs paid him handsomely, with eighteen separate corporations under his name that employed a sales force of 250 agents. $^{56}$

${ }^{56}$ Hatton, 65-67. 
The boomtimes for Curtiss, Merrick, Fisher, Dumont, and other lead developers in Miami peaked in 1925. Less scrupulous developers and real estate agents followed the major developers into the industry to the point that by July 1925, Miami had issued 5,917 real estate brokers' licenses and was putting new ones out at a rate of sixty per day. This class of speculators, colloquially known as "binder boys," increasingly overran Flagler Street in downtown, the site of many of the lead developers' real estate offices. The process started with a contract to buy a lot at ten percent down or less on the total value of the lot. The prospective buyer was issued a binder receipt to guarantee the sale, and a further ten or fifteen percent would be due from the buyer in thirty days to complete the first down payment and finalize transfer of ownership. In the increasingly frenzied real estate market, the demand for lots meant that the receipts themselves attained a form of currency as supplies were limited by the amount of lots available, so that profits could be made by buying binder receipts at a reasonable price and reselling them at a higher rate before the thirty-day window closed. "The movement spread like wildfire," wrote the boom's historian and first-hand observer, Kenneth Ballinger, "something similar to the margin speculating on the New York Stock Exchange, and for five months at least the binder boys set a pace that had the ordinary citizens glassy-eyed and breathless." ${ }^{, 57}$

It was not unusual to see the binder change hands eight times within thirty days, each at a further inflated price than the last. It was this wild speculative system that contributed to the Miami Herald becoming the largest newspaper in

${ }^{57}$ Ballinger, Miami Millions, 98. 
the country by July 1925, in terms of volume of real estate advertisements, with a daily run of 88 pages and over 160 pages for the Sunday edition. One woman remarked that, 'I'd like to take the Sunday Herald, but I'm afraid it would fall on me." ${ }^{58}$ The weight of the paper reflected the ballooning weight of the real estate market itself. The first signs of the boom's decline occurred when, in August 1925 , a highly valuable binder for a lot on Miami Beach began at $\$ 7,000$, exchanged hands multiple times and reached a height of $\$ 50,000$, but the last buyer never fulfilled the payment, and the binder reverted to a price of $\$ 25,000$, the first such instance of a binder not retaining its maximum value. ${ }^{59}$ Strategies designed to curtail the dangerous power of the binder boys further deflated land values. Valuable lots were sold to binder boys with unacknowledged lots attached that were then sold at a more reasonable price to devalue the initial receipt, leaving many of the "paper millionaires" out of luck. ${ }^{60}$ The speculative nature of the boom followed the promoted steady growth of lead developers. By promoting Miami as a safe investment, Merrick and others unintentionally provided the conditions for its collapse.

${ }^{58}$ Ibid., 5.

${ }^{59}$ Ballinger, 98-99.

${ }^{60}$ Ida Tarbell, "Florida - and Then What? Impressions of the Boom," McCall's Magazine, Vol. 53 (May, 1926): 6-7, 57, 89-92; also printed as "Impressions of the Florida Boom," St. Petersburg Times, Apr. 19, 1926, 4; see also, Paul S. George, "Brokers, Binders, and Builders: Greater Miami's Boom of the Mid1920s," Florida Historical Quarterly, 65 (July 1986): 27-51; for more on the boom in Palm Beach, see George B. Tindall, "The Bubble in the Sun," American Heritage (Aug. 1965): 78-83, 109-11; for more on the boom in Miami Beach, see Polly Redford, Billion-Dollar Sandbar: A Biography of Miami Beach (New York: Dutton, 1970). 
In August 1925, the same month as the first unfulfilled binder, the first in a series of events occurred that worked to end the inflationary bonanza for Miami suburban development. On August 17, a railway embargo was placed on Miami (excluding fuel, livestock, and perishables) by the Florida East Coast Railroad, as 820 loaded cars queued up in the railroad yard and another 1,300 cars stretching north to Lemon City waited in vain to be unloaded. The get-rich-quick scheme of the binder boys and the attendant suburban construction made railroad labor overly scarce. The embargo, thought to only last a short time, extended through the fall and winter of 1925, paralyzing the city. The slowdown accompanied a more immediate threat, a shortage of ice, resulting in an ice-rationing program of twenty-five pounds per family per month. ${ }^{61}$

In January 1926, the second major event to affect the boom transpired when the Prinz Valdemar, a 241' schooner intended as a 100-room floating hotel, sailed into Miami Harbor. On the ship's January 10 approach to the channel between Miami Beach and Fisher's Island, the ship capsized, blocking passage to and from Biscayne Bay and Miami's Harbor for over a month and preventing at least 100 ships with at least forty-five million board feet of lumber and other materials from unloading, adding further insult to the injury of the railroad embargo. The city commission planned and eventually completed a second channel around the half-submerged vessel. ${ }^{62}$

\footnotetext{
${ }^{61}$ Ballinger, Miami Millions, 119.

${ }^{62}$ Ballinger, 137-139.
} 
Ironically enough, the Prinz Valdemar was the only large ship to survive intact after the third and most infamous major disaster struck Miami in September 1926. When news of three powerful tropical storms in the Atlantic reached Miami on September 15, few took the warning seriously. The majority of the new population did not appreciate the danger, especially since the last hurricanes dated to 1910 and 1906. Reports of 100-miles per hour winds came on Friday, September 17, as the storm made its way from Turks Island northwest toward the Bahamas and south Florida. By 6 a.m. on Saturday morning, 125-mile per hour winds punished south Florida from Palm Beach to the Keys. A lull at 8 a.m., as the eye of the storm passed over Miami, sent people out into the fleeting calm to assess the damage, but soon enough the winds commenced again, and people spent all day Saturday fighting for their lives against the storm's record winds and tidal waves. ${ }^{63}$ A hand-printed, one-page edition of the Miami Daily News and Metropolis came out on Saturday night "as a duty to our readers." The paper featured only brief summaries of the damage as far as it could be assessed, as well as barometric readings that showed the low pressure surpassed the 1900 Galveston, Texas hurricane readings, and a brief editorial told its readers, "This is a time when personal loss must give way to the common good; when Miami must meet the situation as it should be met. This is a time for a high degree of courage,

${ }^{63}$ Ballinger, 153-154; Aretta L. Semes, "From Rising Sun to Daunting Storm: Miami in Boom and Bust, A Reminiscence," Tequesta, Vol. 58 (1998): 98-101. 
but Miami has it. This is a time for unity of action. It is a crisis to be met and disposed of.",64

Relief quickly followed the storm's cessation. The National Guard arrived and imposed martial law on Sunday and Monday, supported by the Red Cross in the provision of aid. Committees formed to provide food and shelter to the newly homeless, estimated at 47,000, and an impromptu children's bureau returned 250 children to their parents separated during the havoc. In Miami alone, 2,000 homes lay completely destroyed and 3,000 more sustained significant damage, mostly in sections where homes lacked the permanent construction of concrete so widely celebrated by the city's boosters. 118 souls lost their lives. The city suffered over $\$ 20,000,000$ in damages to commercial and residential properties, even after the deflation of property values. William Randolph Hearst's Chicago HeraldExaminer sent a train of 100 doctors, nurses, engineers as well as chlorine water treatment equipment, and Hearst personally donated the first $\$ 10,000$ received by the city's executive relief committee. President Gerardo Machado, a friend of the city and later resident, also sent a gunboat detail of doctors from Havana as a gift from the Cuban people. Coral Gables, due to the vast resources invested in its construction, suffered the least of any of the suburbs, while lesser developments lay in ruins. "The haste of boom construction," Kenneth Ballinger lamented, “exacted a frightful toll." ${ }^{, 65}$ Speculative capitalist motives directly contributed to

\footnotetext{
64 “Hurricane Hits Miami,” Miami Daily News and Metropolis, Sep. 18, 1926. ${ }^{65}$ Ballinger, Miami Millions, 155-157.
} 
the devastation. The supposedly responsible growth of the city proved tragically illusory.

Typical of Miami’s unflinching boosterism, Mayor E.C. Romfh, also chairman of the First National Bank of Miami, wrote to the national papers within a week of the hurricane to say that the recovery was almost complete. ${ }^{66}$ Playing down the damage of the hurricane became the modus operandi of the city's leaders, setting a dangerous precedent for future storms and future development, seen to a degree in the 1935 Labor Day hurricane and to the worst extent in 1992 with Hurricane Andrew. ${ }^{67}$

While critical of Mayor Romfh's deception, Kenneth Ballinger also remained optimistic from the viewpoint of 1936, with some justification, since the boom, "produced two results, an inflated set of land values and an enormous volume of construction. The first has dwindled or disappeared entirely. The second remains, and regardless of where the money and the equities involved have gone, the steel and wood and concrete are with us still." So enormous was the volume of construction that even in the noted recovery year of 1935, which saw building permits rise to the level of 1923, no more than thirty-two new subdivisions were created, compared to 395 in 1925, because "so much of Dade

${ }^{66}$ Ibid., 156.

${ }^{67}$ Theodore Steinberg, "Do-It-Yourself Deathscape: The Unnatural History of Natural Disaster in South Florida," Environmental History, Vol. 2, No. 4 (Oct., 1997): 414-438. 
county already is subdivided that they may soon have to begin cutting up 50-foot lots." 68

The Spanish architectural style of Merrick, Curtiss, and others masked the inherent risk of speculative suburbanization. Short-term profits and the nationwide investment in Miami real estate further delayed real assessments of any potential consequences for the people living and working during the boom. As discussed in the following section, even the dramatic decline of the bust did not impart definite lessons for leaders of Miami's development. Failure to provide municipal services and the inadequacy or unwillingness of local government leadership to prevent future real estate speculation led to dramatic changes of governance only in the 1950s.

\section{From a City and its Suburbs to a Suburban Metropolis: Civic Irresponsibility, Annexation, and the Origin of Metropolitan Governance}

Subdivided new lands west, south, and north outside Miami’s city limits showed the competitive capitalist nature of development during the boom. New suburbs sought to distinguish themselves from rivals to attract investors. The great urban scholar Lewis Mumford summarized the early-twentieth century movement to the suburbs throughout many cities in the West as an, "effort to find a private solution for the depression and disorder of the befouled metropolis: an effusion of

${ }^{68}$ Ballinger, Miami Millions, 160. 
romantic taste but an evasion of civic responsibility and municipal foresight." ${ }^{\text {} 69}$ These "green ghetto[s] dedicated to the elite" in general "tended to remain a oneclass community, with just a sufficient fringe of tradesmen and servants to keep it going - the latter often condemned to use the central metropolis as their dormitory. Segregation, in practice, means compulsory association, or at least cohabitation $[\ldots]$ Hence the great residual freedom of the suburbanite is that of locomotion. ${ }^{, 70}$

The fringe of tradesmen and servants for Miami's single-class suburbs came in part from the strictly segregated black community of Colored Town (later known as the Central Negro District and then Overtown) on the north end of downtown, continually condemned to plead in vain to the city's white leaders for equal access to paved roads and adequate municipal services. Miami's boosters consistently tracked the mileage of its paved roads to stress its modern development, but of the over fifty miles of paved roads by 1920 not even a quarter mile could be found in Colored Town. Through restrictive covenants, violence, red-lining, and blight clearance, Miami's white leaders, often in measured cooperation with black landlords who stood to gain from high demand for segregated housing, maintained the color and class lines. ${ }^{71}$ Local intransigence to the plight of Miami's segregated black communities eventually led to the

${ }^{69}$ Lewis Mumford, The City in History: Its Origins, Its Transformations, and Its Prospects (New York: Harvest, 1961), 492.

${ }^{70}$ Ibid., 494.

${ }^{71}$ N.D.B. Connolly, A World More Concrete: Real Estate and the Remaking of Jim Crow South Florida (Chicago, IL: University of Chicago Press, 2014), 30-33. 
federally-funded Liberty City project built five miles northwest of downtown and encouraged by white elites as a means to clear out Colored Town for more commercially-oriented development. ${ }^{72}$ Apropos of Mumford's schema for suburban development trends, urban geographer Harold M. Rose concluded in 1963 that for all of the black settlements in Miami, "one factor stands out, viz., its physical fragmentation [...] This physical fragmentation is essentially a function of proximity to places of employment in a service-oriented metropolitan area, but could hardly have occurred in anything other than a newly emerging metropolitan community., ${ }^{, 73}$ In other words, the legacy of suburban development by and for people of means contributed to the continued unequal access for black Miamians of the basic requirements of life.

Indifference to Miami's black communities by white civic leaders contrasted with efforts to incorporate suburbs as part of the city proper and to address issues of municipal service provisions. The July 10, 1921 ad for Montray in the New York Times quoted Miami booster and Chamber of Commerce President Everest G. Sewell: "Right here I want to say that Mr. Dumont, president of the Montray Corporation, is showing a fine spirit in advertising Miami so generously [...] If all interests in Miami will pull together on the same oar advertise and boost our city - our growth will even faster than we predict.. ${ }^{, 74} \mathrm{By}$

\footnotetext{
72 Raymond A. Mohl, "The Origins of Miami's Liberty City," Florida Environmental and Urban Issues, Vol. 12 (Jul., 1985): 9-12.

${ }^{73}$ Harold M. Rose, "Metropolitan Miami’s Changing Negro Population, 19501960,” Economic Geography, Vol. 40, No. 3 (Jul., 1964): 238.

${ }^{74}$ Ad 72, New York Times, Jul. 10, 1921, 29.
} 
1927, George Merrick's lawyer, Clifford Benson, wrote that he perceived a crisis in "greater Miami," that Miami should look to New York City's borough system as a model of government, and that advertisements should be united to present the city as a whole instead of a group of smaller towns. ${ }^{75}$ The perceived crisis in part concerned the provision of municipal services to unincorporated areas outside Miami city limits, with the glaring exception of black communities. Already in September 1925, despite protests from several notable residents, including Ralph Munroe, a vote passed to annex to Miami the surrounding communities of Silver Bluff, Little River, Lemon City, Coconut Grove, Buena Vista, and Allapattah, increasing the size of the city from thirteen to forty-three square miles. ${ }^{76}$ Outside capital from the American Power and Light Company created Florida Power and Light (FPL) in 1924 to take over failing utility service providers throughout Miami and its suburbs. By 1926, FPL budgeted $\$ 28,000,000$ in utility construction for south Florida, the largest utility expenditure in U.S. history at the time. $^{77}$

In a December 1929 issue of the North American Review, Miami Herald writer Jack Kofoed made clear the contradictions between Greater Miami’s selfperception as a series of small, well-ordered, morally upright subdivisions of

${ }^{75}$ Letter from Clifford Benson to George Merrick, Jun. 24, 1927, Folder 1958003, 1-2, George Merrick Papers, Box 1, Charlton W. Tebeau Research Library, HistoryMiami.

${ }^{76}$ Frank Sessa, "Miami in 1926," 17; see also, Grant Livingston, "The Annexation of the City of Coconut Grove," Tequesta, Vol. 60 (2000): 32-55.

${ }^{77}$ Kenneth Ballinger, Miami Millions, 28. 
churches, schools, and clean recreation, and the actual sprawling, burgeoning metropolis and its many vices. "Miami continued to pretend that it was wrapped in civic righteousness," Kofoed prodded, "But in fact, and pretense aside, the Magic City has torn itself away from the staid old dream [...] The average visitor is much more likely to ask the location of a famous gambling joint, popularly supposed to have been backed by the late Tex Rickard, than of the First Methodist Church." "78 "Hypocrisy," he continued, "is increasing on the shores of Biscayne Bay. Get the dollars, but deny the reasons for them [....] My quarrel with Miami is not for the things she does or permits to be done within her borders, but for pretending that those things do not exist." ${ }^{, 79}$ Such hypocrisy could only be maintained because of Miami's myth-making architecture, suburban growth, and the escape from civic responsibility that suburban life fostered. Despite some improvements in metropolitan management, including increased capacity of water infrastructure, the civic landscape persisted in its fractured state of competing and inadequate municipal service directives. ${ }^{80}$

Hypocrisy likewise surfaced in the immediate aftermath of the 1929 financial crash that saw nearly all of greater Miami’s banks close their doors and leave many depositors empty-handed, a connected but often overlooked result of

${ }^{78}$ Jack Kofoed, “Miami,” North American Review, Vol. 228, No. 6 (Dec., 1929): 670.

${ }^{79}$ Ibid., 671.

${ }^{80}$ For problems and attempts to resolve issues of municipal water service, see L.R. Howson, "New Miami, Florida Water Softening Plant," American Water Works Association, Vol. 18, No. 4 (Oct., 1927): 442-454. 
suburban development. Lawyer and historian Raymond Vickers researched previously sealed bank records throughout Florida during the time of the real estate boom and subsequent bust. He found that every bank failure resulted from bankers' unauthorized uses of customer deposits to make private loans to themselves for real estate development. Widespread corruption and collusion between bankers, real estate developers, and bribed state officials, including Florida's comptroller Ernest Amos, hid the speculative, high-risk activity from the public, despite prevailing discourses of longevity, tradition, and decades of supposedly stable growth. Amos, later indicted, publically promoted the health of banks he knew were under water, which helps explain how many banks kept business going after the real estate market deflated in $1926 .{ }^{81}$ Praised by a May 20, 1933 edition of the Saturday Evening Post, titled, "Why Some Banks Fail and Others Don't," the First National Bank of Miami, the only major bank left after 1929, survived both the real estate bust and the stock market crash because it refused to engage in private loans of deposited capital like its contemporaries and thus remained in liquidity even after several runs from nervous depositors. ${ }^{82}$ Several of the most prominent Miami developers went the way of the banks. Carl Fisher, with so much of his wealth tied up in Miami Beach real estate, lost considerably from the 1926 hurricane, and he overextended his wealth further

${ }^{81}$ Raymond Vickers, Panic in Paradise: Florida's Banking Crash of 1926 (Tuscaloosa, AL: University of Alabama Press, 1994).

82 Garet Garrett, "Why Some Banks Fail and Others Don't," Saturday Evening Post, Vol. 203, No. 47 (May 20, 1933), copy from Southeast Bank Records, 1993008, Box \#1, Folder 1, Charlton W. Tebeau Research Library, HistoryMiami. 
by sinking $\$ 12,000,000$ into a "Miami Beach of the North" development at Montauk, Long Island, but losses from the hurricane and the stock market crash forced him into bankruptcy before his death in $1939 .{ }^{83}$ George Merrick lost his controlling stake in the Coral Gables development group after a series of defaults on public bond issues owed to a syndicate of bankers based in Baltimore that invested millions in his community improvement plans in 1927. Merrick attempted to regain his finances by opening a fishing resort on Matecumbe Key called the Matecumbe Caribee Colony, but the Labor Day hurricane of September 5, 1935, destroyed it. ${ }^{84}$ Added insults arrived shortly thereafter when Merrick was summoned to testify before the Securities and Exchange Commission on September 16 as to the nature of the defaults and reorganization of the Coral Gables development group. ${ }^{85}$

The legacy of privately led community development, and its shortcomings, continued to affect Miami as it entered a second major phase of growth after World War II, with reoccurring problems related to rapid growth that sounded a lot like the 1920s. In a 1955 report by the Chicago-based Public Administration Service, Wendell Schaeffer observed that in Miami,

The most pressing need is for governmental action on an areawide basis to provide such fundamental services as an adequate water system, an integrated

${ }^{83}$ Debbie Tuma, "Montauk Embraces Its Legacy," New York Times, Aug. 11, 2002, LI 11.

${ }^{84}$ Correspondences contained in George Merrick Papers, Box \#2, Folder 1958003, Charlton W. Tebeau Research Library, HistoryMiami.

85 "SEC Sifts Profits in Florida's Boom,” New York Times, Sep. 17, 1935, 33. 
sewage and waste disposal system, a network of major thoroughfares and expressways, and the kind of metropolitan planning that can guide and direct development of these services in an orderly manner, with a view not only to the immediate but to the long-range demands of the entire metropolitan area. In Miami, because of the extremely rapid pace of its growth, long range means tomorrow morning, early. $^{86}$

In other words, suburban development continued unabated despite the failure of so many suburbs to fulfill the basic needs of its residents. The recommended changes from the Public Service Administration review included the establishment of a metropolitan commission board composed of an at-large elected president and ten board members, with eight of the ten members elected from uniformly divided metropolitan units, irrespective of incorporated city limits, and one more elected from Miami and one from Miami Beach. ${ }^{87}$ In July 1957, Metropolitan Dade County government, simply called Metro, was established and began presiding over the city after a successful home rule charter amendment passed at the state level in 1956 and as well as a vote of confidence that year at the county level. Metro constituted the first metropolitan governmental organization formed in the United States, resulting in merged governing functions of a city and county. ${ }^{88}$ Continued votes throughout the

${ }^{86}$ Wendell G. Schaeffer, "Miami Looks at the Problems of Metropolitan Government," Public Administration Review, Vol. 15, No. 1 (Win., 1955): 36-37.

${ }^{87}$ Ibid., 37.

${ }^{88}$ Edward C. Banfield, Big City Politics - A Comparative Guide to the Political Systems of Atlanta, Boston, Detroit, El Paso, Los Angeles, Miami, Philadelphia, St. Louis and Seattle (New York: Random House, 1965) 94-106; Reinhold P. Wolff, Miami Metro: The Road to Urban Unity (Coral Gables, FL: University of 
second half of the twentieth century altered or expanded the scope of Metro governance, eventually leading to the vote in 1996 for a strong county mayoral role and the changing of the county name to Miami-Dade County. Greater Miami's need for metropolitan government resulted from decades of unchecked, ill-planned suburban development, symptomatic of the 1920s real estate boom's lasting impact.

\section{Conclusion: Postmodern Spanish Revival in the Metro and Suburbs in the}

Sky

By the 1930s, most architects abandoned the Spanish styles that pervaded Miami in favor of a modernist style, with significant extant examples of Art Deco, European International, and by mid-century, Miami Modernist, or MiMo, architecture. ${ }^{89}$ Philip Johnson, architectural department founder at New York's Museum of Modern Art in the 1930s responsible for introducing U.S. audiences to Le Corbusier and securing the political exile of Bauhaus founder Ludwig Miers van der Rohe to the U.S., shocked Miamians when he unveiled his plans for the Metro-Dade Cultural Center in downtown, completed in 1982. The design reflected the durability of Spanish and Mediterranean styles, with a large exposed central plaza surrounded in a covered processional by red barrel-tiled structures

Miami, 1960); Edward Sofen, A Report on Politics in Greater Miami (Cambridge, MA: Joint Center for Urban Studies of MIT and Harvard University, 1961); see also, Nicholas N. Patricios, Building Marvelous Miami, Appendix B.

${ }^{89}$ Russell T. Pancoast, "Miami Architecture So Far," in A Guide to the Architecture of Miami (Miami: Florida South Chapter, American Institute of Architects, 1963). 
addressed toward the plaza's center, with the entire design elevated a story above street level. In an interview with Hap Hatton, Johnson remarked that, "In Miami we had a very interesting tradition on our hands. So for heaven's sake, why not build on it?"90 Symbolic of the metropolitan growth and need for a cultural institution of that scale, the design imperative of Miami's initial suburbanization had come full-circle.

Several skyscraper condos in downtown Miami on Brickell Avenue, the former promenade of Millionaire's Row, first rose in the late-1990s and have continued ever since. Intended as a means of achieving greater urban density in a metropolis still struggling with the legacy of suburbanization, the end result of Brickell condo construction more closely resembles vertical suburbs than a genuinely urban environment. Lack of green spaces, exclusionary pricing, and included internal parking spots all contribute to gated-community-like towers where residents live in isolation from one another and use their access to cars to travel to more desirable, authentic parts of the city. ${ }^{91}$ The high-rises on Brickell represent the latest in nearly a century's worth of elite-driven development that leaves unexamined the attendant social costs of progress at the expense of community-centered growth.

\footnotetext{
${ }^{90}$ Hap Hatton, Tropical Splendor, 125; the Metro-Dade Cultural Center is the home of HistoryMiami and the downtown branch of the Miami-Dade Public Library.

${ }^{91}$ Craig Chester, "Miami’s Suburbs in the Sky," Next City, May 21, 2012.
} 


\section{CHAPTER IV}

\section{Empire's Ascent: Planes, Markets, and the Air-merican Century}

Airplanes more than any other means of transportation facilitated Miami's interconnection with the Americas and the wider world. From humble beginnings in the 1910s, the city's aerial history took flight alongside broader geopolitical processes, as wartime and peacetime imperatives accompanied shifting growth spurts in local civilian, commercial, and military aviation infrastructure and investment. The consequences of Miami's aviation history are manifold and global.

In its infancy, flight required an invented language to reflect its novelty. New words like "air-mindedness" and "air wise" and puns like "personAIRlities" pervaded military pronouncements and aeronautical trade publications, and a dictionary of over 5,000 words published in 1911 recorded and defined the neologisms and new compound words for a curious public. ${ }^{1}$ In that spirit, I argue

${ }^{1}$ Some of the trade journals considered below include Aeronautics and Aero Digest, which exhibited much of this new language. The dictionary referenced is Robert Morris Pierce, Dictionary of Aviation (New York: Baker \& Taylor, 1911). For scholarly assessments of air-mindedness in Europe and the U.S., see Peter Adey, "Ten Thousand Lads with Shining Eyes Are Dreaming and Their Dreams Are Wings': Affect, Airmindedness and the Birth of the Aerial Subject," Cultural Geographies, Vol. 18, No. 1 (Jan., 2011): 63-89; Scott W. Palmer, "On Wings of Courage: Public 'Air-mindedness' and National Identity in Late Imperial Russia," The Russian Review, Vol. 54, No. 2 (Apr., 1995): 209-226; Palmer, "Peasants into Pilots: Soviet Air-Mindedness as an Ideology of Dominance," Technology and Culture, Vol. 41, No. 1 (Jan., 2000): 1-26; Peter Fritzsche, "Machine Dreams: Airmindedness and the Reinvention of Germany," American Historical Review, Vol. 98, No. 3 (Jun., 1993): 685-709; Ann Douglas, "Skyscrapers, Airplanes, and Airmindedness: 'The Necessary Angel'," in The Jazz Cadence of American Culture (New York: Columbia University Press, 1998) edited by Robert G. O'Meally, 196-224. A critical look at literary reflections of flight and the radical changes engendered to the idea of a nation as an island can be found in Gillian 
that colluding U.S. commercial and military interests vied with foreign competitors for control of the skies. In securing and maintaining that control, U.S. investors, policymakers, and military leaders engaged in a process that I call airgemony, a constellation of coercive, clandestine, and, at times, overt mechanisms of air dominance designed to limit competition and secure acquiescence to U.S. power in the form of provisioned military bases, favorable terms of trade, and support for foreign governments that espoused a capitalist ideology. Individuals, institutions, and corporations, acting as agents of U.S. imperial ambition, attempted to control regional, hemispheric, global, and, eventually, extraterrestrial airways through airmail contracts, airport improvement plans, and military aid packages. ${ }^{2}$

Beer, "The Island and the Aeroplane: The Case of Virginia Woolf," in Nation and Narration (New York: Routledge, 1990), edited by Homi K. Bhabha, 265-290; see also, Robert Wohl, A Passion for Wings: Aviation and the Western Imagination, 1908-1918 (New Haven, CT: Yale University Press, 1994); the potential of flight for new perspectives on urban design is best articulated in Le Corbusier, Aircraft (London: Trefoil, 1935); see also, M. Christine Boyer, "Aviation and the Aerial View: Le Corbusier's Spatial Transformations in the 1930s and 1940s," Diacritics, Vol. 33, No. 3/4 (Aut.-Win., 2003): 93-116.

${ }^{2}$ Jenifer Van Vleck, Empire of the Air: Aviation and the American Ascendancy (Cambridge, MA: Harvard University Press, 2013); Jeffrey A. Engel, Cold War at 30,000 Feet: The Anglo-American Fight for Aviation Supremacy (Cambridge, MA: Harvard University Press, 2007); Matthew Josephson, Empire of the Air: Juan Trippe and the Struggle for World Airways (New York: Arno Press, 1972); Robert Winston Hawes, "The Empire of Pan American Airways," (MBA Thesis, Boston University, 1943); Alan P. Dobson, "The Other Air Battle: The American Pursuit of Post-War Civil Aviation Rights," The Historical Journal, Vol. 28, No. 2 (Jun., 1985): 429-439; David T. Courtwright, Sky as Frontier: Adventure, Aviation, and Empire (College Station, TX: Texas A\&M University Press, 2005); Roger E. Bilstein, Flight in America: From the Wrights to the Astronauts (Baltimore, MD: Johns Hopkins University Press, 2001); Max Paul Friedman, Nazis and Good Neighbors: The United States Campaign Against the Germans in Latin America in World War II (New York: Cambridge University Press, 2003). 
This chapter investigates the ways in which Miami actively participated in the growth and maintenance of U.S. airgemony in Latin America and beyond. Commercial aviation linked Miami to points south and north. The first two sections of the chapter explore how early aviation history bound the city to the Caribbean in particular, and how major airlines like Pan American Airways, Eastern Airlines, National Airlines, and Delta Airlines all grew by servicing the city. Indeed, aviation remains the largest employer in Miami-Dade County. ${ }^{3}$ Military pilots and officers for both world wars trained in the city, a military coup in Guatemala that employed novel techniques of psychological warfare by air was planned and coordinated from a Miami airport, and Latin American cold warriors practiced in Miami for clandestine services throughout the world. The third section shows that strategies of state and non-state counter-airgemony likewise worked through the city. The disastrous Bay of Pigs air invasion began and ended on Miami airfields, and the city acted as the forward nuclear base during the Missile Crisis. Propaganda and disinformation beamed from Miami over radio and television airwaves via experimental aircraft contributed nuanced strategies of

\footnotetext{
${ }^{3}$ William C. Lazarus, Wings in the Sun: The Annals of Aviation in Florida (Orlando, FL: Tyn Cobb's Florida Press, 1951); Aurora E. Davis, "The Development of the Major Commercial Airlines in Dade County, Florida: 19451970," Tequesta, Vol. 32 (1972): 3-16; Kenneth Gaulin, “The Flying Boats: Pioneering Days to South America," Journal of Decorative and Propaganda Arts, Vol. 15 (Win.-Spr., 1990): 78-95; William E. Brown, Jr., "Pan Am: Miami's Wings to the World," Journal of Decorative and Propaganda Arts, Vol. 23 (1998): 144-161; "Miami International Airport, U.S. and World Airport Rankings, Passengers and Flights, 2014," (Miami, FL: Miami-Dade Aviation Department Marketing Division, 2015); "Miami-Dade Aviation: Facts at a Glance," www.miami-airport.com/facts.asp.
} 
maintaining airgemony. ${ }^{4}$ Beginning in the 1960s, planes bound for Miami became the main source of plunder for "air pirates" on their way to freedom from U.S. jurisdiction in Cuba. The modern airplane and airport security protocols, including the use of air marshals and screening processes, stemmed from struggles in the air over the Florida Straits. ${ }^{5}$ Such a context in part helps explain how several hijackers utilized civilian flight training facilities in south Florida to execute the deadliest attack on U.S. soil in history.

\section{Taxiing Down the Runway: Early Flight and Air-Mindedness in South}

\section{Florida}

Only fifteen years elapsed between the arrival to Miami of the first train and the first flying machine. In preparation for Miami's fifteenth anniversary celebration slated for July 20, 1911, Everest Sewell solicited the Wright brothers to conduct a flying demonstration in Miami as part of the festivities. For $\$ 7,500$, the Wrights sent Howard Gill, an aviator from Baltimore, to conduct the demonstration on their behalf (Fg. 4.1). The spectacle drew the largest crowd ever assembled in the small city at that time. According to the oral history of Hoyt

${ }^{4}$ Jack B. Pfeiffer, Official History of the Bay of Pigs Operation, Vol. 1, Air Operations, March 1960 - April 1961, Part 1 (Langley, VA: Central Intelligence Agency, 1979, sanitized and approved for release July 25, 2011); Piero Gleijeses, "Ships in the Night: The CIA, the White House and the Bay of Pigs," Journal of Latin American Studies, Vol. 27, No. 1 (Feb. 1995): 1-42; Peter Kornbluh, Bay of Pigs Declassified: The Secret CIA Report on the Invasion of Cuba (New York: New Press, 1998); Steve Hach, Cold War in South Florida: Historical Resource Study (Atlanta, GA: Department of Interior - National Parks Service, 2004).

5 Seymour W. Wurfel, “Aircraft Piracy - Crime or Fun?” William \& Mary Law Review, Vol. 10, No. 4 (1969): 820-873. 
Frazure, a young boy in 1911, cows broke down fences and chickens flew from their coops because of the plane's unfamiliar and overwhelming noise. ${ }^{6}$

Reflecting the inherent dangers of early aviation, Howard Gill died a year after his Miami demonstration when his plane collided midair with the plane of a French aviator, George Metach, during a flight meet in Chicago. ${ }^{7}$ Although flight sparked the imagination of the Western world, the real risks involved made most Americans hesitant to see flying as anything more than a spectacular curiosity, a stance only ameliorated with government regulation, safer planes, and improved infrastructure of the late $1920 \mathrm{~s}^{8}$

${ }^{6}$ Thelma Peters, "Miami's First Plane," Update, Vol. 12, No. 4 (Nov., 1985): 3-4; Hoyt Frazure with Nixon Smiley, Memories of Old Miami (Miami: Miami Herald, 1964), 11; William C. Lazarus, Wings in the Sun, 35.

7 “'Aviator Killed in Midair Collision; Howard Gill Hurled 200 Feet to Ground in Crash at Chicago Meet," New York Times, Sep. 15, 1912.

${ }^{8}$ David T. Cartwright, Sky as Frontier, 3-88; Robert Wohl, A Passion for Wings. 


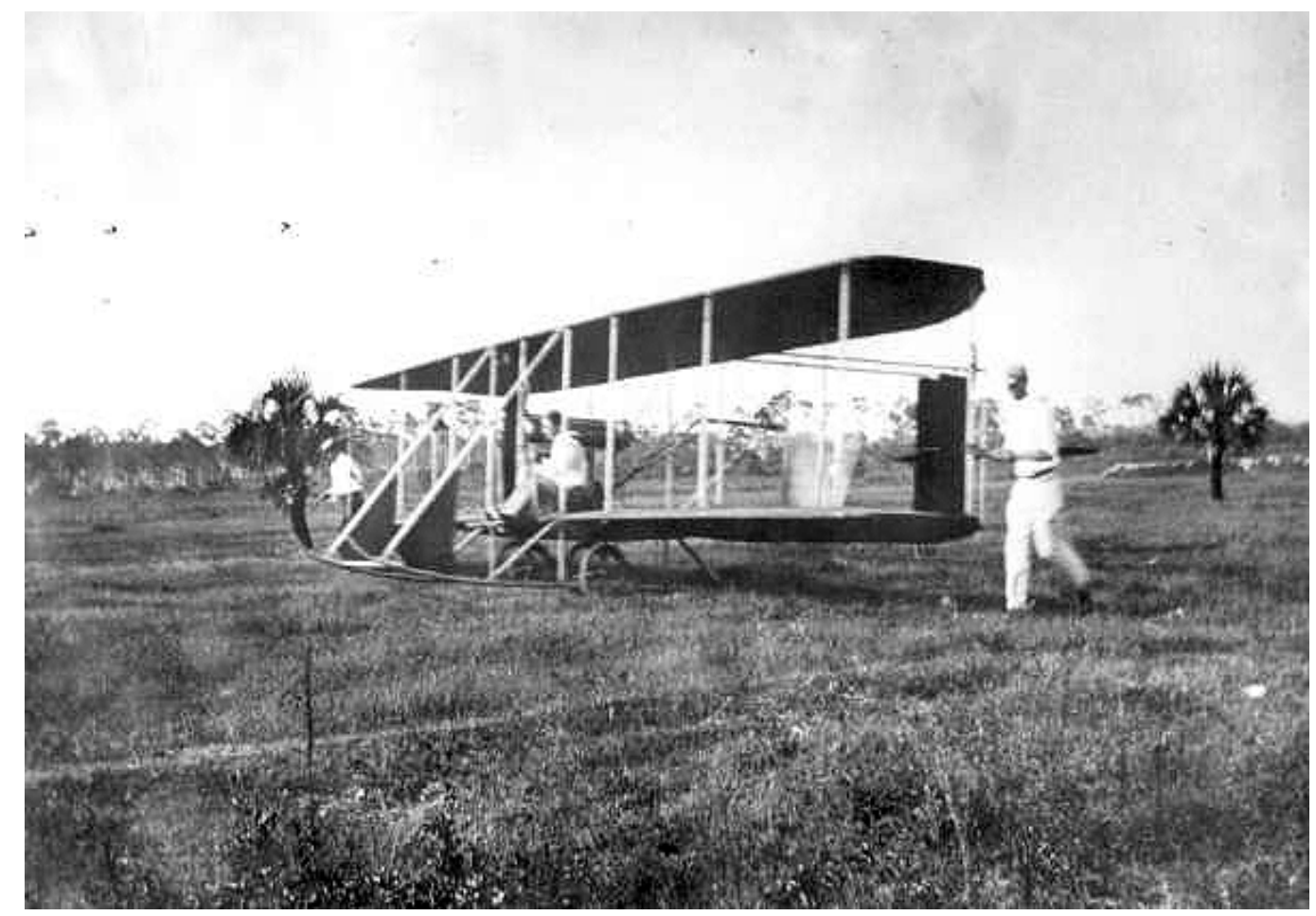

Figure 2 Frank B. Davis, "Winged Aircraft Flown by Howard Gill - Miami, Florida," 1911, State Archives of Florida, Florida Memory.

Despite the risks, Everest Sewell and other Miamians became "air wise" with Gill's demonstration. The Wrights declined Sewell's invitation to create a flying school in Miami, but Glenn Curtiss accepted the invitation. The Curtiss Flying School initiated land and seaplane training in the winter of 1911-1912 to complement the training done during warmer months at Curtiss's flying school in Hammondsport, New York. Curtiss hired Hoyt Frazure's father, a local contractor, to make the landing field, which he did on the site of an old potato field at NW 17th Avenue and 20th Street. Seaplane training operated from the Royal Palm Hotel's docks on Biscayne Bay. A January 1912 edition of Aeronautics magazine advertised the Miami school with a bold typeface declaring 
that, "The Curtiss schools are the only ones teaching the pupil to use both the aeroplane and the hydroaeroplane." ${ }^{9}$

The Curtiss Flying School trained one of Cuba's first pilots in Miami, the first instance of air links between Havana and Miami. Augustin Parlá, born in Key West to exiled Cuban parents, along with three Americans, earned the first wings conferred by the Miami school. Encouraged by a $\$ 10,000$ reward from Havana's government in 1911 to successfully fly a plane over the Florida Straits, Parlá and Domingo Rosillo del Toro, who trained in Paris, each completed the flight from Key West to Havana in May of 1913, with Rosillo beating out Parlá for the honor. Parlá received \$5,000 for second place, and both men promoted the growth of aviation in Cuba and its aerial links to south Florida as a result. ${ }^{10}$

Domestic military spending for aviation reached unprecedented heights with the onset of hostilities in Europe in 1914. The U.S. entered the Great War on April 6, 1917. On July 24, Congress appropriated $\$ 640$ million for aircraft production, training, and airport construction, with at least $\$ 80$ million in contracts awarded to Curtiss. ${ }^{11}$ For $\$ 1$, Curtiss lent the Marines his Miami flying

\footnotetext{
9 “Curtiss Flying School," Aeronautics, Vol. 10, No. 1 (Jan., 1912): 12, 19; Frazure, Memories of Old Miami, 11-12; Linda K. Williams, "The School for Famous Flyers: Reminiscence of Charles Christian Witmer," Update, Vol. 12, No. 4 (Nov., 1985): 4-5.

${ }^{10}$ Dan Hagedorn, Conquistadors of the Sky: A History of Aviation in Latin America (Gainesville, FL: University Press of Florida, 2008), 57-61; Cammy Clark, "100 Years Ago, Aviation Pioneer Made Historic Flight from Key West to Cuba," Miami Herald, May 16, 2013.

11 "Aircraft Production in the United States," United States Senate, 65th Congress, 2nd Session, Report No. 555, Aug. 22, 1918; Cecil R. Roseberry, Glenn Curtiss: Pioneer of Flight (Syracuse, NY: Syracuse University Press, 1972), 428-429.
} 
field and training planes, which was renamed Marine Flying Field and constituted the first Marine Air Force field ever acquired for that branch of the military. ${ }^{12}$ The Navy based its local air training at Dinner Key off Coconut Grove, and commissioned a dredge to connect the key to the mainland. During Dinner Key's construction, the Navy used the former Curtiss seaplane docks at the Royal Palm Hotel. In 1919, the Army Signal Corps, the forerunner to the Army Air Forces, chose a site south of Miami in Cutler on what was renamed Chapman Field to honor the first American airman killed in the war, Victor Chapman. ${ }^{13}$

The Marine occupation of the Dominican Republic from 1919 to 1924 and in Haiti from 1919 to 1934 flew occupying forces to and from the Miami field, and wounded troops in both occupying theaters were airlifted back to Miami for treatment. Marine officers trained in Miami also led the occupation of Nicaragua from 1927 to 1933. The first use of dive-bombing against an organized enemy, where a plane dives steeply downward toward a target as it releases the bomb, occurred against the supporters of Augusto Sandino in Nicaragua, which also marked the first use of air-to-ground communications during combat. ${ }^{14}$ The

${ }^{12}$ A Brief History of Marine Corps Aviation (Washington, DC: Department of the Navy Headquarters United States Marine Corps, 1962), 1-3; Amanda S. Ridings, "Wings Over Miami," Update, Vol. 12, No. 4 (Nov., 1985): 8.

${ }^{13}$ Ridings, "Wings Over Miami," 8; Raymond G. McGuire, "Chapman Field The Evolution of a South Dade Army Airdrome," Tequesta, Vol. 51 (2001): 5859; Lazarus, Wings in the Sun, 46-58.

${ }^{14}$ A Brief History of Marine Corps Aviation, 3-4; Roger E. Bilstein, Flight in America: From the Wrights to the Astronauts (Baltimore, MD: Johns Hopkins Press, 2001), 45-46; for much more on the imperial dimension of Marine aviation during the U.S. occupation in Santo Domingo and the culture of flight created there, see Eric Paul Roorda, "The Cult of the Airplane among U.S. Military Men 
projection of U.S. airgemony from Miami continued in various forms for decades to come.

The cessation of World War I flooded the domestic market with surplus military planes, severely depressing civilian airplane production. The sudden availability of cheap planes offered opportunities, though, for experimental commercial aviation. ${ }^{15}$ In 1919, Aero Limited of New York and Miami began promotional flights on former Navy F-5-L twin-engine Liberty seaplanes, stopping at many cities in an effort to secure local landing spaces along the route between the two cities. Harry Rogers served as one of the pilots for Aero Limited, experience he later put to use with his own air service in Miami the following year. ${ }^{16}$

Several commercial ventures attempted to secure the aerial routes between Miami and Caribbean destinations. A short-lived company based in Havana, Cuban-American Aviation Company, attempted service between Havana and Key West, but lack of interest and capital folded the company within six months. The

and Dominicans during the U.S. Occupation and the Trujillo Regime," in Close Encounters of Empire: Writing the Cultural History of U.S.-Latin American Relations (Durham, NC: Duke University Press, 1998), 269-310; for more on the occupation in Haiti, see Mary A. Renda, Taking Haiti: Military Occupation and the Culture of U.S. Imperialism, 1915-1940 (Chapel Hill, NC: University of North Carolina Press, 2001); a critical comparative look at two periods of U.S. occupation in Nicaragua is presented in Michael J. Schroeder, "Bandits and Blanket Thieves, Communists and Terrorists: The Politics of Naming Sandinistas in Nicaragua, 1927-36 and 1979-90," Third World Quarterly, Vol. 26, No. 1 (2005): 67-86.

${ }^{15}$ Lazarus, Wings in the Sun, 61-62.

16 “An Air Transport Record," Aviation and Aircraft Journal, Vol. 9, No. 11 (Nov. 29, 1920): 345. 
U.S.-based Aeromarine Airways had better luck when it purchased seaplanes from the Navy and began a six-passenger air service from Key West to Havana on November 1, 1920, marking the first international commercial flight in U.S. history. Although not considered a regular service compared to later airlines, the non-scheduled charter flights of Aeromarine, mostly during winter months, accelerated the growing links between south Florida and the Caribbean and dramatically shortened travel times. By 1922, and in the context of Prohibition, Aeromarine offered its wealthy winter clientele daily flights from Miami to enjoy the prohibited pleasures of Caribbean rum in Bimini and Nassau on the Bahamas, nicknamed the "Liquor Islands." ${ }^{, 17}$ Aeromarine also started the trend of naming its planes after Spanish explorers like Columbus, followed later by Pan American Airways and the NASA Space Shuttle program (Fg. 4.2). Just as Spanish architecture naturalized suburban settlement on a former colonial frontier, so too did a gesture to the Age of Exploration situate the ascendancy of U.S. airpower in world-historical terms.

${ }^{17}$ Lazarus, Wings in the Sun, 61-62; Ridings, "Wings Over Miami," 7; Johnson Wright, "Florida Air News," Aero Digest, Vol. 13 (Jul., 1928): 164. 


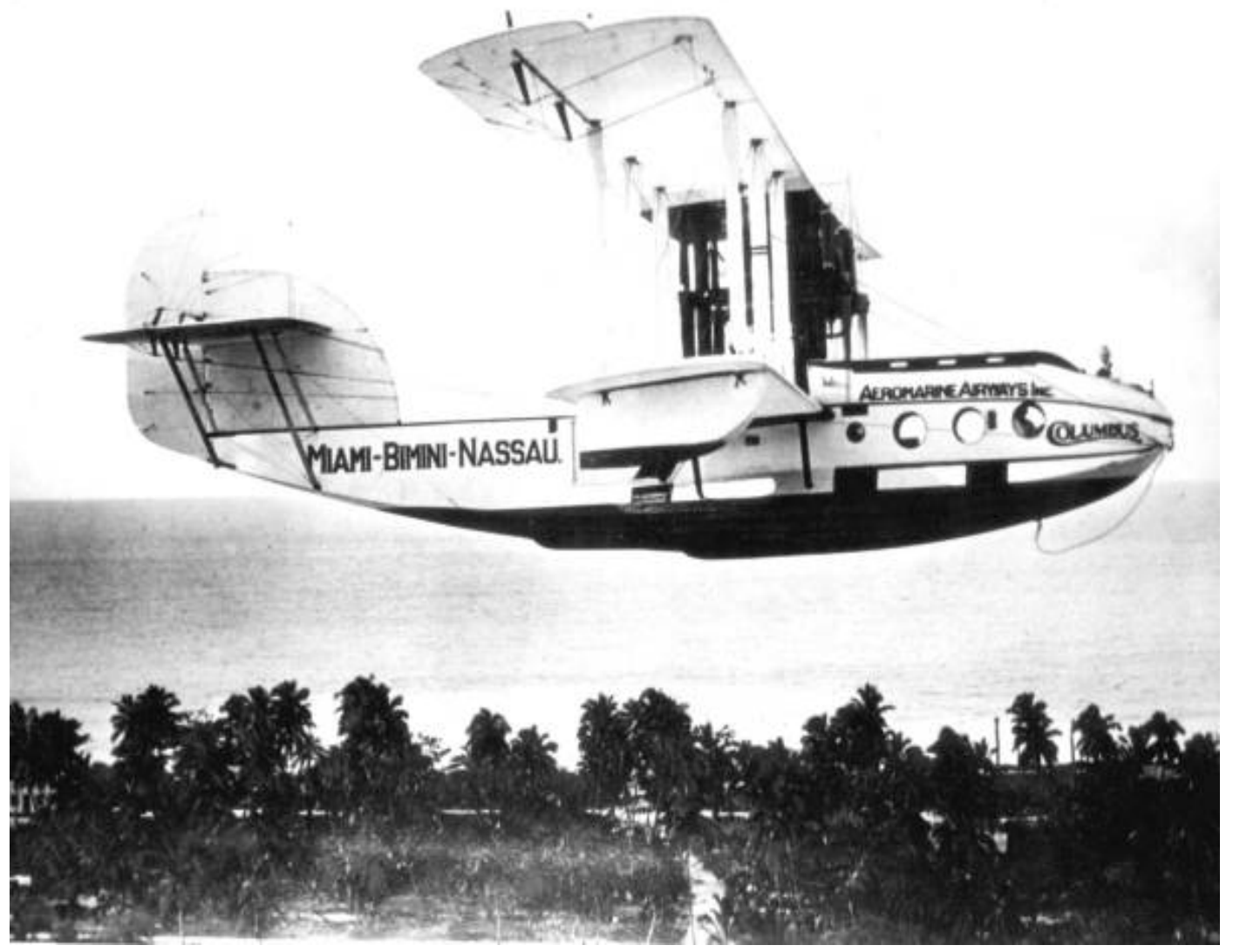

Figure 3 "Seaplane in Flight," with Miami-Bimini-Nassau route listed on tail, and Columbus on the nose. January 17, 1922, State Archives of Florida, Florida Memory.

Two additional operations expanded the aerial portfolio of Miami’s civilian training and charter flights to the Caribbean. Arthur Chalk started his Chalk Flying School in 1919 on the County Causeway between Miami and Miami Beach. Chalk helped interested flyers earn their wings and chartered flights to Cuba and the Bahamas beginning in the 1920s. He moved his operation to the landfilled Watson Island south of Miami Beach in 1926, and the company maintained services from Watson Island throughout the twentieth century. ${ }^{18}$ Chalk's school garnered a reputation as one of the best training and charter services in the United States because of his unblemished record of flight safety, as

${ }^{18}$ Ridings, "Wings Over Miami," 7. 
noted in the July 1928 edition of Aero Digest. ${ }^{19}$ Harry Rogers of New York established flying boat service from Royal Palm Park in downtown Miami in 1920 after working for Aero Limited, and he chartered flights to the Bahamas and Cuba in addition to organizing sightseeing tours of Miami and south Florida. ${ }^{20}$ Flight facilitated the pleasurable transgression of nominal U.S. sovereignty and provided the aerial means of escape from the strictures of Prohibition, a pattern later to include the importation by air of illicit cocaine into Miami during the 1970s-1980s.

Experimental military, commercial, and private enterprises thus propped up Miami's early aviation industry from the 1910s through much of the 1920s. Costs and risks outweighed potential benefits to sustain activity for investors and consumers both locally and around the country, and Miami's local aerial activity was not without competition. Civilian and military champions of the industry in Washington feared the progress through the air being made by foreign nations in Europe and closer to home, particularly in Colombia as discussed below. Federal legislation and incentives enacted in the mid-1920s aimed to correct the imbalance and to regain the aerial advantages of a homegrown industry. Aviation matured by the end of the decade with steadier federal support and increasingly solid guarantees of profit. ${ }^{21}$

\footnotetext{
${ }^{19}$ Johnson Wright, "Florida Air News," Aero Digest, Vol. 13 (Jul., 1928): 164.

${ }^{20}$ Lazarus, Wings in the Sun, 68; Ridings, "Wings Over Miami," 7; Wright, "Florida Air News," 164.

${ }^{21}$ Courtwright, Sky as Frontier, 64-69; Bilstein, Flight in America, 50-59; Lazarus, Wings in the Sun, 86-90.
} 


\section{Cleared for Takeoff: Airgemony Comes of Age}

Three federal laws incentivized the maturity of commercial aviation in the United States. The first two, the Air Mail Act of 1925 and the Air Commerce Act of 1926, codified the rules and regulations whereby the Post Office and the Postmaster General contracted with private companies for domestic air transport of mail and passengers. ${ }^{22}$ Florida Airways established the second scheduled airmail service in the country on April 1, 1926 between Tampa and Miami via Jacksonville. A group of investors that included the World War I ace Eddie Rickenbacker started the company, and Rickenbacker later headed Eastern Airlines and its base of operations in Miami. ${ }^{23}$ Because contracted airmail was initially calculated on a per pound basis, pilots for Florida Airways routinely inflated the weight of their carried mail by concealing bricks and other heavy items within their packages to increase revenues. The disingenuous practice prolonged the life of the struggling company, which never achieved either sufficient airmail or passenger activity and folded by the end of $1926 .{ }^{24}$ Congress

\footnotetext{
22 "Contract Air Mail Service," United States Senate, 68th Congress, 2nd Session, Report No. 864, Jan. 24, 1925; "Pay of Carriers for Contract Ail Mail Service," United States House of Representatives, 69th Congress, 1st Session, Report No. 1197, May 6, 1926; "The Promotion of Commercial Aviation," United States Senate, 69th Congress, 1st Session, Report No. 2, Dec. 14, 1925.

${ }^{23}$ Lazarus, Wings in the Sun, 83.

${ }^{24}$ Courtwright, Sky as Frontier, 67.
} 
amended the Air Mail Act in 1930 as a result of such practices to limit weight rates and include a calculation of traveling distance. ${ }^{25}$

President Calvin Coolidge, in an address before the Pan-American Conference in Havana in January 1928, foreshadowed the third federal law that would directly affect the entire hemisphere as well as Miami. In addition to the U.S. already sending military, naval, and engineering advisers throughout the Americas for road, railroad, and port construction, Coolidge promised to the conference attendees that, "These gratifying changes are about to be supplemented by the establishment of aviation routes, primarily for the transportation of mails, which will afford to our republics a channel of interchange which will find its ultimate expression in closer cultural and commercial ties and in better mutual comprehension. ${ }^{, 26}$ In hearings regarding the Foreign Ail Mail Act that followed Coolidge's address, Postmaster General Harry New echoed the president's sentiments, telling Congress that, "The countries to the south of us are anxious to participate in the development and benefits of ail mail service and, because of our present preeminence in the air, naturally look to the United States to provide the requisite facilities." 27

The Sociedad Colombo-Alemana de Transportes Aéreos (SCADTA) directly challenged Postmaster New's assertions. Formed in 1919 by German and

\footnotetext{
25 "Amend the Air Mail Act of February 2, 1925," United States House of Representatives, 71st Congress, 2nd Session, Report No. 966, Mar. 24, 1930.

26 “Full Text of President Coolidge's Address," New York Times, Jan. 17, 1928, 2. 27 "Air Mail to Foreign Countries and Insular Possessions of the United States," United States Senate, 70th Congress, 1st Session, Report No. 311, Feb. 15, 1928.
} 
Colombian citizens in Barranquilla, Colombia, SCADTA flew more miles and carried more mail and passengers than any comparable U.S. company in the 1920s. The company was so far ahead that it had already surveyed air routes from the Caribbean to Miami and applied for permission from the State Department to conduct flights to and from Miami by 1925. The State Department refused because of military security concerns, and the increased urgency of congressional legislation regarding foreign airmail service made sense in the context of a foreign company attempting to penetrate U.S. airspace and usurp potential revenue. ${ }^{28}$ Proposed amendments to the foreign airmail service in 1929 showcased U.S. anxiety rather than South Americans' search for leadership. In order to operate in Colombia, the Post Office would have to purchase Colombian postage as opposed to using U.S. postage, a complicated problem with no immediate solution. ${ }^{29}$

The solution to Colombia's challenge to U.S. airgemony was Pan American Airways, first created by Army Air Corps Major Henry "Hap" Arnold and two other military fliers in 1927. Underfunded from the start, the company earned the first mail contract to fly from Miami to Havana, but an upstart Yale graduate and former trainee at Miami's Dinner Key Naval station during World War I, Juan Trippe, along with his wealthy partners, acquired Pan American to take over the route. In October 1927, using a rented plane to make the deadline,

${ }^{28}$ Matthew Josephson, Empire of the Air, 43; H. Case Wilcox, "Air Transportation in Latin America," Geographical Review, Vol. 20, No. 4 (Oct., 1930): 592; Eduardo Posada Carbó, The Colombian Caribbean: A Regional History, 1870-1950 (New York: Oxford University Press, 1996), 173-174.

29 "Contracts for Transportation of Mail by Air," United States House of Representatives, 70th Congress, 2nd Session, Report No. 2330, Feb. 1, 1929. 
Pan American fulfilled its contract obligations and began regular mail service between Key West and Havana, moving permanently to Miami by the following year. Without federal help and funding, Pan American no doubt would have met the same fate as so many other fledgling airlines. Acquisitions more than anything facilitated the company's realization as the symbol of U.S. commercial airpower in Latin America and around the world. ${ }^{30}$

The State Department and the Postmaster General provided critical assistance possible through foreign representatives in Latin America to help secure rights for Pan American. In Mexico, Pan American acquired the Compañia Mexicana de Aviación, giving the company major routes throughout the country and controlling routes to the Canal Zone. Mexican companies continued to operate domestic routes, while Pan American received the international routes through Brownsville, Texas. Cuba and the Dominican Republic also early permitted exclusive contracts and flying rights to Pan American. Other nations reticent of U.S. imperial ambition, including Guatemala, Honduras, Venezuela, and Colombia, were less willing to submit their national airspace to Pan American's monopolistic demands. Working around unwilling partners, Pan American established routes that connected Cuba, the Dominican Republic, Puerto Rico, Mexico, the Canal Zone, and south to Peru and Chile by 1929, all of

${ }^{30}$ Jenifer Van Vleck, Empire of the Air, 65-67; Matthew Josephson, Empire of the Air, 31-33. 
which connected to the Miami Pan American airfield at NW 36th Street, on land donated for that purpose to the city of Miami by Glenn Curtiss. ${ }^{31}$

Pan American joined forces with the powerful shipping and guano export company W.R. Grace to form Pan American-Grace airlines for service on South America's west coast in Peru and Chile, known as Panagra, by 1929. Regular services as part of the Pan American system reached Lima by May and Santiago by July. Routes along the northeastern coast of the continent connected from Puerto Rico to Curaçao and Paramaribo, Dutch Guiana. Colombia's SCADTA, seeing their preeminence and potential expansion squeezed on all sides, secretly agreed to permit Pan American to purchase a controlling stake in the company for \$1.1 million, accompanied by a mutual reciprocity agreement signed between the United States and Colombia, known as the Kellogg-Olaya Pact. Another major competitor along South America's east coast was the New York, Rio, and Buenos Aires Airline (NYRBA) that received mail and passenger contracts in 1929 from Brazil and Argentina. The U.S. Post Office preferred Pan American, however, and without U.S. backing, the NYRBA was forced to sell its contracts and assets to Pan American in exchange for company stock. ${ }^{32}$ In the span of two years, Pan American's lines, underwritten by federal assistance, grew from 216 to 13,012 miles of air routes. ${ }^{33}$

${ }^{31}$ Josephson, Empire of the Air, 55-60; James Warner Bellah, "The MiamiPanama Air Mail Route,” Aero Digest, Vol. 14, No. 5 (May, 1929): 43-44.

${ }^{32}$ Josephson, 68-79.

${ }^{33}$ H. Case Wilcox, "Air Transportation in Latin America," Geographical Review, Vol. 20, No. 4 (Oct., 1930): 597. 
In Miami, Pan American's rapid growth met with enthusiasm at the prospect of renewed commercial growth for the city in the wake of the mid-1920s real estate bust. Clayton Sedwick Cooper, president of the elite Committee of 100 social club on Miami Beach first introduced in chapter two, tirelessly promoted Miami's aerial advantages. The Greater Miami Airport Association, formed in 1928, heard Cooper's speech, "City of Aviation," during an October 25 meeting. Cooper stressed Miami's leading position at the head of Pan American progress, and he predicted the city's prominent place in inter-American relations via the air. ${ }^{34}$ U.S. Army Chief of Staff Major General Charles P. Summerall spoke at the Committee in November 1929, toured local airport and seaport facilities, and likewise predicted Miami's future greatness as a base and commercial center because of its air-mindedness. ${ }^{35}$ Mayor-elect Fiorello LaGuardia, on a return Pan American flight from the Canal Zone in November 1933, visited the Committee and spoke of New York's need to follow Miami's example in building up its airport facilities. LaGuardia also predicted that air travel through Miami would foster better relations with Latin America. Mayor Everest Sewell, the original air-

\footnotetext{
${ }^{34}$ Clippings from Miami Herald and Miami Daily News, Oct. 24-25, 1928, in Clayton Sedwick Cooper Scrapbooks, Fall 1928-Spring 1929, Committee of 100 Scrapbooks 1925-29, 2007-008, Box 1, Charlton W. Tebeau Research Library, HistoryMiami.

${ }^{35}$ Clipping from Miami Daily News, Nov. 10, 1929, in Clayton Sedwick Cooper Scrapbooks, Fall 1928-Spring 1929, Committee of 100 Scrapbooks 1925-29, 2007-008, Box 1, Charlton W. Tebeau Research Library, HistoryMiami.
} 
minded Miami booster, gave LaGuardia a coconut for cracking the tough nut of Tammany Hall, reflecting the city’s elite tropical culture. ${ }^{36}$

A further enhancement of Miami's significance for the projection of airgemony began in 1928 with the Miami All-American Air Races, which exhibited many of the most experimental airplanes and dirigibles. The Goodyear dirigible "Defender" visited the air races in 1930. The U.S. Senate Public Lands Commission used the Defender to tour the proposed Everglades National Park. ${ }^{37}$ The USS Akron, the largest airship ever commissioned by the U.S. Navy, visited the air races in 1933, only months before it exploded during a thunderstorm in New Jersey killing 73 of 76 crew and passengers. ${ }^{38}$ Built at the Goodyear plant in Akron, Ohio, the helium-powered dirigible could carry planes within its bowels and allow for midair exit of airplanes, an experimental precursor to aircraft carriers. The Akron visited the Miami air races in 1933 on its way to Cuba as part of an exhibition of U.S. airpower in the Caribbean (Fg. 4.3). Speed tests achieved

${ }^{36}$ Clippings from Miami Herald and Miami Daily News, Nov. 22, 1933, in Committee of 100 Scrapbooks, 1933-34, 2007-008, Box 7, Charlton W. Tebeau Research Library, HistoryMiami; "LaGuardia Irked by News of Plans: Considers Flying to Miami to Escape Reporters - Decides to Go On to Panama," New York Times, Nov. 15, 1933.

${ }^{37}$ Clipping from Miami Herald, Dec. 29, 1930, in Clayton Sedwick Cooper Scrapbook, Fall 1930-1931, Committee of 100 Scrapbooks, 1930-31, Box 3, Charlton W. Tebeau Research Library, HistoryMiami.

38 "73 Lost in Akron Crash, 3 Survivors Here; Ship Driven Down in Storm, Cause is Unknown; Rescue Blimp Falls, 2 Killed, 5 Are Saved," New York Times, Apr. $5,1933$. 
at the 1934 and 1935 races broke national records, with maximum acceleration rates of $6.2 \mathrm{~g} \cdot{ }^{39}$

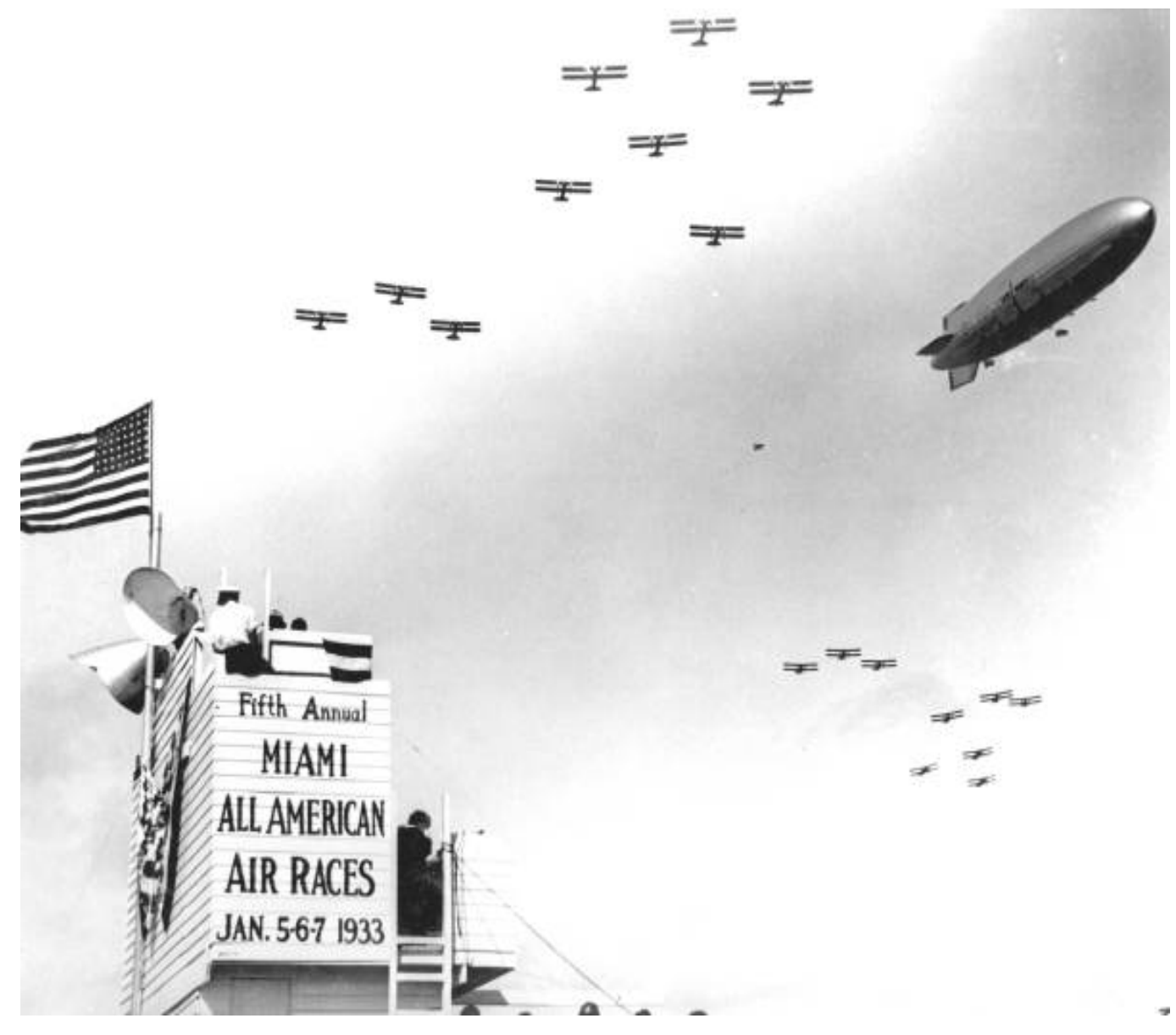

Figure 4 "Airship Akron Leaving for Cuba with Bomber Escort," Jan. 7, 1933, State Archives of Florida, Florida Memory.

Although boosters sought to promote Miami’s air infrastructure as a positive asset in linking the city with the hemisphere, increased international air travel to and from the city presented certain risks to public health. On July 23, 1931, the United States Public Health Service mandated the inspection of all Pan American airplanes arriving in Miami from tropical ports for possible carriage of

${ }^{39}$ N.F. Soudder and H.W. Kirschbaum, A Preliminary Determination of Normal Accelerations of Racing Airplanes, Technical Note No. 537 (Washington, DC: National Advisory Committee for Aeronautics, 1935), 1. 
yellow fever-inducing mosquitoes. In 102 inspections conducted from July 23 to September 12, officials discovered twenty-nine mosquitoes on a total of twentyone flights, or roughly a twenty percent occurrence rate for in-bound flights. ${ }^{40} \mathrm{By}$ 1937, the Public Health Service and Pan American agreed to vaccinate all airplane personnel working on international flights and at ports of call in Peru, the Canal Zone, Central America, and the Caribbean, and to require all passengers to fill out a Certificate of Origin to further monitor possible risks of introduction. The Rockefeller Institute of Medical Research and its Rio de Janeiro laboratory provided the vaccines free of charge to Pan American. ${ }^{41}$ A May 27, 1940 issue of Life featured images of the fumigation protocols of Pan American at Miami, with assurances to its readers that, "Not one infected person nor a single live mosquito has managed to get into the country past the Pan American Airways seaplane base at Miami. ${ }{ }^{42}$

By 1934, when the aforementioned seaplane base at Dinner Key opened for passenger service, Pan American controlled fifty-four percent of all air routes in Latin America. Rivals acquired by Pan American during the 1930s included Cubana de Aviación, Chilean Airways, Peruvian Airways, and Colombia’s Urabá, Medellín, and Central Airways, in addition to purchasing controlling stakes in

${ }^{40}$ T.H.D. Griffitts and J.J. Griffitts, "Mosquitoes Transported by Airplane: Staining Method Used in Determining Their Importation," Public Health Reports, Vol. 46, No. 47 (Nov. 20, 1931): 2775-2782.

41 "Preventing the Spread of Yellow Fever Through Air Traffic," Public Health Reports, Vol. 52, No. 31 (Jun. 30, 1937): 1027-1030.

42 "Yellow Fever Control: U.S. Health Service Watches Miami Clipper Port," Life, May 27, 1940, 41-42. 
SCADTA, NYRBA, and Compañia Mexicana de Aviación discussed earlier. Airmail represented roughly two-thirds of the traffic, but business travel continued to increase, as did leisure travel. U.S. corporations found that more efficient air travel reduced the need to maintain subsidiary branches of their operations in Latin America, as a business traveler could visit all the principal cities in a manner of weeks instead of months aboard an ocean steamer. ${ }^{43}$

Pan American's company travelogue film Flying the Lindbergh Trail (1937), complete with scenic tours of Cuba, Haiti, Puerto Rico, British Guiana, Brazil, and Argentina, and their exoticized "natives," began with scenes of the Dinner Key seaport, bustling with, "businessmen who find the aerial trade route swiftest [and] pleasure travelers in search of all the color and romance of far away places," aboard seaplanes, "larger than the ship in which Columbus first crossed the Atlantic. ${ }^{44}$ Also in 1937, in a comparative study of the American, European, and Australasian Mediterranean air routes for Geographical Review, Carl Hanns Pollog wrote that, "Miami is, of course, a center of first magnitude; like Athens and Bangkok, it belongs to that class of cities that, playing a rather insignificant

${ }^{43}$ Josephson, Empire of the Air, 88-89; Van Vleck, Empire of the Air, 71.

${ }^{44}$ Flying the Lindbergh Trail, produced and photographed by Palmer Miller and Curtis F. Nagel (New York: Pan American Airways, 1937), film. For much more on the links between tourism, films, and planes, see Rosalie Schwartz, Flying Down to Rio: Hollywood, Tourists, and Yankee Clippers (College Station, TX: Texas A\&M University Press, 2004); and on the construction of pleasure zones for U.S. tourists, see Dennis Merrill, Negotiating Paradise: U.S. Tourism and Empire in Twentieth-Century Latin America (Chapel Hill, NC: University of North Carolina Press, 2009). 
role in ground traffic, are extremely important for the air." 45 With Pan American's international routes and the domestic passenger service from the north established by Eastern Airlines in 1930 and National Airlines in 1934, no other city compared to Miami in more fully bridging the gap between the Americas. ${ }^{46}$

From 1928 until the interruption of services during World War II, the U.S. Post Office paid Pan American \$123 million in mail fees. The international airline conglomerate essentially operated as a subsidized extension of federal prerogatives with respect to the hemisphere. ${ }^{47}$ Congress commemorated the twenty-fifth anniversary of the Post Office airmail service in 1943, "in recognition of the part played by air mail in the development of the air transportation system which is making a large contribution to the war effort." ${ }^{48}$ The interests of state and capital underwrote Pan American as well as contributed to Miami's ascent as an air center of first magnitude. After Pearl Harbor, Miami again assumed the role of a military aerial training ground, but on an unprecedented scale. Facilities created to serve the burgeoning domestic and international commercial and airmail enterprises found new uses in wartime. After the war, with

${ }^{45}$ Carl Hanns Pollog, "Commercial Aviation in the American Mediterranean," Geographical Review, Vol. 27, No. 2 (Apr., 1937): 267.

${ }^{46}$ Aurora E. Davis, "The Development of the Major Commercial Airlines in Dade County, Florida: 1945-1970," Tequesta, Vol. 32 (1972): 5.

${ }^{47}$ Josephson, Empire of the Air, 216-217.

48 "Commemorating the Anniversary of the Inauguration of Air-Mail Service," United States House of Representatives, 78th Congress, 1st Session, Report No. 408, May 4. 1943; for more on the links between airmail and commercial air service, see F. Robert van der Linden, Airlines and Air Mail: The Post Office and the Birth of the Commercial Aviation Industry (Lexington, KY: University of Kentucky Press, 2002). 
commencement of civilian air travel, Miami renewed its vital role in the maintenance of airgemony. Cold War imperatives to fight communism required novel techniques of projected airpower, and challenges to U.S. airgemony manifested in equally novel ways.

\section{Cruising at Altitude, Experiencing Some Turbulence: From World War to Cold War Miami}

The first hints of preparedness for war came to Miami in 1939. EmbryRiddle, a defunct civilian flight training business from Cincinnati, reestablished itself on the County Causeway. By 1940, the school had 500 enrolled civilian flying students. Embry-Riddle also trained at least 2,000 British Royal Air Force pilots in Miami throughout the course of the war. But the civilian training schools like Embry-Riddle paled in comparison to the coming flood of military trainees. Undersecretary of War Robert Patterson saw in Miami Beach's massive hotel infrastructure a solution to the problem of constructing necessary barracks facilities to train for the war effort. By fall 1942, Miami and Miami Beach hotels housed 78,000 soldiers (Fg. 4.4). In addition, every manner of aerial training, from bombers to airships, filled the skies. The Navy expanded airport facilities in Opa-Locka originally built by Glenn Curtiss and built an airship station south of Miami in the agricultural outpost of Richmond. ${ }^{49}$

49 Gary R. Mormino, "Midas Returns: Miami Goes to War, 1941-1945," Tequesta, Vol. 57 (1997): 5-51; David Macfie, "Richmond Naval Air Station, 1942-1961" Tequesta, Vol. 37 (1977): 38-50; see also, Anthony D. Atwood, "A State of War: Florida from 1939 to 1945," (PhD diss., Florida International University, 2012). 


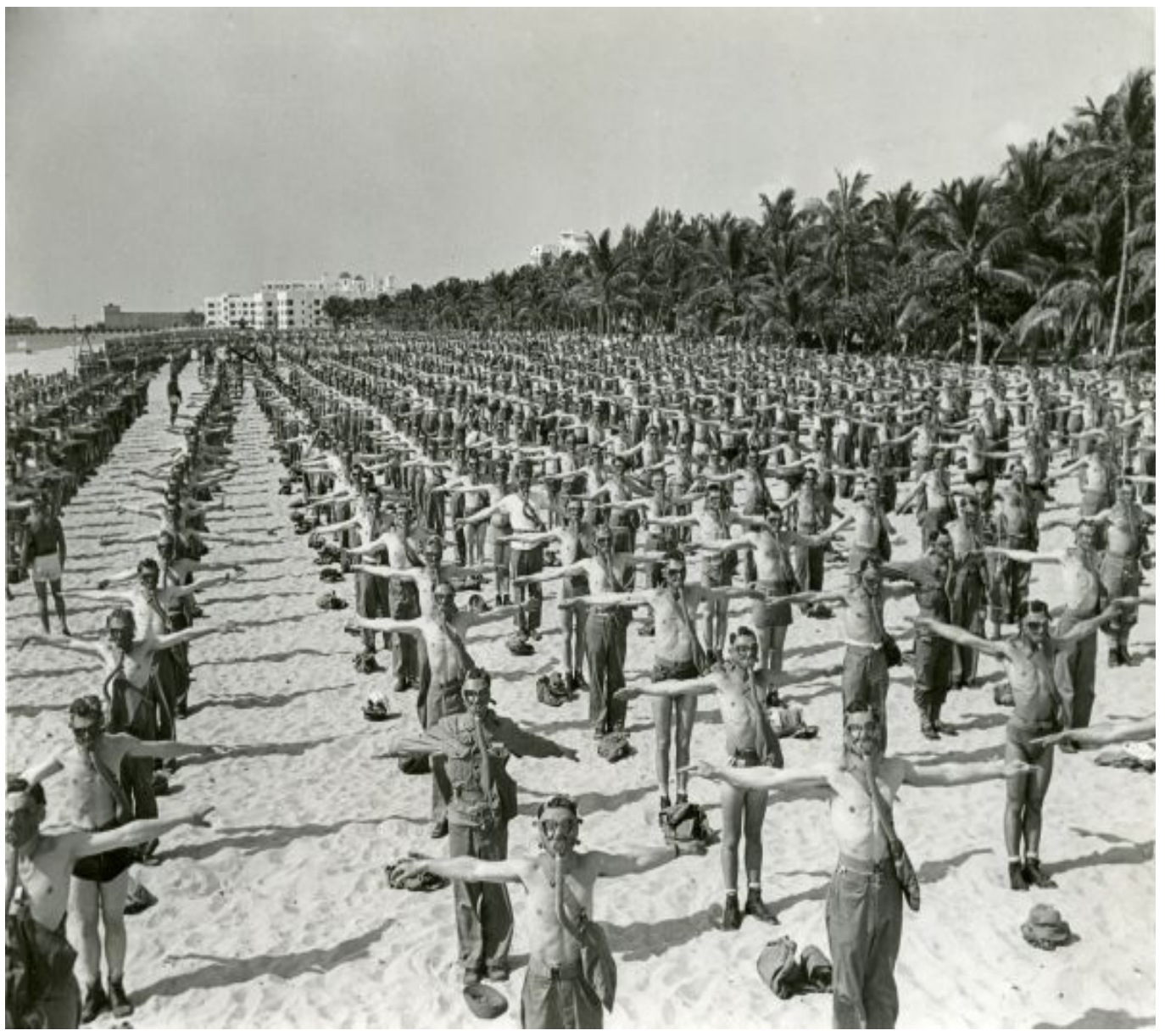

Figure 5 "Soldiers Performing Training Exercises on the Beach during WWII - Miami Beach, Florida," 1942-45, State Archives of Florida, Florida Memory.

The Army Air Force centralized all of its training of officers on Miami

Beach at the Army Air Force Officer Candidate School (OCS). The famous actor

Clark Gable registered for officer training, and he lent his media savvy to narrate a recruitment film for the OCS called Wings Up (1943), filmed entirely on location in Miami. The film began with a hypothetical nervous Army Air Force officer unable to perform his duties during a crisis. "Why did this man get the job?" Gable wondered, "Isn't there an X-Ray machine that can look into a man and say, 'He'll do.' Yes, there is such an X-Ray machine that looks into men's minds and hearts and souls, and finds them either adequate or wanting. It's called 
the Officer Candidate School of the Army Air Force, and it's situated at Miami Beach, Florida." 50

As Miami prepared for war by scanning for adequate hearts and minds, Pan American Airways, funded by the War Department, initiated in 1941 a massive Airport Development Program in Latin America. Fifty-one airports and six seaports in fifteen countries, along with critical telecommunication and utility service infrastructure, were either created or renovated as part of the war effort at a cost of $\$ 37$ million, all under the guise of commercial enterprise. The program employed somewhere between 55,000 to 125,000 local laborers, often working in remote jungle locations under harsh, unsanitary conditions. ${ }^{51}$ The War Department convinced neutral countries like Colombia to join the Allied cause through Lend-Lease provisions of airplanes, boats, and financial aid, on the condition that German members of the SCADTA airline be turned over for internment in the U.S. The threat of German pilots sympathetic to the Nazi regime flying near the critical Canal Zone required vigilance and acquiescence by any means necessary. Ecuador, Bolivia, and Peru likewise agreed to exchange Germans for aid. ${ }^{52}$

On the morning of January 11, 1943, an unannounced entourage arrived via train to Pan American's Dinner Key seaplane base to board the Dixie Clipper. President Franklin Roosevelt, en route to the Casablanca Conference in Morocco,

\footnotetext{
${ }^{50}$ Wings $U p$, produced by the First Motion Picture Unit, Army Air Forces (Washington, DC: Office of War Information, Bureau of Motion Pictures, 1943).

${ }^{51}$ Van Vleck, Empire of the Air, 84-87.

${ }^{52}$ Max Paul Friedman, Nazis and Good Neighbors, 113-115.
} 
boarded the plane, becoming the first sitting president in U.S. history to fly. Described by the pilot as a "good air sailor," Roosevelt traveled from Miami to Casablanca and back with stops in Trinidad and Brazil along Pan Am's established routes. ${ }^{53}$ It seemed natural and fitting that the first president to fly should do so from the city so integral to the establishment of U.S. airgemony aboard the wings of the federal government's chosen corporate partner. Post-war transitions from seaplanes to longer-range land planes for Pan Am spelled the end of Dinner Key as the busy international hub of its operations, and it turned over the airport to the city of Miami in 1948, where in 1954 the famed seaport became the home of Miami City Hall, still the site of city government today. ${ }^{54}$

Anticipating the post-war expansion of commercial aviation and the continued growth of U.S. airgemony, Juan Trippe told the National Foreign Trade Convention in 1943 that, "Man now stands on the threshold of the Age of Flight, the Air Age, when not just single nations or single continents, but the entire globe will become one neighborhood - when San Francisco and Shaghai, New York and Moscow, Miami and Capetown, will be figuratively just across the street.",55 Miami regained its rightful place as a major city in the coming global air neighborhood after the war. Pan American, Eastern Airlines, National Airlines, and Delta Airlines all dramatically expanded passenger services to and from

53 Tony Reichhardt, "The First Presidential Flight," Air \& Space Magazine, Jan. 18, 2013.

${ }^{54}$ Aurora E. Davis, "The Development of the Major Commercial Airlines in Dade County," 6-7.

${ }^{55}$ Speech reprinted as Juan T. Trippe, "Foreign Trade in the Air Age," Hispania, Vol. 29, No. 1 (Feb., 1946): 105. 
Miami in the post-war decade from 1945-1955. In 1954 alone, Eastern serviced nearly 2 million passengers at the expanded and newly renamed Miami International Airport (MIA) at NW 36th Street. For international traffic alone, in 1955 MIA serviced 783,351 passengers and processed 106,415,481 pounds of cargo as well as 3,588,970 pounds of mail. By 1960, the four major airlines employed 15,000 aviation industry personnel with an annual payroll of $\$ 75$ million, solidifying aviation as the major economic force in Miami. ${ }^{56}$ With cheaper fares and routinized service, multi-day air and hotel packages through Miami to points south regularly advertised in professional publications, further normalizing the means of international travel and increasing the consumer base. ${ }^{57}$

While more and more Americans and foreign travelers jetted through MIA, the city quietly embarked on a decades-long aerial engagement in the Cold War with a first stop in Guatemala. Codenamed LINCOLN, the Central Intelligence Agency clandestinely executed Operation PBSUCCESS from the Glenn Curtiss-planned Miami suburban airport of Opa-Locka during 1953-1954, in a building constructed for the Navy during World War II and intermittently used thereafter by the Marines and the Coast Guard. Guatemalan journalists critical of democratically-elected President Jacobo Arbenz flew to Miami on secret flights from Honduras and Mexico to help write and record the tapes of $L a$

${ }^{56}$ An International Trade Statistical Report on the Port of Miami, Florida \& Miami International Airport (Tallahassee, FL: Florida Development Commission, 1956): 61-62; Davis, 7-10.

${ }^{57}$ See, for instance, W.M. Moloney, "After Miami Beach - South America or the Caribbean?" American Bar Association Journal, Vol. 45, No. 5 (May, 1959): 492494. 
voz de liberación (Voice of Liberation), the disinformation radio programs broadcasted to Guatemala from radio towers in Honduras. The airdropped propaganda leaflets that accompanied the broadcast also originated in Opa-Locka. Opa-Locka was the nerve center of the operation, in coordination with headquarters in Langley, Virginia, and several key CIA participants, including Tracy Barnes, E. Howard Hunt, and Richard Bissell, gained glowing reputations from the operation to secure future leadership roles in the Bay of Pigs planning, originally modeled as an exact replica of PBSUCCESS ${ }^{58}$ The political vacuum left behind from the CIA's successful coup against Arbenz resulted in over three decades of civil war and violence that claimed the lives of over 200,000 Guatemalans. ${ }^{59}$

Miami's clandestine air service to the Cold War reached new heights in the aftermath of the Cuban Revolution in 1959. The Bay of Pigs invasion and the Missile Crisis sequentially raised the stakes involved in the struggle for continued

${ }^{58}$ Piero Gleijeses, Shattered Hope: The Guatemalan Revolution and the United States, 1944-1954 (Princeton, NJ: Princeton University Press, 1992), 288-292; Richard H. Immerman, The CIA in Guatemala: The Foreign Policy of Intervention (Austin, TX: University of Texas Press, 1982), 138-141; Nicholas Cullather, Operation PBSUCCESS: The United States and Guatemala, 1952-1954 (Washington, DC: Central Intelligence Agency, 1994), 30, sanitized and declassified by CIA Historical Review Program, 1997. Opa-Locka is sanitized as the location of the operation in the CIA history, despite the fact that it quotes Gleijeses and Immerman, where the information is readily available; see also, Foreign Relations of the United States, 1952-1954, Guatemala, edited by Susan Holly (Washington, DC: Government Printing Office, 2003); Evan Thomas, "“You Can Own the World'," Washington Post, Oct. 22, 1995; Alfonso Chardy, "Opa-Locka Field Was Once The Site of Secret CIA Base," Miami Herald, Apr. 20, 2013.

${ }^{59}$ For much more on the context and aftermath of PBSUCCESS from a Guatemalan perspective see Greg Grandin, The Blood of Guatemala: A History of Race and Nation (Durham, NC: Duke University Press, 2000). 
U.S. airgemony. Complicated in their respective details and deeply personal to those who lived through them, what follows, in the interest of space, can only be a cursory and selective overview of events that consumed years for scholars and participants alike.

Planning for an anti-Castro program, project codename JMARC later changed to JMATE, began under President Dwight Eisenhower on March 16, 1960. From initial planning through post-invasion analysis, air power involving the CIA, the Joint Chiefs of Staff, and the various military branches figured most prominently. The plan required aircrafts for infiltration, propaganda, and supply drops to dissident groups within Cuba, as well as for transporting bodies and equipment to training sites outside the continental U.S. To maintain the illusion of non-involvement, the CIA conducted recruitment efforts in Miami at the Forward Operation Base, codenamed JMASH. The targeted recruits in Miami constituted former members of the Cuban Air Force, personnel of the Cubana de Aviación Airline, private pilots, and former armed service personnel. By May 1960, a recruitment office headed by CIA and Navy officers operated out of a motel in Coral Gables. Various air fields provided cover for the transport of Cuban recruits to the chosen mission base in Retalhuleu, Guatemala, including at Opa-Locka, Fort Lauderdale, and the old Tamiami airport, all under the cover of normal passenger and cargo manifests to avoid detection from Cuba's Air Defense Command radar. On February 15, 1961, 75,000 leaflets asking teachers to support student strikes were made available from Miami, dropped in the following weeks over the Villanueva University campus in Havana. A crucial part of the cover plan 
for the actual air attack on April 15, 1961 involved Cuban pilots flying from Guatemala to Cuba, then traveling back to Miami International Airport while sending out distress signals that they were defecting from Cuba and requesting asylum, a plan more or less successfully executed but complicated by an actual defection that landed a day earlier in Jacksonville. Other planes involved in the air attack flew below 25 feet as they exited Cuban air space to avoid radar, and then climbed to safer heights before approaching Miami. ${ }^{60}$ The preceding summary only briefly highlights Miami's role in the planning and execution of the operation as described in the CIA approved history and leaves aside the failed land invasion that followed the successful air attacks on Cuban air force facilities. ${ }^{61}$ The foregoing details, though, make clear that any attempt to assess the Bay of Pigs invasion necessitates consideration of Miami as a fundamental site of planning and operation in the attack.

Continued counter-revolutionary attacks on Cuba and fears of another Bay of Pigs invasion encouraged Fidel Castro's acceptance of a Soviet offer to install

${ }^{60}$ Jack B. Pfeiffer, Official History of the Bay of Pigs Operation, Vol. 1, Air Operations, March 1960 - April 1961, Part 1 (Langley, VA: Central Intelligence Agency, 1979, sanitized and approved for release July 25, 2011), 59, 84, 126, 132, 138, 148, 151, 153-155, 164, 173, 196-197, 231-236, 253-256, 273, 297.

${ }^{61}$ For much more, see Piero Gleijeses, "Ships in the Night: The CIA, the White House and the Bay of Pigs," Journal of Latin American Studies, Vol. 27, No. 1 (Feb. 1995): 1-42; Peter Kornbluh, Bay of Pigs Declassified: The Secret CIA Report on the Invasion of Cuba (New York: New Press, 1998); Steve Hach, Cold War in South Florida: Historical Resource Study (Atlanta, GA: Department of Interior - National Parks Service, 2004); and the other volumes of Jack B. Pfeiffer's official history. 
the nuclear missiles in September, first suggested in the spring of $1962 .{ }^{62}$ Once U2 spy planes discovered the missile installation sites in October, south Florida and Miami armed for Armageddon. The U.S. Army installed HAWK and Nike Hercules missile battalions in several locations around Miami, but never with attached nuclear warheads (Fg. 4.5) ${ }^{63}$ Premier Nikita Khrushchev and President Kennedy agreed to mutually withdraw nuclear weapons from Cuba and Turkey respectively without including Castro in the negotiations. Feeling double-crossed, the result of the crisis severely limited Soviet influence in Cuba and set Castro on a decidedly independent path in his international policies. ${ }^{64}$ The brink of World War III challenged outright Miami's secure place as the projected center of U.S. airgemony. Other instances of counter-airgemony, however, primarily involved non-state actors aboard commercial planes.

${ }^{62}$ A view of the events that led to the crisis from inside the Cuban intelligence community is presented in Domingo Amuchastegui, "Cuban Intelligence and the October Crisis," Intelligence and National Security, Vol. 13, No. 3 (1998): 88119.

${ }^{63}$ Steve Hach, Cold War in South Florida, 23; see also, Robert Kipp, Lynn Peake, and Herman Wolk, Strategic Air Command Operations in the Cuban Missile Crisis of 1962, Historical Study No. 90, Vol. 1 (Washington, DC: United States Air Force, 1963).

${ }^{64}$ James G. Blight and Philip Brenner, Sad and Luminous Days: Cuba's Struggle with the Superpowers after the Missile Crisis (Lanham, MD: Rowman and Littlefield, 2007); see also, Philip Nash, The Other Missiles of October: Eisenhower, Kennedy, and the Jupiters, 1957-1963 (Chapel Hill: University of North Carolina Press, 1997). 


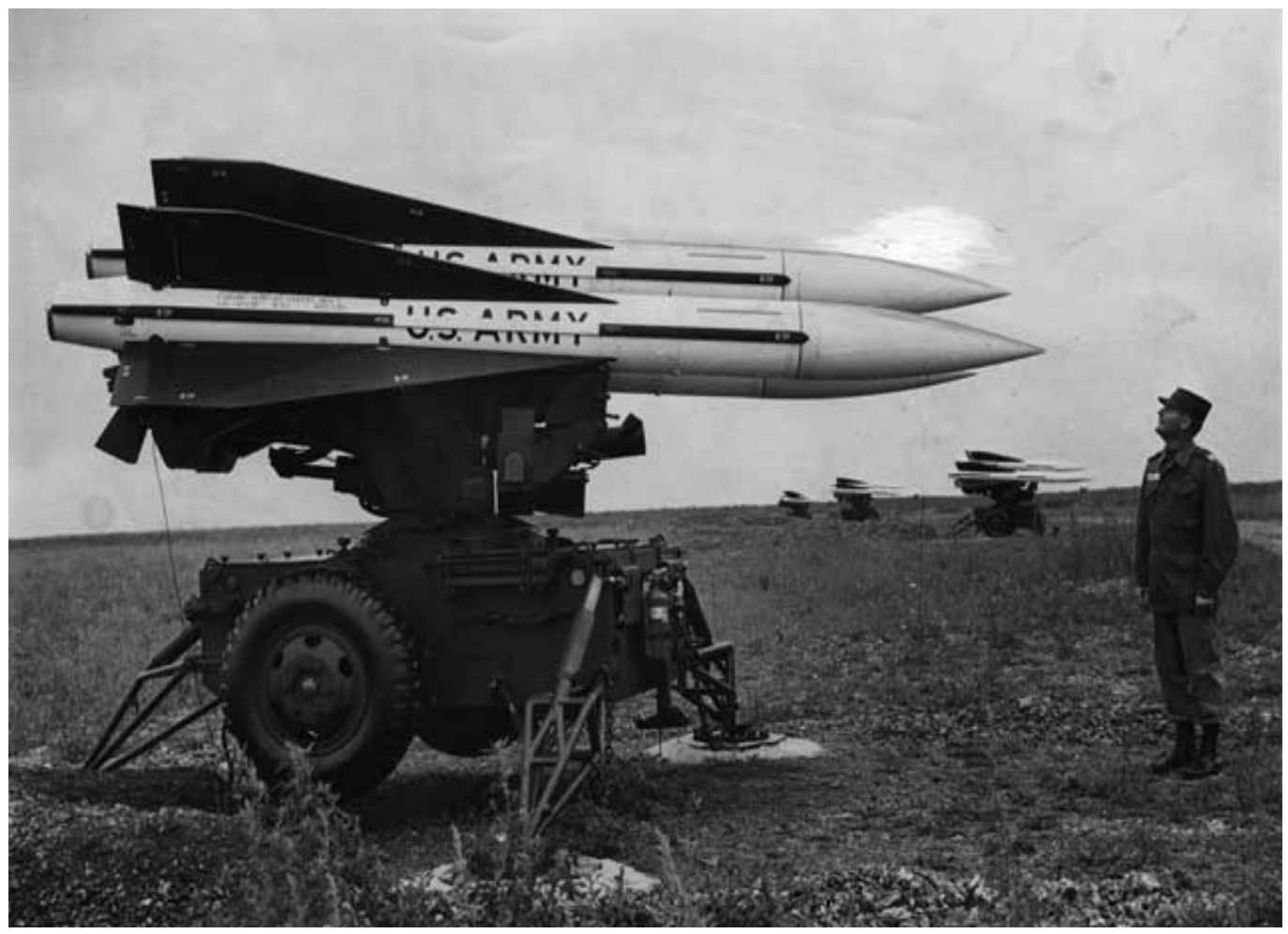

Figure 6 "A Soldier Sizes Up Hawk Missiles at the Base in Everglades National Park, March 1963," Miami News Collection, HistoryMiami, 1994-370-885.

Florida's coasts had long sheltered the proliferation of pirates that attacked Spanish vessels, as we saw in chapter one. After 1960, the skies above Miami became the contested space of a new breed of pirates. Air piracy plagued commercial airlines in periodically intensive waves from the 1960 s through the 1980s. The majority of air pirates in the 1960s were politically left-leaning Americans, who seized control of commercial planes and redirected the flight patterns to Havana. ${ }^{65}$ From 1961 to 1983,225 attempted hijackings of American commercial planes occurred, with 115 successes. At least seventy-five percent of

${ }^{65}$ Seymour W. Wurfel, “Aircraft Piracy - Crime or Fun?” William \& Mary Law Review, Vol. 10, Issue 4 (1969): 820-873. 
those hijackings rerouted to Cuba. ${ }^{66}$ Air piracy laws in the United States and stiff penalties of twenty years in prison did little to dissuade potential pirates, but the regularity of diverted planes to Havana became an embarrassment for Castro. ${ }^{67}$ Secret agreements between Castro and President Richard Nixon, worked through the U.S. Interest Section at the Swiss Embassy in Havana, established protocols for the prompt return of passengers, while the Federal Aviation Administration devised profiling procedures, global airport security screenings, and the use of air marshals ${ }^{68}$ By the 1980s, pirates en route to Havana more often than not were disaffected recent immigrants from Cuba who came to Miami during the Mariel boatlifts. $^{69}$

The weaponization of commercial planes as enacted on September 11, 2001, irrevocably shattered the pattern of air piracy established in struggles for airgemony over the Florida Straits. More relevant to the analysis of this chapter, fourteen of the nineteen identified terrorists on 9/11 lived in Greater Miami on the eve of their planned attack, and several received civilian flight training in south Florida. Ziad Jarrah, one of the hijackers of United Airlines Flight 93 that crashed

\footnotetext{
${ }^{66}$ Barry Bearak, "Hijackers - They're Still Flying High," Los Angeles Times, Aug. 4, 1983.

${ }^{67}$ Jorge I. Domínguez, To Make the World Safe for Revolution: Cuba's Foreign Policy (Cambridge, MA: Harvard University Press, 2009), 122.

${ }^{68}$ Timothy M. Ravich, "Is Airline Passenger Profiling Necessary?" University of Miami Law Review, Vol. 62 (Oct., 2007): 1-57; William M. LeoGrande and Peter Kornbluh, Back Channel to Cuba: The Hidden History of Negotiations Between Washington and Havana (Chapel Hill, NC: University of North Carolina Press, 2015), 119-154.

${ }^{69}$ Bearak, "Hijackers - They’re Still Flying High."
} 
in Pennsylvania, took flight simulator lessons on the grounds of Miami International Airport at Aeroservice Aviation in December 2000 and January 2001. Jarrah and several others purchased their plane tickets to Boston, New York, and Baltimore and flew from Fort Lauderdale, Miami, and Palm Beach. The hijackers chose South Florida as the site of operations for the attack because of the prevalence of quality civilian aviation training facilities. ${ }^{70}$

\section{Baggage Claim}

The Curtiss Flying School began innocently enough as an answered request to encourage a love of flying for Miamians. The growth of military and commercial aviation that followed Curtiss worked to position Miami at the forefront in the projection and security of U.S. airpower, in what I have called airgemony. Struggles to maintain airgemony took many forms, from colluding state and capital interests in search of airmail monopolies to clandestine coup operations, nuclear standoffs, and pirates of the air. Throughout peaceful times, World Wars, and a long Cold War, Miami's aviation infrastructure grew in mutual association with imperial objectives throughout the Americas and beyond. The legacy of civilian flight training, the impetus for Miami’s aerial ascent, tragically left open exploitable space for unprecedented strategies of counterairgemony in the form of the $9 / 11$ attacks.

70 "Statement for the Record, FBI Director Robert S. Mueller, III," Sep. 26, 2002, at Joint Intelligence Committee Inquiry, http://fas.org/irp/congress/2002_hr/092602mueller.html; Andres Viglucci and Manny Garcia, "Hijack Plotters Used S. Florida as a Cradle for Conspiracy," Miami Herald, Sep. 15, 2001. 
Undaunted, Miami continues to grow as a national and global leader of aviation. As of 2014, Miami International Airport ranks first among U.S. airports in international freight, second in international passengers, and third in total cargo, a testament to the now-defunct Pan American Airways and Eastern Airlines. One hundred different airlines now fly to and from Miami to 147 nonstop destinations. One in four Miami jobs relate directly or indirectly to MIA, and aviation contributes over $\$ 32$ billion annually to the local economy. ${ }^{71}$

The projection of U.S. airgemony from Miami continues in an altered form with the move in 1997 of the United States Southern Command (SOUTHCOM) from Panama to Miami, in facilities located just west of MIA in the suburb of Doral. Overseeing all military operations and aid provisioning in Latin America and the Caribbean, the responsibilities of SOUTHCOM at its Miami headquarters included the 2004 U.S. Marine occupation of Haiti and the non-intervention and explicit recognition of a coup government in Honduras in 2009, occurring while the head of SOUTHCOM enjoyed a cozy existence in a Coral Gables Spanish Revival mansion on the taxpayer's dime. ${ }^{72}$

71 "Miami International Airport, U.S. and World Airport Rankings, Passengers and Flights," (Miami, FL: Miami-Dade Aviation Department - Marketing Division, 2015).

72 David S. Cloud, “Top Officers' Quarters are Their Castles," Los Angeles Times, Jul. 21, 2013; Dana Frank, "In Honduras, a Mess Made in the U.S.," New York Times, Jan. 26, 2012; Vanessa Buschschulter, "The Long History of Trouble Ties Between Haiti and the U.S.," BBC News, Jan. 16, 2010. 


\section{EPILOGUE}

\section{Return of the Gaze: The Imperial City Beckons its Subjects}

Without concerted attention to the material addressed in the preceding chapters, explanations fail to fully consider how Miami became a global city and the capital of Latin America. This dissertation argues that Miami's Hispanicization and globalization after 1959 in fact realized a vision first proposed by the city's founding matriarch and elaborated by successive generations of civic and business leaders. Contested colonial settlement, a constructed tropical environment, a predominantly Spanish architectural aesthetic, and an imperial aviation infrastructure made the city imminently familiar, appealing, and within reach to later generations of exiles and migrants. Celebrated today as multilingual and multicultural, Miami’s colorful mask of diversity conceals the bare essence of speculation, accumulation, and attendant inequality sustaining and expanding U.S.-led global capitalism; the same forces at work over the course of the city's history. Capital flight to Miami from political and economic instability elsewhere represents not a pursuit of democracy and freedom but a return to the safety and security of empire.

For years, bureaucratic, journalistic, and scholarly analyses of Cuban migration to Miami after 1959 relied either implicitly or explicitly on portraying the city on the eve of the Cuban Revolution as a dwindling tourist town. The idea that the city exploded with diversity after the Revolution contributed, in various ways, to a perception of Cubans as model minorities and as driving forces of 
change in the city. ${ }^{1}$ But more nuanced approaches to Cubans in Miami centered

on the violent tactics that helped consolidate local political power, the connections

between Cuban migrations and imperatives of the U.S. national security state, the

global capitalist forces shaping the city parallel to Cuban migration, as well as the

ethnic conflicts engendered between privileged Cuban migrants and

underprivileged and marginalized resident black Americans. ${ }^{2}$ More recently,

${ }^{1}$ For a bureaucratic version, see former Director of the Cuban Refugee Program Welfare Administration John F. Thomas, "Cuban Refugees in the United States," International Migration Review, Vol. 2 (Spr., 1967): 46-57; scholarly versions include the essays in Cuban Exiles in the United States, edited by Carlos E. Cortés (New York: Arno Press, Inc., 1980); Raymond A. Mohl, "Changing Economic Patterns in the Miami Metropolitan Area, 1940-1980," Tequesta, Vol. 42 (1982): 63-73; Barry B. Levine, "The Capital of Latin America," Wilson Quarterly, Vol. 9, No. 5 (Win., 1985): 46-69; Saskia Sassen and Alejandro Portes, "Miami: A New Global City?" Contemporary Sociology, Vol. 22, No. 4 (Jul., 1993): 471477; Alejandro Portes and Alex Stepick, City On the Edge: The Transformation of Miami (Berkeley, CA: University of California Press, 1993); John Beverley and David Houston, "Notes on Miami," boundary 2, Vol. 23, No. 2 (Sum., 1996): 1946; Maria Cristina Garcia, Havana USA: Cubans and Cuban Americans in South Florida, 1959-1994 (Berkeley, CA: University of California Press, 1997); the construction of Cubans as modeled minorities is explored in Jeanine Navarrete, "From Refugees to Model Minorities: Cuban-Americans and the Media in Miami, 1960-1970" (PhD diss., University of North Carolina-Chapel Hill, 2013); for a representative journalistic version, see Cathy Booth, "Miami: the Capital of Latin America," Time, Jun. 24, 2001.

${ }^{2}$ Lourdes Arguelles, "Cuban Miami: The Roots, Development, and Everyday Life of Emigré Enclave in the U.S. National Security State," Contemporary Marxism, No. 5 (Sum., 1982): 27-43; Christopher L. Warren, John F. Stack, and John G. Corbett, "Minority Mobilization in an International City: Rivalry and Conflict in Miami," PS, Vol. 19, No. 3 (Sum., 1986): 626-634; Carlos A. Forment, "Political Practice and the Rise of an Ethnic Enclave: The Cuban American Case, 19591979," Theory and Society, Vol. 18, No. 1 (Jan., 1989): 47-81; within the span of a decade, Raymond A. Mohl's tone regarding Cuban migrants became much more critical compared to the article cited in footnote 1, with the more critical stance apparent in Mohl, "On the Edge: Blacks and Hispanics in Metropolitan Miami since 1959," Florida Historical Quarterly, Vol. 69 (Jul., 1990): 37-56; Ramón Grosfoguel, "World Cities in the Caribbean: The Rise of Miami and San Juan," Review (Fernand Braudel Center), Vol. 17, No. 3 (Sum., 1994): 351-381; María 
scholarship has filled in the gaps to explore the history Cubans in Miami prior to 1959, the significance of other ethnic migrants to Miami before the Cuban Revolution, civil rights advances gained by black Miamians by way of Latin American tourism to the city, political deployments of children in consolidating power in Miami and Havana, transnational musical networks linking Havana, Miami, and New York, and transnational solidarity networks forged between generations of leftists in the U.S. and their exiled counterparts in Miami and elsewhere in the 1930 s and 1950 s. $^{3}$

de los Angeles Torres, In the Land of Mirrors: Cuban Exile Politics in the United States (Ann Arbor, MI: The University of Michigan Press, 1999); This Land Is Our Land: Immigrants And Power In Miami, edited by Alex Stepick, Guillermo J. Grenier, and Max Castro (Berkeley, CA: University of California Press, 2003); Miguel A. de la Torre, La Lucha for Cuba: Religion and Politics on the Streets of Miami (Berkeley, CA: University of California Press, 2003); see also, Guillermo J. Grenier and Max Castro, "Blacks and Cubans in Miami: The Negative Consequences of the Cuban Enclave on Ethnic Relations," in Governing American Cities: Inter-Ethnic Coalitions, Competition, and Conflict, edited by Michael Jones-Correa (New York: Russel Sage Foundation, 2001), 137-157.

${ }^{3}$ Paul Harper, "Cuba Connections: Key West, Tampa, and Miami, 1870 to 1945," Journal of Decorative and Propaganda Arts, Vol. 22 (1996): 278-291; Francis J. Sicius, "The Miami-Havana Connection: The First Seventy-Five Years," Tequesta, Vol. 58 (1998): 4-45; Louis A. Pérez Jr., "Between Encounter and Experience: Florida in the Cuban Imagination," Florida Historical Quarterly, Vol. 82, No. 2 (Fall, 2003): 170-190; Melanie Shell-Weiss, Coming to Miami: A Social History (Gainesvile, FL: University of Florida Press, 2009); Jorge Duany, Blurred Borders: Transnational Migration between the Hispanic Caribbean and the United States (Chapel Hill, NC: University of North Carolina Press, 2011); Chanelle N. Rose, "Tourism and the Hispanicization of Race in Jim Crow Miami, 1945-1965," Journal of Social History, Vol. 45, No. 3 (Spr., 2012): 735-756; Rose, The Struggle for Black Freedom in Miami: Civil Rights and America's Tourists Paradise, 1896-1968 (Baton Rouge, LA: Louisiana State University Press, 2014), Ch. 6; Anita Casavantes Bradford, The Revolution is for the Children: The Politics of Childhood in Havana and Miami, 1959-1962 (Chapel Hill, NC: University of North Carolina Press, 2014); Christina D. Abreu, Rhythms of Race: Cuban Musicians and the Making of Latino New York City and Miami, 1940-1960 (Chapel Hill, NC: University of North Carolina Press, 2015); John A. 
Informed to varying degrees by all of the above, this Epilogue argues that certain privileged Cuban and other elite Latin Americans - though a small but significant segment of the migrant population - managed to reconstitute themselves in Miami as imperial subjects both before and after the Revolution. The period prior to 1959 saw exiled Cubans in Miami voicing alternatives to political realities on the island in a manner similar to previous generations in New York, Tampa, and Key West. After 1959, those possibilities narrowed as anticommunist terrorists, cocaine cowboys, and rich expats alike thrived in the imperial city. Miami offered, and continues to offer, a safety valve for Latin America's neoliberal elite when leftward trending regimes threatened their livelihoods and accumulated property at home. In the comfort of familiar architecture, under the shade of familiar tropical vegetation, and traveling in safe passage on the wings of empire, Miami protects its subjects from the uncertainties of a postcolonial existence. Despite its prolonged local usefulness, however, an anti-communist, pro-capitalist political identity has begun to lose its mobilizing power, as the lure of renewed profits in Cuba proves too tempting to ignore. Rather than preparing for a post-Castro Cuba, it appears Miami is bracing for a post-exile political economy that will diminish the political power of anticommunism and encourage renewed capitalist engagement with Cuba. Once the privileged recipients of imperial benevolence, those eager to remain within the confines of the imperial city will have to recalibrated strategies.

Gronbeck-Tedesco, Cuba, the United States, and Cultures of the Transnational Left, 1930-1975 (New York: Cambridge University Press, 2015). 


\section{Pan Americanism and the Latin American Presence in Miami before 1959}

As addressed in earlier chapters, Cuban pilots and architectural builders trained and worked in Miami in the 1910s and 1920s. George Merrick intended his University of Miami in Coral Gables, founded in 1925, to be "the great PanAmerican seat of learning of the South. ${ }^{, 4}$ Frank Shutts, founder of the Miami Herald, foresaw at the cornerstone laying ceremony that the university would "attract students from Central and South American countries."5 Merrick's lawyer wrote to him in December 1926 to highlight a lecture he heard at the university by Peruvian Víctor Andrés Belaúnde regarding Pan-Americanism, the Monroe Doctrine, and the need for more North-South cooperation. ${ }^{6}$ Belaúnde later served on behalf of Peru at the United Nations. His nephew and future two-time president of Peru, Fernando Belaúnde Terry, attended the architectural school at the University of Miami during his uncle's brief tenure there. In a letter to Cuban General Alberto Herrera in 1928, George Merrick explained that the university "has for one of its chief aims, giving facilities to educational and business intercourse between America and Latin American countries."7 Two Peruvian exchange students on scholarship at the University of Miami in 1932, brothers

4 “Coral Gables Facts,” (Miami: Coral Gables Sales Corporation, Apr. 1927), 16.

5 "Lay Cornerstone of Miami University," New York Times, Feb. 5, 1926, 6.

${ }^{6}$ Letter from Clifford Benson to George Merrick, Dec. 18, 1926, Folder 1958003, 1-3, in George Merrick Papers, Box 1, 1920s-30s, at Charlton W. Tebeau Research Library, HistoryMiami.

${ }^{7}$ Letter from George Merrick to General Herrera, Aug. 15, 1928, Folder 1958003, 1-3, in George Merrick Papers, Box 1, 1920s-30s, at Charlton W. Tebeau Research Library, HistoryMiami. 
Alfonso and Luis Montero, received an honorary welcome from the Miami Beach Committee of $100 .{ }^{8}$ In explicit contrast to the welcoming attitude of Miami's white elite toward Hispanic students at the university, the first black student was finally admitted three decades later in 1961 after years of agitation from black civil rights organizations. ${ }^{9}$

Miami annually celebrated Pan American Day beginning in 1931, a reflection of the city's desire to present itself as a friend to Latin America and encouraged by Pan American Airways and its daily flights to and from points south. For the 1934 celebration, a pageant titled "Cuba Libre" acted out a condensed history of the island. Large groups of Miami school children led a parade for the event, representing all nations of the Pan American Union. Later announced events related to the celebration included an International Salon de Arte on display at the downtown Hacylon Hotel, featuring antiques from Latin American countries. ${ }^{10}$ The Pan American League in Miami, led by Colombian Juan N. Calvo, actively promoted Pan Americanism locally and around the country. Hispania credited the league with establishing high school student clubs in seventy-five cities around the country to encourage the teaching of Latin

\footnotetext{
${ }^{8}$ Newsclipping from Miami Daily News, Feb. 12, 1932, in Committee of One Hundred Scrapbook, 1931-32, 2007-408, Box 5, at Charlton W. Tebeau Research Library, HistoryMiami.

${ }^{9}$ Chanelle N. Rose, "Tourism and the Hispanicization of Race in Jim Crow Miami, 1945-1965," 747.

${ }^{10}$ Joshua Hochstein, “Announcements," Hispania, Vol. 17, No. 2 (May, 1934): 209-210.
} 
American history. ${ }^{11}$ A June 10, 1934 edition of the Miami Daily News, writing from a hypothetical 1950 future Miami, featured pictures of dense skyscrapers along Biscayne Bay, and highlighted the significance of a hypothetical resident "Latin American colony" that increased the city's commercial and cultural relations with the hemisphere. ${ }^{12}$

Cultural exchanges linking Miami and Havana included football games between the University of Havana and the University of Miami, with the former arriving via Pan American Airways mail planes (Fg. E.1). The inaugural CubaMiami Beach tennis matches began in $1929 .{ }^{13}$

${ }^{11}$ A. Curtis Wilgas, "The Teaching of Latin-American History in Secondary Schools," Hispania, Vol. 23, No. 1 (Feb., 1940): 66.

12 "Miami of the Future Edition," Miami Daily News, Jun. 10, 1934.

${ }^{13}$ Newsclipping from New York Evening Post, Feb. 16, 1929, in Clayton Sedwick Cooper Scrapbook, Fall 1928-Spring 1929, Committee of 100 Scrapbooks, 192529, 2007-408, Box 1, at Charlton W. Tebeau Research Library, HistoryMiami. 


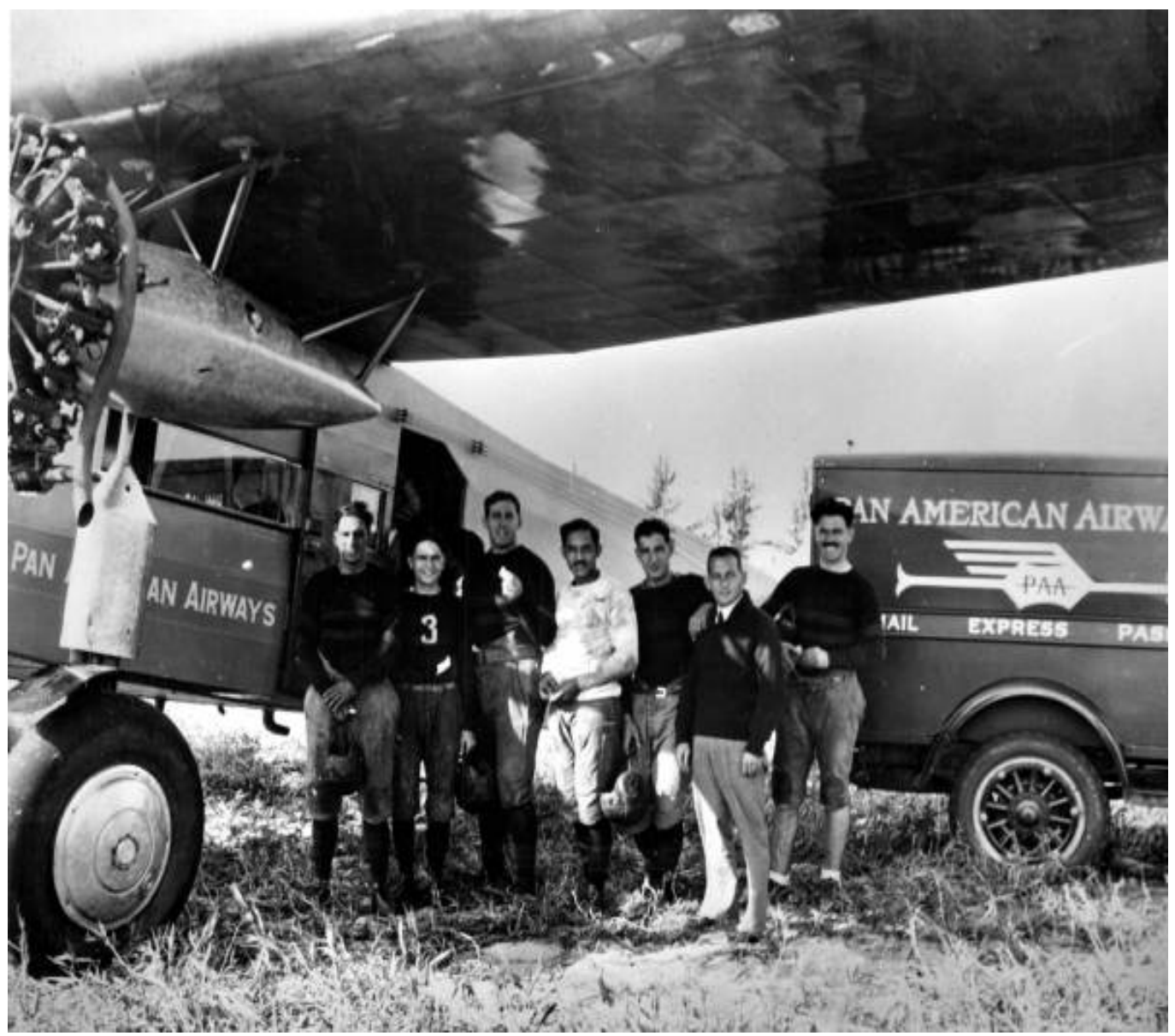

Figure E.1 "Cuban Football Team - Miami, Florida," 1928, State Archives of Florida, Florida Memory.

By 1933, Miami became for the first time the hotbed of exilic Cuban politics, displacing previous exile destinations in New York, Tampa, and Key West. After Gerardo Machado announced he would indefinitely maintain his presidency beyond his scheduled term of office, ex-President General Mario Menocal led one faction against Machado from his new residence on Miami Beach. A second, more radical faction, the student directorate of the University of Havana (DEU), also maintained its opposition from Miami. Both Menocal's faction and the student group, led by a young Carlos Prío Socorrás, sent out communiqués and letters of discontent with Machado and the mediation of U.S. Ambassador Sumner Welles, and both advocated for the end of the Platt Amendment that 
authorized U.S. intervention on the island. A young officers coup finally overthrew Machado in August 1933, led by Fulgencio Batista. Most of the refugees in Miami left to rejoin the new government, but not before violent demonstrations in downtown erupted upon the arrival of Machado's wife to Miami. Machado escaped to Nassau after the coup and eventually settled in Miami Beach where he died in 1938, becoming the first of several notable Cubans buried at Woodlawn Cemetery on SW 8th Street. ${ }^{14}$ Regardless of political orientation, the imperial city offered protection to whomever sought it.

Pan American's renewed air services after World War II brought Cubans to Miami as tourists by the thousands throughout the 1940s and 1950s, ranging from 40,000 to 50,000 travelers annually. Because of import duties on American goods to the island, shopping in Miami developed into a $\$ 70$ million annual revenue stream for the city by the $1950 \mathrm{~s} .{ }^{15}$ White and Afro-Cuban musicians regularly performed in segregated Colored Town and on Miami Beach during winter seasons throughout the post-war era. Famous entertainers and musicians on the local circuit included Desi Arnaz Jr., Miguelito Valdéz, Cugat, and José

\footnotetext{
14 "Rebels in Florida Hold Back," New York Times, Jun. 23, 1933, 7; "Menocal Assails Our Cuba Policy," New York Times, Jul. 5, 1933, 13; "Havana Students Scorn Mediation: Exile Group in Miami Says It Won't Deal with 'Executioners and Assassins'," New York Times, Jul. 15, 1933, N2; "Florida Playground Merrymaking Mecca," Miami Herald, Jan. 28, 1934; Francis J. Sicius, "The Miami-Havana Connection: The First Seventy-Five Years," 18-25; Hugh Thomas, Cuba: The Pursuit of Freedom (New York: Harper \& Row, 1971), 610, 671, 679, 696, 708.

${ }^{15}$ Louis A. Pérez Jr., "Between Encounter and Experience: Florida in the Cuban Imagination," 180, 184.
} 
Curbelo. ${ }^{16}$ Fidel Castro's first of three Miami visits came in October 1948 on the occasion of his honeymoon with his first wife, Mirta Díaz-Balart. The couple then met Mirta's brother Rafael and his wife Hilda in New York before driving back down U.S. 1 in Castro's newly purchased Lincoln Continental. ${ }^{17}$ Fidel, like so many upwardly mobile Cubans and elite Americans, experienced in Miami a place to enjoy the pleasures of empire. No small wonder, then, that those same pleasures later received his undying opposition.

Castro's most significant trip to Miami occurred in November 1955 after being released from prison following the attack on the Moncada army barracks on July 26, 1953. He spoke at the Cuban-owned Teatro Flagler in downtown Miami to secure funds for his expeditionary force against Fulgencio Batista's dictatorship (Fg. E.2). Ex-President Carlos Prío, who had come to Miami as a young student rebel in the 1930s, provided some of the funds during the Miami trip for Castro. Castro traveled from Miami to Mexico to organize his revolutionary force. In 1957, while a guerrilla war waged in the Sierra Maestra mountains, at least seven exiled political groups in Miami formed a Junta of National Liberation. A restoration of the Cuban Constitution of 1940, higher wages, and immediate elections factored among the agreed upon demands of the exiled junta, signing what became known as the Miami Pact. Castro later wrote to the junta denouncing the pact for its lack of language regarding foreign intervention, among other omissions. Disagreements about who should become the provisional president

${ }^{16}$ Christina D. Abreu, Rhythms of Race, 196.

${ }^{17}$ Alfonso Chardy and Luisa Yanez, "Fidel Castro Once Used Miami as Haven, Revolutionary Springboard," Miami Herald, Jul. 25, 2008. 
following the overthrow of Batista dissolved the multi-party alliance by 1958 , and the 26th of July Movement's victory the following year sealed the fate of a unified revolutionary government under Castro. ${ }^{18}$ Miami's availability to host foreign political movements of various persuasions typified its imperial dimensions. Whatever chaos and disorder existed on the island, Cubans continued to find safety and freedom of expression in the imperial city.

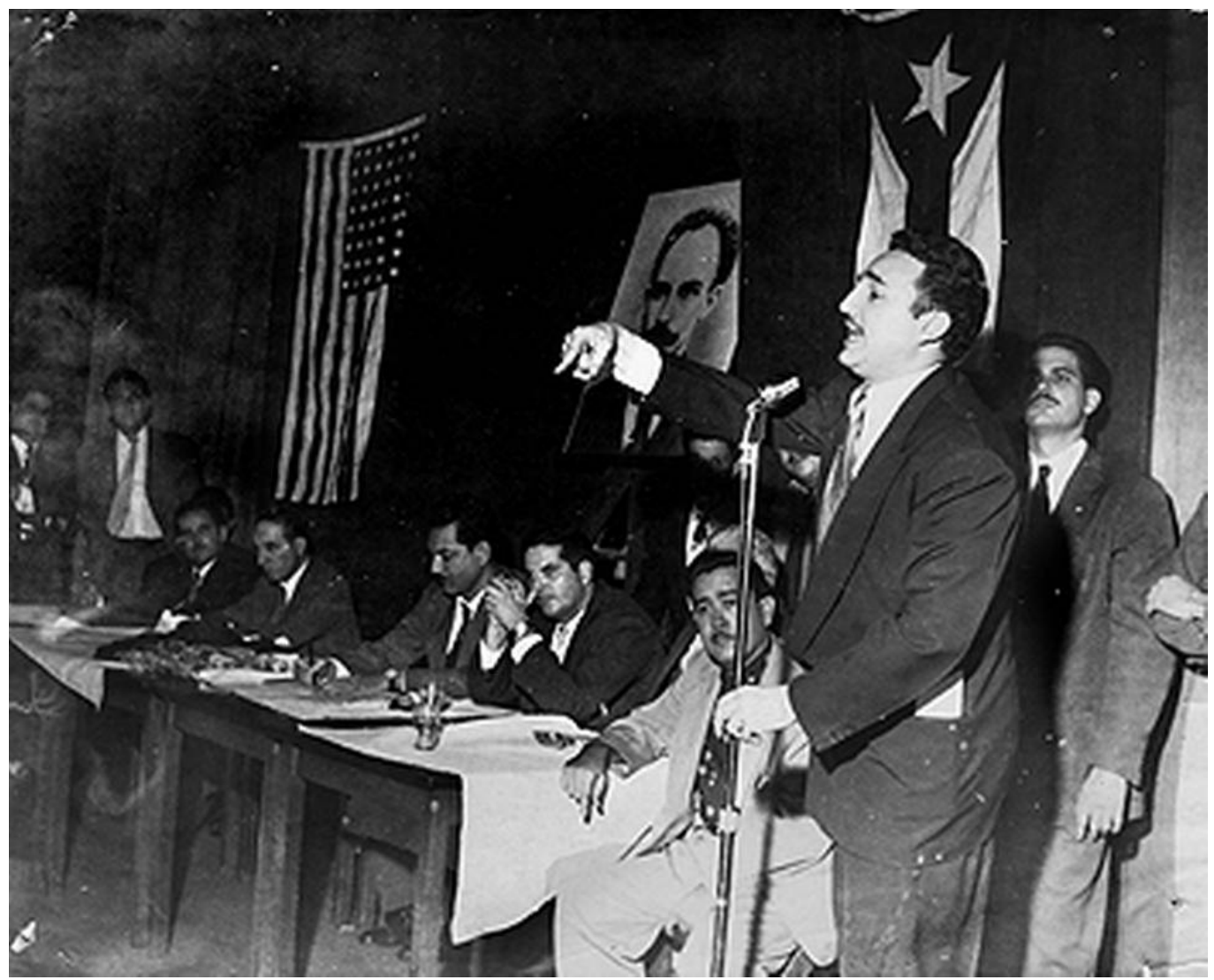

Figure E.2 Fidel Castro at Teatro Flagler, Miami, November 1955.

Other significant developments in Miami relative to Latin America included the founding of the first and longest-running Spanish-language newspaper in Miami, Diario Las Amércias, in 1953 by a Nicaraguan, Horacio

${ }^{18}$ Alfonso Chardy and Luisa Yanez, "Fidel Castro Once Used Miami as Haven, Revolutionary Springboard," Miami Herald, Jul. 25, 2008; Hugh Thomas, Cuba, 876-877, 968-973. 
Aguirre Baca, who chose Miami because of its location and substantial air routes. The Diario later championed the exiled Cuban political cause against communism on the island and promoted U.S.-friendly democracy throughout the continent. ${ }^{19}$ Ex-President Marco Pérez Jiménez of Venezuela went into exile in Miami in 1958. He was later extradited back to Venezuela to face charges for embezzlement. ${ }^{20}$ Undefined by country of origin, the Hispanic population in Dade County increased from 20,000 in 1950 to 35,000 in 1955 and to 50,000 in 1960, still a modest but growing percentage of the nearly 1 million county residents. Puerto Ricans and Cubans likely represented the major ethnic groups, with smaller populations Colombians, Venezuelans, Nicaraguans, Dominicans, and others. $^{21}$

The dramatic influx of Cubans and other Latin Americans after 1959 then followed established precedent. Miami already provided the political space of exile for two generations of Cubans and at least one Venezuelan ruler, in addition to established cultural links between the city and elites in Peru and Colombia. No matter the particular cause or political exigency involved, Miami always welcomed new avenues of capitalist investment and new strategic subjects to its realm, even if temporarily. Ease of travel to the city by air, the city's promoted Pan Americanism, the tropical landscape, and familiar architecture further

19 "Cumpleaños 90 del Fundador de Diario Las Américas," Diario Las Américas, Apr. 22, 2015.

${ }^{20}$ Juan Tamayo, "Miami Attractive to Exiled Rulers," Miami Herald, Oct. 21, 1998.

${ }^{21}$ Miami-Dade County Facts (Miami, FL: Miami-Dade County Department of Planning \& Zoning, 2009), 9. 
induced elite Latin American settlement in Miami. Clandestine operations by the CIA in Guatemala based in Miami in 1954, as discussed in the previous chapter, likewise provided precedent for future operations involving Cuban exiles. Miami was a growing, strategic, and imperial metropolis by the 1950s, not a dwindling tourist town.

\section{An Imperial Capital City: Miami after 1959}

U.S. planning and support distinguished later Cuban exiles in Miami compared to previous generations. Cuban exile juntas after 1959 formed under the explicit design of the White House and the CIA as part of an effort to make the resistance to Castro's government appear genuine and nationalist. ${ }^{22}$ Training Cuban exiles in the use of explosives and clandestine service in Miami and at the School of the Americas at Fort Benning, Georgia, though, unintentionally provided the expertise needed to hold the city's Cuban population hostage to an anti-Castro politics. Just as secure markets abroad mattered more than democracy for U.S. imperial interests, so too did acquiescence to a hardline stance against Castro matter more than freedom of expression for the imperial city's leading subjects.

${ }^{22}$ Lyman B. Kirkpatrick, "Inspector General Survey of the Cuban Operation," Central Intelligence Agency, Feb. 16, 1962, sanitized and declassified in 1997, Digital National Security Archive hereafter DNSA. 
Among the most notorious planners and bombers exhibiting a violent antiCastroism were Jorge Mas Canosa, Luis Posada Carriles, and Orlando Bosch. ${ }^{23}$ Most used bombs only to threaten resistant Cubans into providing funds for exile activities, but there were exceptions. ${ }^{24}$ Respected radio host Emilio Milián, a moderate voice in the Cuban community who criticized the use of bombs as a political weapon, lost both of his legs when a bomb exploded in his car in late April $1976 .^{25}$ Few exile terrorists faced prosecution because very often they simply became informants for one U.S. federal, state, or local law enforcement agency or another, playing the investigations of one agency off another to maintain deniability. ${ }^{26}$

1976 marked a year full of violence both in and outside Miami resulting from exile Cuban terrorist tactics. The Cuban Embassy in Madrid was bombed in April, killing two. In September, recently ousted Chilean President Salvador

23 "Cuban Focal Point in the Miami Area," The White House, Dec. 29, 1962, Sanitized and Declassified Aug. 9, 1984, DNSA; "Cuba..Progress Report," The White House, Jul. 12, 1963, DNSA; "Cuba Coordinating Committee - Progress Report," The White House, Jan. 17, 1963, DNSA; “Cuban Exiles' Proposed Meeting with President Somoza," United States Department of State, Mar. 30, 1970, Declassified Nov. 10, 2003, DNSA; "Report on Comite Pro Gobierno de Cuba En El Exilio (Committee for a Cuban Government in Exile)," Federal Bureau of Investigation, Apr. 25, 1975, Declassified Apr. 21, 1999, DNSA.

${ }^{24}$ Terry Johnson King, "Cuban Exiles Living with Reign of Terror," Miami News, Sep. 23, 1968; "Forty Bombings This Year," Miami News, Oct. 11, 1968.

${ }^{25}$ Edna Buchanan and Dorothy Gaiter, "Cuban Newsman Maimed As Bomb Explodes in Car," Miami Herald, May 1, 1976; Christopher Marquis and Lourdes Fernandez, "Explosion Hits Home in Gables, Call Links Blast to Cuba Talk," Miami Herald, May 27, 1988.

${ }^{26}$ John Rothchild, “The Informant," Harper's, Jan. 1982, 29-39. 
Allende's former ambassador, Orlando Letelier, and an American research assistant were killed by a car bomb in Washington, DC. The worst loss of life came when a Cubana de Aviación flight from Barbados to Cuba on October 6 exploded en route and killed all 73 passengers. Orlando Bosch, leader of the Coordination of Unified Revolutionary Organizations, claimed responsibility for the plane bombing. ${ }^{27}$ Bosch and two Venezuelans stood trial in Caracas for charges related to the bombing, but he escaped to Costa Rica, only to be arrested again. In a letter to Acción Cubana members in Miami, Bosch wrote from prison, "My only crime has been to fight for the freedom of my country with all of my strength. ${ }^{28}$ Bombs more than freedom and democracy maintained the hardline stance against Castro.

If in the 1960s a hardline anti-Castro, pro-U.S. imperial stance consolidated in the city, the 1970s ushered in new capital investments in Miami from Latin Americans eager to diversify their holdings and convinced that the city provided a stable alternative to volatile home economies where nationalist, leftist, and anti-U.S. forces ruled. Some examples of foreign investments included a meat production sales corporation from Argentina, a cold storage facility for imported cut flowers from Colombia, and an oil distribution venture from Venezuela. ${ }^{29}$

${ }^{27}$ Joe Crankshaw and Gloria Marina, "Miami a Hotbed for Terrorism," Miami Herald, Nov. 29, 1976; "Fidel Castro Denounces Aggressions Against Cuba," The Black Scholar, Vol. 8, No. 3 (Dec., 1976): 10-17.

28 "Report on Accion Cubana (Cuban Action) (AC)," Federal Bureau of Investigation, Jun. 29, 1976, declassified Oct. 1, 1997, DNSA.

${ }^{29}$ Mira Wilkins, Foreign Enterprise in Florida: The Impact of Non-U.S. Direct Investment (Miami, FL: Florida International University, 1979), 23. 
Venezuelans also began to invest heavily in Miami banks and land as a way to offset potential losses of revenue from nationalization of oil production. A conservative estimate put Venezuelan stock acquisitions in Miami banks at $\$ 35$ million and \$28 million in land purchases by $1979 .{ }^{30}$ Encouraging capital flight to Miami transgressed state policies designed to retain national wealth and enriched Miami's real estate and banking sector. The imperial city's gains limited national progress in Venezuela and elsewhere.

First National Bank of Miami, the only major bank to survive the 1926 real estate bust, garnered enormous foreign deposits in the 1960s and 1970s. FNB pioneered offshore banking in the Bahamas, setting up branches in Nassau. In the application for the Nassau branch on July 29, 1970, bank president Robert Bruce explained that, "Due to our close proximity to the developing Latin American countries, our deposits from those countries exceeded \$125 million on June 30, 1970. We believe these foreign deposits can be increased substantially by providing an off-shore depository. Additionally, over 35 Latin American headquarters of large United States corporations have been established in Coral Gables, a suburb of Miami, and we must be in a position to satisfy their increasing off-shore financing requirements. ${ }^{31}$ The Board of Governors of the Federal Reserve approved the request on Feb. 26, 1971, with the instruction that FNB not

\footnotetext{
${ }^{30}$ Mira Wilkins, "Venezuelan Investment in Florida: 1979," Latin American Research Review, Vol. 16, No. 1 (1981): 156-165.

${ }^{31}$ Letter from Robert Bruce to Board of Governors of the Federal Reserve System, July 29, 1970, in Southeast Bank Records, 1993-008, Box 1, Folder 8, at Charlton W. Tebeau Research Library, HistoryMiami.
} 
use Nassau as a way of shifting capital offshore. ${ }^{32}$ Beyond the purview of the Fed, offshore banks with U.S. headquarters, including FNB, acted as crucial intermediaries to launder money from the $\$ 50$ billion cocaine trade into legitimate Miami real estate and commercial investment, with locally invested funds totaling $\$ 7$ billion by the early 1980s. The local branch of the Federal Reserve Bank in Miami reported astonishing surpluses of $\$ 5.96$ billion by 1985 when the majority of other branches of the bank throughout the country reported net losses. ${ }^{33}$ The illicit trade restructured Colombian agricultural production to supply the U.S. market, but the profits remained in Miami rather than in the hands of the peasant producers.

The network of illicit cocaine traffic to fund the counter-revolutionary forces in Nicaragua came to public attention in the 1980s, as did Miami's central participation in the traffic. The U.S.-friendly dictatorial line of Somozas lost power in 1979, and CIA-contracted businesses in Nicaragua funneled drugs to Miami as weapons streamed back from Miami aboard private and commercial

\footnotetext{
${ }^{32}$ Letter from Boards of Governors of the Federal Reserve System to First National Bank of Miami, Feb. 26, 1971, Southeast Bank Records, 1993-008, Box 1, Folder 9, at Charlton W. Tebeau Research Library, HistoryMiami.

${ }^{33}$ Anthony P. Maingot, "Laundering the Gains of the Drug Trade: Miami and Caribbean Tax Havens," Journal of Interamerican Studies and World Affairs, Vol. 30, No. 2/3 (Sum.-Aut., 1988): 174-179; see also, Breandán Ó hUallachain, "Foreign Banking in the American Urban System of Financial Organization," Economic Geography, Vol. 70, No. 3 (Jul., 1994): 206-228; Eduardo Sáenz Rovner, "Las Redes de Cubanos, Norteamericanos, y Colombianos en el Narcotráfico en Miami Durante los Años Sesenta," Innovar: Revista de Ciencias Administrativas y Sociales, Vol. 18, No. 32 (Jul.-Dec., 2008): 111-126.
} 
aviation shell companies in order to win back control. ${ }^{34}$ The Nicaraguan exiles in support of the Somoza family's continued rule, somocistas, maintained their headquarters in Miami throughout the 1980s, with a population of roughly 20,000. Anastasio Somoza came to Miami after Sandinistas forced him to flee in 1979, but President Jimmy Carter suggested he leave because the U.S. could not guarantee his safety. Somoza was assassinated in Paraguay while in exile, and his body was brought back to Miami for burial at Woodlawn Cemetery, the final resting place of exiled Cuban presidents Gerardo Machado and Carlos Prío who also had been amenable to U.S. capital interests. ${ }^{35}$

Although he continued to fund covert operations including those in Nicaragua, Jorge Mas Canosa sought to normalize his political influence by creating the Cuban American National Foundation (CANF), which modeled its lobbying efforts after the American-Israel Public Affairs Committee following the suggestion of President Ronald Reagan's National Security Advisor Richard Allen. CANF financed campaigns for both Republicans and Democrats who bent to the anti-Castro line. Radio Martí represented one of his earliest congressional victories, and the first broadcast from Miami to Havana started in 1982. A young Jeb Bush managed the CANF-supported campaign of Ileana Ros-Lehtinen, the first Hispanic female member of Congress. Lincoln Díaz-Balart and other Cuban

\footnotetext{
34 "Pilots, Companies and Other Individuals Working for Companies Used to Support the Contra Program," Allegations of Connections Between CIA and The Contras in Cocaine Trafficking to the United States, Vol. 2 The Contra Story (Washington, DC: Office of Inspector General, 1996).

${ }^{35}$ Guillermo Cortés Domínguez, Miami: Secretos de Un Exilio (Managua, NA: Editorial El Amanecer, 1986); "Assassinated Dictator Somoza Buried in Miami Friday," Associated Press, Sep. 20, 1980.
} 
candidates received considerable funding from CANF. Key legislation to renew aggressive economic sanctions against Cuba like the Helms-Burton Act also gained CANF support and dollars. ${ }^{36}$ Jeb Bush's connection to the exile Cuban cause likely contributed to the full pardon by his father President George H.W. Bush of Orlando Bosch in 1990, who was facing extradition charges to return to Venezuela to resume in prison term. The elder Bush's former post as director of the CIA in the 1970s also meant he knew of Bosch's activities. Surreptitiously awarded via pardon for his clandestine service to U.S. imperial, Bosch lived out his life in Miami and died in 2011. ${ }^{37}$

Anti-Castro politics in Miami confronted a postcolonial reality when Nelson Mandela gave a speech in Miami in 1990. The Cuban-run local government offered no official welcome to Mandela on account of his friendship with Castro, and protesters maintained vigil outside during his speech. Noted historian of black Miami Marvin Dunn referred to it as a "snub for the ages." The consolidated anti-Castro politics of Miami proved so powerful that Human Rights Watch issue two separate reports in 1992 and 1994 concerning the lack of

${ }^{36}$ Saul Landau, "No Mas Canosa," Monthly Review, Vol. 50, No. 10 (1999); see also, Patrick J. Haney and Walt Vanderbush, The Cuban Embargo: The Domestic Politics of an American Foreign Policy (Pittsburgh, PA: University of Pittsburgh Press, 2005); David A. Fahrenthold, "Grounded TV Marti Plane A Monument to the Limits of American Austerity," Washington Post, Sep. 2, 2013.

${ }^{37}$ Douglas Martin, "Orlando Bosch, Cuban Exile, Dies at 84," New York Times, Apr. 27, 2011; see also, "Bush Ally Harbored Plane-Bomb Suspect," Miami Herald, Sep. 5, 1988.

${ }^{38}$ Howard W. French, "Mandela Travels to Miami Amid Protests Over Castro," New York Times, Jun. 29, 1990; Marvin Dunn, "A Snub for the Ages,"

Transitions, Vol. 116, Nelson Rolihlahla Mandela, 1918-2013 (2014): 98-105. 
freedom of speech in the city. "Ironically," one report noted, "in their attitude toward dissenting viewpoints, many anti-Castro Miami Cubans have a good deal in common with the regime they loathe. Freedom of expression suffers, much as it does in other countries in Latin America - or anywhere else in the world - where violence rules. ${ }^{, 39}$ The violence of anti-Castroism mirrored as much the many manifestations of U.S. imperialism throughout Latin America and the Third World as it did the political repression in Castro's Cuba. Hate for Castro more than love of democracy persisted as the decisive political force in Miami even after the Cold War's nominal end.

While hardline anti-Castro Cubans in Miami continued to hold positions of power, newer migrants from post-Revolution Cuba to Miami in the 1990s maintained transnational ties with family members on the island, more closely resembling normal patterns among migrant communities in the United States. The transnational networks and remittances sent back, sometimes obstructed by the hardliner Miami delegation in Congress but allowed during non-election years by both President Bill Clinton and President George W. Bush, more significantly worked as agents of change on the island than the decades of terrorism and economic sanctions. ${ }^{40}$

\footnotetext{
39 "Dangerous Dialogue: Attacks on Freedom of Expression in Miami's Cuban Exile Community," Americas Watch, Vol. 4, Issue 7 (Aug. 1992): 2; "Dangerous Dialogue Revisited: Threats to Freedom of Expression Continue in Miami's Cuban Exile Community," Americas Watch, Vol. 6, No. 14 (Nov. 1994); Larry Rohter, "Miami Leaders Are Condemned by Rights Unit," New York Times, Aug. 19, 1992.

${ }^{40}$ Susan Eva Eckstein, The Immigrant Divide: How Cuban-Americans Changed the U.S. and their Homeland (New York: Routledge, 2009).
} 
Barack Obama, in explicit defiance of the CANF's lobbying power, ran on a campaign promise in 2008 to end the embargo, to close the Guantánamo detention center on the U.S. naval station - the most durable symbol of U.S. imperial power in Cuba - and to begin normalization of relations. ${ }^{41}$ By 2011, a Florida International University poll found that a majority of Miami Cubans wanted to normalize relations and end the embargo, a first in almost twenty years of polling. ${ }^{42}$ Hardliners still spoke loudly through their powerful positions, exemplified in the forced suspension of the Venezuelan-born Miami Marlins manager Ozzie Guillen for saying he supported Castro in $2012 .^{43}$ The poll likely influenced President Obama's decision in 2011 to secretly begin the normalization process, formally announced on December 17, 2014, and known affectionately as 17D on the island. In March 2016, Obama became the first sitting president to visit Cuba since Calvin Coolidge gave his Pan American Conference address in 1928 discussed in chapter four. ${ }^{44}$ By no means indicative of an end or zenith of U.S. imperial ambitions, the Obama visit instead signals a

${ }^{41}$ Michael D. Shear, "For Obama, More Audacity and Fulfillment of Languishing Promises," New York Times, Dec. 17, 2014.

${ }^{42}$ Juan Antonio Blanco, Uva de Aragón, Jorge Duany, Jorge I. Domínguez, Carmelo Mesa-Lago, and Orlando Márquez, The Cuban Diaspora in the $21^{s t}$ Century (Miami, FL: Cuban Research Institute - Florida International University, 2011).

${ }^{43}$ Edgar Thompson and Juliet Macur, "In Miami, Winning Isn't Everything," New York Times, Apr. 10, 2012.

${ }^{44}$ Damien Cave, "With Obama Visit to Cuba, Old Battle Lines Fade," New York Times, Mar. 26, 2016. 
willingness to recapitalize markets like Cuba rendered dormant by Cold War policies, policies supported and held dear by Miami's anti-Castro Cubans.

\section{Whose Capital is It Anyway?}

A 2009 financial report on 1,146 multinational companies with regional or global headquarters in Miami, representing 53 countries, found that the combined overseen annual revenues of these companies totaled \$221 billion, higher than the GDPs of Peru, Colombia, and Chile. U.S.-owned firms constituted over half of the companies studied, and only five foreign firms made the top-twenty list in terms of revenue, and none of those were Latin American companies. ${ }^{45}$ Although Miami facilitates capital flows between the Americas on a scale incomparable to any other city, the vast majority of that capital flows back into the United States. "Latin America" originated as a strategic geopolitical essentialism constructed from a U.S. imperial view of the world as one of many conquerable and knowable regions. ${ }^{46}$ Miami, a U.S. imperial city, then serves well as the capital of that construct.

With the major Spanish-language media networks like Univision, Telemundo, Fusion, as well as the production facilities for the most popular telenovelas based in Miami, the city single-handedly cultivates the image of an elite pan-Latino identity, all the while dependent on working-class migrants from

${ }^{45}$ The 2009 Who's Here Multinational Economic Impact Study (Coral Gables, FL: World City, 2009), 1-6.

${ }^{46}$ See Thomas H. Holloway, "Latin America: What's in a Name?" adapted from his introductory essay in A Companion to Latin American History (Waltham, MA: Wiley/Blackwell, 2008). 
throughout the Caribbean and Latin America without the resources or access to enjoy the exclusive pleasures of the imperial city. ${ }^{47}$ One elite Mexican woman told the Miami Herald in 2004 that she chose to move her family to Miami instead of Los Angeles or Mexico City because "what I love most is the freedom to go out into the streets with my sons without fearing that we're going to be kidnapped or robbed or that my children's health is going to suffer." 48 María Elena Salinas, the Mexican host of Miami-based Noticiero Univision and Aquí y Ahora, likewise prefers Miami instead of Los Angeles. "We are the leaders of this community," Salinas said, "the owners of the banks, the attorneys and the famous architects. It gives you a sense of pride." ${ }^{49}$ The pride felt by Salinas and other wealthy Latin Americans in Miami is not a nationalist pride of country but a deterritorialized, de-nationalized pride in the imperial city.

Pride in an elite Latino culture in Miami regardless of national origin does not mean the city ignores politics throughout the hemisphere. The most important political consultant in Latin American campaigns for right-wing candidates, Venezuelan-born J.J. Rendón, conducts his business from Miami. Recent accusations from a convicted hacker and alleged employee of Rendón, Andrés Sepúlveda, implicate both men in tactics of political espionage, vote-rigging, and

${ }^{47}$ George Yúdice, "Miami: Images of a Latinopolis," NACLA Report on the Americas (Nov.-Dec., 2005): 35-40; see also, John Sinclair, "'The Hollywood of Latin America': Miami as Regional Center in Television Trade," Television \& New Media, Vol. 3, No. 4 (Aug., 2003): 211-229.

${ }^{48}$ Fabiola Santiago, "Mexicans Finding Rich Lives in Miami," Miami Herald, May 5, 2004.

${ }^{49}$ Ibid. 
disinformation blitzes in campaigns in Colombia, Mexico, Venezuela, Ecuador, and elsewhere over the past decade. Rendón denies the allegations and says he only paid Sepúlveda for website design. ${ }^{50}$ Regardless, Miami continues to do the work for open markets in Latin American at whatever cost, the same work once conducted from Miami of Pan American Airways and the CIA.

Over the last two decades, continued capital flight from Brazil, Venezuela, Mexico, and elsewhere has financed a dramatic increase in downtown Miami high-rise condos. ${ }^{51}$ The U.S. Treasury Department's Financial Crimes Enforcement Network (FinCEN) targeted Miami in January 2016 as one of two sites, along with Manhattan, to monitor all cash transactions in real estate over $\$ 1$ million dollars. ${ }^{52}$ Shell companies purchasing high-end Miami real estate often hide illicit funds through legitimate purchases in Miami, a legacy of the speculative 1920s boom as well as the cocaine capitalism of the 1970s-1980s. One illustrative example involved a governor of the State of Brasilia, Paulo Octávio Alves Pereira, indicted for accepting millions in bribes, who purchased a \$2.95 million condo in the elite Bal Harbor high-rise St. Regis in 2011 through a

${ }^{50}$ Jordan Robertson, Michael Riley, and Andrew Willis, "How to Hack an Election,” Bloomberg Businessweek, Mar. 31, 2016.

${ }^{51}$ Lizette Alvarez, "Influx of South Americans Drives Miami's Reinvention," New York Times, Jul. 19, 2014; Reed Johnson and Luciana Magalhaes, "Miami Emerges as Fertile Ground for Brazilian Babies," Wall Street Journal, Dec. 24, 2015; Josh Boak and Jennifer Kay, "As Wealthy Brazilians Snap Up Miami Real Estate, Few Benefit,” Associated Press, Jan. 19, 2016.

52 "FinCEN Takes Aim at Real Estate Secrecy in Manhattan and Miami," Press Release, Jan. 13, 2016, United States Department of the Treasury - Financial Crimes Enforcement Network. 
shell company ${ }^{53}$ The recently leaked documents from the law firm MossackFonseca, known as the Panama Papers, uncovered secretive networks of wealth circulation on a global scale. One of the firm's busiest offices, of course, is in Miami, and the Miami Herald is the only American newspaper involved in the ongoing investigation of the leaked documents because of the city's lead role in the shadow economy. ${ }^{54}$

The imperatives of global capitalism, forces shaping Miami for decades, seem to finally outweigh the ideological baggage of the twentieth-century.

Fiercely anti-Castro Cubans in Miami, once the bastions of anti-communism, now appear as an anachronism in a post-ideological global capitalist landscape. "I can tell you one thing that became very clear to me," said Cuban American businessman and longtime supporter of the embargo Paul Cejas, after whom the FIU School of Architecture is named, "The embargo is really an embargo against America ourselves. Because Americans cannot do business with Cuba, where there are incredible opportunities for growth. ${ }^{, 55}$ Cejas, sugar magnate Alfonso Fanjul, and several other wealthy Cuban-Americans have begun to voice their doubts about the wisdom of the decades-old embargo, a political impossibility only a few years ago. Many elite Cuban-Americans even investigated potential

\footnotetext{
${ }^{53}$ Nicholas Nehamas, "How Secret Offshore Money Helps Fuel Miami's Luxury Real-Estate Boom," Miami Herald, Apr. 3, 2016.

${ }^{54} \mathrm{Ibid}$; for more on the Panama Papers, see the International Consortium of Investigative Journalists website: panamapapers.icij.org.

${ }^{55}$ Peter Wallsten, Manuel Roig-Franzia, and Tom Hamburger, "Sugar Tycoon Alfonso Fanjul Now Open to Investing in Cuba Under 'Right Conditions'," Washington Post, Feb. 2, 2014.
} 
investments on the island they once held at arm's length during President Obama's visit to Havana. ${ }^{56}$ After decades of privileges, the Cuban-American contingent in Congress is also attempting to undo the mechanisms of support that positioned them in power to begin with, as systemic abuses come to light. ${ }^{57}$ The complaints of Miami-Dade County Mayor Carlos Gimenez that his children, born in the United States, could travel to Cuba aboard the new Carnival cruise line from Miami but that he, being a Cuban-born Miami resident, could not provides a useful gauge for how quickly the vitriol of anti-Castroism has shifted toward capitalist engagement. ${ }^{58}$

\section{Conclusion: A Requiem for the Viceroyalty}

More than anything else, this dissertation highlights continuities as well as change. Colonial continuities connected sixteenth-century Spanish efforts to settle south Florida and renewed nineteenth-century U.S. efforts. Tropical dreams of Miami mattered as much for Mars Corporation in the twenty-first century as they did for a doctor in Mexico in the nineteenth-century. A nostalgic appropriation of Spanish architecture reiterated patterns of frontier settlement separated by several centuries. The struggle to control the skies continues in the post-9/11 world, in

\footnotetext{
${ }^{56}$ Patricia Mazzei, "Miami’s Cuban-American Business Elite Spent Spring Break in Havana," Miami Herald, Mar. 25, 2016.

57 James Rosen, "Sen. Marco Rubio Seeks to End Special Refugee Status for Cuban Migrants," Miami Herald, Apr. 13, 2016.

${ }^{58}$ Douglas Hanks, "Miami-Dade Mayor Calls on Carnival to Cancel Cruise to Cuba if Cuban-Born Americans Can't Buy Tickets," Miami Herald, Apr. 13, 2016.
} 
part the product of pioneering civilian and military flight training over Biscayne Bay a century ago. Pursuits of controlled markets and stable regimes throughout the hemisphere beckoned likeminded elites to Miami's shores to lead the work on behalf of their imperial city.

Miami's future as an imperial city, though, may not last. Forecasts of rising ocean levels and the increase of already significant saltwater incursions precariously position the city at the sinking edge of climate change. ${ }^{59}$ The consequences of human industry and resource depletion throughout the world, the engines and entrails of global capitalism, already exist but their full extent still not fully known. Fittingly, the discovery of the New World prompted Thomas More to rewrite Plato's mythical tale of Atlantis that lost the favor of the gods and sank below the sea. If the dire predictions for the future come to pass, Miami will be lost like the mythical Atlantis. The wrath of capital, not gods, exacts a heavy toll.

${ }^{59}$ Jeff Goodell, "Goodbye, Miami," Rolling Stone, Jun. 20, 2013; Laura Parker, "Treading Water," National Geographic, Feb. 2015. 


\section{REFERENCES}

Primary Sources

The 2009 Who's Here Multinational Economic Impact Study. Coral Gables, FL: World City, 2009.

Alvarez, Lizette. "Influx of South Americans Drives Miami's Reinvention." New York Times, Jul. 19, 2014.

Annual Reports of the Canal Zone Experiment Gardens for Fiscal Year 1933 and 1934. Mount Hope, CZ: Panama Canal Press, 1938.

Amuchastegui, Domingo. "Cuban Intelligence and the October Crisis." Intelligence and National Security, Vol. 13, No. 3 (1998): 88-119.

Ballinger, Kenneth. Miami Millions: The Dance of the Dollars in the Great Florida Land Boom of 1925. Miami, FL: Franklin Press, 1936.

Banfield, Edward C. Big City Politics - A Comparative Guide to the Political Systems of Atlanta, Boston, Detroit, El Paso, Los Angeles, Miami, Philadelphia, St. Louis and Seattle. New York: Random House, 1965.

Bartram, William. Travels through North \& South Carolina, Georgia, East \& West Florida, The Cherokee Country, The Extensive Territories of the Muscogulges, or Creek Confederacy, and the Country of the Chactaw: Containing An Account of the Soil and Natural Productions of those Regions, Together with Observations on the Manners of the Indians, Embellished with Copper Plates. Philadelphia, PA: James and Johnson, 1791.

Bearak, Barry. "Hijackers - They're Still Flying High.” Los Angeles Times, Aug. 4, 1983.

Beecher Stowe, Harriet. Palmetto-leaves. Boston: J.R. Osgood and Company, 1873.

Biscayne Bay Yacht Club records, 1909-1970. Charlton W. Tebeau Research Library, HistoryMiami.

Blackman, Ethan V. Miami and Dade County, Florida: Its Settlement, Progress and Achievement. Washington, DC: Victor Rainbolt, 1921.

Blanco, Juan Antonio, Uva de Aragón, Jorge Duany, Jorge I. Domínguez, Carmelo Mesa-Lago, and Orlando Márquez. The Cuban Diaspora in the $21^{\text {st }}$ Century. Miami, FL: Cuban Research Institute - Florida International University, 2011. 
Boak, Josh, and Jennifer Kay. “As Wealthy Brazilians Snap Up Miami Real Estate, Few Benefit.” Associated Press, Jan. 19, 2016.

Booth, Cathy. "Miami: the Capital of Latin America." Time, Jun. 24, 2001.

A Brief History of Marine Corps Aviation. Washington, DC: Department of the Navy Headquarters United States Marine Corps, 1962.

Buchanan, Edna, and Dorothy Gaiter. "Cuban Newsman Maimed As Bomb Explodes in Car." Miami Herald, May 1, 1976.

Buschschulter, Vanessa. "The Long History of Trouble Ties Between Haiti and the U.S." BBC News, Jan. 16, 2010.

Cave, Damien. "With Obama Visit to Cuba, Old Battle Lines Fade." New York Times, Mar. 26, 2016.

Cellon, George B. Descriptive List of Commercial Varieties of Tropical Fruit Trees. Miami, FL: privately printed by author, 1907.

Chardy, Alfonso. "Opa-Locka Field Was Once The Site of Secret CIA Base." Miami Herald, Apr. 20, 2013.

Chardy, Alfonso, and Luisa Yanez. "Fidel Castro Once Used Miami as Haven, Revolutionary Springboard.” Miami Herald, Jul. 25, 2008.

Chester, Craig. "Miami’s Suburbs in the Sky.” Next City, May 21, 2012.

Clark, Cammy. "100 Years Ago, Aviation Pioneer Made Historic Flight from Key West to Cuba." Miami Herald, May 16, 2013.

Clark, Charles Eugene. A Tribute to the Life and Memory of that Princely American, the Late Henry M. Flagler, Through whose Splendid Efforts in Reclamation, Railways, Hotel and City Building, Florida, the Land of the Palm and Pine, was largely made Possible, and Habitable, and a Nation's Playground. Covington, KY: privately printed by the author, 1914.

Cloud, David S. “Top Officers' Quarters are Their Castles.” Los Angeles Times, Jul. 21, 2013.

Cohen, Isidor. Historical Sketches and Sidelights of Miami, Florida. Miami, FL: privately printed by the author, 1925 .

Committee of 100 Scrapbooks. Charlton W. Tebeau Research Library, HistoryMiami. 
Corporate Press Release for North America, "Mars, USDA-ARS, and IBM Unveil Preliminary Cacao Genome Sequence Three Years Ahead of Schedule," September 2010 .

Cortés Domínguez, Guillermo. Miami: Secretos de Un Exilio. Managua, NA: Editorial El Amanecer, 1986.

Crankshaw, Joe, and Gloria Marina. "Miami a Hotbed for Terrorism." Miami Herald, Nov. 29, 1976.

Crowther, Samuel. The Romance and Rise of the American Tropics. New York: Doubleday, Doran, and Co., 1929.

de las Casas, Bartolomé. A Brief Account of the Destruction of the Indies. London: R. Hewson, 1689.

de Onís, Luis. Memoir upon the Negotiations between Spain and the United States, which led to the Treaty of 1819. Translated by Tobias Watkins.

Washington, DC: E. De Kraft, 1821.

Dickinson, Jonathan. God's Protecting Providence, Man's Surest Help and Defence, in Times of the Greatest Difficulty, and most Eminent Danger.

Evidenced in the Remarkable Deliverance of Robert Barrow, with divers other Persons, from the Devouring Waves of the Sea, amongst which they suffered Shipwrack: and also, From the cruel Devouring Jaws of the Inhumane Canibals of Florida. Philadelphia: Society of Friends, 1699.

Dietrich, Emily, Elise Brault-Hoessly, Robert Carr, and Michael Zimny. "The Charles Deering Estate." Nomination Form for National Registry of Historic Places, Jan. 1986.

Display Ad 76, May 26, 1921, 9; Display Ad 66, May 27, 1921, 12; Display Ad 78, May 31, 1921, 11; Display Ad 56, Jun. 6, 1921, 8; Display Ad 25, Jun. 13, 1921, 16; Display Ad 67, Jun. 20, 1921, 13; Display Ad 113, Jun. 27, 1921, 21; Display Ad 55, Jul. 5, 1921, 11; Display Ad 72, Jul. 10, 1921, 29; Display Ad 30, , Jul. 25, 1921, 6. The New York Times.

Dodge, Charles Richard. "Report of the Special Agent in Charge of Fiber Investigations." Report of the Secretary of Agriculture, 32nd Congress, Second Session, House of Representatives, Executive Document 1, Part 6. Washington, DC: Congressional Printing Office, 1893.

Dorn, Harold W. "Mango Growing Around Early Miami." Tequesta, Vol. 16 (1956): 37-53. 
Dr. Henry Perrine, Tropical Plants. Washington, DC: Congressional Printing Office, 1838.

The Eighteenth Decennial Census of the United States. US Bureau of the Census, Vol. 1, Part 11, Florida. Washington, DC: US Government Printing Office, 1963.

Engels, Friedrich to Friedrich Graeber. "Florida." Jan. 20, 1839, Bremen, Germany. Accessible via Marxist Internet Archive.

Fahrenthold, David A. "Grounded TV Marti Plane A Monument to the Limits of American Austerity." Washington Post, Sep. 2, 2013.

Fairchild, David. The World Grows Round My Door: The Story of the Kampong, A Home on the Edge of the Tropics. New York: Scribners, 1947.

Fairchild, David. The World Was My Garden: Travels of a Plant Explorer. New York: Scribners, 1938.

Fairchild, David. "Our Plant Immigrants: An Account of Some of the Results of the Work of the Office of Seed and Plant Introduction of the Department of Agriculture and of Some of the Problems in Process of Solution." National Geographic, Vol. 17, No. 4 (1906): 179-201.

Fairchild, David. "Personal Recollections of George B. Cellon, Horticultural Pioneer of South Florida." Proceedings of the Florida State Horticultural Society, Vol. 54 (1945): 205-209.

Fairchild, David. "Some Plant Reminiscences of Southern Florida." Tequesta, Vol. 2 (1941): 8-15.

Firestone, Harvey, and Samuel Crowther. Men and Rubber: The Story of Business. New York: Doubleday, Page, and Co., 1926.

Flying the Lindbergh Trail. Produced and photographed by Palmer Miller and Curtis F. Nagel. New York: Pan American Airways, 1937. Film.

Foreign Relations of the United States, 1952-1954, Guatemala, edited by Susan Holly. Washington, DC: Government Printing Office, 2003.

Fountain, Henry. "Julia Morton, 84, An Expert of Florida's Poisonous Plants." Obituary, New York Times, September 14, 1996.

Frank, Dana. "In Honduras, a Mess Made in the U.S." New York Times, Jan. 26, 2012. 
Frazure, Hoyt, with Nixon Smiley. Memories of Old Miami. Miami, FL: Miami Herald, 1964.

French, Howard W. "Mandela Travels to Miami Amid Protests Over Castro." New York Times, Jun. 29, 1990.

Garrison, William Lloyd, and H.C. Wright. "The Bloodhound Candidate." The Liberator, Jun. 30, 1848, Issue 26.

George Merrick Papers. Charlton W. Tebeau Research Library, HistoryMiami.

Goodell, Jeff. “Goodbye, Miami.” Rolling Stone, Jun. 20, 2013.

Griffitts, T.H.D., and J.J. Griffitts. "Mosquitoes Transported by Airplane: Staining Method Used in Determining Their Importation." Public Health Reports, Vol. 46, No. 47 (Nov. 20, 1931): 2775-2782.

A Guide to the Architecture of Miami. Miami, FL: Florida South Chapter, American Institute of Architects, 1963.

Hammon, Breton. A Narrative of the Uncommon Sufferings, and Surprizing Deliverance of Briton Hammon, a Negro Man,--Servant to General Winslow, of Marshfield, in New-England; Who Returned to Boston, After Having Been Absent Almost Thirteen Years. Containing an Account of the Many Hardships He Underwent from the Time He Left His Master's House, in the Year 1747, to the Time of His Return to Boston.--How He Was Cast Away in the Capes of Florida;--The Horrid Cruelty and Inhuman Barbarity of the Indians in Murdering the Whole Ship's Crew;---The Manner of His Being Carry'd by Them Into Captivity. Also, an Account of His Being Confined Four Years and Seven Months in a Close Dungeon,---and the Remarkable Manner in Which He Met with His Good Old Master in London; Who Returned to New-England, a Passenger in the Same Ship. Boston: Green Russel, 1760.

Hanks, Douglas. "Miami-Dade Mayor Calls on Carnival to Cancel Cruise to Cuba if Cuban-Born Americans Can’t Buy Tickets.” Miami Herald, Apr. 13, 2016.

Harakas, Margo. "Remember the Alamo.” Sun-Sentinel, Apr. 14, 1997.

Hochstein, Joshua. “Announcements.” Hispania, Vol. 17, No. 2 (May, 1934): 207-212.

Howson, L.R. "New Miami, Florida Water Softening Plant.” American Water Works Association, Vol. 18, No. 4 (Oct., 1927): 442-454.

An International Trade Statistical Report on the Port of Miami, Florida \& Miami International Airport. Tallahassee, FL: Florida Development Commission, 1956. 
Johnson, Captain Charles. A General History of the Pyrates, from Their Rise and Settlement in the Island of Providence, to the present Time. London: T. Warner, 1724.

Johnson, Reed, and Luciana Magalhaes. "Miami Emerges as Fertile Ground for Brazilian Babies.” Wall Street Journal, Dec. 24, 2015.

Johnson King, Terry. "Cuban Exiles Living with Reign of Terror.” Miami News, Sep. 23, 1968.

King, George R. "A Miami Architect's Work in Concrete." The Concrete Age, Feb. 1915, 11-12.

Kipp, Robert, Lynn Peake, and Herman Wolk. Strategic Air Command Operations in the Cuban Missile Crisis of 1962, Historical Study No. 90, Vol. 1. Washington, DC: United States Air Force, 1963.

Kirkpatrick, Lyman B. "Inspector General Survey of the Cuban Operation." Central Intelligence Agency, Feb. 16, 1962. Sanitized and declassified in 1997, Digital National Security Archive (DNSA).

Le Corbusier. Aircraft. London: Trefoil, 1935.

Loomis, H.F. “Activities of the U.S. Plant Introduction Garden.” USDA Agricultural Research Service (1957).

Marquis, Christopher, and Lourdes Fernandez. "Explosion Hits Home in Gables, Call Links Blast to Cuba Talk.” Miami Herald, May 27, 1988.

Martin, Douglas. "Orlando Bosch, Cuban Exile, Dies at 84." New York Times, Apr. 27, 2011.

Mazzei, Patricia. "Miami’s Cuban-American Business Elite Spent Spring Break in Havana." Miami Herald, Mar. 25, 2016.

Memoir of Don D'Escalante Fontaneda Respecting Florida, Written in Spain, about 1575. Revised and reprinted by the Historical Association of Southern Florida and the University of Miami. Coral Gables, FL: Parker Art Printing, 1944.

Memoirs of General Andrew Jackson, together with the Letter of Mr. Secretary Adams, in Vindication of the Execution of Arbuthnot and Ambrister, and the other Public Acts of Gen. Jackson, in Florida. Bridgeton, N.J.: Simeon Sigfried, 1824.

Merrick, George E. "Pre-Flagler Influences on the Lower Florida East Coast." Tequesta, Vol. 1 (1941): 1-10. 
Miami. New York: Montray Corporation, Oct. 1921.

Miami-Dade County Facts. Miami, FL: Miami-Dade County Department of Planning \& Zoning, 2009.

Miller, Hunter, ed. Treaties and other International Acts of the United States of America, Vol. 2, Doc. 1-40: 1776-1818. Washington, DC: Government Printing Office, 1931.

Moloney, W.M. "After Miami Beach - South America or the Caribbean?" American Bar Association Journal, Vol. 45, No. 5 (May, 1959): 492-494.

Nehamas, Nicholas. "How Secret Offshore Money Helps Fuel Miami's Luxury Real-Estate Boom.” Miami Herald, Apr. 3, 2016.

Parker, Laura. "Treading Water.” National Geographic, Feb. 2015.

Perez, Maria. "Spanish Royalty in Miami to Celebrate 500-year Link to Florida." Miami Herald, Nov. 18, 2013.

Pfeiffer, Jack B. Official History of the Bay of Pigs Operation. Vol. 1, Air Operations, March 1960 - April 1961, Part 1. Langley, VA: Central Intelligence Agency, 1979, sanitized and approved for release July 25, 2011.

Pollog, Carl Hanns. "Commercial Aviation in the American Mediterranean." Geographical Review, Vol. 27, No. 2 (Apr., 1937): 255-268.

Popenoe, Wilson. Manual of Tropical and Subtropical Fruits, Excluding the Banana, Coconut, Pineapple, Citrus Fruits, Olive, and Fig. New York:

Macmillan, 1920.

President Monroe's Message at the Commencement of the First Session of the Eighteenth Congress, Dec. 2, 1823.

Proceedings of the International Symposium on Plant Introduction, November 30December 2, 1966. Tegucigalpa, Honduras: Escuela Agricola Panamericana, 1967.

Rainbolt, Victor. The Town that Climate Built: The Story of the Rise of a City in the American Tropics. Miami, FL: Parker Art, 1925.

Reichhardt, Tony. “The First Presidential Flight.” Air \& Space Magazine, Jan. 18, 2013. 
Roberts, Kenneth L. Sun Hunting: Adventures and Observations among the Native and Migratory Tribes of Florida, including the Stoical Time-Killers of Palm Beach, the Gentle and Gregarious Tin-Canners of the Remote Interior, and the Vivacious and Semi-Violent Peoples of Miami and Its Purlieus. Indianapolis, IN: Bobbs-Merrill, 1920.

Robertson, Jordan, Michael Riley, and Andrew Willis. "How to Hack an Election." Bloomberg Businessweek, Mar. 31, 2016.

Rohter, Larry. "Miami Leaders Are Condemned by Rights Unit." New York Times, Aug. 19, 1992.

Rosen, James. "Sen. Marco Rubio Seeks to End Special Refugee Status for Cuban Migrants." Miami Herald, Apr. 13, 2016.

Rothchild, John. “The Informant.” Harper's, Jan. 1982, 29-39.

Santiago, Fabiola. "Mexicans Finding Rich Lives in Miami." Miami Herald, May $5,2004$.

Schaeffer, Wendell G. "Miami Looks at the Problems of Metropolitan Government." Public Administration Review, Vol. 15, No. 1 (Win., 1955): 35-38.

Semes, Aretta L. "From Rising Sun to Daunting Storm: Miami in Boom and Bust, A Reminiscence." Tequesta, Vol. 58 (1998): 91-110.

Shear, Michael D. "For Obama, More Audacity and Fulfillment of Languishing Promises." New York Times, Dec. 17, 2014.

Simpson, Charles Torrey. In Lower Florida Wilds: A Naturalist's Observations on the Life, Physical Geography, and Geology of the More Tropical Part of the State. New York: Putnam, 1920.

Simpson, Charles Torrey. Ornamental Gardening in Florida: A Treatise on the Decorative Plants Adapted to Florida and their Cultivation, with Suggestions for the Ornamentation of Florida Homes and Grounds. Little River, FL: printed by the author, 1916.

Simpson, Charles Torrey. "Native and Exotic." Proceedings of 25th Annual Meeting of the Florida Horticultural Society (1912): 166-207.

Small, John Kunkel. Flora of Miami. New York: privately printed by author, 1913. 
Smart, Alice. "Fruit Trees for Florida Homes." Department of Agriculture.

Tallahassee, FL: Florida Nursery and Landscape Company, 1960. "Fruit" Folder, Pamphlet Section "F", Charlton W. Tebeau Research Library, HistoryMiami.

Sofen, Edward. A Report on Politics in Greater Miami. Cambridge, MA: Joint Center for Urban Studies of MIT and Harvard University, 1961.

Soudder, N.F., and H.W. Kirschbaum. A Preliminary Determination of Normal Accelerations of Racing Airplanes, Technical Note No. 537. Washington, DC: National Advisory Committee for Aeronautics, 1935.

Southeast Bank Records. Charlton W. Tebeau Research Library, HistoryMiami.

Southerland Family Papers. Charlton W. Tebeau Research Library, HistoryMiami.

Stoneman Douglas, Marjory. Coral Gables: America's Finest Suburb, Miami, Florida. Miami, FL: Parker Arts Printing, 1926.

The Story of Coral Gables. Miami, FL: Parker Art Printing, 1926.

Sturrock, David. Notes on the Mango. Stuart, FL: Stuart News, 1944. "Fruit" Folder, Pamphlet Section "F", Charlton W. Tebeau Research Library, HistoryMiami.

Tamayo, Juan. "Miami Attractive to Exiled Rulers." Miami Herald, Oct. 21, 1998.

Tarbell, Ida. "Florida - and Then What? Impressions of the Boom." McCall's Magazine, Vol. 53 (May, 1926): 6-7, 57, 89-92.

Thomas, Evan. "'You Can Own the World'." Washington Post, Oct. 22, 1995.

Thomas, John F. "Cuban Refugees in the United States." International Migration Review, Vol. 2 (Spr., 1967): 46-57.

Thompson, Edgar, and Juliet Macur. "In Miami, Winning Isn't Everything." New York Times, Apr. 10, 2012.

Trippe, Juan T. "Foreign Trade in the Air Age." Hispania, Vol. 29, No. 1 (Feb., 1946): 104-108.

Tuma, Debbie. "Montauk Embraces Its Legacy.” New York Times, Aug. 11, 2002, LI 11. 
Viglucci, Andres, and Manny Garcia. "Hijack Plotters Used S. Florida as a Cradle for Conspiracy.” Miami Herald, Sep. 15, 2001.

Wallsten, Peter, Manuel Roig-Franzia, and Tom Hamburger. "Sugar Tycoon Alfonso Fanjul Now Open to Investing in Cuba Under 'Right Conditions'." Washington Post, Feb. 2, 2014.

Warner Bellah, James. “The Miami-Panama Air Mail Route." Aero Digest, Vol. 14, No. 5 (May, 1929): 43-44.

Weigall, Theyre. Boom in Florida. London: Bodly Head Limited, 1931.

Wilcox, H. Case. "Air Transportation in Latin America." Geographical Review, Vol. 20, No. 4 (Oct., 1930): 587-604.

Wilgas, A. Curtis. "The Teaching of Latin-American History in Secondary Schools." Hispania, Vol. 23, No. 1 (Feb., 1940): 65-66.

Wings Up. Produced by the First Motion Picture Unit, Army Air Forces. Washington, DC: Office of War Information, Bureau of Motion Pictures, 1943. Film.

Wolfe, H.S., L.R. Toy, and A.L. Stohl. "Avocado Production in Florida." USDA Agricultural Extension Service, Bulletin 141 (Dec., 1949). "Fruit” Folder, Pamphlet Section "F", Charlton W. Tebeau Research Library, HistoryMiami.

Wolff, Reinhold P. Miami Metro: The Road to Urban Unity. Coral Gables, FL: University of Miami, 1960.

The World's Columbian Exposition, Chicago, 1893: A Full Description of the Buildings and Exhibits in All Departments, edited by Trumbull White. Chicago and Philadelphia: International Publishing, 1893.

Wright, Johnson. "Florida Air News.” Aero Digest, Vol. 13 (Jul., 1928): 164.

"73 Lost in Akron Crash, 3 Survivors Here; Ship Driven Down in Storm, Cause is Unknown; Rescue Blimp Falls, 2 Killed, 5 Are Saved." New York Times, Apr. 5, 1933.

"Air Mail to Foreign Countries and Insular Possessions of the United States." United States Senate, 70th Congress, 1st Session, Report No. 311, Feb. 15, 1928.

“An Air Transport Record." Aviation and Aircraft Journal, Vol. 9, No. 11 (Nov. 29, 1920): 345. 
"Aircraft Production in the United States." United States Senate, 65th Congress, 2nd Session, Report No. 555, Aug. 22, 1918.

“The Alamo." Historical Preservation Report of City of Miami, Sep. 15, 1982.

"Amend the Air Mail Act of February 2, 1925." United States House of Representatives, 71st Congress, 2nd Session, Report No. 966, Mar. 24, 1930.

"Assassinated Dictator Somoza Buried in Miami Friday." Associated Press, Sep. 20, 1980.

"Aviator Killed in Midair Collision; Howard Gill Hurled 200 Feet to Ground in Crash at Chicago Meet." New York Times, Sep. 15, 1912.

“Bryan Home Nearly Completed.” Miami Daily Metropolis, Apr. 11, 1913.

"Bush Ally Harbored Plane-Bomb Suspect." Miami Herald, Sep. 5, 1988.

"Commemorating the Anniversary of the Inauguration of Air-Mail Service." United States House of Representatives, 78th Congress, 1st Session, Report No. 408, May 4. 1943.

"Concrete Homes at Ocean Beach, FLA." The Concrete Age, Jan. 1915, 12.

"Contract Air Mail Service." United States Senate, 68th Congress, 2nd Session, Report No. 864, Jan. 24, 1925.

"Contracts for Transportation of Mail by Air." United States House of Representatives, 70th Congress, 2nd Session, Report No. 2330, Feb. 1, 1929.

“Coral Gables Facts.” Miami, FL: Coral Gables Sales Corporation, Apr. 1927.

“Cuba..Progress Report.” The White House, Jul. 12, 1963, DNSA.

"Cuba Coordinating Committee - Progress Report." The White House, Jan. 17, 1963, DNSA.

"Cuban Exiles' Proposed Meeting with President Somoza." United States Department of State, Mar. 30, 1970, Declassified Nov. 10, 2003, DNSA.

"Cuban Focal Point in the Miami Area." The White House, Dec. 29, 1962. Sanitized and Declassified Aug. 9, 1984, DNSA.

"Cumpleaños 90 del Fundador de Diario Las Américas." Diario Las Américas, Apr. 22, 2015. 
“Curtiss Flying School.” Aeronautics, Vol. 10, No. 1 (Jan., 1912): 12, 19.

"Dangerous Dialogue: Attacks on Freedom of Expression in Miami's Cuban Exile Community." Americas Watch, Vol. 4, Issue 7 (Aug. 1992).

"Dangerous Dialogue Revisited: Threats to Freedom of Expression Continue in Miami's Cuban Exile Community." Americas Watch, Vol. 6, No. 14 (Nov. 1994).

“El Jardin.” Historical Preservation Report of City of Miami, Dec. 14, 1982.

"Fidel Castro Denounces Aggressions Against Cuba." The Black Scholar, Vol. 8, No. 3 (Dec., 1976): 10-17.

"FinCEN Takes Aim at Real Estate Secrecy in Manhattan and Miami." Press Release, Jan. 13, 2016, United States Department of the Treasury - Financial Crimes Enforcement Network.

"Florida Playground Merrymaking Mecca." Miami Herald, Jan. 28, 1934.

"Florida Population of Counties by Decennial Census: 1900 to 1990." Compiled and edited by Richard L. Forstall. Washington, DC: US Bureau of the Census, 1995.

“Forty Bombings This Year.” Miami News, Oct. 11, 1968.

“Full Text of President Coolidge's Address.” New York Times, Jan. 17, 1928, 2.

"Havana Students Scorn Mediation: Exile Group in Miami Says It Won't Deal with 'Executioners and Assassins'." New York Times, Jul. 15, 1933, N2.

"Hurricane Hits Miami.” Miami Daily News and Metropolis, Sep. 18, 1926.

"LaGuardia Irked by News of Plans: Considers Flying to Miami to Escape Reporters - Decides to Go On to Panama.” New York Times, Nov. 15, 1933.

"Lay Cornerstone of Miami University." New York Times, Feb. 5, 1926.

“Menocal Assails Our Cuba Policy.” New York Times, Jul. 5, 1933, 13.

“Miami of the Future Edition.” Miami Daily News, Jun. 10, 1934.

"Miami-Dade Aviation: Facts at a Glance." www.miami-airport.com/facts.asp.

"Miami International Airport, U.S. and World Airport Rankings, Passengers and Flights, 2014." Miami, FL: Miami-Dade Aviation Department - Marketing Division, 2015. 
“Millions of Capital Drawn to Miami.” New York Times, Mar. 15, 1925, 1-2.

"Pay of Carriers for Contract Ail Mail Service." United States House of Representatives, 69th Congress, 1st Session, Report No. 1197, May 6, 1926.

"Pilots, Companies and Other Individuals Working for Companies Used to Support the Contra Program." In Allegations of Connections Between CIA and The Contras in Cocaine Trafficking to the United States, Vol. 2 The Contra Story. Washington, DC: Office of Inspector General, 1996.

"Plymouth Congregational Church." Historical Preservation Report of City of Miami, Nov. 19, 1982.

"Presidios de Carlos y Cabo de los Martires." Sept. 2, 1569, made by Rodrigo Carreño, notary, and given by Pedro Menéndez Marques. Archivo General de Indios, Cuaderno 941, No. 5, Cuentos de Pedro Menéndez Marques. Copied and deposited at Charlton W. Tebeau Research Library, HistoryMiami, MS Box 39.

"Preventing the Spread of Yellow Fever Through Air Traffic." Public Health Reports, Vol. 52, No. 31 (Jun. 30, 1937): 1027-1030.

"The Promotion of Commercial Aviation." United States Senate, 69th Congress, 1st Session, Report No. 2, Dec. 14, 1925.

“Rebels in Florida Hold Back.” New York Times, Jun. 23, 1933, 7.

"Report on Accion Cubana (Cuban Action) (AC)." Federal Bureau of Investigation, Jun. 29, 1976, declassified Oct. 1, 1997, DNSA.

"Report on Comite Pro Gobierno de Cuba En El Exilio (Committee for a Cuban Government in Exile)." Federal Bureau of Investigation, Apr. 25, 1975, declassified Apr. 21, 1999, DNSA.

"Rubber Production in Liberia: An Exploratory Assessment of Living and Working Conditions, with Special Attention to Forced Labor." Verité (2010).

"SEC Sifts Profits in Florida's Boom.” New York Times, Sep. 17, 1935, 33.

"Some Attractive Homes of Well Known People." The Architect and Engineer of California, Vol. 50, No. 1 (1917): 63-64.

"Statement for the Record, FBI Director Robert S. Mueller, III." Sep. 26, 2002, at Joint Intelligence Committee Inquiry, http://fas.org/irp/congress/2002_hr/092602mueller.html. 
"Transcriptions of The Homeseeker: A Monthly Publication of the Model Land Company.” Introduced by Patrick Scott. Broward Legacy, Vol. 29, No. 1 (2009): 4-21.

"Villa Serena." Historic Preservation Report of City of Miami, Dec. 4, 2007.

"'Vizcaya,' the Villa and Grounds: A House at Miami, Florida." The

Architectural Review, Vol. 5, No. 7 (Jul., 1917): 121-167.

"Yellow Fever Control: U.S. Health Service Watches Miami Clipper Port." Life, May 27, 1940, 41-42.

Secondary Sources

Abreu, Christina D. Rhythms of Race: Cuban Musicians and the Making of Latino New York City and Miami, 1940-1960. Chapel Hill, NC: University of North Carolina Press, 2015.

Adelman, Jeremy, and Stephen Aron. "From Borderlands to Borders: Empires, Nation-States, and the Peoples in Between in North American History." Forum Essay, American Historical Review, Vol. 104, No. 3 (Jun., 1999): 814-841.

Adey, Peter. "'Ten Thousand Lads with Shining Eyes Are Dreaming and Their Dreams Are Wings': Affect, Airmindedness and the Birth of the Aerial Subject." Cultural Geographies, Vol. 18, No. 1 (Jan., 2011): 63-89.

Akin, Edward W. "The Cleveland Connection: Revelations from the John D. Rockefeller - Julia D. Tuttle Correspondence." Tequesta, Vol. 42 (1982): 57-61.

Altman, Ida. Emigrants and Society: Extremadura and America in the Sixteenth Century Berkeley, CA: University of California Press, 1989.

Alvarez, Robert R. Mangos, Chiles, and Truckers: The Business of

Transnationalism. Minneapolis, MN: University of Minnesota Press, 2005.

Alvarez, Robert R. "The March of Empire: Mangos, Avocados, and the Politics of Transfer." Gastronomica, Vol. 7, No. 2 (2007): 28-33.

Ammidown, Margot. "Walter DeGarmo: Fantasies in Concrete." Update, Vol. 11, No. 1 (Feb. 1984): 3-6.

Ansbacher, Sidney F., and Joe Knetsch. "Negotiating the Maze: Tracing Historical Title Claims in Spanish Land Grants and Swamp and Overflowed Lands Act." Journal of Land Use \& Environmental Law, Vol. 17, No. 2 (Spr., 2002): 351-373. 
Arguelles, Lourdes. "Cuban Miami: The Roots, Development, and Everyday Life of Emigré Enclave in the U.S. National Security State." Contemporary Marxism, No. 5 (Sum., 1982): 27-43.

Aron, Stephen. "Returning the West to the World." OAH Magazine of History, Vol. 20, No. 2 (Mar., 2006): 53-60.

Atwood, Anthony D. “A State of War: Florida from 1939 to 1945." PhD diss., Florida International University, 2012.

Beer, Gillian. "The Island and the Aeroplane: The Case of Virginia Woolf." In Nation and Narration, edited by Homi K. Bhabha, 265-290. New York: Routledge, 1990.

Bemis, Samuel Flagg. Pinckney's Treaty: America's Advantage from Europe's Distress, 1783-1800. Westport, CT: Praeger, 1960.

Berlin, Ira. Many Thousands Gone: The First Two Centuries of Slavery in North America. Cambridge, MA: Harvard University Press, 1998.

Beverley, John, and David Houston. "Notes on Miami." boundary 2, Vol. 23, No. 2 (Sum., 1996): 19-46.

Bilstein, Roger E. Flight in America: From the Wrights to the Astronauts. Baltimore, MD: Johns Hopkins University Press, 2001.

Blight, James G., and Philip Brenner. Sad and Luminous Days: Cuba's Struggle with the Superpowers after the Missile Crisis. Lanham, MD: Rowman and Littlefield, 2007.

Bolton, Herbert. "The Epic of Greater America." American Historical Review, Vol. 38, No. 3 (Apr., 1933): 448-474.

Boyer, M. Christine. "Aviation and the Aerial View: Le Corbusier's Spatial Transformations in the 1930s and 1940s." Diacritics, Vol. 33, No. 3/4 (Aut.-Win., 2003): 93-116.

Brooks, Philip Coolidge. Diplomacy and the Borderlands: The Adams-Onis Treaty of 1819. Berkeley, CA: University of California Press, 1939.

Brooks, Philip Coolidge, and Felix Calleja. "Pichardo's Treatise and the AdamsOnís Treaty." Hispanic American Historical Review, Vol. 15, No. 1 (Feb., 1935): 94-99. 
Brooks, Philip Coolidge. "Spain's Farewell to Louisiana, 1803-1821." The

Mississippi Valley Historical Review, Vol. 27, No. 1 (Jun., 1940): 27-41.

Brown, Jr., William E. "Pan Am: Miami's Wings to the World." Journal of Decorative and Propaganda Arts, Vol. 23 (1998): 144-161.

Brown, Jr., William E., and Karen Hudson. "Henry Flagler and the Model Land Company." Tequesta, Vol. 56 (1996) 44-78.

Bucheli, Marcelo. Bananas and Business: The United Fruit Company in Colombia, 1899-2000. New York: New York University Press, 2005.

Burbank, Jane, and Frederick Cooper. Empires in World History: Power and the Politics of Difference. Princeton, NJ: Princeton University Press, 2011.

Bush, Gregory W. "'Playground of the USA': Miami and the Promotion of Spectacle." Pacific Historical Review, Vol. 68, No. 2, Orange Empires Issue (May, 1999): 153-172.

Bushnell, Amy Turner. The King's Coffer: Proprietors of the Spanish Florida Treasury, 1565-1702. Gainesville, FL: University of Florida Press, 1981.

Bushnell, Amy Turner. "How to Fight a Pirate: Provincials, Royalists, and the Defense of Minor Ports during the Age of Buccaneers." Gulf Coast Historical Review, Vol. 5, No. 2 (1990): 18-35.

Campbell, Carl W. "Minor Tropical Fruit Cultivars in Florida." Florida Agricultural Experiment Stations Journal, Series No. 3724 (1970): 353-356.

Campbell, Carl W., and Robert J. Knight, Jr. "The Kromes, Pioneers in the Tropical Fruit Industry of Florida." Proceedings of the Florida State Horticultural Society, Vol. 111 (1998): 294-295.

Cañizares-Esguerra, Jorge. How to Write the History of the New World: Histories, Epistemologies, and Identities in the Eighteenth-Century Atlantic World. Palo Alto, CA: Stanford University Press, 2002.

Cañizares-Esguerra, Jorge. Nature, Empire, and Nation: Explorations of the History of Science in the Iberian World. Palo Alto, CA: Stanford University Press, 2006.

Carr, Robert S. "Majority Opinion on the Miami Circle." Archaeology, Vol. 52, No. 6 (Nov.-Dec., 1999): 10-11.

Carter, Kaye Edwards. Henry Perrine: Plant Pioneer of the Florida Frontier. Lake Buena Vista, FL: Tailored Tours, 1998. 
Casavantes Bradford, Anita. The Revolution is for the Children: The Politics of Childhood in Havana and Miami, 1959-1962. Chapel Hill, NC: University of North Carolina Press, 2014.

Castonguay, Stéphanie. "Creating an Agricultural World Order: Regional Plant Protection Problems and International Phytopathology, 1878-1939." Agricultural History, Vol. 84, No. 1 (Win., 2010): 46-73.

Chang, Kornel S. Pacific Connections: The Making of a U.S.-Canadian Borderlands. Berkeley, CA: University of California Press, 2012.

Chardon, Roland E. "The Cape Florida Society of 1773." Tequesta, Vol. 35 (1975): 1-36.

City and Society in Colonial Latin America, edited by Louisa Schell Hoberman and Susan Migden Socolow. Albuquerque, NM: University of New Mexico Press, 1986.

Coates, Peter. American Perceptions of Immigrant and Invasive Species:

Strangers on the Land. Berkeley, CA: University of California Press, 2007.

Cocks, Catherine. "The Pleasures of Degeneration: Climate, Race, and the Origins of the Global Tourist South in the Americas." Discourse, Vol. 29, No. 2 \& 3 (Spr. and Fall 2007): 215-235.

Colonial Crucible: Empire in the Making of the American State, edited by Alfred W. McCoy and Francisco A. Scarano. Madison, WI: University of Wisconsin Press, 2009.

Coloniality at Large: Latin America and the Postcolonial Debate, edited by Mabel Moraña, Enrique Dussel, and Carlos A. Jáuregui. Durham, NC: Duke University Press, 2008.

A Companion to the American West, edited by William Deverell. Maiden, MA: Blackwell, 2004.

Connolly, N.D.B. A World More Concrete: Real Estate and the Remaking of Jim Crow South Florida. Chicago, IL: University of Chicago Press, 2014.

Connolly, N.D.B. "By Eminent Domain: Race and Capital in the Building of an American South Florida.” PhD diss., University of Michigan, 2008.

Contested Ground: Frontiers on the Northern and Southern Edges of the Spanish Empire, edited by Donna J. Guy and Thomas E. Sheridan. Tuscon, AZ: University of Arizona Press, 1998. 
Coronil, Fernando. "Beyond Occidentalism: Toward Nonimperial Geohistorical Categories." Cultural Anthropology Vol. 11, No. 2 (Feb. 1996): 51-87.

Courtwright, David T. Sky as Frontier: Adventure, Aviation, and Empire. College Station, TX: Texas A\&M University Press, 2005.

Covington, James W. "Migration of the Seminoles into Florida, 1700-1820." Florida Historical Quarterly, Vol. 46, No. 4 (Apr., 1968): 340-357.

Crosby, Alfred J. The Columbian Exchange: Biological and Cultural Consequences of 1492. Wesport, CT: Greenwood, 1972.

Crosby, Alfred J. Ecological Imperialism: The Biological Expansion of Europe 900-1900. New York: Cambridge University Press, 2004.

Cuban Exiles in the United States, edited by Carlos E. Cortés. New York: Arno Press, Inc., 1980.

Cubberly, Frederick. "John Quincy Adams and Florida.” Florida Historical Quarterly, Vol. 5, No. 2 (Oct., 1926): 88-93.

Cullather, Nicholas. Operation PBSUCCESS: The United States and Guatemala, 1952-1954. Washington, DC: Central Intelligence Agency, 1994. Sanitized and declassified by CIA Historical Review Program, 1997.

Culot, Maurice, and Jean-Francois LeJeune. Miami: Architecture of the Tropics. New York: Princeton Architectural Press, 1993.

Curl, Donald W. "The Florida Architecture of F. Burrall Hoffman Jr., 18821980.” Florida Historical Quarterly, 76 (1998): 399-416.

Davis, Aurora E. "The Development of the Major Commercial Airlines in Dade County, Florida: 1945-1970.” Tequesta, Vol. 32 (1972): 3-16.

de la Torre, Miguel A. La Lucha for Cuba: Religion and Politics on the Streets of Miami. Berkeley, CA: University of California Press, 2003.

de los Angeles Torres, María. In the Land of Mirrors: Cuban Exile Politics in the United States. Ann Arbor, MI: The University of Michigan Press, 1999.

Dean, Warren. Brazil and the Struggle for Rubber. Cambridge, UK: Cambridge University Press, 1987. 
Deverell, William. Whitewashed Adobe: The Rise of Los Angeles and the Remaking of its Mexican Past. Berkeley, CA: University of California Press, 2005.

Díaz, María Elena. The Virgin, the King, and the Royal Slaves of El Cobre: Negotiating Freedom in Colonial Cuba, 1670-1780. Palo Alto, CA: Stanford University Press, 2001.

Dobson, Alan P. "The Other Air Battle: The American Pursuit of Post-War Civil Aviation Rights." The Historical Journal, Vol. 28, No. 2 (Jun., 1985): 429-439.

Domínguez, Jorge I. To Make the World Safe for Revolution: Cuba's Foreign Policy. Cambridge, MA: Harvard University Press, 2009.

Doty, Franklin A. "Florida, Iowa, and the National 'Balance of Power,' 1845." Florida Historical Quarterly, Vol. 35, No. 1 (Jul., 1956): 30-59.

Douglas, Ann. "Skyscrapers, Airplanes, and Airmindedness: 'The Necessary Angel'." In The Jazz Cadence of American Culture, edited by Robert G.

O’Meally, 196-224. New York: Columbia University Press, 1998.

Duany, Jorge. Blurred Borders: Transnational Migration between the Hispanic Caribbean and the United States. Chapel Hill, NC: University of North Carolina Press, 2011.

Dunlop, Beth. "Inventing Antiquity: The Art and Craft of Mediterranean Revival Architecture." The Journal of Decorative and Propaganda Arts, Vol. 23, Florida Theme Issue (1998): 190-207.

Dunn, Marvin. Black Miami in the Twentieth Century. Gainesville, FL: University Press of Florida, 1997.

Dunn, Marvin. “A Snub for the Ages.” Transitions, Vol. 116, Nelson Rolihlahla Mandela, 1918-2013 (2014): 98-105.

Eckstein, Susan Eva. The Immigrant Divide: How Cuban-Americans Changed the U.S. and their Homeland. New York: Routledge, 2009.

Engel, Jeffrey A. Cold War at 30,000 Feet: The Anglo-American Fight for Aviation Supremacy. Cambridge, MA: Harvard University Press, 2007.

Ewe, Sharon M.L., et al. "Foreign Exploration for Biological Control Agents of Three Invasive Plant Species from Asia.” Wildland Weeds (Fall, 2006): 19-21.

Filling in the Gaps: Ten Strategies to Strengthen Invasive Species Management in Florida. Washington, D.C.: Environmental Law Institute, 2004. 
Finlay, Mark J. Growing American Rubber: Strategic Plants and the Politics of National Security. New Brunswick, NJ: Rutgers University Press, 2013.

Foglesong, Richard E. Planning the Capitalist City: The Colonial Era to the 1920s. Princeton, NJ: Princeton University Press, 1986.

Ford, Worthington Chauncey. John Quincy Adams: His Connection with the Monroe Doctrine. Cambridge, MA: J. Wilson, 1902.

Forment, Carlos A. "Political Practice and the Rise of an Ethnic Enclave: The Cuban American Case, 1959-1979." Theory and Society, Vol. 18, No. 1 (Jan., 1989): 47-81.

Friedman, Andrew. Covert Capital: Landscapes of Denial and the Making of U.S. Empire in the Suburbs of Northern Virginia. Berkeley, CA: University of California Press, 2013.

Friedman, Max Paul. Nazis and Good Neighbors: The United States Campaign Against the Germans in Latin America in World War II. New York: Cambridge University Press, 2003.

Fritzsche, Peter. "Machine Dreams: Airmindedness and the Reinvention of Germany." American Historical Review, Vol. 98, No. 3 (Jun., 1993): 685-709.

Garcia, Maria Cristina. Havana USA: Cubans and Cuban Americans in South Florida, 1959-1994. Berkeley, CA: University of California Press, 1997.

Gaulin, Kenneth. "The Flying Boats: Pioneering Days to South America." Journal of Decorative and Propaganda Arts, Vol. 15 (Win.-Spr., 1990): 78-95.

Gelabert-Navia, José A. "American Architects in Cuba: 1900-1930." Journal of Decorative and Propaganda Arts, Vol. 22, Cuba Theme Issue (1996): 132-149.

George, Paul S. "Brokers, Binders, and Builders: Greater Miami's Boom of the Mid-1920s.” Florida Historical Quarterly, 65 (Jul., 1986): 27-51.

Gleijeses, Piero. Shattered Hope: The Guatemalan Revolution and the United States, 1944-1954. Princeton, NJ: Princeton University Press, 1992.

Gleijeses, Piero. "Ships in the Night: The CIA, the White House and the Bay of Pigs.” Journal of Latin American Studies, Vol. 27, No. 1 (Feb. 1995): 1-42.

Globalization and the Decolonial Option, edited by Walter D. Mignolo and Arturo Escobar. New York: Routledge, 2010. 
Gomez, Laura E. Manifest Destinies: The Making of the Mexican American Race. New York: New York University Press, 2008.

Gootenberg, Paul. Andean Cocaine: The Making of a Global Drug. Chapel Hill, NC: University of North Carolina Press, 2008.

Gould, Eliga H. "Entangled Histories, Entangled Worlds: The English-Speaking Atlantic as a Spanish Periphery." Forum Essay, American Historical Review, Vol. 112, No. 3 (Jun., 2007): 764-786.

Grandin, Greg. The Blood of Guatemala: A History of Race and Nation. Durham, NC: Duke University Press, 2000.

Grandin, Greg. Empire's Workshop: Latin America, the United States, and the Rise of the New Imperialism. New York: Metropolitan Books, 2006.

Grandin, Greg. Fordlandia: The Rise and Fall of Henry Ford's Forgotten Jungle City. New York: Picador, 2009.

Grenier, Guillermo J., and Max Castro. "Blacks and Cubans in Miami: The Negative Consequences of the Cuban Enclave on Ethnic Relations." In Governing American Cities: Inter-Ethnic Coalitions, Competition, and Conflict, edited by Michael Jones-Correa, 137-157. New York: Russel Sage Foundation, 2001.

Griesbach, R.J. 150 Years of Research at the United States Department of Agriculture: Plant Introduction and Breeding. Beltsville, MD: USDA Agricultural Research Service, 2013.

Gronbeck-Tedesco, John A. Cuba, the United States, and Cultures of the Transnational Left, 1930-1975. New York: Cambridge University Press, 2015.

Grosfoguel, Ramón. "World Cities in the Caribbean: The Rise of Miami and San Juan.” Review (Fernand Braudel Center), Vol. 17, No. 3 (Sum., 1994): 351-381.

Hach, Steve. Cold War in South Florida: Historical Resource Study. Atlanta, GA: Department of Interior - National Parks Service, 2004.

Hagedorn, Dan. Conquistadors of the Sky: A History of Aviation in Latin America. Gainesville, FL: University Press of Florida, 2008.

Haney, Patrick J., and Walt Vanderbush. The Cuban Embargo: The Domestic Politics of an American Foreign Policy. Pittsburgh, PA: University of Pittsburgh Press, 2005.

Hann, John H. Indians of Central and South Florida, 1513-1763. Gainesville, FL: University Press of Florida, 2003. 
Harp, Stephen L. A History of World Rubber: Empire, Industry, and the Everyday. New York: Wiley-Blackwell, 2015.

Harper, Paula. "Cuba Connections: Key West, Tampa, and Miami, 1870 to 1945." Journal of Decorative and Propaganda Arts, Vol. 22 (1996): 278-291.

Harris, Amanda. Fruits of Eden: David Fairchild and America's Plant Hunters. Gainesville, FL: University Press of Florida, 2015.

Hatton, Hap. Tropical Splendor: An Architectural History of Florida. New York: Alfred A. Knopf, 1987.

Hawes, Robert Winston. "The Empire of Pan American Airways.” MBA Thesis, Boston University, 1943.

Hillyer, Reiko. "The New South in the Ancient City: Flagler's St. Augustine Hotels and Sectional Reconciliation." Journal of Decorative and Propaganda Arts, Vol. 25, The American Hotel (2005): 104-135.

Hine, Robert V., and John Mack Faragher. The American West: A New Interpretive History. New Haven, CT: Yale University Press, 2000.

Hoffman, Joel M. "From Augustine to Tangerine: Florida at the U.S. World's Fairs." Journal of Decorative and Propaganda Arts, Vol. 23, Florida Theme Issue (1998): 48-85.

Hoffman, Paul E. The Spanish Crown and the Defense of the Caribbean, 15351585: Precedent, Patrimonialism, and Royal Parsimony. Baton Rouge, LA: Louisiana State University Press, 1980.

Hollander, Gail M. Raising Cane in the 'Glades: The Global Sugar Trade and the Transformation of Florida. Chicago, IL: University of Chicago Press, 2008.

Holloway, Thomas H. "Latin America: What's in a Name?" Adapted from his introductory essay in A Companion to Latin American History. Waltham, MA: Wiley/Blackwell, 2008.

Howard, Rosalyn. Black Seminoles in the Bahamas. Gainesville, FL: University of Florida Press, 2002.

hUallachain, Breandán Ó. "Foreign Banking in the American Urban System of Financial Organization.” Economic Geography, Vol. 70, No. 3 (Jul., 1994): 206228. 
Hurston, Zora Neale. "Florida's Migrant Farm Labor." Frontiers: A Journal of Women Studies, Vol. 12, No. 1 (1991): 199-203.

Immerman, Richard H. The CIA in Guatemala: The Foreign Policy of Intervention. Austin, TX: University of Texas Press, 1982.

Johnson, Howard. "Bahamian Labor Migration to Florida in the Late Nineteenth and Early Twentieth Centuries." International Migration Review, Vol. 22, No. 1 (Spr., 1988): 84-103.

Johnson, Sherry. The Social Transformation of Eighteenth-Century Cuba. Gainesville, FL: University Press of Florida, 2001.

Josephson, Matthew. Empire of the Air: Juan Trippe and the Struggle for World Airways. New York: Arno Press, 1972.

Kagan, Richard. Urban Images of the Hispanic World, 1493-1793. New Haven, CT: Yale University Press, 2000.

Kagan, Richard L. "Prescott's Paradigm: American Historical Scholarship and the Decline of Spain." American Historical Review, Vol. 101, No. 2 (Apr., 1996): 423-446.

Keegan, William F. The People Who Discovered Columbus: The Prehistory of the Bahamas. Gainesville, FL: University of Florida Press, 1992.

Kerber, Stephen. "Florida and the World's Columbian Exposition of 1893." Florida Historical Quarterly, 66 (Jul., 1987): 25-49.

Klein, Kerwin Lee. Frontiers of Historical Imagination: Narrating the European Conquest of Native America, 1890-1990. Berkeley, CA: University of California Press, 1997.

Knetsch, Joe, and Paul S. George. "A Problematical Law: The Armed Occupation Act of 1842 and Its Impact on Southeast Florida." Tequesta, Vol. 53 (1993): 6380.

Knight, Jr., Robert J., and Raymond J. Schnell. "Mango Introduction in Florida and the 'Haden' Cultivar's Significance to the Modern Industry." Economic Botany, Vol. 48, No. 2 (1994): 139-145.

Kornbluh, Peter. Bay of Pigs Declassified: The Secret CIA Report on the Invasion of Cuba. New York: New Press, 1998. 
Kramer, Paul A. "Power and Connection: Imperial Histories of the United States in the World." Review Essay, American Historical Review, Vol. 116 (2011): 1348-1391.

La Plante, Leah. “The Sage of Biscayne Bay: Charles Torrey Simpson's Love Affair with South Florida.” Tequesta, Vol. 55 (1995): 61-82.

Landau, Saul. “No Mas Canosa.” Monthly Review, Vol. 50, No. 10 (1999).

Landers, Jane G. Black Society in Spanish Florida. Urbana, IL: University of Illinois Press, 1999.

Landers, Jane G. "An Eighteenth-Century Community in Exile: The 'Floridanos' in Cuba." New West Indian Guide, Vol. 70, No. 1/2 (1996): 39-58.

Landers, Jane G. "Black Community and Culture in the Southeastern Borderlands." Journal of the Early Republic, Vol. 18, No. 1 (Spr., 1998): 117134.

Lane, Kris. Pillaging the Empire: Piracy in the Americas, 1500-1750. Armonk, NY: M.E. Sharpe, 1998.

Lawrence, George H. M. "A Bibliography of the Writings of David Fairchild." Huntia, Vol. 1 (Apr. 15, 1964): 79-102.

Lazarus, William C. Wings in the Sun: The Annals of Aviation in Florida. Orlando, FL: Tyn Cobb's Florida Press, 1951.

Leach Carson, Ruby. “Miami: 1896-1900.” Tequesta, Vol. 16 (1956): 3-13.

LeFeber, Walter. The New Empire: An Interpretation of American Expansion, 1860-1898. Ithaca, NY: Cornell University Press, 1963.

LeoGrande, William M., and Peter Kornbluh. Back Channel to Cuba: The Hidden History of Negotiations Between Washington and Havana. Chapel Hill, NC: University of North Carolina Press, 2015.

Levine, Barry B. “The Capital of Latin America." Wilson Quarterly, Vol. 9, No. 5 (Win., 1985): 46-69.

Linebaugh, Peter, and Marcus Rediker. The Many-Headed Hydra: Sailors, Slaves, Commoners, and the Hidden History of the Revolutionary Atlantic. London:

Verso, 2000.

Livingston, Grant. "The Annexation of the City of Coconut Grove." Tequesta, Vol. 60 (2000): 32-55. 
Lockhart, James. The Nahuas After Conquest: A Social and Cultural History of the Indians of Central Mexico, Sixteenth through the Eighteenth Centuries. Palo Alto, CA: Stanford University Press, 1994.

Lozano, Jose M. "The Last Eclectics: Walter DeGarmo and Richard Kiehnel in South Florida." Southeastern College Art Conference Review (1990): 363-371.

Macfie, David. "Richmond Naval Air Station, 1942-1961.” Tequesta, Vol. 37 (1977): 38-50.

Mackle, Elliott. "Two-Way Stretch: Some Dichotomies in the Advertising of Florida as the Boom Collapsed." Tequesta, Vol. 33 (1973): 17-29.

Maingot, Anthony P. "Laundering the Gains of the Drug Trade: Miami and Caribbean Tax Havens." Journal of Interamerican Studies and World Affairs, Vol. 30, No. 2/3 (Sum.-Aut., 1988): 167-187.

Marichal, Carlos. A Century of Debt Crises in Latin America: From Independence to the Great Depression, 1820-1930. Princeton, NJ: Princeton University Press, 1989.

Marks, Henry S. “A Forgotten Spanish Land Grant in South Florida.” Tequesta, Vol. 20 (1960): 51-55.

McCook, Stuart. "The Neo-Columbian Exchange: The Second Conquest of the Greater Caribbean, 1720-1930." Latin American Research Review, Vol. 46, Special Issue: Contemporary Debates on Ecology, Society, and Culture in Latin America (2011): 11-31.

McGrath, John T. The French in Early Florida: In the Eye of the Hurricane. Gainesville, FL: University Press of Florida, 2000.

McGuire, Raymond G. "Chapman Field - The Evolution of a South Dade Army Airdrome." Tequesta, Vol. 51 (2001): 58-85.

McNicoll, Robert E. "The Caloosa Village Tequesta: A Miami of the Sixteenth Century." Tequesta, Vol. 1, No. 2 (1941): 11-20.

Merleaux, April. Sugar and Civilization: American Empire and the Cultural Politics of Sweetness. Chapel Hill, NC: University of North Carolina Press, 2015.

Merrell, James H. “The Indians' New World: The Catawba Experience.” William and Mary Quarterly, Third Series, Vol. 41, Issue 4 (Oct., 1984): 537-565. 
Merrill, Dennis. Negotiating Paradise: U.S. Tourism and Empire in TwentiethCentury Latin America. Chapel Hill, NC: University of North Carolina Press, 2009.

Mickelson, Joan. "Pioneer Architect Leaves Mark on City." Broward Legacy, Vol. 26, No. 1 (2006): 17-25.

Mignolo, Walter D. The Darker Side of the Renaissance: Literacy, Territoriality, and Colonization. Ann Arbor, MI: University of Michigan Press, 2003.

Milanich, Jerald T. "Much Ado About a Circle." Archaeology, Vol. 52, No. 5 (Sept.-Oct., 1999): 22-25.

Miller Lane, Barbara. Houses for a New World: Builders and Buyers in American Suburbs, 1945-1965. Princeton, NJ: Princeton University Press, 2015.

Mirabent, Isabell Coll. Charles Deering and Ramón Casas: A Friendship in Art. Evanston, IL: Northwestern University Press, 2012.

Mohl, Raymond A. South of the South: Jewish Activists and the Civil Rights Movement in Miami, 1945-1960. Gainesville, FL: University Press of Florida, 2004.

Mohl, Raymond A. "Black Immigrants: Bahamians in Early Twentieth-Century Miami." Florida Historical Quarterly, Vol. 65, No. 3 (Jan. 1987): 271-297.

Mohl, Raymond A. "Changing Economic Patterns in the Miami Metropolitan Area, 1940-1980.” Tequesta, Vol. 42 (1982): 63-73.

Mohl, Raymond A. "Shadows in the Sunshine: Race and Ethnicity in Miami." Tequesta, Vol. 49 (1989): 63-80.

Mohl, Raymond A. "On the Edge: Blacks and Hispanics in Metropolitan Miami since 1959.” Florida Historical Quarterly, Vol. 69 (Jul., 1990): 37-56.

Mohl, Raymond A. "The Origins of Miami’s Liberty City." Florida Environmental and Urban Issues, Vol. 12 (Jul., 1985): 9-12.

Mohl, Raymond A. "Whitening Miami: Race, Housing, and Government Policy in Twentieth-Century Dade County." Florida Historical Quarterly, Vol. 79, No. 3 (Win., 2001): 319-345.

Mormino, Gary R. "Midas Returns: Miami Goes to War, 1941-1945.” Tequesta, Vol. 57 (1997): 5-51. 
Morrissey, Siobhan. "A Circle Kept Unbroken: Eminent Domain Saves Rare U.S. Archaeological Site." American Bar Association Journal, Vol. 86, No. 8 (Aug., 2000): 24-25.

Morse, Richard M. "A Prolegomenon to Latin American Urban History."

Hispanic American Historical Review, Vol. 52, No. 3 (Aug., 1972): 359-394.

Morse, Richard M. "Latin American Cities: Aspects of Function and Structure." Comparative Studies in Society and History, Vol. 4, No. 4 (Jul., 1962): 473-493.

Morse, Richard M. "Some Characteristics of Latin American Urban History." American Historical Review, Vol. 67, No. 2 (Jan., 1962): 317-338.

Morton, Julia F. "No One Loves the Bischofia Anymore." Proceedings of the Florida State Horticultural Society, Vol. 97 (1984): 241-244.

Morton, Julia F. "Pestiferous Spread of Many Ornamental and Fruit Species in South Florida." Proceedings of Florida State Horticultural Society, Vol. 89 (1978): 348-353.

Mumford, Lewis. The City in History: Its Origins, Its Transformations, and Its Prospects. New York: Harvest, 1961.

Nash, Philip. The Other Missiles of October: Eisenhower, Kennedy, and the Jupiters, 1957-1963. Chapel Hill: University of North Carolina Press, 1997.

Navarrete, Jeanine. "From Refugees to Model Minorities: Cuban-Americans and the Media in Miami, 1960-1970." PhD diss., University of North Carolina-Chapel Hill, 2013.

Nelson, Richard Alan. "Palm Trees, Public Relations, and Promoters: Boosting Florida as a Motion Picture Empire, 1910-1930." Florida Historical Quarterly, Vol. 61, No. 4 (Apr., 1983): 383-403.

Nelson Limerick, Patricia. The Legacy of Conquest: The Unbroken Past of the American West. New York: W.W. Norton, 1987.

Ngai, Mae. Impossible Subjects: Illegal Aliens and the Making of Modern America. Princeton, NJ: Princeton University Press, 2004.

Ogren Rothra, Elizabeth. Florida's Pioneer Naturalist: The Life of Charles Torrey Simpson. Gainesville, FL: University Press of Florida, 1995.

Okihiro, Gary Y. Pineapple Culture: A History of the Tropical and Temperate Zones. Berkeley, CA: University of California Press, 2009. 
Oltman Fink, Susan. "Politics and Prayer in West Perrine, Florida: Civic Social Capital and the Black Church." PhD diss., Florida International University, 2005.

Osorio, Alejandra B. Inventing Lima: Baroque Modernity in Peru's South Sea Metropolis. New York: Palgrave Macmillan, 2008.

Palmer, Scott W. "On Wings of Courage: Public 'Air-mindedness' and National Identity in Late Imperial Russia." The Russian Review, Vol. 54, No. 2 (Apr., 1995): 209-226.

Palmer, Scott W. "Peasants into Pilots: Soviet Air-Mindedness as an Ideology of Dominance." Technology and Culture, Vol. 41, No. 1 (Jan., 2000): 1-26.

Paquette, Gabriel B. Enlightenment, Governance, and Reform in Spain and its Empire, 1759-1808. London: Palgrave Macmillan, 2008.

Patricios, Nicholas N. Building Marvelous Miami. Gainesville, FL: University Press of Florida, 1994.

Patricios, Nicholas N. "Phineas Paist and the Architecture of Coral Gables, Florida." Tequesta, Vol. 64 (2004): 5-27.

Pauly, Philip. "The Beauty and Menace of the Japanese Cherry Trees: Conflicting Visions of American Ecological Independence.” Isis, Vol. 87 (1996): 51-73.

Pérez, Jr., Louis A. Cuba in the American Imagination: Metaphor and the Imperial Ethos. Chapel Hill, NC: University of North Carolina Press, 2008.

Pérez Jr., Louis A. On Becoming Cuban: Identity, Nationality and Culture. Chapel Hill, NC: University of North Carolina Press, 1999.

Pérez Jr., Louis A. "Between Encounter and Experience: Florida in the Cuban Imagination." Florida Historical Quarterly, Vol. 82, No. 2 (Fall, 2003): 170-190.

Perrine, Henry E. The True Story of Some Eventful Years in Grandpa's Life. Buffalo, NY: privately printed by author, 1885.

Pestana, Carla Gardina. "Early English Jamaica without Pirates." William and Mary Quarterly, Vol. 71, No. 3 (Jul., 2014): 321-360.

Peters, Thelma. “Miami’s First Plane.” Update, Vol. 12, No. 4 (Nov., 1985): 3-4.

Polyani, Karl. The Great Transformation: The Political and Economic Origins of Our Time. Boston: Beacon Press, 2001. 
Portes, Alejandro, and Alex Stepick. City On the Edge: The Transformation of Miami. Berkeley, CA: University of California Press, 1993.

Posada Carbó, Eduardo. The Colombian Caribbean: A Regional History, 18701950. New York: Oxford University Press, 1996.

The Progressive Era's Health Reform Movement: A Historical Dictionary. Westport, CT: Greenwood Publishing Group, 2003.

Provine, William B. Sewall Wright and Evolutionary Biology. Chicago, IL: University of Chicago Press, 1988.

Ravich, Timothy M. "Is Airline Passenger Profiling Necessary?” University of Miami Law Review, Vol. 62 (Oct., 2007): 1-57.

Redford, Polly. Billion-Dollar Sand Bar: A Biography of Miami Beach. Boston, MA: E.P.Dutton, 1970.

Rediker, Marcus. Between the Devil and the Deep Blue Sea: Merchant Seamen, Pirates, and the Anglo-American Maritime World, 1700-1750. Cambridge, UK: Cambridge University Press, 1987.

Rediker, Marcus. "'Under the Banner of King Death': The Social World of Anglo-American Pirates, 1716 to 1726." William and Mary Quarterly, Vol. 38, No. 2 (Apr., 1981): 203-227.

Renda, Mary A. Taking Haiti: Military Occupation and the Culture of U.S. Imperialism, 1915-1940. Chapel Hill, NC: University of North Carolina Press, 2001.

Rereading the Black Legend: The Discourses of Religious and Racial Difference in the Renaissance Empires, edited by Margaret R. Greer, Walter D. Mignolo, and Maureen Quilligan. Chicago, IL: University of Chicago Press, 2007.

Ridings, Amanda S. "Wings Over Miami." Update, Vol. 12, No. 4 (Nov., 1985): 8.

Rifkin, Mark. Manifesting America: The Imperial Construction of U.S. National Space. New York: Oxford University Press, 2012.

Robinson, T. Ralph. "Henry Perrine: Pioneer Horticulturalist of Florida." Tequesta, Vol. 1, No. 3 (1941): 16-24.

Roorda, Eric Paul. "The Cult of the Airplane among U.S. Military Men and Dominicans during the U.S. Occupation and the Trujillo Regime." In Close Encounters of Empire: Writing the Cultural History of U.S.-Latin American 
Relations, edited by Gilbert M. Joseph, Catherine C. LeGrand, and Ricardo D. Salvatore, 269-310. Durham, NC: Duke University Press, 1998.

Rose, Chanelle Nyree. The Struggle for Black Freedom in Miami: Civil Rights and America's Tourist Paradise, 1896-1968. Baton Rouge, LA: Louisiana State University Press, 2015.

Rose, Chanelle Nyree. "Neither Southern nor Northern: Miami, Florida and the Black Freedom Struggle in America's Tourist Paradise, 1896-1968." PhD diss., University of Miami, 2007.

Rose, Chanelle Nyree. "Tourism and the Hispanicization of Race in Jim Crow Miami, 1945-1965.” Journal of Social History, Vol. 45, No. 3 (Spr., 2012): 735756.

Rose, Harold M. "Metropolitan Miami's Changing Negro Population, 19501960.” Economic Geography, Vol. 40, No. 3 (Jul., 1964): 221-238.

Roseberry, Cecil R. Glenn Curtiss: Pioneer of Flight. Syracuse, NY: Syracuse University Press, 1972.

Rosenberg, Emily S. Financial Missionaries to the World: The Politics and Culture of Dollar Diplomacy, 1900-1930. Durham, NC: Duke University Press, 2004.

Rosengarten, Jr., Frederic. Wilson Popenoe: Agricultural Explorer, Educator, and Friend of Latin America. Lawai, HI: National Tropical Botanical Garden, 1991.

Sáenz Rovner, Eduardo. "Las Redes de Cubanos, Norteamericanos, y Colombianos en el Narcotráfico en Miami Durante los Años Sesenta." Innovar: Revista de Ciencias Administrativas y Sociales, Vol. 18, No. 32 (Jul.-Dec., 2008): 111-126.

Salvatore, Ricardo D. "Imperial Revisionism: US Historians of Latin America and the Spanish Colonial Empire (ca. 1915-1945)." Journal of Transnational American Studies, Vol. 5, No. 1 (2013).

Sassen, Saskia, and Alejandro Portes. "Miami: A New Global City?" Contemporary Sociology, Vol. 22, No. 4 (Jul., 1993): 471-477.

Schiebinger, Londa. Plants and Empire: Colonial Bioprospecting in the Atlantic World. Cambridge, MA: Harvard University Press, 2004.

Schroeder, Michael J. "Bandits and Blanket Thieves, Communists and Terrorists: The Politics of Naming Sandinistas in Nicaragua, 1927-36 and 1979-90." Third World Quarterly, Vol. 26, No. 1 (2005): 67-86. 
Schwartz, Rosalie. Flying Down to Rio: Hollywood, Tourists, and Yankee Clippers. College Station, TX: Texas A\&M University Press, 2004.

Schwartz, Stuart B. All Can Be Saved: Tolerance and Salvation in the Iberian Atlantic World. New Haven, CT: Yale University Press, 2009.

The Second Conquest of Latin America: Coffee, Henequen, and Oil during the Export Boom, 1850-1930, edited by Steven C. Topik and Allen Wells. Austin, TX: University of Texas Press, 1997.

Seeds and Sovereignty: The Use and Control of Plant Genetic Resources, edited by Jack R. Kloppenburg, Jr. Durham, NC: Duke University Press, 1988.

Sessa, Frank B. “Miami in 1926.” Tequesta, 16 (1956): 15-35.

Sexton, Jay. The Monroe Doctrine: Empire and Nation in Nineteenth-Century America. New York: Hill and Wang, 2011.

Shappee, Nathan D. "Fort Dallas and the Naval Depot on Key Biscayne, 18361926." Tequesta, Vol. 21 (1961): 13-40.

Shell-Weiss, Melanie. Coming to Miami: A Social History. Gainesville, FL: University Press of Florida, 2009.

Shell-Weiss, Melanie. "Coming North to the South: Migration, Labor and CityBuilding in Twentieth-Century Miami." Florida Historical Quarterly, Vol. 84, No. 1, Special H-Florida Issue: Florida History from Transnational Perspectives (Sum., 2005): 79-99.

Sicius, Francis J. "The Miami-Havana Connection: The First Seventy-Five Years." Tequesta, Vol. 58 (1998): 4-45.

Silverblatt, Irene. Modern Inquisitions: Peru and the Colonial Origins of the Civilized World. Durham, NC: Duke University Press, 2004.

Sinclair, John. "“The Hollywood of Latin America': Miami as Regional Center in Television Trade." Television \& New Media, Vol. 3, No. 4 (Aug., 2003): 211-229.

Soluri, John. Banana Cultures: Agriculture, Consumption, and Environmental Change in Honduras and the United States. Austin, TX: University of Texas Press, 2005.

Stagg, J.C.A. Borderlines in Borderlands: James Madison and the SpanishAmerican Frontier, 1776-1821. New Haven, CT: Yale University Press, 2009. 
Steinberg, Theodore. "Do-It-Yourself Deathscape: The Unnatural History of Natural Disaster in South Florida." Environmental History, Vol. 2, No. 4 (Oct., 1997): 414-438.

Stern, Alexandra Minna. Eugenic Nation: Faults and Frontiers of Better Breeding in America. Berkeley, CA: University of California Press, 2015.

Stern, Steve J., and Immanuel Wallerstein. Forum: "Feudalism, Capitalism, and The World System in the Perspective of Latin America," and Responses. American Historical Review, Vol. 93, No. 4 (Oct., 1988).

Strangers in Paradise: Impact and Management of Nonindigenous Species in Florida, edited by Daniel Simberloff, Donald C. Schmitz, and Tom C. Brown. Washington, DC: Island Press, 1997.

Stresnau, Frederic B. Florida, My Eden: Exotic and Native Plants for Use in Tropic and Subtropic Landscape. Port Salerno, FL: Florida Classics Books, 1986.

Sturtevant, William C. "Chakaika and the 'Spanish Indians': Documentary Sources Compared with Seminole Tradition.” Tequesta, Vol. 13 (1953): 35-73.

Taylor, Alan. American Colonies: The Settling of North America. New York: Penguin, 2002.

TePaske, John Jay. The Governorship of Spanish Florida, 1700-1763. Durham, NC: Duke University Press, 1963.

This Land Is Our Land: Immigrants And Power In Miami, edited by Alex Stepick, Guillermo J. Grenier, and Max Castro. Berkeley, CA: University of California Press, 2003.

Thomas, Hugh. Cuba: The Pursuit of Freedom. New York: Harper \& Row, 1971.

Thurner, Mark. History's Peru: The Poetics of Colonial and Postcolonial Historiography. Gainesville, FL: University Press of Florida, 2011.

Tindall, George B. "The Bubble in the Sun.” American Heritage (Aug. 1965): 7883.

Todorov, Tzvetan. The Conquest of America: The Question of the Other. Translated by Richard Howard. Norman, OK: University of Oklahoma Press, 1999.

Trachtenberg, Alan. The Incorporation of America: Culture and Society in the Gilded Age. New York: Hill \& Wang, 1982. 
Turner, Frederick Jackson. "The Significance of the Frontier in American History." American Historical Association, Annual Report for the Year 1893, 199-227. Washington, DC: Government Printing Office, 1894.

Tweed, Thomas A. "An Emerging Protestant Establishment: Religious Affiliation and Public Power on the Urban Frontier in Miami, 1896-1904." Church History, Vol. 64, No. 3 (Sep., 1995): 412-437.

Untaming the Frontier in Anthropology, Archaeology, and History, edited by Bradley J. Parker and Lars Rodseth. Tuscon, AZ: University of Arizona Press, 2005.

van der Linden, F. Robert. Airlines and Air Mail: The Post Office and the Birth of the Commercial Aviation Industry. Lexington, KY: University of Kentucky Press, 2002.

Van Vleck, Jenifer. Empire of the Air: Aviation and the American Ascendancy. Cambridge, MA: Harvard University Press, 2013.

Vickers, Raymond B. Panic in Paradise: Florida's Banking Crash of 1926. Tuscaloosa, AL: University of Alabama Press, 2007.

Visions of Empire: Voyages, Botany, and Representations of Nature, edited by David Philip Miller and Peter Hanns Reill. Cambridge, UK: Cambridge University Press, 1996.

Warren, Christopher L., John F. Stack, and John G. Corbett. "Minority Mobilization in an International City: Rivalry and Conflict in Miami." PS, Vol. 19, No. 3 (Sum., 1986): 626-634.

Weber, David J. Bárbaros: Spaniards and Their Savages in the Age of Enlightenment. New Haven: Yale University Press, 2005.

Weber, David J. The Spanish Frontier in North America. New Haven, CT: Yale University Press, 1992.

Wells, Allen. Yucatan's Gilded Age: Haciendas, Henequen, and International Harvester, 1860-1915. Albuquerque, NM: University of New Mexico Press, 1985.

Whatley, George C., and Sylvia Cook. "The East Florida Land Commission: A Study in Frustration." Florida Historical Quarterly, Vol. 50, No. 1 (Jun., 1971): $39-52$. 
White, Richard. The Middle Ground: Indians, Empires, and Republics in the Great Lakes Region, 1650-1815. Cambridge, UK: Cambridge University Press, 1991.

Wilhelm, Chris. "For the Birds: Challenging Wilderness in the Everglades." Journal of Environmental Studies and Sciences, Vol. 3, No. 2 (Jun., 2013): 153166.

Wilhelm, Chris. "Prophet of the Glades: Ernest Coe and the Fight for Everglades National Park." PhD diss., Florida State University, 2010.

Wilkins, Mira. Foreign Enterprise in Florida: The Impact of Non-U.S. Direct Investment. Miami, FL: Florida International University, 1979.

Wilkins, Mira. "Venezuelan Investment in Florida: 1979." Latin American Research Review, Vol. 16, No. 1 (1981): 156-165.

Williams, Linda K. "The School for Famous Flyers: Reminiscence of Charles Christian Witmer." Update, Vol. 12, No. 4 (Nov., 1985): 4-5.

Wilson, Brian C. Dr. John Kellogg and the Religion of Biologic Living. Bloomington, IN: Indiana University Press, 2014.

Wilson, Chris. The Myth of Making Santa Fe: Creating a Modern Regional Tradition. Albuquerque, NM: University of New Mexico Press, 1997.

Wohl, Robert. A Passion for Wings: Aviation and the Western Imagination, 19081918. New Haven, CT: Yale University Press, 1994.

Wurfel, Seymour W. “Aircraft Piracy - Crime or Fun?” William \& Mary Law Review, Vol. 10, No. 4 (1969): 820-873.

Yúdice, George. "Miami: Images of a Latinopolis." NACLA Report on the Americas (Nov.-Dec., 2005): 35-40. 
VITA

JOHN K. BABB

Born in Sioux Falls, South Dakota

ACADEMIC HISTORY

2005-2008

B.A. History, Spanish

Southern Oregon University

Ashland, Oregon

2009-2010

M.A. Social Science

University of Chicago

Chicago, Illinois

$2011-2014$

Graduate Teaching Assistant

Florida International University

Miami Florida

\section{PUBLICATIONS AND PRESENTATIONS}

Panel Chair, "Regulating Slavery in the Atlantic"

Florida International University Graduate Student Conference (April 4, 2014)

Paper Presentation, "The Viceroyalty of Miami: An Introduction"

Stony Brook University Latin American and Caribbean Studies Graduate Student Conference (April 25, 2014)

Book Review, Anita Casavantes Bradford, "The Revolution is for the Children: The Politics of Childhood in Havana and Miami, 1959-1962," The Journal of the History of Childhood and Youth, Vol. 8, No. 2 (Spring 2015): 333-334.

Paper Presentation, "Growing Tropical Miami," Florida Conference of Historians Annual Meeting, University of Central Florida (Feb. 20, 2016) 